\title{
Engenharia civil: Inovação e Sustentabilidade
}

\section{ORGANIZADORES}

FABRICIO DE AMORIM RODRIGUES

SARA SANTARÉM

SUELANIA CRISTINA GONZAGA DE FIGUEIREDO 
Fabrício de Amorim Rodrigues

Sara Santarém

Suelania Cristina Gonzaga de Figueiredo

(Organizadores)

\section{Engenharia civil: Inovação e Sustentabilidade}

1a Ediçao

Belo Horizonte

Poisson

2020 
Editor Chefe: Dr. Darly Fernando Andrade

\section{Conselho Editorial}

Dr. Antônio Artur de Souza - Universidade Federal de

Minas Gerais Msc. Davilson Eduardo Andrade

Dra. Elizângela de Jesus Oliveira - Universidade Federal do

Amazonas Msc. Fabiane dos Santos

Dr. José Eduardo Ferreira Lopes - Universidade Federal de Uberlândia

Dr. Otaviano Francisco Neves - Pucminas

Dr. Luiz Cláudio de Lima - Universidade FUMEC

Dr. Nelson Ferreira Filho - Faculdades Kennedy

Msc. Valdiney Alves de Oliveira - Universidade Federal de Uberlândia

\section{Conselho Científico}

Dra. Fabiana Rocha Pinto

Esp. Frank Henrique Santos Fontineles

Me. Igor Bezerra de Lima

Me. Livia da Silva Oliveira

Dra Luciane Farias Ribas

Me. Sara dos Santos Santarém

Dra Samantha Coelho Pinheiro

\begin{tabular}{|l} 
Eados Internacionais de Catalogação na Publicação (CIP) \\
E57 Engenharia Civil: Inovação e Sustentabilidade/ Organizadores: Fabrício de Amorim \\
Rodrigues, Sara Santarém, Suelania Cristina Gonzaga de Figueiredo - MG: \\
Poisson, 2020 \\
Formato: PDF \\
ISBN: 978-65-5866-023-1 \\
DOI: 10.36229/978-65-5866-023-1 \\
Modo de acesso: World Wide Web \\
Inclui bibliografia \\
1. Engenharia 2 Sustentabilidade 3. Inovação I. RODRIGUES, Fabrício de \\
Amorim. II. SANTARÉM, Sara III. FIGUEIREDO, Suelania Cristina Gonzada de IV. Título \\
Sônia Márcia Soares de Moura - CRB 6/1896 \\
\hline
\end{tabular}

O conteúdo dos artigos e seus dados em sua forma, correção e confiabilidade são de responsabilidade exclusiva dos seus respectivos autores.

www.poisson.com.br

contato@poisson.com.br 


\section{EQUIPE ORGANIZADORA}

\section{FABRÍCIO DE AMORIM RODRIGUES}

Possui graduação em Engenharia Civil pela Universidade do Estado do Amazonas (2008) e mestrado em Engenharia Civil pela Universidade Federal do Amazonas (2015). E atualmente coordena do curso de Engenharia Civil do Centro Universitário Fametro.

\section{SARA SANTARÉM}

Mestre em engenharia civil pela Universidade Federal do Amazonas (2018) e Bacharela em Engenharia Civil (2015) pela Universidade Nilton Lins. Docente no Centro Universitário FAMETRO para o curso de Engenharia Civil. Experiência na área de Gestão, planejamento e controle, Orçamento, Projetos e Execução. Cerificação em inglês Avançado (2019) pela Minds idiomas e possui experiência nos sistemas SAP, RM, UAU e SP7. Habilidades com Planilhas em Excel e MS Project e negociação com fornecedores,gerenciamento de equipes.

\section{SUELANIA CRISTINA GONZAGA DE FIGUEIREDO}

Possui graduação em Economia, mestrado em Desenvolvimento Regional e doutorado em Ciências da Educação. Atualmente é Coordenadora de Pesquisa e Extensão do Instituto Metropolitano de Ensino _ IME, atuando principalmente nos seguintes temas: Sustentabilidade, Pesquisa, Iniciação Cientifica, Articulação entre Pesquisa, Ensino e Extensão. 


\section{PREFÁCIO}

Na área de engenharia civil há uma diversidade de temas que contribuem para a formação do profissional. 0 conhecimento desses temas fica por muitas vezes limitado pelo tempo de conclusão do curso de graduação. A lacuna deixada pelo conhecimento mais sedimentado de determinados temas é preenchida pelo trabalho de conclusão de curso.

0 trabalho de conclusão de curso para o estudante de engenharia é a oportunidade de aprofundamento em um tema de seu interesse. 0 tema escolhido pelo graduando, que na maioria dos casos está concluindo o curso, é o possível campo de atuação profissional. A elaboração do trabalho de conclusão de curso proporciona ao estudante maior imersão no tema escolhido, desenvolvendo habilidades de leitura, escrita, síntese e análise.

A pesquisa sobre o tema permite ao graduando o contato com a literatura acadêmica, a qual possui uma linguagem técnica muito própria de cada tema. Essa linguagem técnica da escrita acadêmica desenvolve no estudante a capacidade de transmitir conhecimento com qualidade. Portanto, promover uma coletânea dos trabalhos de conclusão de curso de engenharia civil é uma forma de divulgar esses trabalhos, e assim incentivar novos trabalhos.

Entre os temas escolhidos pelos alunos de graduação do curso de engenharia civil foram selecionados trabalhos sobre concepção de projetos comerciais para a construção civil, o uso de metodologias para gestão de obras como BIM (Building Information Modeling) e Lean Construction, analise de estabilidade talude, técnicas construtivas como paredes de concreto, concretos permeáveis e argamassas com vidro, georreferenciamento para gestão de resíduos e impacto de obras inacabadas.

Essa publicação representa todo o conhecimento adquirido a respeito de temas que vem sendo foco de debate na área de engenharia civil. E espera-se estar contribuindo para desenvolvimento de outras publicações nos temas ou ainda encorajar os estudantes de engenharia civil a buscar esses conhecimentos e desenvolver novos temas. Que as abordagens dos temas desta publicação abram portas para novas publicações ainda mais inovadoras, tal como a área de engenharia civil deve ser.

Manaus, 06 de Novembro de 2020

Prof. a Dr. - Luciane Farias Ribas Centro Universitário Fametro 


\title{
SUMÁRIO
}

CAPÍTULO 1: COMPLEXO DE SERVIÇOS PARA A CONSTRUÇÃo CIVIL E O MERCADO IMOBILIÁRIO

08

ANDRÉ FARIAS RIBAS

DANIEL MONTENEGRO ALFAIA

LUCIANE FARIAS RIBAS

DOI: 10.36229/978-65-5866-023-1.CAP.01

CAPÍTULO 2: BIM 8D: ESTUDO DE CASO DA AVALIAÇÃO DE RISCO NO ALMOXARIFADO DO CANTEIRO DE OBRAS.

\author{
GLEICE ANA DA FonsECA \\ LUCIANE FARIAS RIBAS \\ SARA SANTAREM \\ DOI: 10.36229/978-65-5866-023-1.CAP.02
}

CAPÍTULO 3: CONSTRUÇÃO ENXUTA E SEUS BENEFÍ́CIOS PARA A CONSTRUÇÃO CIVIL EM TEMPOS DE CRISE . .43

LEILA MACEDO DA SiLVA

BianCA GuimarẽEs PEDRosa

LUCIANE FARIAS RIBAS

SARA SANTAREM

DOI: 10.36229/978-65-5866-023-1.CAP.03

CAPÍTULO 4: ESTUDO DE RUPTURA EM TALUDE NA RUA ENCONTRO DAS ÁGUAS NO BAIRRO MAUAZINHO - MANAUS

LUANA SILVA DE SOUZA

NATHÁLIA AQUINO DE LIMA

LUCIANE FARIAS RIBAS

SARA SANTAREM

DOI: 10.36229/978-65-5866-023-1.CAP.04

CAPÍTULO 5: ESTUDO DE CASO DA EXECUÇÃO DE PAREDES DE CONCRETO PARA HABITAÇÃO DE BAIXA RENDA. .73

Manoel Oliveira de Albuquerque Junior

SARA DOS SANTOS SANTARÉM

LUCIANE FARIAS RIBAS

FRANK HENRIQUE SANTOS FONTINELES

DOI: 10.36229/978-65-5866-023-1.CAP.05

\section{CAPÍTULO 6: ANÁLISE COMPARATIVA ENTRE PISO CERÂMICO PRENSADO E PISO CERÂMICO} EXTRUDADO EM COZINHA INDUSTRIAL

LUCIMIR AZEVEDO MONTEIRO NETO

SARA DOS SANTOS SANTARÉM

LUCIANE FARIAS RIBAS

DOI: 10.36229/978-65-5866-023-1.CAP.06 


\title{
SUMÁRIO
}

CAPÍTULO 7: DESENVOLVIMENTO EXPERIMENTAL DO CONCRETO PERMEÁVEL COM SEIXO .... 104

Elane BatisTa de Almeida

ELISSANDRA BARATA DA SILVA

LUCIANE FARIAS RIBAS

SARA SANTAREM

DOI: 10.36229/978-65-5866-023-1.CAP.07

CAPÍTULO 8: ESTUDO DAS PROPRIEDADES MECÂNICAS DA ARGAMASSA COM RESÍDUO DE VIDRO TEMPERADO PARA REVESTIMENTO .121

\author{
Adenize Souza De CARVAlHo \\ ELIAS BELARMINO DA CRUZ LINS \\ LUCIANE FARIAS RIBAS \\ SARA SANTAREM \\ DOI: 10.36229/978-65-5866-023-1.CAP.08
}

CAPÍTULO 9:GEOREFERENCIAMENTO: PROPOSTA DE MAPEAMENTO DE RESÍDUOS DE CONSTRUÇÃO E DEMOLIÇÃO NA CIDADE DE MANAUS-AM

Duílio Wendell Rodrigues dos Reis

FABIANA ROCHA PINTO

LUCIANE FARIAS RIBAS

SARA SANTAREM

ELIZANDRO APARECIDO ROCHA DOS SANTOS

DOI: 10.36229/978-65-5866-023-1.CAP.09

CAPÍTULO 10: ANÁLISE DE RISCOS EM IMÓVEIS ENTORNO DE OBRAS INACABADAS: UM ESTUDO DE CASO NA CIDADE DE MANAUS-AM.

Matheus SouZa De Oliveira

ADRIANA SOUZA DE OLIVEIRA

LUCIANE FARIAS RIBAS

SARA SANTAREM

DOI: 10.36229/978-65-5866-023-1.CAP.10 


\title{
Capítulo 1
}

\section{Complexo de serviços para a construção civil e o mercado imobiliário}

\author{
André Farias Ribas
}

Daniel Montenegro Alfaia

Luciane Farias Ribas

Resumo: 0 mercado imobiliário há 10 anos atrás na cidade de Manaus crescia em ritmo acelerado. Surgia a necessidade de integração entre diversos serviços em um só lugar, principalmente os serviços relacionados a área da Construção Civil. Isso porque com o crescimento urbano, o tempo de deslocamento entre as diversas obras, que ocorriam naquele momento, e os pontos comerciais, que atendiam a essas obras, aumentou. No entanto, concentrar esses serviços em apenas um lugar exige um estudo detalhado quanto a localização e os impactos desse tipo de edificação no local. Esse tipo de edificação é de elevada complexidade do ponto de vista de elementos de projeto. Por essa razão o objetivo do presente trabalho é elaborar o projeto de um Complexo de Serviços para a Construção Civil e Mercado Imobiliário, a partir do estudo da localização e seus impactos no contexto urbano, buscando um projeto referência no segmento de edificações comerciais para os profissionais da arquitetura. 0 estudo se justifica por reunir serviços de uma atividade do setor da construção civil em um único complexo de forma a dinamizar as etapas garantindo um maior fluxo financeiro para o mercado. Além de atrair investimentos externos, destacando sua infra-estrutura e potencial econômico. 0 espaço busca ainda oferecer ambientes para palestras e cursos, intensificando o intercâmbio entre os profissionais locais. Com isso o empreendimento promoverá a integração entre os escritórios-empresas e as Instituições de Ensino incorporando a prática profissional ao cotidiano do estudante através de convênios e parcerias. 0 estudo partiu da escolha do local e da adequação ao contexto urbano visando mitigar os impactos causados pelo aumento do fluxo de atividades na edificação. A partir do estabelecimento dos serviços a serem oferecidos na edificação foram estabelecidas as áreas necessárias, a setorização e organização funcional. Com a definição das áreas e do fluxograma foram feitos os projetos preliminar, anteprojeto e executivo. Reunir todas as etapas em um único lugar facilita a logística dos serviços, diminui os prazos e aumenta o fluxo financeiro do setor. Desta forma o Complexo de Serviços surge como opção de dinamização de um setor que é responsável atualmente por uma parte significativa do promissor mercado imobiliário de Manaus.

Palavras-chave: complexo de serviços, mercado imobiliário, construção civil. 


\section{INTRODUÇÃO}

O crescimento do mercado imobiliário em Manaus impulsionou o desenvolvimento de vários campos de conhecimento. Atualmente, a demanda por profissionais da Construção Civil é crescente, as Instituições de Ensino formam cada vez mais Arquitetos e Urbanistas, Engenheiros Civis, Técnicos em Edificações, assim como diversos profissionais relacionados à área. 0 crescimento da Construção Civil e do Mercado Imobiliário segue em paralelo a evolução urbana da cidade de Manaus, a tendência pela verticalização dos residenciais multifamiliares, a necessidade de segurança oferecida pelos conjuntos habitacionais de médio a alto padrão e os diversificados empreendimentos de comércio e serviços recorrentes de novas empresas, exigem dinamismo nos prazos para atender a procura dos serviços, para que o fluxo financeiro torne-se cada vez maior. Para tanto, é necessário que haja um espaço em que todas as atividades pertinentes a elaboração, execução, complementação e regularização dos projetos sejam realizadas, proporcionando praticidade para os clientes e para os profissionais, oferecendo em um único lugar tudo que é relacionado à Construção Civil e o Mercado Imobiliário. Este empreendimento não busca somente ser um ponto de negócios, mas uma referencia estético-funcional, em alusão ao seu uso específico, seu público-alvo, os profissionais envolvidos no funcionamento e o desenvolvimento do espaço em questão, para que a Construção Civil seja difundida e acessível para todas as classes da sociedade. 0 complexo surge também para promover a integração dos diversos campos envolvidos em nas etapas de um projeto, seja qual for o seu tipo, uso, ou porte, estimulando a troca de conhecimentos e a complementação das competências pertinentes a cada área, estimulando o respeito mútuo, a união dos profissionais em prol do desenvolvimento da classe e a transmissão do legado aos futuros profissionais, que possam vir a ter um ambiente especialmente voltado para o uso da criatividade, arrojo e inovação, sempre em busca de uma identidade para a região, priorizando sempre os valores culturais, ecológicos e sociais da região amazônica. 0 projeto tem por objetivo elaborar o projeto de um Complexo de Serviços para a Construção Civil e Mercado Imobiliário, a partir do estudo da localização e seus impactos no contexto urbano, buscando um projeto referência no segmento de edificações comerciais para os profissionais da arquitetura.

\section{REFERENCIAL TEÓRICO}

\subsection{EVOLUÇÃO HISTÓRICA DOS EMPREENDIMENTOS COORPORATIVOS}

$\mathrm{O}$ ambiente administrativo de trabalho passou, no decorrer do século XX, por grandes transformações. Com a revolução industrial e posteriormente a ênfase nos processos de transporte virtual de dados e de comunicação, pautados na tecnologia da informação e no uso de computadores, as relações pessoatrabalho ampliam seus horizontes, deixando de se caracterizar como atividades geográficas e exclusivamente fixas (ANDRADE, 2007).

Quando se deu início à migração da mão-de-obra do campo para a cidade, por volta de 1800, atraída por um processo de desenvolvimento econômico que culminou com a revolução industrial. Pessoas deixaram o campo e foram para a cidade à procura de emprego na indústria e nos pequenos escritórios. 0 preço da terra elevou-se e encorajou seus proprietários a dividi-las em pequenos lotes, gerando uma grande densidade de edifícios no centro das cidades. A migração da mão-de-obra do campo para a indústria e da indústria para o escritório transformou a relação do homem com o trabalho nos últimos 100 anos. Do ponto de vista fisiológico, o homem deixou de exercer uma atividade ao ar livre, sujeita às intempéries, que exigia o uso da força e a movimentação física, e passou para uma atividade monótona e repetitiva na produção fabril, até tornar-se cada vez mais sedentário ao sentar-se no ambiente de trabalho de um escritório. Apesar de certas atividades típicas de escritórios existirem desde os primórdios das sociedades organizadas, é somente a partir do final do século XIX, com o crescimento da indústria, que se dá início ao grande crescimento das organizações e à estruturação dos escritórios tal qual como conhecemos hoje.

Os primeiros edifícios de escritórios eram feitos de alvenaria e só permitiam 10 pavimentos, para tanto as paredes possuíam $1,20 \mathrm{~m}$ de espessura, tornando os ambientes pequenos e economicamente desfavoráveis, assim eram compostos de pequenas salas não possuindo banheiros ou copas. Em 1860, surgem os pilares com armadura e ferro, vigas metálicas e o elevador de uso de passageiros pelas Otis Elevator Company. Em 1889 é construído o Edifício Leiter em Chicago, o primeiro com estrutura modulada tipo esqueleto e fachada em cortina de vidro. 0 desenvolvimento dos sistemas estruturais e do transporte vertical seguro trouxe os edifícios de escritório do século XX com fachadas de vidros moduladas e espaços únicos de pouca profundidade (15 a 20 metros) possibilitando o máximo de penetração de iluminação e ventilação natural. 0 desenvolvimento dos sistemas de ventilação mecânica, iluminação artificial e forros modulares acústicos permitiram a construção de grandes espaços internos 
dando origem aos arranha-céus que, ao longo século $\mathrm{XX}$, mantiveram a evolução de suas construções adotando pele de vidro nas fachadas, estruturas modulares em ferro e concreto e planta livre.

Na Europa o desenvolvimento dos prédios de escritórios não teve a mesma força, devido ao estilo arquitetônico consolidado na maioria das cidades européias. Em geral, os prédios eram destinados a usos específicos resultando em prédios mais baixos que os americanos e com partidos arquitetônicos diferenciados e localizados nos subúrbios ao invés da região central. Eram orgânicos e favoreciam a interação do usuário com o ambiente externo fazendo uso de iluminação e ventilação naturais. 0 diferencial dos europeus era a preocupação com o bem-estar do usuário, privilegiando a função e não a estética, ao contrário dos americanos que sempre viam seus prédios de escritórios como mercadorias.

No Brasil os prédios de escritórios surgem no começo do século XX com o advento do setor terciário proveniente de investimentos internacionais especialmente nas cidades de São Paulo e Rio de Janeiro. Com a vinda das multinacionais, essas empresas demonstravam seu poderio econômico em suas fachadas e intensificaram a construção de vários edifícios de escritórios no centro dessas cidades. Na década de 70, os edifícios começam a fazer uso dos avanços tecnológicos relacionados ao controle predial. 0 termo "edifícios inteligentes" surge na década de 80 para designar tão somente as construções que são concebidas de modo a fornecer conforto ambiental ao usuário por meio das novas tecnologias e que se adéqüem ao longo do tempo mantendo sua integridade oferecendo sempre qualidade térmica, acústica, visual e de materiais de acabamentos proporcionando ambientes amplos e circulações adequadas ao uso.

Atualmente os prédios de escritórios passam por transformações profundas em suas concepções de modo a favorecer o meio ambiente. Países do Norte da Europa manifestaram nos últimos anos a preocupação com o meio ambiente a busca de soluções sustentáveis usando a natureza como aliado na busca de um ambiente de qualidade com política de reciclagem de materiais e conservação de energia.

\subsection{EMPREENDIMENTOS EMBLEMÁTICOS - “CASES"}

Nesta secção serão apresentados "cases" de empreendimentos coorporativos considerados neste trabalho como emblematicos. 0 conceito dessas obras e os elementos construtivos foram referencias importantes para o seguimento de empreendimentos coorporativos há 10 anos atrás. Os empreendimentos são Tod's Omotesando Building (Japão) e Parque Alemanha (Brasil). Na cidade de Manaus, o Millennium Shopping Mall despontou como o maior complexo comercial da cidade. Nesta seção foi destacada a sua importância para a mudança do conceito de construção de empreendimentos coorporativos.

\subsubsection{INTERNACIONAL: TOD'S OMOTESANDO BUILDING - TÓQUIO, JAPÃO}

O Tod's Omotesando Building é um centro de compras localizado em Tóquio, capital do Japão. 0 projeto é do arquiteto japonês Toyo Ito e possui 7 pavimentos distribuídos em uma área construída de pouco mais de $400 \mathrm{~m}^{2}$. 0 estilo desconstrutivista prevalece na fachada que é composta de concreto reforçado e aço. 0 jogo de iluminação composto oferece efeitos distintos na presença e na ausência de luz natural, extraindo a rotina desta obra e dando a ela uma dupla identidade. 0 partido arquitetônico desconstrutivista é o ponto de referência a ser seguido por este empreendimento buscando identidade estética exigida pelo empreendimento voltado também ao mercado da Arquitetura e Urbanismo.

\subsubsection{NACIONAL: PARQUE ALEMANHA - PORTO ALEGRE-RS, BRASIL.}

O Programa Adote uma Praça foi implantado na cidade de Porto Alegre através da Lei Complementar Municipal 136/1986, estando ainda presente como político estatal por meio da Lei Complementar $618 / 2009$ e Decreto Municipal 14.539/2004. Trata-se de um programa em que pessoas jurídicas colaboram financeiramente na manutenção e na renovação de áreas públicas (praças, parques, canteiros, rótulas, monumentos), recebendo como compensação a possibilidade de fazer publicidade através da instalação de placas e/ou da promoção de eventos no local do investimento. Atualmente existem quatro parques, 71 praças, e 91 verdes complementares (como canteiros e rótulas) além de um trecho da orla do Guaíba com aproximadamente $13 \mathrm{~km}$ de extensão, que estão adotados. 0 Parque Alemanha foi construído pela iniciativa privada em 2006, resultado da medida compensatória que a empresa Goldsztein cumpriu pela construção de um grande loteamento voltado para a classe média, o Jardim Europa. No meio do loteamento está o parque, com uma área pública de 15 hectares. Localizado em uma área valorizada da cidade junto aos shoppings Iguatemi e Bourbon Country, o loteamento Jardim Europa trata-se de um 
empreendimento de grande vulto na região. A construtora aponta, inclusive, que o Jardim Europa é a construção de um novo bairro em Porto Alegre. Encravado no meio do loteamento está o Parque Alemanha, com a peculiaridade de ser o primeiro e único parque cercado da cidade de Porto Alegre. Esse cercamento provoca o fechamento do parque à noite (a área fica aberta das $6 \mathrm{~h}$ até às $20 \mathrm{~h}$ ). Além disso, a construtora disponibiliza uma equipe de segurança para atender o parque. Com isso, o controle sobre as atividades realizadas no parque se amplifica, de modo que a construtora não desvaloriza, por questões de insegurança, o empreendimento que realizou no entorno (SOUZA, 2010). No Complexo de Serviços pretende-se destinar um espaço voltado para o uso público, com o objetivo de requalificar o entorno imediato ao empreendimento, buscando valorização econômica e comercial, assim como se tornar referência em contribuição da iniciativa privada para o desenvolvimento do contexto urbano, despertando discussões em torno da necessidade de criação de instrumentos normativos, com o intuito de incorporar parâmetros urbanísticos como exigências na implantação de projetos de variados portes em troca de compensações em impostos e taxas.

\subsubsection{REGIONAL: MILLENNIUM SHOPPING MALL - MANAUS-AM, BRASIL.}

É um centro de serviço e comércio composto por embasamento com praça de alimentação, lojas e cinemas e três torres - Medical Tower, Business Tower e Centure Apart Service. Foi inaugurado em 2004 e foi o primeiro Complexo Misto com Torres na cidade atraindo o público de classe média, principalmente as classes A e B, para um novo ponto comercial e de serviços - consultórios médicos e odontológicos, hotéis e escritórios de negócios. 0 uso adotado pelo empreendimento é o ponto de partida para o Complexo de Serviços, incorporando as características de estrutura funcional para torre mista, combinando os usos de comércio e serviço distribuídos em torre e embasamento.

\section{METODOLOGIA}

O estudo foi realizado em 2011, e teve como localidade a cidade de Manaus, a qual no período apresentava um crescimento imobiliário expressivo. 0 estudo partiu da escolha do local e da adequação ao contexto urbano visando mitigar os impactos causados pelo aumento do fluxo de atividades na edificação. A partir do estabelecimento dos serviços a serem oferecidos na edificação foram estabelecidas as áreas necessárias, a setorização e organização funcional. Com a definição das áreas e do fluxograma foram feitos os projetos preliminar, anteprojeto e executivo.

\section{1. ÁREA DE INTERVENÇÃO E ESCOLHA DO LOCAL}

O terreno escolhido situava-se na Rua Pará, Conjunto Vieiralves, Bairro Nossa Senhora das Graças, Zona Centro-Sul da cidade de Manaus-AM. Limitava-se ao norte com a Rua Pará, a leste com a Avenida Rio Jutaí, ao sul com a Rua Rosa Cruz e a oeste com a Rua Rio Içá. O terreno possuía $7.070,71 \mathrm{~m}^{2}$ e possibilitava acessos por quatro vias. A escolha do terreno em questão se deu ao fato de estar localizado em uma das principais zonas de comércio e serviços da cidade de Manaus. Além disso, a Rua Pará era uma via coletora que recebia parte do fluxo da Av. Djalma Batista, Av. Constantino Nery e Av. São Jorge, sendo uma via de ligação entre a Zona Oeste e a Zona Leste e Sul, na época. A Rua Pará possuía um leito carroçável com três faixas de rolamento definidas e o fluxo de veículos não provocava engarrafamentos frequentes, sendo assim umas das poucas vias principais da cidade que não possuíam tantos problemas com o trânsito intenso e crescente da capital. 0 restante da quadra era composto por edificações residenciais de padrão baixo a médio em sua maioria.

\subsection{IMPACTOS NA CIDADE E ADEQUAÇÃO DO PROJETO AO CONTEXTO URBANO}

A transformações no entorno tanto de ordem ambiental como social foram consideradas para o cenário da época. Neste item são apresentados os possíveis impactos do empreendimento na cidade, considerando o cenário de 10 anos atrás. Como o complexo de serviços tem a tendência a incentivar o mercado imobiliário e da Construção Civil da cidade de Manaus, um aumento pela procura de profissionais da área é esperado. A concentração dos escritórios e empresas atrairá nova clientela proveniente da crescente classe média. 0 surgimento de feiras, congressos e eventos regionais de engenharia, arquitetura e urbanismo, bem como a vinda dos eventos nacionais e internacionais que podem transformar Manaus em um dos principais centros de encontro de profissionais acerca do potencial turístico da região, apelo ambiental e importância 
econômica de capital. A implantação de conceito estético-funcional para prédios de escritórios, difundindo o uso de materiais e técnicas construtivas que se adequem às condições ambientais de Manaus. 0 crescimento da representatividade econômica e comercial do Conjunto Vieiralves e expansão desta área de influência modificando a médio e longo prazo o uso no entrono, tornando predominante a zona comercial e de serviço em todo o território ocupado pelo conjunto. A intervenção a nível urbanístico no terreno em questão de forma a proporcionar um espaço público arborizado, sinalizado e acessível que possua mobiliários sirvam a população, buscando a requalificação do espaço e mostrando que a iniciativa privada é capaz de contribuir com o contexto urbano.

\subsection{ADEQUAÇÃO A LEGISLAÇÃO E NORMAS TÉCNICAS}

Para a adequação do empreendimento a legislação e normas técnicas foram utilizadas os seguintes documentos regulatórios e normativos: Lei №. 672/2002: Normas de Uso e Ocupação do Solo; Lei №. 673/2002: Código de Obras e Edificações; NBR 09077/2001 - Saídas de Emergência em Edifícios; NBR 13768/1997 - Porta Corta-Fogo de Emergência; Instrução Técnica № 11/2001 - Saídas de Emergência em Edificações; Instrução Técnica № 13/2001 - Pressurização de Escada de Segurança; NBR 09050/2004 Acessibilidade à Edificações, Mobiliário, Espaços e Equipamentos Urbanos; NBR 13994/2000 - Elevadores de Passageiros - Elevadores para Transportes de Pessoa Portadora de Deficiência; Lei no. 672/2002, Anexo III - Quadro de Intensidade de Ocupação por Unidade de Estruturação Urbana.

Conforme a Lei no. 672/2002, os parâmetros para a intensidade de ocupação da UES Vieiralves, na qual está inserido o local escolhido, para verticalização média são: CAMT máx. 4,8; Gabarito máx. 12 pavimentos; Testada Mínima para Verticalização 15 m; Taxa de Ocupação Máx. 50\%; Afastamento Mín. Frontal e Fundos 0,2 x H; Afastamento Mín. Laterais 0,25 x H. As Diretrizes e Parâmetros para Corredor Urbano Sul-Norte - Segmento Sul, para verticalização alta são: CAMT máx. 4,8; Gabarito máx. 18 pavimentos; Testada Mínima para Verticalização 15 m; Taxa de Ocupação Máx. 30\%; Afastamento Mín. Frontal e Fundos 0,2 x H; Afastamento Mín. Laterais 0,25 x H. De acordo com a Lei №. 672/2002, no Parágrafo Único do Art. 69. devem prevalecer os parâmetros estabelecidos para o maior gabarito, desta forma prevaleceu os parâmetros do Corredor Urbano Sul-Norte - Segmento Sul. Entretanto, a taxa de ocupação máxima é baixa, então faz-se uso do artigo 71 da Lei №. 672/2002, no Parágrafo Único, que diz: "A taxa de ocupação de edificações horizontais e do embasamento de edificações verticais, poderá extrapolar os valores dos (anexos III, IV e V), atendidos os afastamentos pertinentes aos números de pavimentos e a taxa de permeabilidade correspondente". Para tal, os afastamentos foram calculados conforme a altura útil da edificação - altura do segmento vertical medido ao meio da fachada e compreendido entre o nível da soleira do pavimento de acesso ao edifício, junto a fachada, e a linha horizontal, passando pelo ponto mais alto do edifício incluindo-se a caixa da escada, mas excluindo-se caixa d'água e caixa de máquinas - (Lei № 672 - Uso e Ocupação do Solo, 2002). Observando o Art. 80, que somente permite verticalização em lotes que estejam situados em vias ou logradouros com largura mínima de $11 \mathrm{~m}$ (onze metros). Conforme medição in loco, foi medida a caixa viária da Rua Pará, rua para a qual o lote faz frente, levando em consideração as distâncias entre os alinhamentos dos muros limítrofes. Foi encontrado o valor de 17,95m (Dezessete Metros e Noventa e Cinco Centímetros). Sendo assim está autorizada por lei a verticalização para este projeto, tendo em vista que o valor encontrado na medição excede em demasia o valor mínimo exigido.

A taxa de permeabilidade foi definida conforme a determinação do artigo 81 da Lei №. 672/2002, parágrafos 1,23 ou 4, considerando a área do lote escolhido para o projeto. 0 terreno em questão possui $7.070,71 \mathrm{~m}^{2}$ o que equivale a menos de $1 \mathrm{ha}$, desta forma o projeto se encaixa na exigência da taxa de permeabilidade de $15 \%$ de acordo com o parágrafo segundo do artigo 81 . Os usos definidos para o terreno em questão são definidos conforme o Anexo VII (Quadro de Usos e Atividades Por Corredor Urbano):

- Diretirzes: Predominância de usos comercial e de serviços, de expansão da área central, com estímulo a atividades não-geradoras de tráfego: tolerância par ao uso residencial em condicções adequadas.

- Usos Permitidos: Residencial unifamiliar e multifamiliar; comercial e de serviços; industrial.

- Atividades Permitidas: Atividades tipo 1, 2, 3 e 4.

Desta forma é permitida e incentivada a implantação do uso comercial e de serviços. 0 uso predominante se desmembra nos tipos de atividades relacionadas ao complexo, assim, classifica-se, de acordo com o Anexo X (Enquadramento das Atividades), os serviços a serem disponibilizados como: 
- TIPO 1: Compra e venda de imóveis próprios (6810-2/01), Corretagem na compra e venda de imóveis (6821-8/01), Serviços de arquitetura (7111-1/00), Serviços de engenharia (7112-0/00), Serviços de cartografia, topografia e geodésia (7119-7/01), Serviços de desenhos técnicos relacionados à arquitetura e engenharia (7119-7/03), Serviços de perícia técnica relacionadas a segurança do trabalho (7119-7/04), Atividades técnicas relacionadas à arquitetura e engenharia não-especificadas anteriormente (71197/99), Decoração de interiores (7410-2/02),

O número de vagas de estacionamento foi definido conforme a determinação do Anexo XI (Quadro de Vagas de Garagem e Estacionamento). De acordo com o cálculo do número de vagas de estacionamento e o enquadramento das respectivas atividades, foram calculadas 367 vagas. Sendo assim, conforme a disponibilidade espacial, as adequações projetuais e o crescimento do fluxo de pessoas, projeto foram locadas 401 vagas de estacionamento. De acordo com o previsto no artigo 81 da Lei №. 673/2002, foram previstas também vagas para Portadores de Necessidades Especiais. 0 projeto enquadrou-se no caso do parágrafo II, sendo assim foi previsto o número mínimo de 4 vagas para Portadores de Necessidades Especiais. Foram projetadas 12, sendo 4 vagas para cada pavimento de estacionamento. Ainda foram previstas 12 vagas para idosos, sendo 4 vagas para cada pavimento de estacionamento. Desta forma, 0 total de vagas de estacionamento para o projeto foi de 425. Ainda de acordo com a mesma lei, Art. 82, deverá existir a previsão de área para carga e descarga, dado o uso proposto. Foram projetadas 4 áreas de carga e descarga, sendo uma para a Agência Bancária, uma para a Agência dos Correios e duas para as Lojas e Estabelecimentos de Serviço previstos para o Complexo (lotérica, cartório, gráfica, livraria, salão de beleza e lojas).

\subsection{DADOS FÍSICOS E AMBIENTAIS}

\subsubsection{LEVANTAMENTO PLANI-ALTIMÉTRICO}

O terreno em questão está localizado em uma área com pouca variação altimétrica. De acordo com dados topográficos do local, possui uma variação de aproximadamente 5 metros de altura entre uma extremidade e outra, partindo da cota 45 no lado oeste a cota 50 no lado leste.

No sentido norte e sul percebe-se uma pequena variação decorrente da curva da cota 50 que oscila ao longo do terreno. No entanto, para implantação dos dois níveis de estacionamento subsolo, são necessárias movimentações de terra, conforme mostra a Figura 1.

Figura 1. Dados altimétricos

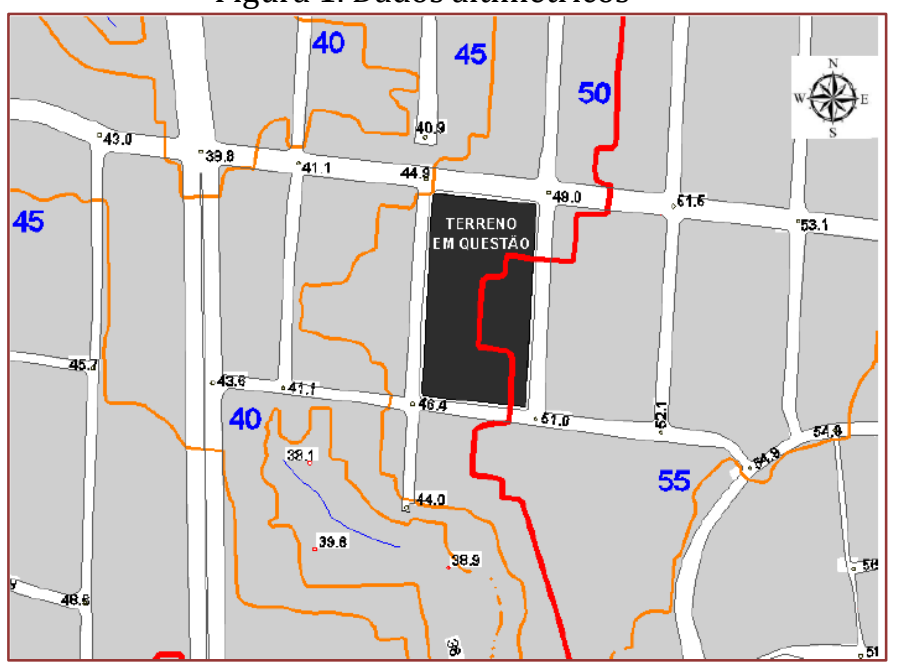

Buscando reduzir os gastos com as escavações, foram estudadas de forma a alterar o mínimo possível o terreno, apenas para locar as edificações e satisfazer as necessidades e exigências do projeto. 0 pavimento semi-enterrado e o pavimento subsolo 01 de estacionamentos poderão receber ventilação e iluminação naturais, reduzindo os gastos referentes a sistemas de refrigeração artificiais. Os dados planimétricos mostram um terreno retangular com lados opostos com medidas semelhantes, fator que irá facilitar a locação dos componentes do complexo a ser projetado. 


\subsubsection{VENTOS E RADIAÇÃO SOLAR INCIDENTE}

O terreno possui sua maior dimensão apontada para o sentido Norte-Sul, desta forma a radiação solar incidirá sobre as fachadas laterais. Na parte leste ocorrerá a incidência dos raios solares da manhã e pela parte da tarde os raios ocorrerão na fachada oeste.

Os ventos predominantes são provenientes do Nordeste, com pequena incidência dos ventos vindos de leste, de acordo com estudos geoclimáticos.

\subsubsection{SOMBRAS}

O sentido dos raios solares estudados no item anterior é mostrado na análise das sombras com os ângulos de incidência na parte da manhã, ao meio-dia e a tarde, conforme as Figuras 2 (a), (b) e (c).

Figura 2. Sombra (a) pela manhã; (b) ao meio dia e (c) pela tarde

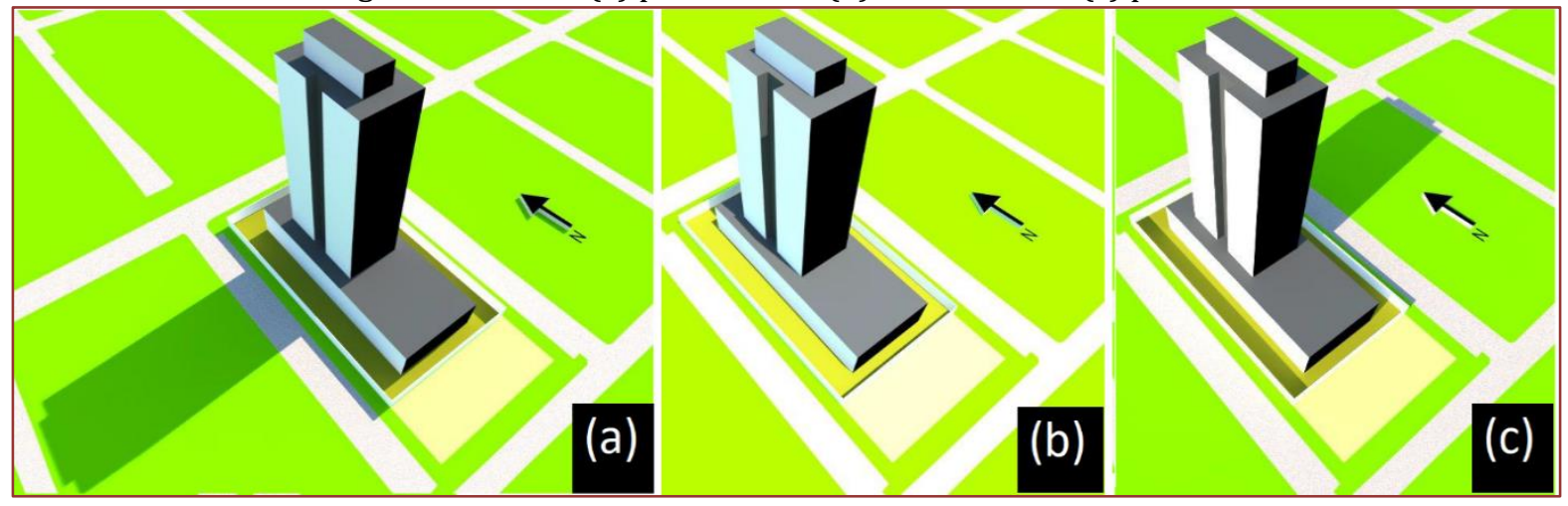

A partir do estudo das sombras, foi possível especificar quais materiais são mais adequados para cada fachada. As especificações a serem utilizadas foram embasadas na garantia da segurança quanto a perfeita empregabilidade dos componentes construtivos do projeto.

\subsubsection{VEGETAÇÃO EXISTENTE}

Existe pouca vegetação no entorno do terreno em questão, a intensa ocupação dos lotes e dos passeios públicos provocou, ao longo dos anos, o desparecimento das áreas verdes presentes na zona urbana de Manaus. Os "miolos de quadra" concentram a maior parte da massa vegetal preservada ainda na forma de árvores de médio e grande porte. Os passeios não são devidamente arborizados. Não existia, até a data deste estudo, legislação que obrigasse os empreendimentos a contribuírem para o crescimento da massa vegetal na cidade de Manaus. Desta forma, as ilhas de calor (concentração de calor proveniente do excesso de absorção da luz do dia por materiais como concreto, evitando a diminuição de temperatura na parte da noite) exercem grande influência sobre o entorno prejudicando a qualidade de vida da população.

\subsubsection{ESTUDO DO ENTORNO}

\section{ENTORNO IMEDIATO}

O entorno imediato à área de intervenção é diversificado, a mistura dos usos predominantes compõe um conjunto de edificações com usos que apoiam qualquer empreendimento a ser proposto.

A densa zona comercial e de serviço presente no entorno é composta por restaurantes, postos de gasolina, bancos, lojas de modulados, escritórios, consultórios, clínicas e ainda conta com alguns edifícios residenciais. 


\section{SISTEMA VIÁRIO - VIAS ARTERIAIS}

As vias principais são classificadas como arteriais, levando em conta as dimensões das caixas viárias e os seus respectivos fluxos, e estão próximas ao terreno em questão constituindo um papel importante no escoamento de fluxo viário para o empreendimento em questão.

A Avenida Djalma Batista possui mão-dupla e é uma das principais vias de ligação entre as Zonas Norte e Sul da cidade, seu fluxo é intenso e sobrecarregado e por vezes encontra-se engarrafada em "horários de pico", sobretudo quando há acidentes no local. A Avenida Constantino Nery desempenha a mesma função de sua via paralela.

\section{SISTEMA VIÁRIO - VIAS COLETORAS}

A Avenida João Valério abastece as vias arteriais acima citadas, o sentido de fluxo é leste-oeste e recebe tráfego da Rua Maceió e Avenida André Araújo, sua caixa viária é larga e favorece o recebimento de grande fluxo de veículos, porém com o crescimento do número de carros nas ruas de Manaus, esta alternativa já não é considerada suficiente para satisfazer as necessidades do tráfego. A Rua Pará possui o sentido de fluxo contrário à Avenida João Valério, recebe fluxo da Zona Oeste e parte do mesmo das vias arteriais e o redistribui em direção as Zonas Leste e Sul da cidade. Seu tráfego é intenso, porém não é a única opção de fluxo para as zonas acima citadas, não possuindo, desta forma, problemas tão graves de congestionamento quanto nas vias adjacentes.

\section{SISTEMA VIÁRIO - VIAS LOCAIS}

O Bairro Nossa Senhora das Graças é cortado pelas duas vias coletoras acima citadas, e seu interior é composto por diversas vias paralelas de caixa viárias e fluxo menores que as coletoras que dão o formato de malha retangular ao bairro, devido ás suas características de loteamento.

\subsubsection{LEVANTAMENTO FÍSICO-TERRITORIAL}

O levantamento físico-territorial foi realizado no dia 15.05.2011, seguindo os procedimentos realizados em experiências acadêmicas anteriores. Foi adotado um raio de 300 metros em torno do terreno em questão com o intuito de avaliar os usos predominantes no entorno, os gabaritos das edificações para avalição do impacto do número de pavimentos a serem empregados nos empreendimentos e as tipologias para obter o tipo de material mais usado nas edificações próximas.

\section{USO E OCUPAÇÃO DO SOLO}

Com o levantamento de uso e ocupação do solo efetuado, conclui-se a mistura predominante dos usos residencial e serviços. 0 uso misto com combinação de comércio e serviços também é denso, porém em menor quantidade que os anteriores. Encontram-se alguns terrenos vazios no entorno, possivelmente ainda a serem adquiridos para lançamentos de empreendimentos residenciais multifamiliares.

\section{GABARITO}

0 gabarito das edificações presentes no entorno é predominantemente térreo e de 2 pavimentos. As diretrizes e os parâmetros do Plano Diretor para esta área prevêem um incentivo à verticalização, porém este aspecto não está identificado nove anos após a implantação da lei.

As edificações continuam horizontais, na sua maioria térreas ou com 2 pavimentos, alguns prédios comerciais que abrigam escritórios e lojas térreas possuem 3 pavimentos, mas representam uma porcentagem muito baixa em relação ao todo, sendo ainda assim edificações horizontais de acordo com a lei. Os edifícios com 4 ou mais pavimentos consistem, na sua maioria, em prédios residenciais multifamiliares: empreendimentos que estão se tornando comuns na cidade. 


\section{TIPOLOGIA}

As tipologias das edificações são predominantemente de alvenaria. Esse aspecto pode ser notado em maior destaque no Conjunto Vieiralves, onde o padrão de acabamento e as tipologias das fachadas são mais elaboradas, visto o poder aquisitivo dos proprietários.

As edificações mistas com tipologias de alvenaria e madeira podem ser notadas nos arredores do antigo Beco do Macedo, mais precisamente no entorno da Rua Rosa Cruz, onde os padrões arquitetônicos não apresentam as mesmas características das ruas paralelas e o poder aquisitivo dos moradores não é tão elevado.

\subsection{PROGRAMA DE NECESSIDADES E DIMENSIONAMENTO}

Neste item foram definidos os espaços e as áreas necessárias, as quais foram divididas em: Subsolo 02; Subsolo 01; Estacionamento Semi-enterrado; Pavimento Térreo; Primeiro Pavimento; Segundo Pavimento; Pavimento Tipo 01 ( 1 andar); Pavimento Tipo 02 (4 andares); Pavimento Tipo 03 (3 andares); Pavimento Tipo 04 (6 andares); Pavimento Tipo 05 (1 andar); Pavimento Tipo 05 (Mezanino); Pavimento Tipo 06 (Restaurante); Cobertura; Área Externa.

\subsection{SETORIZAÇÃO E ORGANIZAÇÃO FUNCIONAL}

\subsubsection{ESTUDO DE MANCHA}

O estudo de manchas a seguir na Figura 4, é apresentado como são os setores que compõe o Complexo de Serviços. Nos passeios é prevista uma faixa de arborização com árvores de médio a grande porte com o objetivo de amenizar os efeitos das ilhas de calor e aumentar a concentração de massa vegetal, a fim de proporcionar conforto térmico para os transeuntes.

Figura 4. Estudo de mancha (Fonte: Orto-Foto 2011 - ArcGis 9.3)

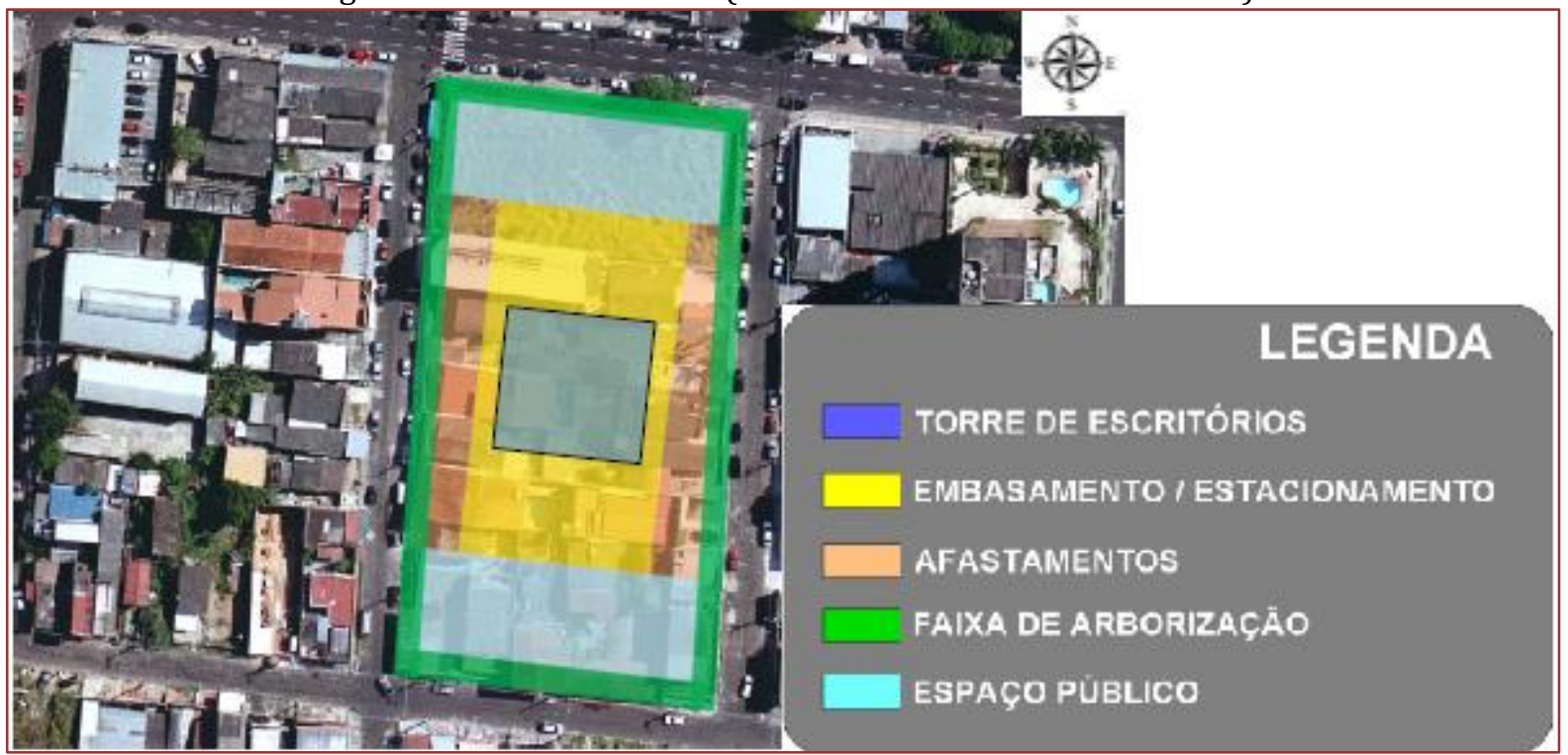

Os espaços públicos são destinados ao uso da população, sob cuidados da iniciativa privada e em parceria com o poder público. Na parte frontal, o complexo foi locado no centro do terreno, para que a paisagem do entorno fosse valorizada. Essa medida faz com que os imóveis da Rua Rio Iça e Av. Jutaí fiquem em evidência, tornando-os mais próximos da via principal (Rua Pará) e potencializando seu valor imobiliário. O espaço público, além de trazer uma nova opção de área de convivência para a cidade, proporciona um ambiente arborizado em meio a um movimentado centro comercial, incorporando uma paisagem natural ao ambiente urbano e dando conforto térmico a população, oferecendo mobilidade urbana. 0 espaço público na parte posterior do terreno tem por meta requalificar o trecho da Rua Rosa Cruz que apresenta padrões sócio-econômicos distintos do Conjunto Vieiralves. Agregado a esses setores é previsto o 
complexo em si, com os seus devidos afastamentos especificados em lei, composto por embasamento com 3 pavimentos, mais 3 pavimentos de estacionamento, sendo um semi-enterrado e 16 pavimentos-tipo para o torre. A torre estará localizada acima do embasamento com seus pavimentos devidamente implantados respeitando os parâmetros de afastamentos e taxas de ocupação previstos em lei.

\subsubsection{FLUXOGRAMA}

Neste item são apresentados os fluxogramas (Figura 5): Embasamento - Pavimento Térreo; Embasamento - Primeiro Pavimento e Embasamento - Segundo Pavimento e Torre.

Figura 5. Fluxogramas (a) Embasamento - Pavimento Térreo; (b) Embasamento - Primeiro Pavimento e (c) Embasamento - Segundo Pavimento e Torre.

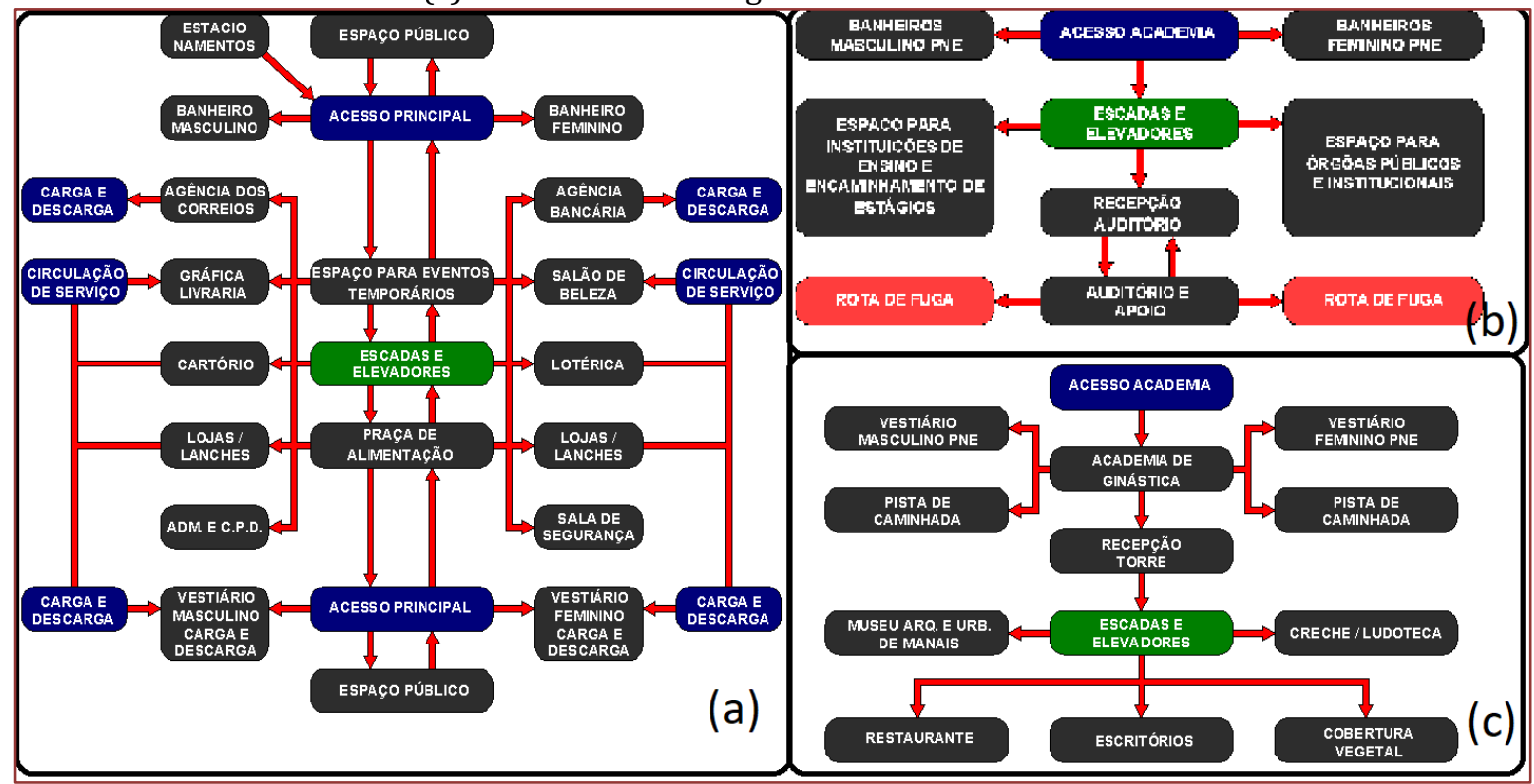

\subsection{PROJETO}

Com os estudos de localização, Setorização e organização funcional e foi possível fazer os projetos e seus componentes. Os projetos foram produzidos utilizando o programa SketchUp da Trimble . $_{\text {. }}$

\section{RESULTADOS}

\subsection{ESTUDO PRELIMINAR}

\subsubsection{IMPLANTAÇÃO}

A concepção da implantação se deu a partir do uso dos instrumentos normativos, visto os afastamentos pertinentes e previamente calculados para o terreno em questão. 0 embasamento está ocupando a parte central do terreno, deixando a parte frontal e posterior reservada para locação de espaço público. As laterais funcionam como afastamento lateral, assim como desempenham função de ventilação para os pavimentos subsolo 01 e semi-enterrado através dos taludes a serem feitos. A implantação pode ser visualizada na Figura 6. 
Figura 6. Implantação esquemática.

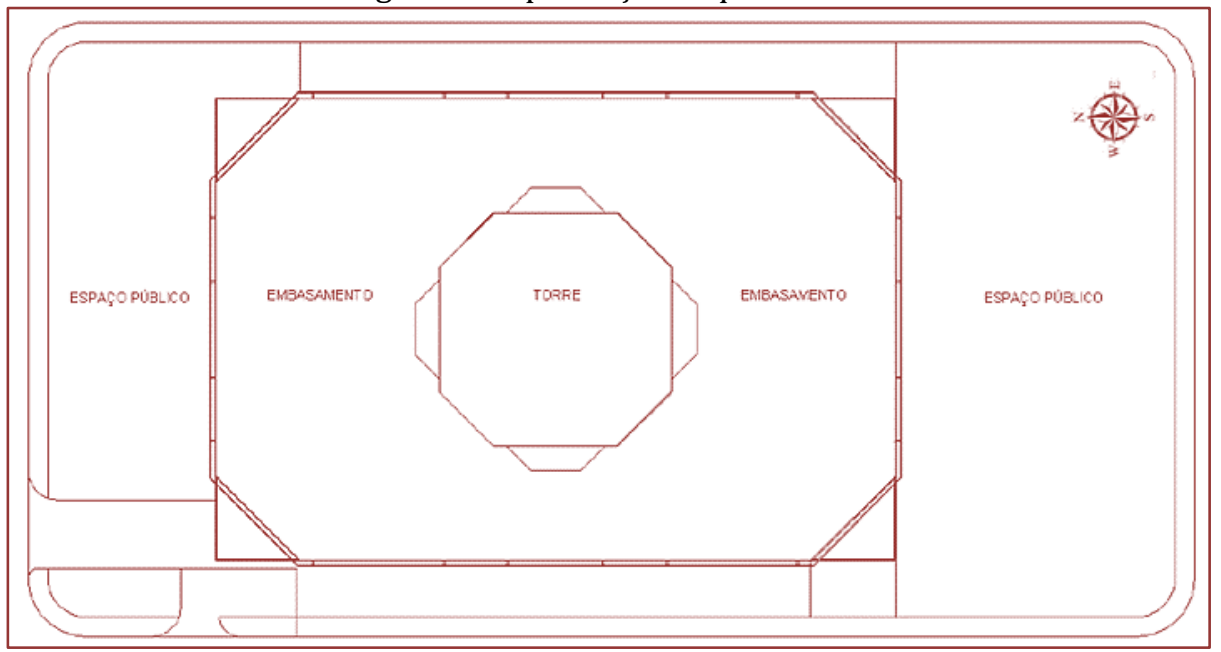

\subsubsection{PROPOSTA VOLUMÉTRICA DO EMBASAMENTO}

A proposta volumétrica do embasamento baseia-se em uma geometria octogonal, seguindo a forma retangular do terreno e respeitando seus devidos limites. Buscou-se uma simetria nas dimensões para melhor distribuição dos compartimentos internos e para aproveitamento pleno do lote, que possui uma área pequena para as pretensões do projeto. Devido a rigidez da forma do embasamento, surgiu a necessidade de suavizar seu aspecto, em busca de uma solução estética que trouxesse leveza a forma da base e ao mesmo tempo não causasse inquietação. 0 partido arquitetônico adotado é composto por uma "casca", com traçados curvos caracterizando elementos organicistas ao elemento construtivo. As cores claras foram implantadas ao elemento curvilíneo buscando contraste com as paredes escuras do embasamento, reforçando assim o efeito proposto. 0 conjunto "Casca-Embasamento" proporcionou um aspecto diferenciado ao partido arquitetônico, ao passo que as linhas orgânicas contrastam-se em relação a rigidez da forma da edificação, provocando um efeito equilibrado no conjunto arquitetônico, alcançando desta maneira a identidade arquitetônica pretendida pelo projeto. A Figura 7 ilustra a volumétrica do conjunto "Casca-Embasamento".

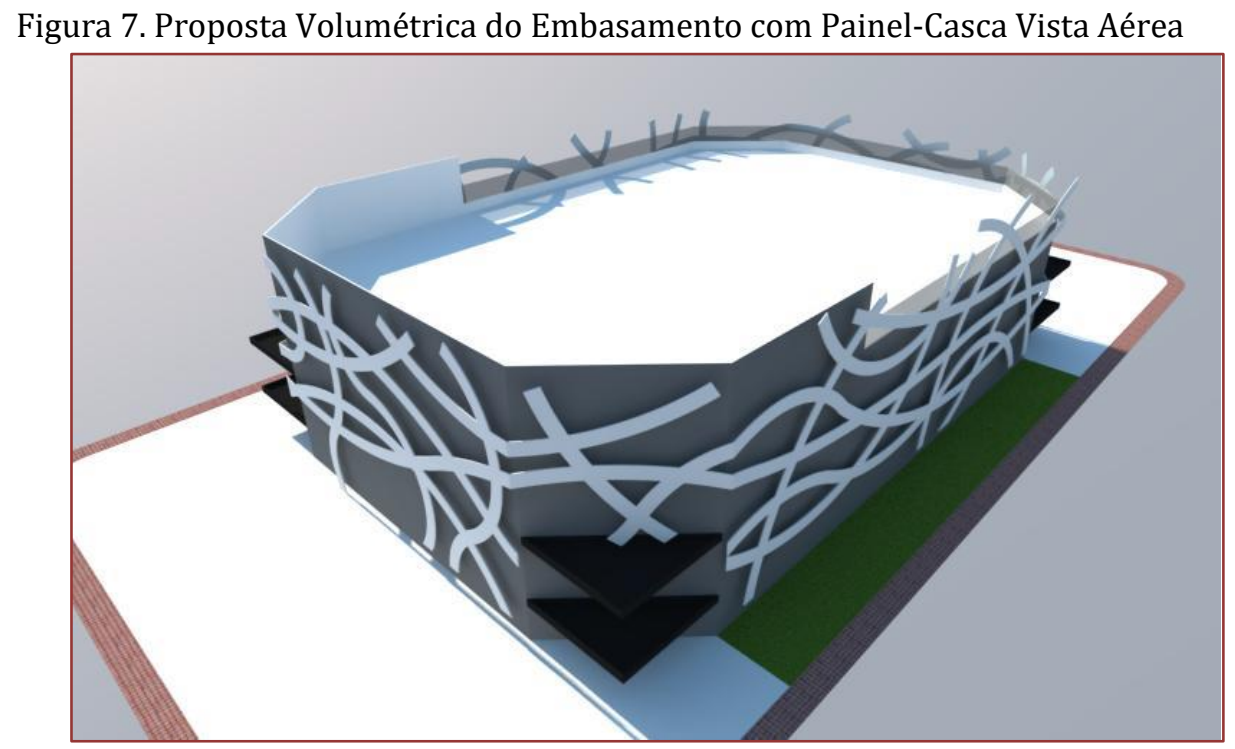

\subsubsection{PROPOSTA VOLUMÉTRICA DA TORRE E DO CONJUNTO EMBASAMENTO-TORRE}

Foram propostas algumas volumetrias para a torre buscando harmonizar seu partido arquitetônico com o embasamento. A torre está localizada exatamente no ponto médio da figura geométrica do embasamento, 
facilitando a concepção dos sistemas estruturais e valorizando o objeto arquitetônico. A forma da torre não poderia seguir um padrão comum, pois a necessidade de identidade estética transformava a concepção volumétrica da torre em um desafio para o projeto. Desta forma, optou-se por linhas retas e objetivas, porém para contrapor o ritmo, as linhas inclinadas foram adotadas, ao passo que sua implantação foi equilibrada para não comprometer o aproveitamento de espaço. Com a localização da torre no centro do embasamento, o equilíbrio foi estabelecido na planta baixa, garantindo um aspecto facilitador em termos de dimensionamento de espaço interno e aproveitamento da gleba. Na Figura 8 é possível visualizar a volumétrica final da torre e do embasamento harmonizadas.

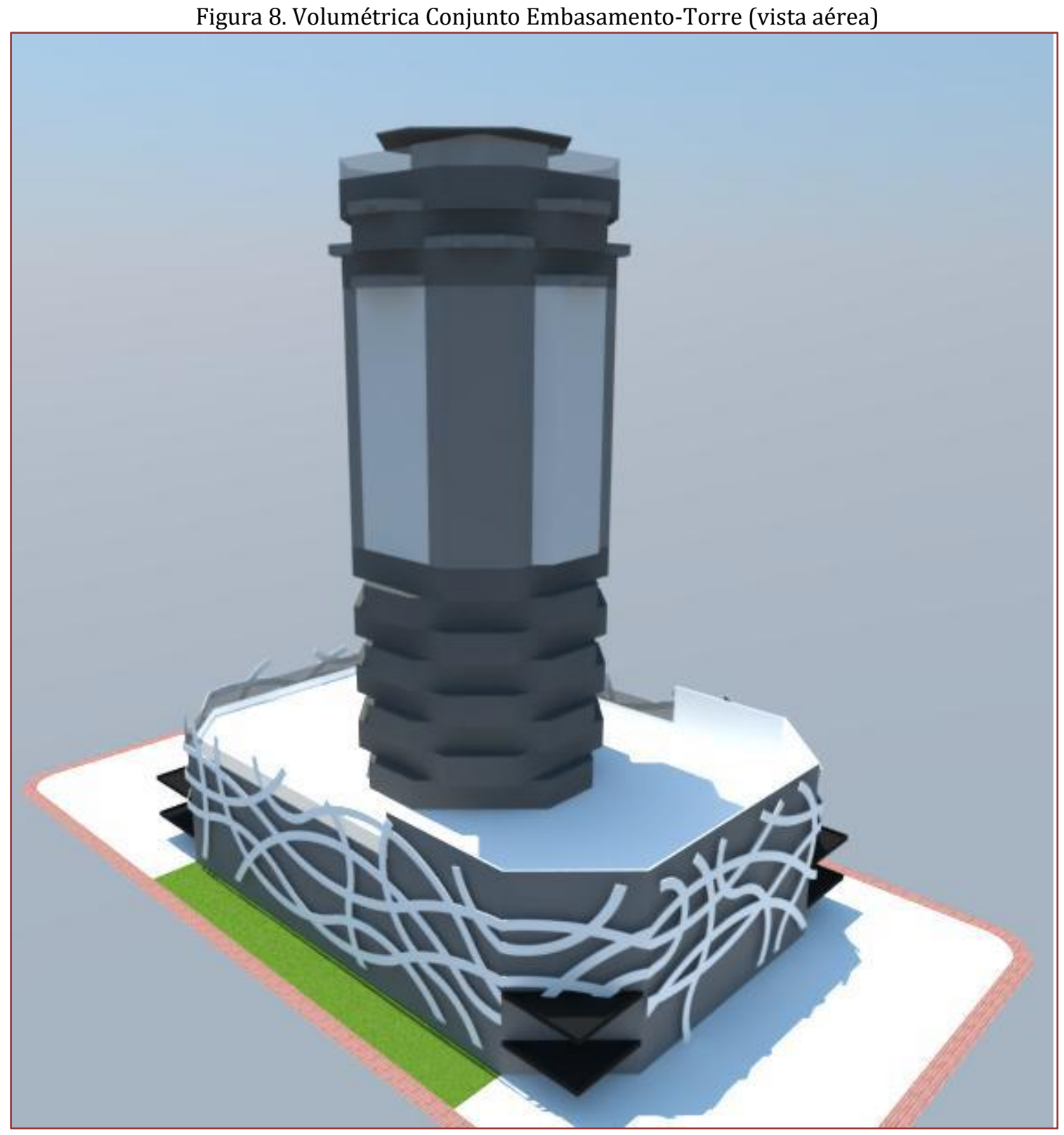

\subsection{ANTEPROJETO E PROJETO EXECUTIVO}

Esta etapa mostra o desenvolvimento do projeto, e acrescenta novos aspectos que influenciaram diretamente na concepção do objeto arquitetônico provocando modificações estéticas e funcionais, contemplando a transformação da ideia inicial. 


\subsubsection{MEMORIAL JUSTIFICATIVO}

Os acabamentos especificados no projeto tiveram o intuito de garantir conforto e praticidade para o empreendimento, além de proporcionar o melhor estético a edificação. No estacionamento, foi previsto um piso cimentado com pintura epóxi e tinta reflexiva nos pilares para que os motoristas tenham plena identificação dos elementos evitando acidentes. As faixas de indicação nos pisos terão pintura epóxi, para fácil identificação no uso dos faróis. Os brises terão função de ventilação cruzada reduzindo os gastos com ventilação artificial nos estacionamentos semi-enterrado e subsolo 01 . No subsolo 02 não foi possível garantir ligação com o meio externo para ventilação, desta forma o pé-direito foi elevado a 3,20m para acomodar as instalações dos dutos de ventilação.

A Caixa de elevadores foi locada na região central dos estacionamentos para deixar todos os pontos equidistantes e de fácil acesso, principalmente com relação às vagas para portadores de necessidades especiais e de idosos que foram locadas ao lado dos elevadores. Os vidros no embasamento serão temperados incolores de $10 \mathrm{~mm}$ de espessura garantindo segurança na possibilidade de sinistro, não havendo a desintegração do material em estilhaços. 0 porcelanato constitui um dos principais materiais para o acabamento nos pisos dos principais ambientes. Além de garantir beleza ao ambiente, sua fácil aplicação e durabilidade asseguraram sua recomendação para os compartimentos. Devido ao fluxo intenso de pessoas previsto, foi especificado PEI 4, de acordo com a NBR 13818/1997 (Placas cerâmicas para revestimento - especificação e métodos de ensaio), que indica o índice de resistência à abrasão devido ao tráfego de pessoas: PEI 4 - o produto pode ser utilizado em todas as dependências residenciais e pequenos ambientes comerciais que não tenham portas externas, como por exemplo: salas comerciais de shoppings ou galerias. Pode ter porta externa, porém com pouca sujeira abrasiva; Além disso foi previsto um acabamento polido, devido ao fluxo e a cor areia para dar leveza ao ambiente e oferecer superfície mais reflexiva de luz, auxiliando no desempenho das diversas atividades de escritórios.

0 forro definido foi o de gesso com acabamento em massa acrílica e pintura PVA na cor branco neve fosco, devido à fácil instalação, manutenção, capacidade de proporcionar iluminação direta ou geral através de pendentes ou luminárias embutidas, podendo também ser trabalhado para receber sancas iluminadas ou não. Nas paredes foram definidos emassamentos e pinturas com tinta acrílica na cor branca, para auxiliar na iluminação dos ambientes. A locação dos pilares e o emprego das lajes nervuradas serviram para dar maior amplitude ao espaço e facilitar a colocação das vagas de estacionamento, assim como evidenciar o aspecto de planta livre nos escritórios da torre, proporcionando maior liberdade de layout. Com isso alcançam-se maiores vãos, desde a cobertura da torre até o subsolo 02 do estacionamento, assegurando estabilidade estrutural e liberdade projetual. Os banheiros, lavabos e vestiários receberão peças sanitárias de fábrica, com marca a definir e suas paredes e pisos serão revestidos com porcelanatos naturais para garantir a segurança dos usuários quanto a sua mobilidade. 0 uso da escada no primeiro térreo para o segundo foi uma medida tomada para dar maior identidade estética ao ambiente interno do complexo.

Da entrada principal, é o primeiro objeto a ser contemplado, com caráter de escultura unindo a sua funcionalidade e a sua estética. No auditório, os assentos foram projetados no esquema Staduim para aproveitamento de espaço e locação do maior número de assentos possíveis, akém disso este tipo de auditório garante melhor visibilidade do palco dos expectadores, sem que os que estão sentdos a frente seja obstáculos visuais. As paredes do auditório de gesso acartonado em folha dupla com lã de vidro no miolo de $80 \mathrm{~kg} / \mathrm{m}^{2}$ garantem maior absorção possível do som, sua propriedade impede que o som se reverbere e prejudique a qualidade sonora do ambiente dando clareza ao que está sendo transmitido do palco. 0 teto com forro em gesso com acabamento em massa acrílica e pintura PVA é escalonado, conforme mostra o corte longitudinal no projeto executivo em anexo, para que o som seja direcionado para a platéia e. o piso em carpete nos restante dos amibeintes serve para amenizar os ruídos com passos e a escada possui sinalização no borcel para melhor orientação na ausência de luz.

A sala de audiovisual está localizada na parte superior direcionada para o palco para que os operadores tenham plena visão do que ocorre a frente. Na academia o piso será o emborrachado argamassado, devido ao uso específico para atividades físicas, prevendo absorção de impacto ao longo dos trabalhos e garantindo segurança aos usuários. As pistas de caminhada possuem piso em granito com acabamento apicoado para aumentar o atrito e evitar escorregões, os vidros em volta dão a opção de contemplação do entorno e os pergolados podem receber vegetação aérea, na forma de trepadeiras para compor o conjunto paisagístico do local. Na torre os pisos são os mesmos do embasamento, devido ao uso semelhante, as paredes, na grande maioria são em divisórias em drywall emassadas e pintadas com tinta acrílica na cor branca e podem ser removidas conforme a necessidades dos compradores que tiverem o intuito de juntar dois ou mais espaços, assegurando liberdade e versatilidade aos espaços. Os banheiros possuem opções alternativas de projeto, conforme mostra o projeto executivo em anexo, com banheiros adaptados a 
portadores de necessidades especiais. 0 restaurante está localizado no último pavimento e foi locado para dar oportunidade de contemplação da vista aérea da cidade, além de dar um caráter mais exclusivo aos usuários que preferirem ter reuniões de negócios.

\subsubsection{SOLUÇÕES DE CONFORTO AMBIENTAL}

Neste item, serão estudados os fatores que envolvem a adequação do projeto aos aspectos climáticos, ambientais e espaciais do ambiente em que está inserido, ressaltando sua aplicabilidade e os instrumentos usados para viabilizar condições adequadas de conforto.

\section{Elevador E Plataforma Elevatória Estacionária Para Portadores De Necessidades Especiais}

Devido a limitações espaciais, além da necessidade de viabilização de setorização dos camarins, foi necessária implantação de um instrumento que garantisse a acessibilidade dos deficientes físicos ao palco do auditório sem que isso comprometesse às necessidades do projeto. 0 elevador para deficientes físicos tem capacidade para levantar até $180 \mathrm{~kg}$ e é composto por uma coluna em perfis de chapas de aço A36 dobrado e enrijecido soldados entre si, paradas por sensores fins de curso com alimentação em 12 volts, sistema de elevação por fuso com rosca trapezoidal em aço 1045 laminado a frio. De acordo com a empresa Blotek, que comercializa o equipamento, o elevador possui duplo sistema de segurança (porcas principal e de segurança), porcas com embuchamento em tecnyl, braços de sustentação e elevação em aço inox, pintura em eletrostática na cor branca, carrinho movido com roldanas em aço, cadeira plástica acoplada ao braço, motor elétrico trifásico com potência de $1 \mathrm{cv}$.

Outra opção para transporte dos deficientes ao palco é a plataforma elevatória estacionária. Pode elevarse até dois metros, e de acordo com a empresa Evolution, suporta $250 \mathrm{~kg}$, movimentando-se através de fuso, acionado por motorredutor de $1 \mathrm{cv}$ a $220 \mathrm{~V}$ de tensão, sendo comandada pelo usuário por meio de botões nas laterais do painel de comando. Conta com sistemas de segurança que impedem a abertura das portas quando se encontram fora do nível correspondente e sua operação, quando uma das portas não estiver fechada, é travada. Sensores detectam qualquer interferência, impedindo o seu movimento e inclui botão de segurança que a paralisa automaticamente em qualquer posição em caso de emergência.

\section{Telha De Fibra Vegetal}

A fabricação envolve papel selecionado na reciclagem, que é posto em água quente para captação da fibra de celulose, que é prensada, ondulada e mergulhada em betume quente, que dará resistência mecânica à telha. Por fim, ocorre a aplicação de uma resina que tem por função proteger a telha dos raios UV, impedindo a escamação da superfície. 0 processo de fabricação adota conceitos de sustentabilidade, com baixo consumo de energia e reaproveitamento de água, apenas coma reposição do que é evaporado. Como a fibra de celulose é extraída do papel reciclado, o processo não envolve a exploração de árvores, além disso, o betume aplicado para impermeabilizar a telha não sofre queima, não provocando liberação de gás carbônico na atmosfera. De acordo com Flavia Souto, presidente da Onduline, muitos arquitetos estão se especializando em projetos ecologicamente sustentáveis, assim como as construtoras e as obras do governo que começam a adotar boas práticas de construção. Além de ser mais barato que os outros tipos de telha, oferecem redução nos custos da obra, pois reduz a quantidade de material empregado na sustentação do telhado devido a sua leveza. Por ser isolante térmico, apresenta bom desempenho em relação á transmissão de calor. A telha é bem resistente a ventos fortes, neve e chuva de granizo, comenta, dizendo que mesmo a telha não sendo isolante térmica, apresenta bom desempenho em relação à transmissão de calor. Apresenta inclinação maior que $18^{\circ}$ para os modelos de $2,00 \mathrm{~m} \times 0,95 \mathrm{~m}$ e $2,00 \mathrm{~m} \mathrm{x}$ $1,05 \mathrm{~m}$ e maior que $27^{\circ}$ para $0,50 \mathrm{~m} \times 0,95 \mathrm{~m}, 0,50 \mathrm{~m} \times 1,05 \mathrm{~m}$ e $0,40 \mathrm{~m} \times 1,06 \mathrm{~m}$. A vida útil da telha é indeterminada e depende de fatores ambientais externos.

\section{Vidro Insulado}

Os vidros duplos insulados apresentam ótimo desempenho quanto à emissividade, ao isolamento térmico, à transparência e à refletividade, proporcionando segurança e bom aspecto estético às fachadas. 0 vidro insulado foi trazido ao Brasil há quase 30 anos pela Providro, empresa do Grupo Pilkington e consiste, basicamente, em um produto composto por dois ou mais vidros separados entre si por um perfil de alumínio em todo seu perímetro, formando uma câmara - que contenha a mistura de ar com nitrogênio, 
gás argônio ou outros gases - hermeticamente fechada e livre de umidade e vapor d'água. 0 conjunto composto por vidros, gases e câmara é obtido pela dupla selagem. Porém, antes disso, é importante dar atenção ao corte, lapidação e lavagem dos vidros. Em seguida, prepara-se a câmara interna, preenchendo todos os perfis com sílica gel, que é capaz de desidratar o ar confinado e evitar o embaçamento, principalmente em período de alta umidade do ar, explica Odilon Reinaldo da Silva, sócio-diretor da Bend Glass, fabricante de insulado. "Para se fazer a primeira selagem, fixamos a fita dupla face nos dois lados dos perfis", esclarece. Nesta etapa aplica-se o butil, substância capaz de evitar a troca gasosa e, dessa forma, garantir a estanquidade, continua a explicação Leandro José Francisco, técnico-comer- cial da Contêmpera, outro fabricante. "Já a segunda selagem pode ser feita de polissulfeto ou de silicone, para assegurar a estabilidade do conjunto, além de reforçar a primeira selagem."

Com todos esses detalhes da dupla selagem é possível notar a importância que a medição de umidade do ar tem nessa fabricação. 0 gerente-técnico-comercial da Crismach, fabricante de máquinas para insulado, Ricardo S. Aragon, recomenda que a montagem do vidro seja feita em sala extremamente limpa. "Além disso, o ambiente deve ter um aparelho de ar-condicionado para manter a temperatura em, no máximo, 20 graus", sugere. Com isso, explica o gerente, o índice de umidade relativa do ar ficará com, no máximo, 50\%. Neste projeto foi aplicado uma nova tecnologia que utiliza persianas entre vidros insulados.

Desenvolvida para funcionar no interior da câmara selada, a persiana controla a iluminação, reduz a absorção de calor em até $85 \%$ e garante total assepsia ao ambiente. Pode ser acionada por meio de botão, haste, cordão contínuo ou motor. Para tanto é fundamental que a esquadria tenha dimensão com capacidade de receber vidros cuja espessura mínima seja de 28 ou $30 \mathrm{~mm}$, resultante da soma de dos vidros de $4 \mathrm{~mm}$ mais uma câmara de $20 \mathrm{~mm}$. Renato Acciardi, diretor da Acciardi, fabricante de persianas cujo sistema utiliza tecnologia nacional funciona com a transmissão via cabo especial, ressalta que o produto ainda contribui para a redução do consumo de energia com as máquinas de climatização de ambiente. Segundo ele, a incidência de raios solares é maior num vidro insulado sem persiana, o que acaba minimizada na aplicação do insulado com persiana entre vidros, pois ela é capaz de otimizar o desempenho do vidro, refletindo os raios solares para fora do ambiente.

\section{CONCLUSÃO}

A concepção deste projeto trouxe muitas contribuições para o aprimoramento dos conhecimentos acadêmicos. O trabalho final tem por meta reunir todos os conhecimentos adquiridos ao longo da faculdade e aplicá-los em uma criação que vise a sustentabilidade econômica, social e ambiental.

Com este projeto a aplicabilidade dos materiais foi aprimorada. A pesquisa sobre as técnicas construtivas e os materiais empregados foi fundamental para a aquisição de conhecimentos. Desta forma, os projetos adquiriram um caráter profissional - exigência importante para trabalho de conclusão.

Melhoraram também os aspectos projetuais, com respeito ao dimensionamento de espaços e a empregabilidade de cálculos referentes a número de peças de banheiros e tráfego de elevadores, reforçando ainda mais o que foi feito nos períodos anteriores nas diversas matérias específicas cursadas.

A pesquisa também foi um instrumento significativo no desenvolvimento do trabalho. Os métodos de pesquisa foram implantados, sobretudo nos históricos e estudos de caso.

Dessa forma, conclui-se uma importante etapa no desenvolvimento acadêmico, o curso de Arquitetura e Urbanismo propõe ao mercado, novos profissionais formados a partir de preceitos e técnicas, contribuindo para a evolução deste campo de conhecimento na região amazônica e buscando entregar profissionais que se preocupem com a coletividade, aplicando todo o conhecimento adquirido com uso racional dos recursos e do espaço.

\section{REFERÊNCIAS}

[1] ANDRADE, Cláudia. A História do Ambiente de Trabalho em Edifícios de Escritórios: Um Século de Tranformações. Ed. C4.São Paulo.

[2] Associação Brasileira de Normas Técnicas - ABNT. NBR 09050/2004 - Acessibilidade à Edificações, Mobiliário, Espaços e Equipamentos Urbanos.

[3] Associação Brasileira de Normas Técnicas - ABNT. NBR 09077/2001 - Saídas de Emergência em Edifícios.

[4] Associação Brasileira de Normas Técnicas - ABNT. NBR 13768/1997 - Porta Corta-Fogo de Emergência. 
[5] Associação Brasileira de Normas Técnicas - ABNT. NBR 13994/2000 - Elevadores de Passageiros Elevadores para Transportes de Pessoa Portadora de Deficiência.

[6] Associação Brasileira de Normas Técnicas - ABNT. NBR 5665/1983 - Cálculo de Tráfego nos Elevadores.

[7] CHING, Francis D.K.. Arquitetura - Forma, Espaço e Ordem. Ed. Martins Fontes. 2ª edição. São Paulo, 2008.

[8] Corpo de Bombeiros. Instrução Técnica № 11/2001 - Saídas de Emergência em Edificações.

[9] Corpo de Bombeiros. Instrução Técnica № 13/2001 - Pressurização de Escada de Segurança.

[10] DE SOUZA, Felipe Silveira. A adoção de parques urbanos na cidade de Porto Alegre: Publicidade e reprodução do capital da iniciativa privada através de espaços públicos. Instituto Federal de Santa Catarina/Universidade Federal de Santa Catarina. 2010.

[11] GURGEL, Miriam. Projetando Espaços - Guia de Arquitetura de Interiores para Espaços Comerciais. Ed. SENAC, São Paulo.

[12] http://www.aecweb.com.br - 24.11.11 às 13h 34min

[13] http://www.athiewohnrath.com.br - 12.05.11 às $14 \mathrm{~h} 22 \mathrm{~min}$

[14] http://www.emporis.com - 12.05.11 às $13 \mathrm{~h} 29 \mathrm{~min}$

[15] http://www.engenhariacivilnanet.blogspot.com - 29.11 .11 às 01h 23min http://www.largemind.pt 02.12.11 às $14 \mathrm{~h} 56 \mathrm{~min}$

[16] http://www.nei.com.br - 24.11.11 às $11 \mathrm{~h} 50 \mathrm{~min}$

[17] http://www.perfilarc.com.br - 02.12.11 às 14h 50min 131

[18] http://www.porcelanatos.com - 02.12.11 às 12h 43min

[19] http://www.portalamazonia.com.br - 30.04.2011 às 16h 27min

[20] http://www.quebarato.com.br - 24.11.11 às $11 \mathrm{~h} 50 \mathrm{~min}$

[21] http://www.revistaau.com.br - 16.11.11 às 02h 56min

[22] http://www.toyo-ito.co.jp - 12.05.11 às 13h 26min

[23] Lei 672/2002 - A Lei de Uso e Ocupação do Solo na Cidade de Manaus.

[24] Lei 673/2002 - Código de Obras do Município de Manaus.

[25] MASCARÓ, Juan L.. e YOSHINAGA, Mário. Infra-Estrutura Urbana. Ed. +4. 1aㅡ edição. Porto Alegre, 2005.

[26] MASCARÓ, Juan L.. Infra-Estrutura da Paisagem. Ed. +4. Porto Alegre, 2008.

[27] MONTENEGRO, Gildo A.. Desenho Arquitetônico. Ed. Edgard Blucher LTDA. 4ํㅡㄹ. ed.. São PAulo, 2001.

[28] Revista O Vidro Plano. Insulado: Um Polivalente Congênito. Edição 414. Junho, 2007. 


\section{Capítulo 2}

\section{Bim 8d: Estudo de caso da avaliação de risco no almoxarifado do canteiro de obras}

\section{Gleice Ana da Fonseca \\ Luciane Farias Ribas \\ Sara Santarém}

Resumo: A construção civil é um dos setores com os maiores índices de acidentes dentre as atividades desempenhadas pelo homem. 0 gerenciamento de obras deve incluir em seus processos a gestão de risco. Porém não é tarefa fácil gerenciar riscos na construção civil tanto pela complexidade dos projetos quanto pelo número de pessoas envolvidas. A gestão da informação na construção chamada de BIM (Building Information Management) pode tornar a prevenção e avaliação de acidentes em canteiro de obras mais eficazes. 0 objetivo deste trabalho é verificar a contribuição do Bim 8D para prevenção de acidente no canteiro de obra. Por meio de estudo de caso que avaliou os riscos em um almoxarifado de um canteiro de obras foi possível identificar as ferramentas do BIM 8D que poderiam ser implementadas. Foi possível identificar também os requisitos necessários para a implementação do modelo do gerenciamento de risco do BIM 8D.

Palavras chave: BIM. 8D. gerenciamento de risco. segurança. 


\section{INTRODUÇÃO}

O gerenciamento da construção civil está passando por mudanças muito importantes, principalmente no que diz respeito aos seus processos. Essas mudanças buscam tornar-se as tomadas de decisões mais eficazes. Para isso o uso da tecnologia vem contribuindo em todas as etapas do processo do gerenciamento.

Com a necessidade de tomadas de decisões rápidas e com resposta ainda mais rápidas, o uso de tecnologias como a do BIM (Building Information Management) vem sendo muito utilizada. Essa tecnologia permite gerenciar de forma virtual todas as etapas de uma construção, inclusive na gestão dos riscos. Para contribuir para o conhecimento da aplicação de BIIM na dimensão 8D o presente trabalho propõe Verificar a contribuição do Bim 8D para prevenção de acidente no canteiro de obra. A metodologia empregada foi para identificar o risco que os colaboradores estão expostos no setor do almoxarifado. Elaborar programa de implementação do Bim no setor do almoxarifado e o risco que pode prever. Propor melhoria para prevenção de acidente com a implantação do BIM.

O BIM é dividido em dimensões que vão do modelo 3D, o qual deve ser o primeiro passo para modelagem da informação da construção, até a dimensão pós ocupação. A dimensão que gerencia o risco de um empreendimento é chamada de 8D. Nessa dimensão são utilizadas ferramenta para prevenção e avaliação dos acidentes na construção civil. Assim como nas outras dimensões, para implementar o BIM 8D é necessário um tempo maior de planejamento. A precisão das informações influencia muito na eficiência da adoção das ferramentas para a prevenção e avaliação de acidentes. Outra ação que fortalece o uso das ferramentas do BIM 8D para o gerenciamento de riscos é a geração de banco de dados sobre riscos da construção. Essas informações dependem muito da equipe de gestão de riscos que precisa passar sua experiência para o modelo de gestão na dimensão BIM 8D. As ferramentas que podem ser usadas vão desde de modelos virtuais a sistemas de monitoramento remoto. Porém a implementação de ferramentas do BIM 8D necessitam de muito treinamento. Além do treinamento é necessário escolher um modelo piloto do projeto para aplicação da tecnologia BIM 8D.

Apesar dos avanços tecnológicos no gerenciamento de risco com o BIM 8D, ainda é pouco utilizada essa tecnologia em canteiros de obras. Por essa razão torna-se fundamental a disseminação do uso das ferramentas do BIM na dimensão 8D para a prevenção de acidente na implantação do canteiro de obras. Os estudos e pesquisas em BIM 8D ainda são considerados iniciais, porém demonstram muitas vantagens quanto a prevenção de acidentes no canteiro de obras.

\section{FUNDAMENTAÇÃO TEÓRICA}

\subsection{SEGURANÇA E PREVENÇÃO DE ACIDENTES NA CONSTRUÇÃO CIVIL}

A segurança é um processo fundamental no processo da construção civil. A sua finalidade é proteger e evitar a ocorrência de acidentes através da prevenção. A prevenção de acidentes além de promover uma melhoria na qualidade de vida para seus operários aumenta a produtividade. A segurança na construção tem a capacidade de desenvolver processos que possa reduzir riscos para os trabalhadores que estão em atividade no campo. Os perigos no canteiro de obra são diversos o que pode comprometer a integridade e a saúde dos operários. A empresa deve fornecer ou disponibilizar aos seus profissionais materiais e equipamentos de prevenção individuais e coletivo para que possa ser utilizado para garantir a total segurança na construção de uma obra (SILVA, 2015).

Segundo Lima (2017), a construção civil é uma profissão que mais oferece riscos aos trabalhadores, observa-se que há muitos acidentes e até óbitos que de fato acontece nas obras. 0 risco é um dano ou perda esperado no tempo de uma atividade executado. Existem diversos riscos em uma construção. Entretanto, o risco pode existir por irresponsabilidade da empresa ou até mesmo do próprio funcionário. Mas as empresas são muito cobradas nos locais de trabalho e devem garantir que as atividades ocorram sobre total segurança. É importante lembrar que não existem riscos de acidentes mais esperados e sim riscos que pode surgir no seu ciclo de vida. No Brasil, a maioria dos acidentes acontece por falta de planejamento e organização durante a construção.

Sabe-se que existem alguns riscos de acidente mais comuns no canteiro de obra. Os riscos mais comuns são: desorganização, falta de atenção, choques elétricos, queda de materiais, queda em altura, falta de sinalização, manuseio de ferramentas, falta de atenção com máquinas, soterramento, desmoramento e ruído alto. Esses acidentes podem acontecer durante a execução de trabalho, na maioria das vezes ocorre por negligência da empresa ou desatenção do próprio operário (LIMA, 2017). A NR18 é a norma que 
dispõe sobre as condições e meio ambiente de trabalho na indústria da construção civil as medidas de controle e sistemas preventivas de segurança nos processos do canteiro de obras. Há ainda programas que são implementados na empresa com objetivo de promover a proteção aos seus funcionários em seu local de trabalho. Os programas são: (PPRA) - programa de prevenção de riscos ambientais; (PCMAT) programa de condições e meio ambiente de trabalho; (PGR) - programa de gerenciamento de riscos; (PCMSO) - programa de controle médico de saúde ocupacional e (CIPA) - comissão interna de prevenção de acidentes. Os programas são implementados de acordo com as medidas estabelecida na norma. A empresa que organiza o ambiente do canteiro de obras seguro oferece serviços com boa qualidade. Outro benefício da implementação dos programas é a redução de gastos devido a ocorrência de acidentes. Portanto, a empresa que investe na implementação das normas segurança, aumenta os retornos financeiros da empresa (GUO et al., 2019).

A maior dificuldade que a empresa tem ao implementar os programas de prevenção, é aplicar as normas que estabelece os parâmetros ou que requer um maior conhecimento de seus profissionais, geralmente, a falta de conhecimento dos profissionais responsável pela empresa, a falta de informação dos programas que apresenta conforme a norma estabelece, elaboração dos documentos que são exigidos para implementação dos programas e falta de planejamento da empresa (YANG et al., 2017). As normas e legislação de segurança tem a função de criar algumas normas exclusivas relacionadas à segurança no trabalho e tem como objetivo fornecer parâmetros para prevenir a segurança e evitar os riscos causados por um acidente de trabalho.

O canteiro de obra pode ser dividido em: Setor da área operacional e Setor da área de vivência. O Setor da área operacional é composto por: Portaria, escritório, almoxarifado, depósito dos diferentes materiais, central de pré-moldados, central de montagem de instalações e esquadrias, central de concreto, central de argamassa, central de armação, central de fôrmas. O Setor da área de vivência é composto por: Vestiário, instalações sanitárias, alojamento, refeitório, cozinha, lavanderia, ambulatório e área de lazer. 0 papel principal do setor almoxarifado é armazenar todos os materiais que são fornecidos para a obra. Controlar o estoque de produtos da obra também é uma das suas funções, além de receber e distribuir os materiais para os operários. 0 almoxarifado tem que estar sempre abastecido para que a obra não pare por falta de material. Portanto, o almoxarifado tem a finalidade de guardar os materiais de consumo interno da obra para que não haja perda dos mesmos (SAMPAIO et al., 2020).

Dada a importância da segurança dos operários e da organização do canteiro, o planejamento das operações durante a construção é essencial para que se garanta o gerenciamento dos riscos. Com o gerenciamento de risco é possível identificar, quantificar e gerenciar os riscos de uma obra. É uma das dez áreas de conhecimento de um gerente de projetos. Porém, uma das dificuldades de se gerenciar os riscos de um projeto de construção é a complexidade das interações das atividades, o número de atividades e de pessoas envolvidas. Diante da importância do gerenciamento dos riscos e da necessidade de melhorar a comunicação na indústria da construção, surgi a tecnologia como aliada neste processo.

\subsection{MODELAGEM DA INFORMAÇÃO DA CONSTRUÇÃO (BIM)}

SOUZA (2019) diz que o BIM é estruturado conforme seu ciclo de vida em uma obra, porém existe a possibilidade de exigência no planejamento de um projeto. Todo empreendimento exige uma estruturação que deve ser contemplado na forma de um cronograma. Assim a estrutura deve ser montada de acordo com orçamento planejado da obra.

Finalmente, o projeto nos últimos anos teve um grande avanço com os avanços tecnológicos. Os projetos ficaram mais digitais e com informações que podem ser compartilhadas entre as partes. Isso se deve ao sistema de gerenciamento da informação da construção do Inglês Building Information Management - BIM.

Neste sistema de gerenciamento, é exigido um nível de detalhamento maior e com o maior número de informações possíveis sobre o projeto. É fundamental que a plataforma apresente transparência no processo de planejamento, para que seja possível adaptar o processo estruturado no modelo BIM. É possível detectar alterações no processo operacional em todo seu processo construtivo conforme a dimensão e suas classificações (SOUZA, 2019). Segundo GARIBALDI (2020) a dimensão é detalhada de acordo com as seguintes classificações: 3D, 4D, 5D, 6D, 7D e 8D. 0 BIM é uma ferramenta que tem a capacidade de identificar qualquer processo visto no gerenciamento de risco, nos modelos 3D e 4D tem a capacidade de visualizar o projeto e modificar todo os parâmetros do interesse do profissional, o Bim tem a possibilidade de reduzir possível erros na fase de uma construção (HEATON et al., 2019). 
Segundo CARVALHO (2017) esses softwares tem facilidade de realizar um número elevado de atividades no projeto. Isso aprimora o gerenciamento do projeto em todo seu ciclo e gerando diversas informações como utilizar cada uma das ferramentas. Como exemplo, os softwares podem identificar e avaliar erros no projeto. Quanto às desvantagens são apontadas a compatibilidade dos programas e se é utilizado na dimensão.

\subsection{DIMENSÃO 8D DO BIM PARA O GERENCIAMENTO DE RISCOS}

Segundo GARIBALDI (2020) a dimensão passou a surgir a partir das necessidades gerada no trabalho de um modelo virtual. É necessário para isso gerar um banco de dados de informações de prevenção de acidentes na construção civil. Na dimensão 3D passaram a desenvolver projetos com representação gráfica nos desenhos, mas foi elaborado outras dimensões que se uniram em um só grupo.

O risco de acidentes é um desafio muito grande para pequena e grandes empresas que se torna indesejável na maioria das vezes, de acordo com que se avalia a análise do gerenciamento de riscos. É um sistema que visa identificar toda a qualidade de riscos exposto numa situação de uma elaboração de projeto (VASCONCELOS, 2019).

De acordo com o processo de gerenciamento de risco, existe uma estrutura usada nos setores a longo prazo que permite os profissionais ou colaboradores trabalhem em conjunto para identificar riscos. 0 gerenciamento a princípio visa planejar a estrutura do projeto para que possa identificar o risco em toda sua etapa de execução. Na maioria das vezes é utilizado projeto anteriores para fazer a correção de um novo projeto (VASCONCELOS, 2019).

O BIM é uma ferramenta fundamental na informação e comunicação entre o gerenciamento de risco, na maioria das industrias é utilizada a dimensão para identificar risco de segurança em uma obra. É aplicada para detectar conflitos especiais em uma máquina (como um guindaste) ou projeto (AHMAD et al., 2018). A exigência para fazer a implementação da dimensão é exigida devido ao elevado índice de acidentes.

0 gerenciamento de risco no BIM se baseia em modelos de tecnologia de informação reativos e proativos. Em Sistemas Reativos são utilizadas informações por meio de tecnologias como realidade virtual, 4D CAD e GIS. Nessas tecnologias a informação precisam ser coletadas para serem analisadas ou avaliadas (KIM et al., 2020). O Sistema Proativo é utilizado para processar e coletar dados em tempo real de uma obra. É comum o uso de sensores que recebem sinais avisando nos equipamentos de proteção individual (KIM et al., 2020).

0 gerenciamento de riscos por meio de BIM, teve um grande avanço na área da tecnologia. Desenvolvendo software para facilitar as atividades no BIM no processo de planejamento do projeto da construção civil. 0 sistema é baseado em conhecimento que deve contribuir a visualização do gerenciamento dos riscos em um determinado projeto. Trazendo informações futuras em todo seu ciclo de vida do canteiro de obra, esse é um modelo que os profissionais encontraram para identificar riscos e segurança em banco de dados. Porém o BIM extrai e armazena informação que identifica riscos de segurança no planejamento do projeto (TAKIM et al., 2016).

Verificação automáticas de regras, é um programa instalado em um computador que avalia toda a execução de um projeto. A regra é uma aplicação que garante que todo trabalho de projeto seja padronizado em códigos de construção (TAKIM et al., 2016). A tecnologia de banco de dados tem a capacidade de fornecer as informações de maneira mais inteligente, tornando esse sistema de monitoramento de segurança mais aprimorado. A realidade virtual e bancos de dados que autoriza as informações em ambiente de projeto virtual, realiza uma melhor visão na simulação de uma pessoa andando no projeto e identificaria riscos de segurança futuras (BOURHIM E CHERKAOUI et al., 2020). De acordo com que o programa CAD 4D estabelece, ele faz todo o planejamento computacional do projeto detectando o tipo de risco de trabalho em altura. O BIM trabalha em conjunto com umas das ferramentas CAD 3D e 4D para facilitar a organização do gerenciamento de risco na construção civil (RAHIMIAN et al., 2020).

O sistema de informação geográfica, defini o nível máximo de detalhe no trabalha com atividade de programa de informação no ambiente do canteiro de obra. O sistema amplia a modelagem BIM para melhorar a visualização dos riscos de segurança e custos dos projetos executados. A partir desta visão, é comum observar que os sensores que recebem sinais de aviso passivos em equipamentos para a identificação de monitorar e controlar os riscos de segurança no canteiro de obra (RAHIMIAN et al., 2020). 
O BIM é uma versão de tecnologia que ajuda analisar a identificação dos possíveis gerenciamentos de riscos e acidentes do canteiro de obra, em todo seu ciclo de vida ou tempo real de um projeto. Existe diversos desafios em um projeto, é necessário fazer a implantação do BIM para dá suporte ao sistema de visualização, a identificação garante um melhor conhecimento para os profissionais de como se deve se proceder em determinadas situações de risco e segurança no ambiente de trabalho (TAKIM et al., 2016).

\section{METODOLOGIA}

\subsection{ESCOLHA DO LOCAL PARA A AVALIAÇÃO DO RISCO DE ACIDENTES}

Para o estudo da implementação do BIM 8D foi necessário escolher uma obra a qual apresentasse disponibilidade para fornecer as informações necessárias. A obra escolhida trata-se de um empreendimento residencial situado na Zona Norte da cidade de Manaus. A área total do empreendimento é 18.620,22 $\mathrm{m}^{2}$. Na Figura 1 é apresentado o projeto de implantação do empreendimento.

Figura 1 - Projeto de implantação do empreendimento escolhido para o estudo.

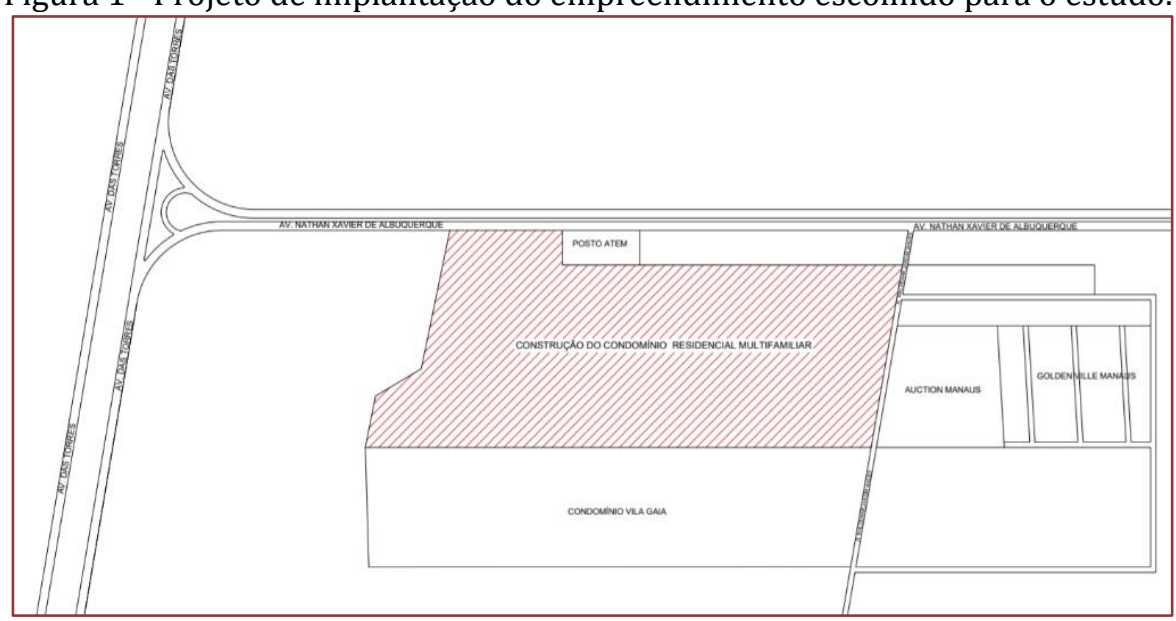

Fonte: Autoria Própria, 2020.

O empreendimento além da disponibilidade, apresentava um cenário adequado para o estudo devido a sua extensão e volume de serviços. No período de realização desse estudo a obra apresentava os lotes e arruamento definidos, construção do salão de festa e portaria. As instalações provisórias para esta etapa estavam situadas conforme a Figura 2.

Figura 2 - Layout do canteiro com a indicação das obras em andamento no período do estudo.

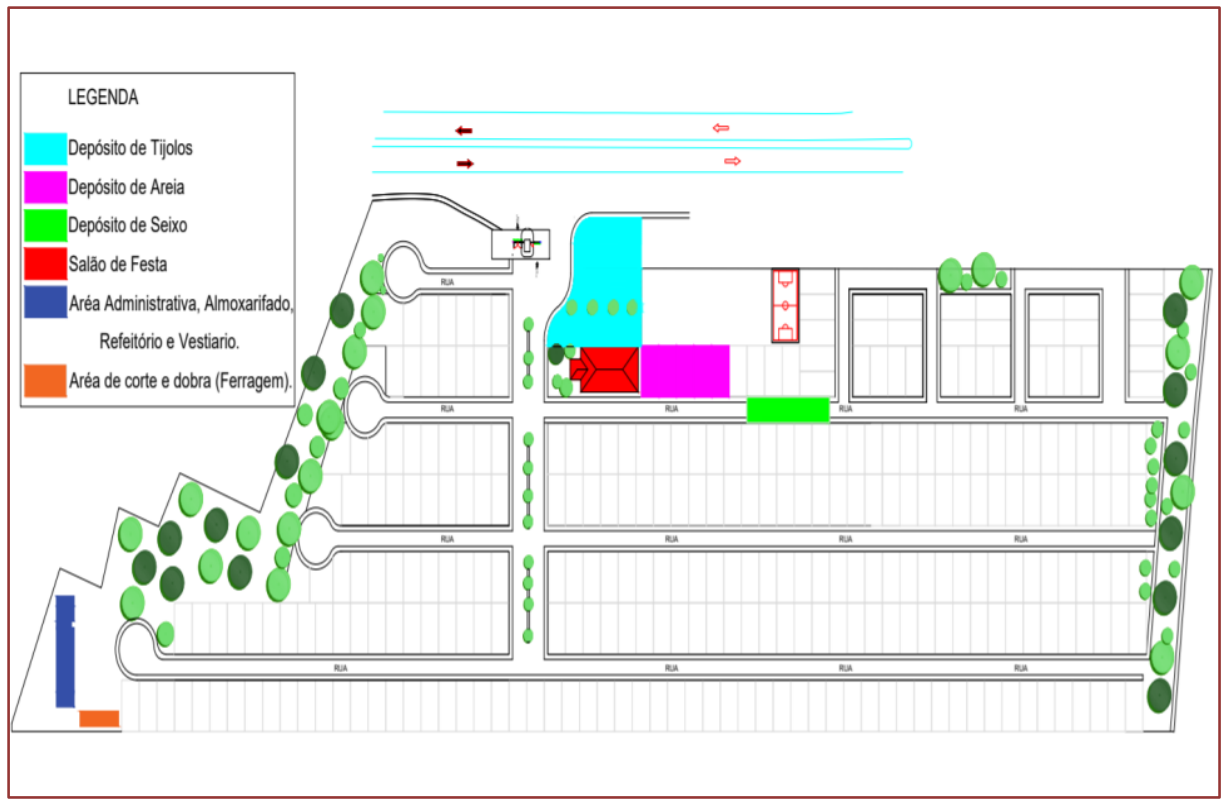


As instalações do canteiro são constituídas de: Administração, Almoxarifado, Área de convivência, Área de armazenagem de materiais, Carpintaria e serralheria e Área de descarte. A disposição das instalações no canteiro apresentava riscos aos trabalhadores, porém o almoxarifado apresentava uma diversidade maior de riscos de todos, como pode ser visualizado nas Figuras 3 e 4 que apresentam o interior do almoxarifado.

Figura 3 - Vista dos fundos no interior do almoxarifado

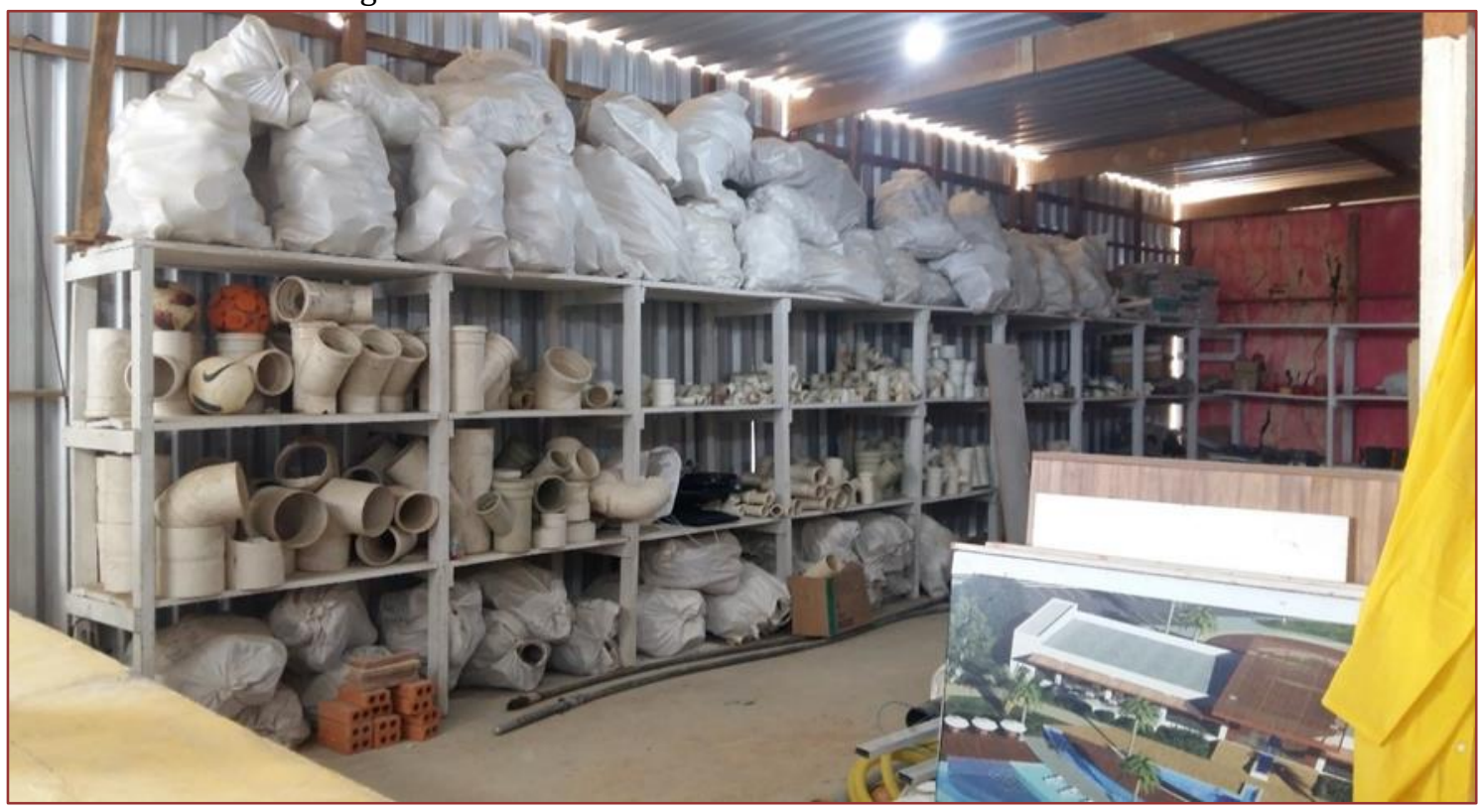

Fonte: Autoria Própria, 2020

Figura 4 - Vista lateral direita do interior do almoxarifado

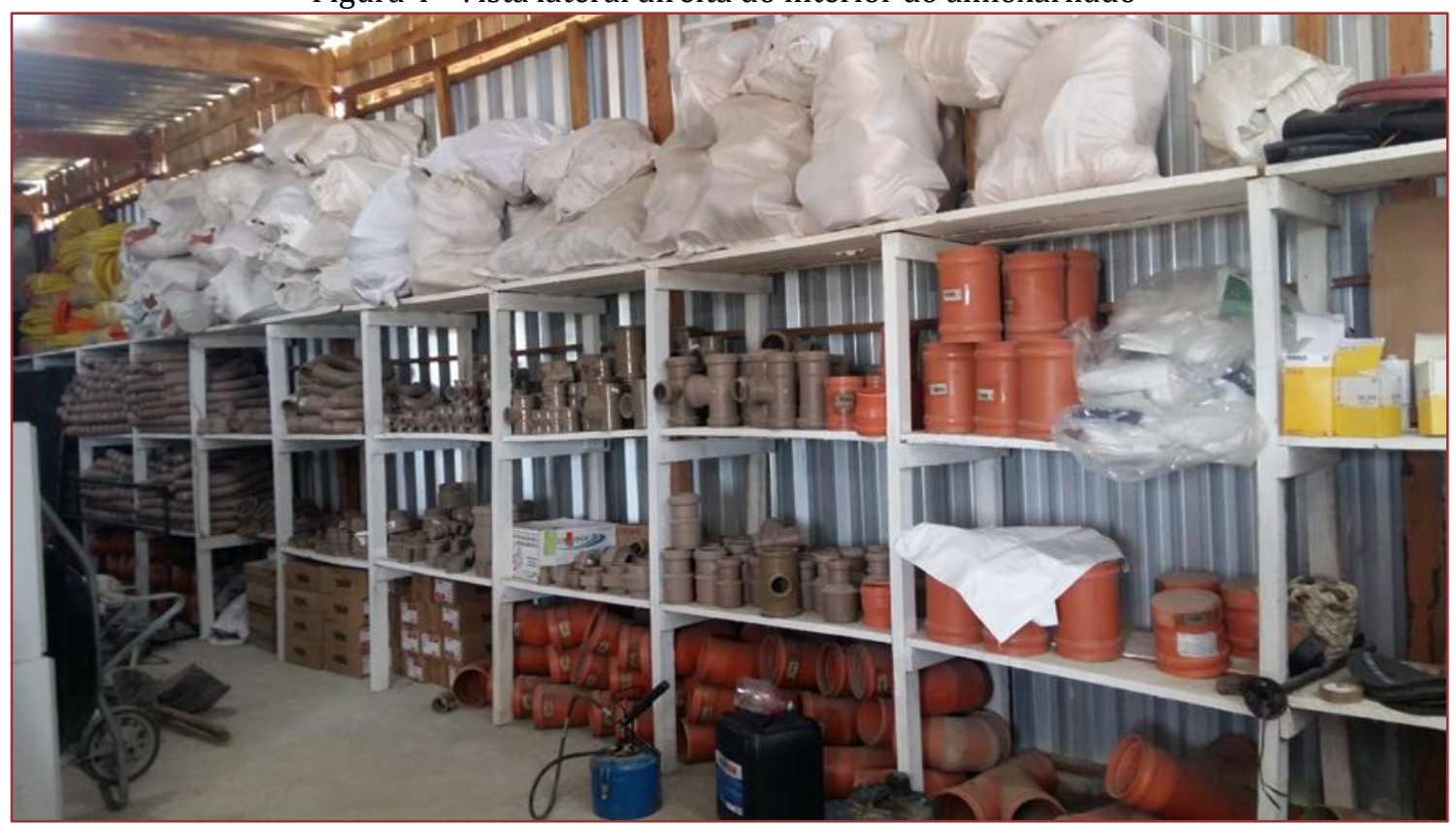

Fonte: Autoria Própria, 2020

Os riscos identificados ofereciam para implementação do BIM 8D informações mais completas. Portanto, o almoxarifado foi escolhido como modelo piloto para o estudo da implementação do BIM 8D nesta obra. Para a identificação dos riscos foi realizado o mapa de risco do almoxarifado. 


\subsection{MAPEAMENTO DO FLUXO DO LOCAL ESCOLHIDO}

Além dos riscos identificados no mapa de riscos, foi necessário avaliar o fluxo das operações dentro do almoxarifado. Para isso foi adotada a metodologia de fluxograma, a qual permite identificar as atividades de: transporte, espera, movimentação, armazenamento e estoque de acordo com a simbologia apresentada Quadro 1.

Quadro 1 - Simbologia do fluxograma

\begin{tabular}{|c|c|c|}
\hline Representação & $\begin{array}{c}\text { Representação } \\
\text { gráfica }\end{array}$ & Descrição \\
\hline $\begin{array}{l}\text { Operação de } \\
\text { transformação }\end{array}$ & & $\begin{array}{l}\text { O círculo representa a transformação ou montagem de um material. Por } \\
\text { exemplo: a concretagem, a armação, o assentamento de tijolos, a execução } \\
\text { das instalações elétricas, a montagem de fôrmas. }\end{array}$ \\
\hline Armazenagem & & $\begin{array}{l}\text { O triângulo representa todas as atividades armazenagem ou estocagem } \\
\text { dos materiais, tais como: areia, cimento, cerâmico etc. }\end{array}$ \\
\hline $\begin{array}{l}\text { Movimentação } \\
\text { e transporte }\end{array}$ & & $\begin{array}{l}\text { A seta representa o movimento de materiais, seja manual, com carrinhos } \\
\text { ou veículo motorizado de transporte. }\end{array}$ \\
\hline Inspeção & & $\begin{array}{l}\text { O quadrado simboliza as inspeções que ocorrem durante a produção. Por } \\
\text { exemplo: controle de qualidade do produto, controle de nível e prumo, } \\
\text { contagem ou pesagem de materiais no recebimento, marcações de } \\
\text { alvearia, registro de cotas, conferência com o projeto, medição etc. }\end{array}$ \\
\hline Espera & & $\begin{array}{l}\text { A letra "D" representa paradas e esperas na produção, ou seja, quando as } \\
\text { pessoas ou os equipamentos ficam aguardando o prosseguimento do } \\
\text { trabalho. }\end{array}$ \\
\hline
\end{tabular}

Fonte: Autoria Própria, 2020

Uma vez identificadas essas atividades, foi possível obter o mapeamento do fluxo das operações no interior do almoxarifado. A partir do mapeamento do fluxo foi possível avaliar as atividades que comprometiam ergonomicamente o trabalho no almoxarifado.

\subsection{LEVANTAMENTO DAS ATIVIDADES DE RISCO}

Para identificar as atividades ergonomicamente prejudiciais foram utilizados os fluxogramas das operações no interior do almoxarifado. Entre os domínios de competência estabelecidos pela Associação Internacional de Ergonomia o estudo se concentra apenas nos riscos ergonômico físicos. Os riscos ergonômicos físicos foram avaliados de acordo com a NR17 (ABNT, 2020). As atividades identificadas foram classificadas quanto à frequência de ocorrência e o grau de risco.

\subsection{IDENTIFICAÇÃO DAS FERRAMENTAS DE GERENCIAMENTO DE RISCO BASEADAS EM BIM 8D}

Nesta etapa, baseado no artigo "A review of risk management through BIM and BIM-related technologies" (Yang Zou et. al., 2017), o qual está entre os 25 artigos mais relevante nos últimos 5 anos sobre Gerenciamento de risco baseado em BIM (BIM-based risk management) na base de dados cientifica "Science direct". As ferramentas indicadas por esse artigo foram selecionadas para o estudo dos potenciais risco relacionados no almoxarifado.

\subsection{O USO DAS FERRAMENTAS DE GERENCIAMENTO DE RISCO DO BIM 8D NO ESTUDO DE CASO}

As atividades de riscos identificadas na Fase 1 foram relacionadas com as ferramentas do BIM selecionadas na fase 2 . As informações foram alocadas de acordo com a necessidade de cada ferramenta para a avaliação do risco de acidentes. Também foram identificadas informações adicionais que não foram consideradas na concepção do projeto. 


\subsection{ELABORAR UM ROTEIRO DE IMPLEMENTAÇ̃̃O DE UM MODELO BASEADO NO BIM 8D}

Nesta fase foram avaliadas as informações insuficientes ou inexistentes baseado no estudo de caso, que podiam comprometer o uso das ferramentas do BIM 8D. Essa analise permite elaborar uma lista de prérequisitos para a implantação de canteiro de obras utilizando BIM. Também foram relacionados os instantes em que esses pré-requisitos devem ser providenciados. Baseado no estudo dos riscos de acidentes ergonômicos do almoxarifado do estudo de caso, um roteiro de implementação de BIM 8D do modelo piloto foi montado. Esse roteiro ajudará na implantação de canteiros de obras utilizando o BIM 8D.

\section{RESULTADOS}

Neste capitulo serão apresentados e discutidos os resultados obtidos nas etapas de levantamento de riscos, identificação das ferramentas de BIM 8D e elaboração do roteiro de implementação do modelo piloto de BIM 8D.

\subsection{LEVANTAMENTO DE RISCO NO ALMOXARIFADO.}

Utilizando a ferramenta Mapa de Risco foi possível identificar os potenciais riscos oferecidos pela organização e arranjo do almoxarifado. A Figura 5 apresenta o mapa de risco do almoxarifado. Os riscos físicos identificados correspondem ao calor e umidade. Devido os materiais utilizados na construção do almoxarifado, no ambiente armazenava muito calor. Foi identificado também pontos com umidade devido à falta de impermeabilização na interface com o solo.

Figura 5 - Mapa de Risco do Almoxarifado

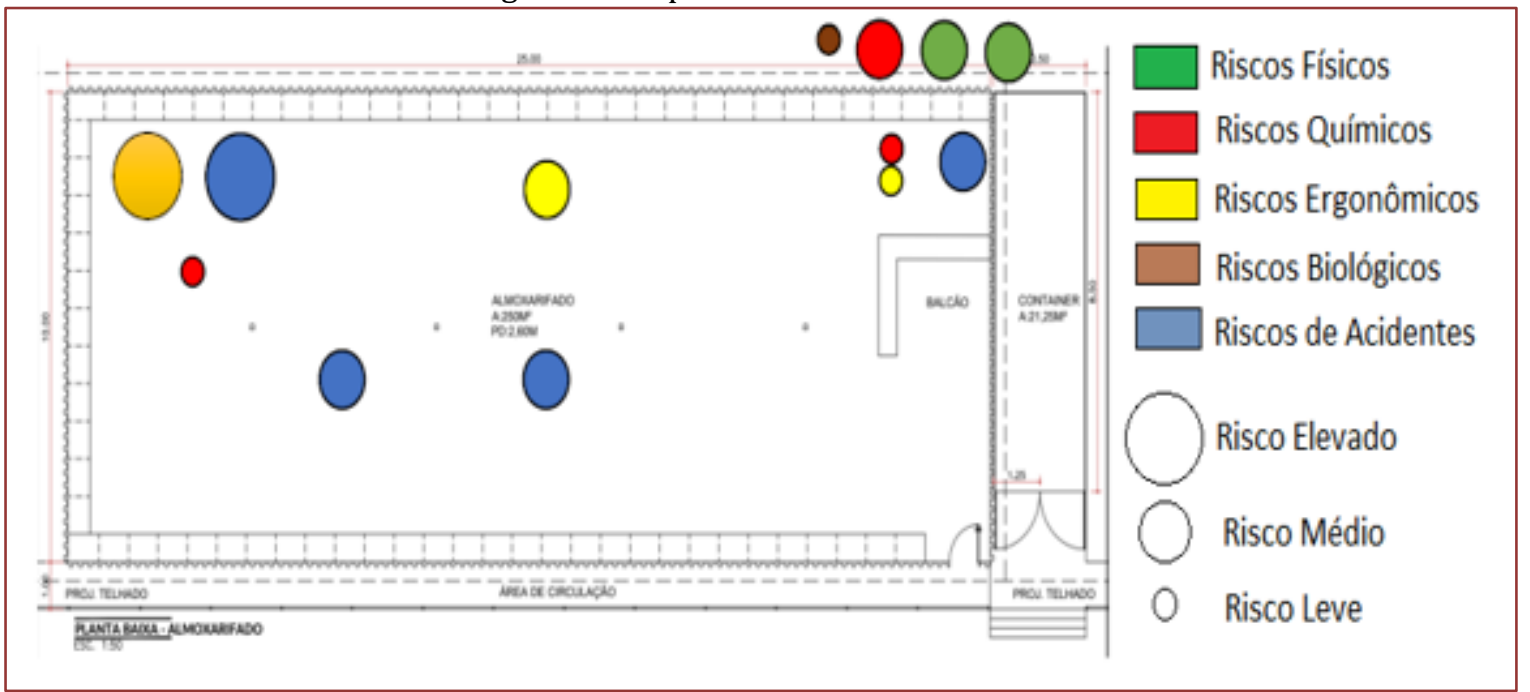

Fonte: Autoria Própria, 2020

Os riscos físicos identificados correspondem ao calor e umidade. Devido os materiais utilizados na construção do almoxarifado, no ambiente armazenava muito calor. Foi identificado também pontos com umidade devido à falta de impermeabilização na interface com o solo.

0 armazenamento de materiais de limpeza, tintas e combustível no interior do almoxarifado foram identificados como riscos químicos leve. Ausência de revestimento de piso, o qual era feito de cimento, gerava uma concentração de poeira elevada, podendo causar problemas respiratórios, classificando como risco químico médio. Como risco biológico foram identificadas as possíveis formações de fungos devido a umidade excessiva. Foram identificados riscos ergonômicos relacionados ao levantamento e transporte manual de peso.

Na Figura 6 é possível observar peças cujo os pesos não são suportados apenas por uma pessoa como a fôrma de concreto para adorno do muro e rolo de manta impermeabilizante. Esses materiais ficam localizados no ponto mais distante da saída, exigindo maior esforço e maior número de pessoas para remove-los. Isso foi caracterizado como risco ergonômicos elevado. 
Figura 6 - Objetos de peso elevado localizados nos fundos do almoxarifado.

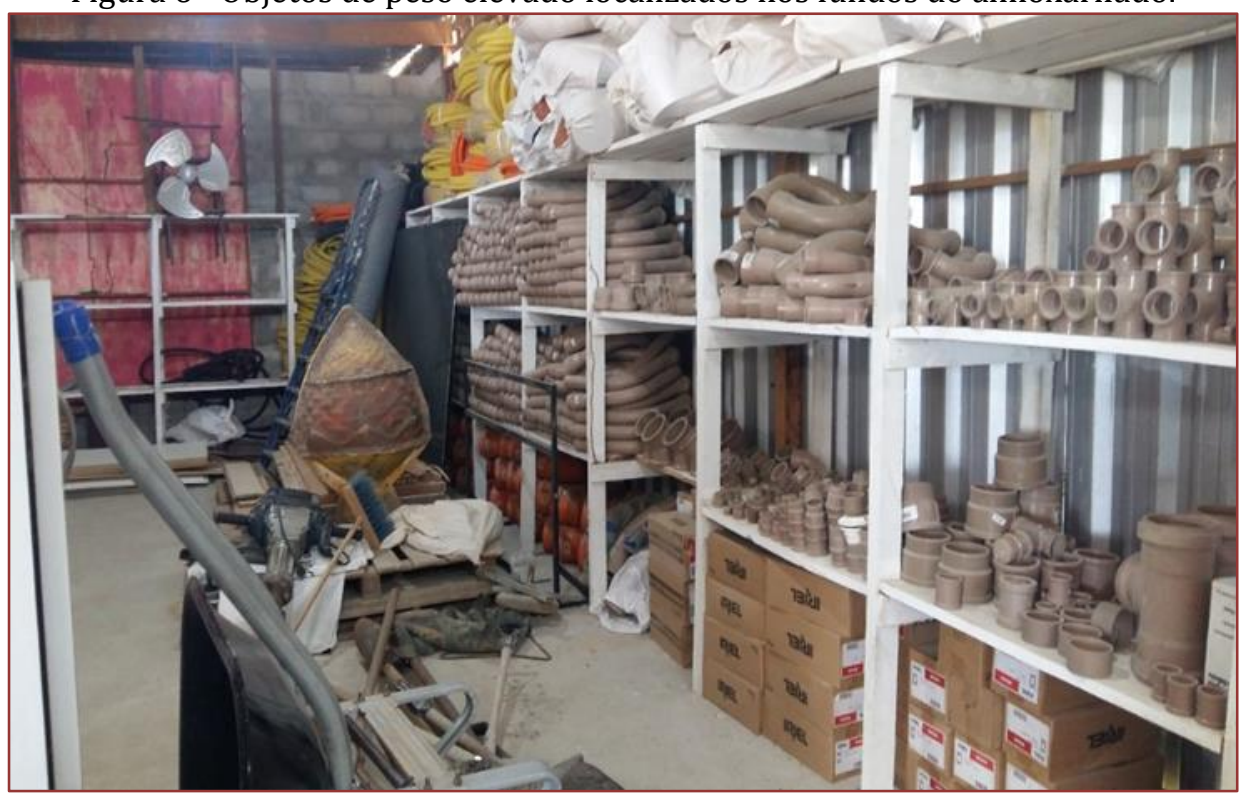

Fonte: Autoria Própria, 2020.

Ainda foram identificados risco ergonômicos de intensidade média por exigir o esforço maior para remover alguns materiais. 0 risco ergonômico médio identificado e representado no mapa de risco da Figura 7 corresponde a dois ventiladores usados na ventilação do refeitório, os quais exige esforço de duas pessoas. No entanto a sua locomoção era eventual.

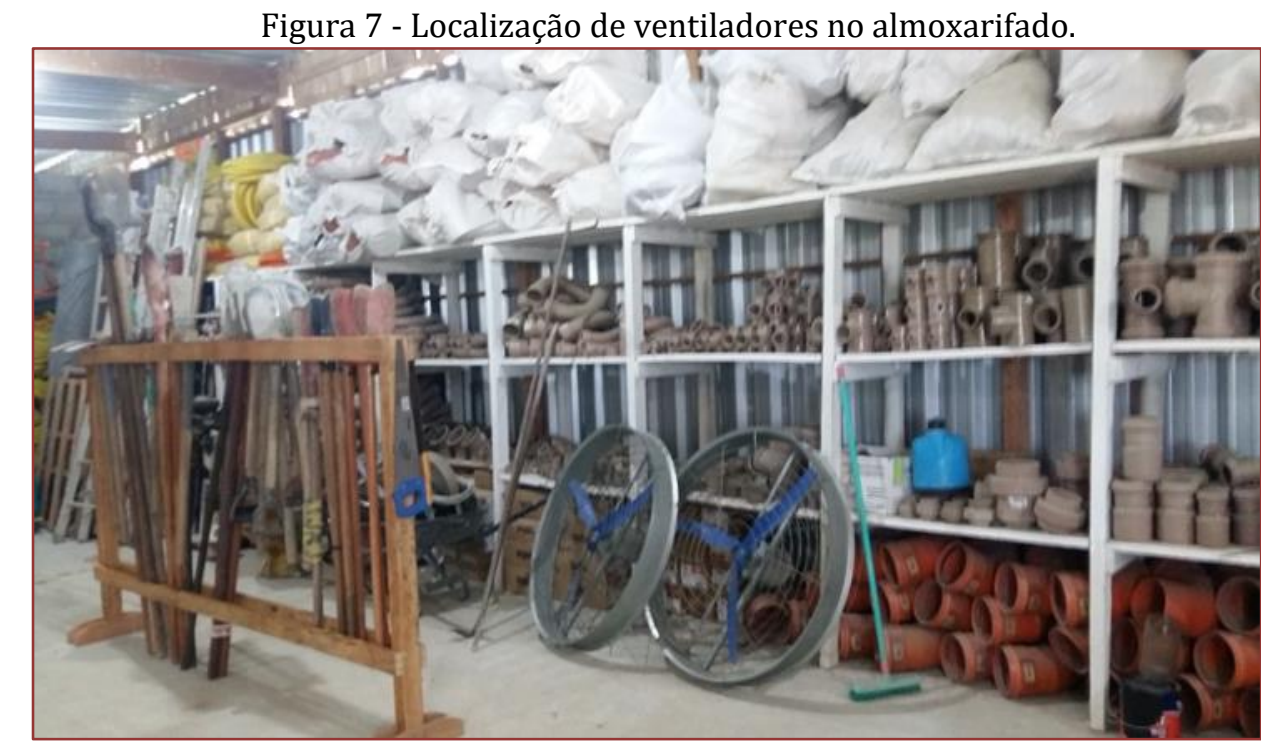

Fonte: Autoria Própria, 2020.

A localização de peças pesadas em prateleiras a cima da cabeça do trabalhador pode causar problemas ergonômicos. Na Figura 8 é possível observar armazenamento de peças pesadas como a coluna de um lavatório na última prateleira. Tal situação foi identificada como risco ergonômico leve. 
Figura 8 - Localização de materiais no interior do almoxarifado

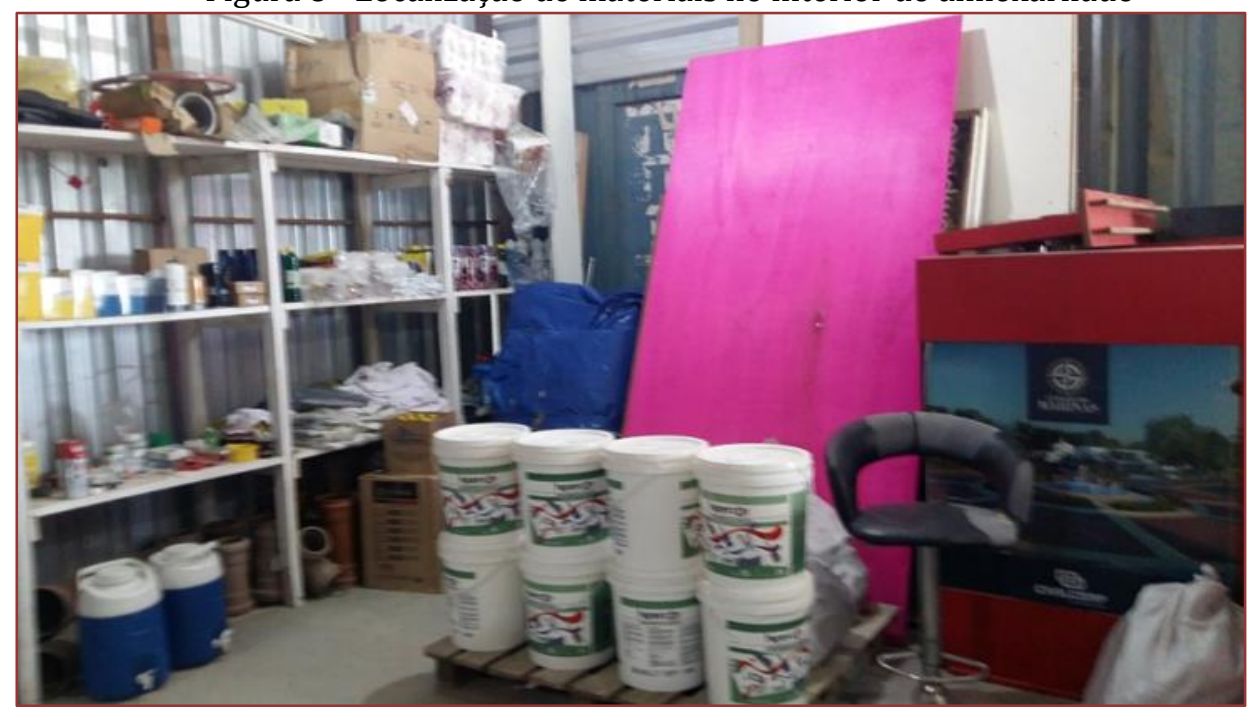

Fonte: Autoria Própria, 2020

Entre o risco de acidentes identificados no mapa de risco a presença de combustível foi identificada como intensidade elevada devido a probabilidade de incêndio ou explosão. Na Figura 9 é possível identificar o armazenamento inadequado de combustível no interior do almoxarifado.

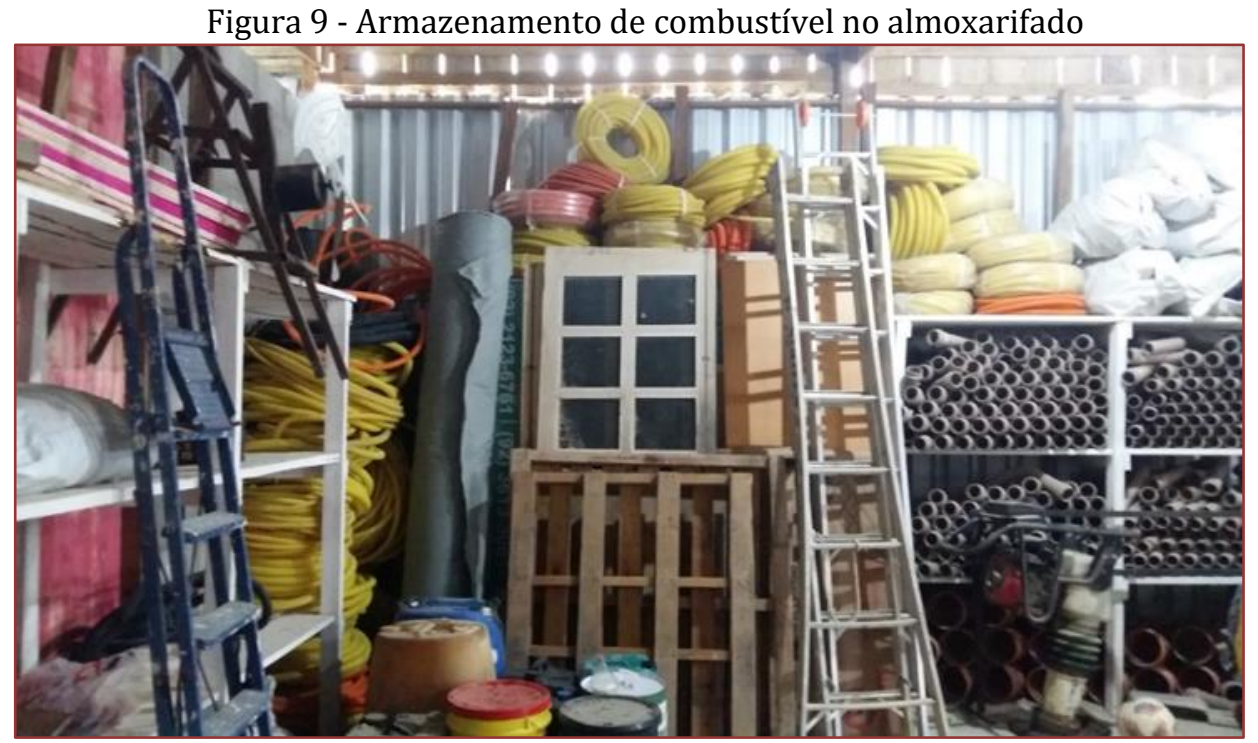

Fonte: Autoria Própria, 2020

Do outro lado do almoxarifado foi identificado a localização inadequada de extintor de incêndio, o que caracteriza risco de acidente médio. Na Figura 10 observa-se que os extintores estão no piso e com o acesso restrito devido o acumulo de materiais diversos. 


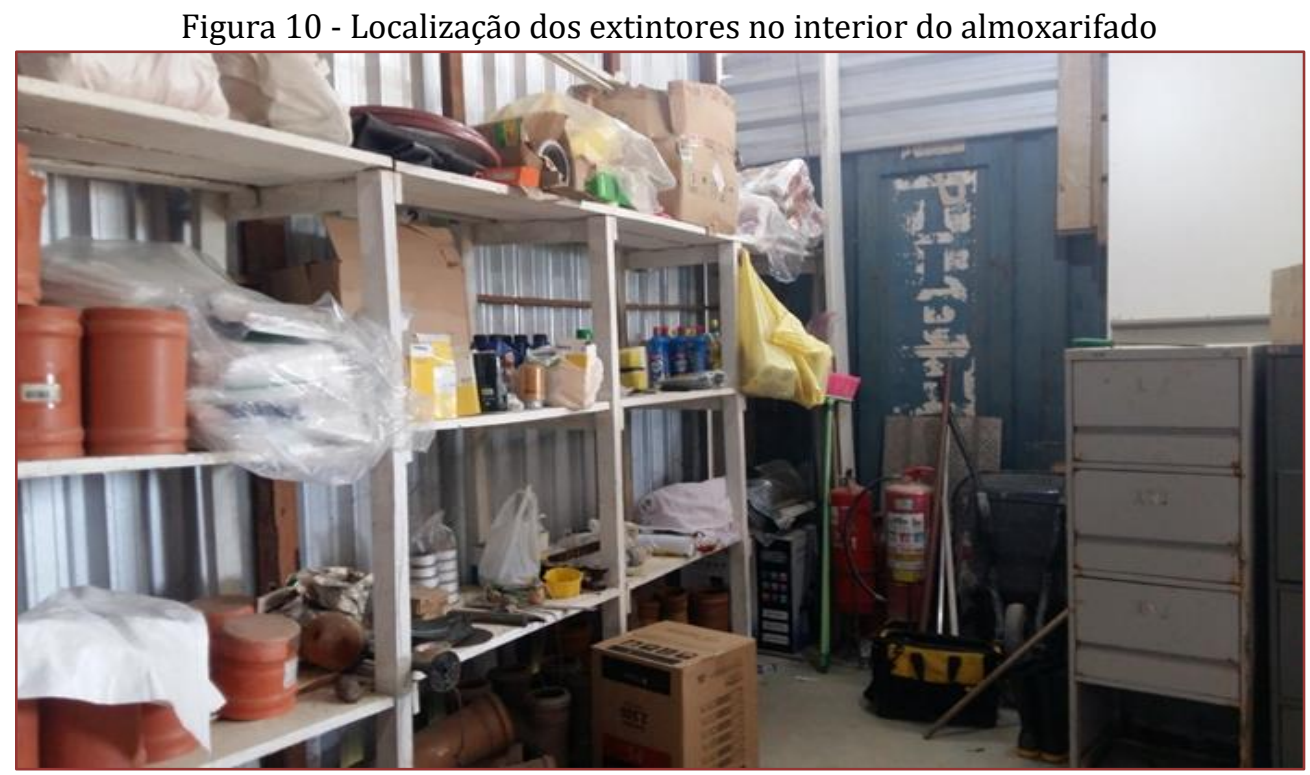

Fonte: Autoria Própria, 2020

0 risco de acidente neste almoxarifado é evidente devido à localização inadequada de materiais como pode ser observado na Figura 11. A armazenagem de tubos no piso do almoxarifado obstruindo o fluxo dos materiais no interior do almoxarifado oferece risco de acidente médio.

Figura 11 - Posicionamento inadequado de materiais no interior do almoxarifado.

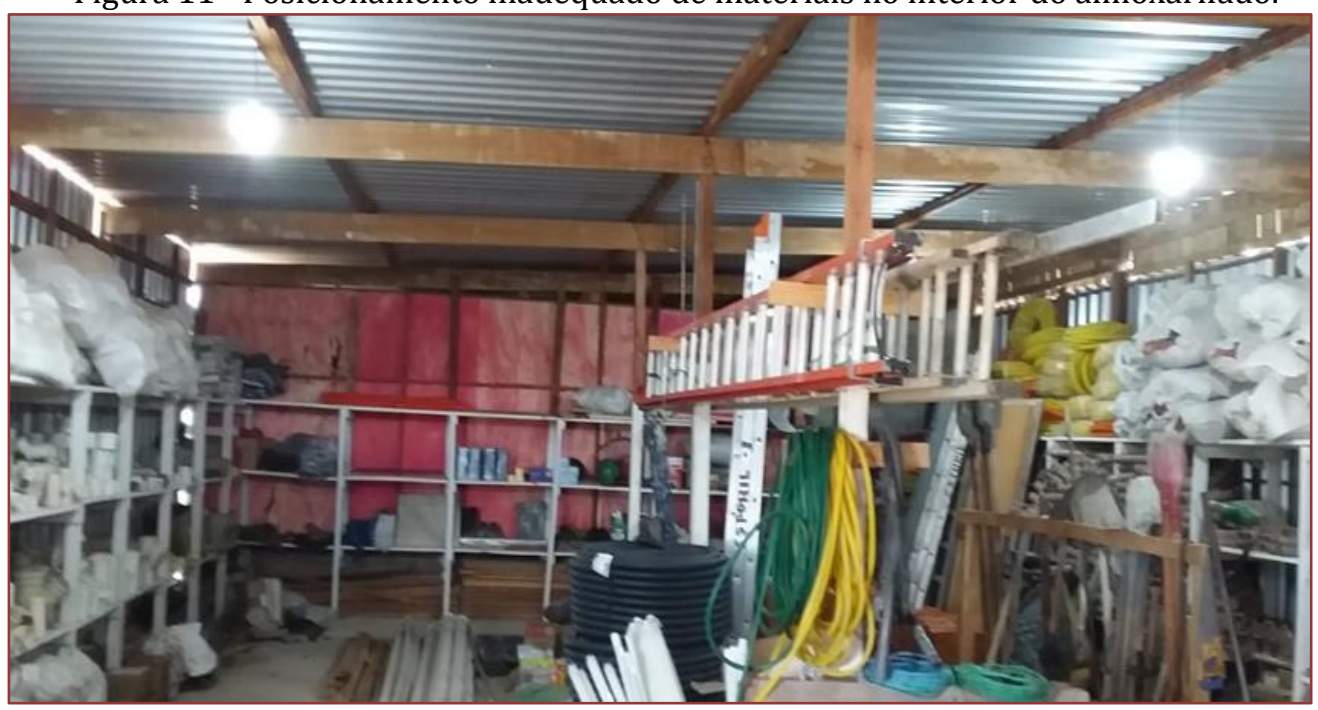

Fonte: Autoria Própria, 2020.

Baseada na análise dos riscos foi possível identificar que a armazenagem inadequada dos materiais oferece mais risco de acidente e ergonômico. Para eliminar os riscos de acidente é necessário que seja retirado materiais que obstruem a movimentação do interior do almoxarifado.

\subsection{ANÁLISE DO FLUXO E MOVIMENTAÇÃO NO INTERIOR DO ALMOXARIFADO}

Baseado na análise dos riscos de acidentes identificados no mapa de risco, os riscos ergonômicos foram um dos de maior incidência. Entre os riscos ergonômicos existentes foram avaliados os riscos físicos. Os riscos ergonômicos físicos foram caracterizados de acordo com a NR 17, na qual especifica as condições de trabalho que envolve levantamento, transporte e descarga de materiais entre outras condições que interfere nas características psicofisiológicas dos trabalhadores. Essas condições foram avaliadas por meio de elaboração de fluxogramas das principais atividades realizadas pelo trabalhador no almoxarifado. Para 
análise das atividades de levantamento de transporte e descarga foram identificadas a movimentação dos materiais que mais tinham saída no período avaliado da obra. Os materiais que tinham mais saída eram cimento, tinta, conduíte e ferramentas. Na Figura 12 estão representados os fluxogramas dos materiais de maior saída do almoxarifado.

Figura 22 - Fluxograma do descarregamento do cimento (a), tinta (b), conduíte (c) e ferramenta (d)

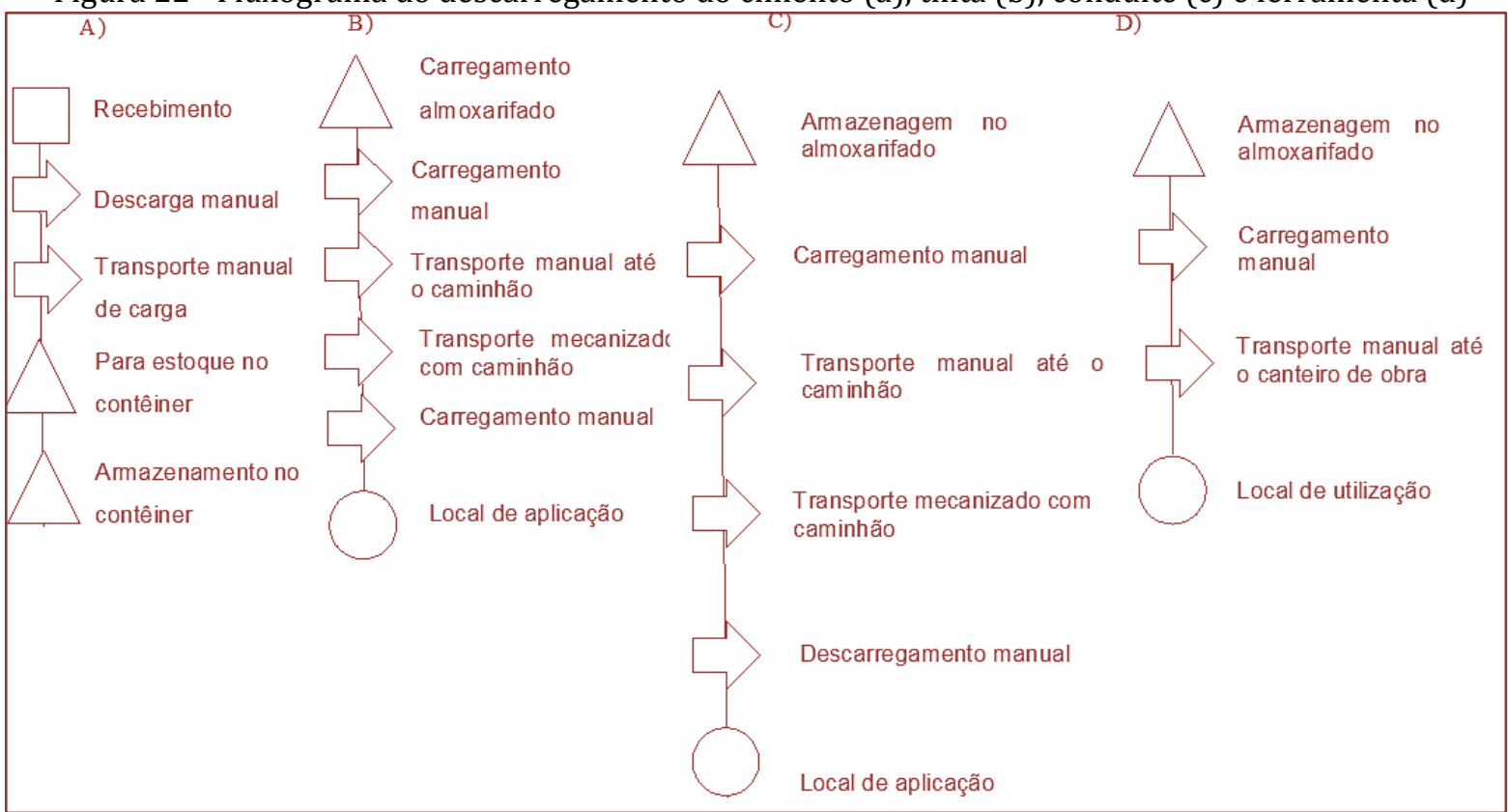

Fonte: Autoria Própria, 2020

É possível observar nos fluxogramas um número maior de movimentação e transporte. Isso pode ser atribuído tanto a organização dos materiais no almoxarifado quanto na sua localização no canteiro de obras. A obra era abastecida com cimento geralmente duas vezes na semana. Cada lote continua em média 300 unidades de saco de cimento. Os sacos eram armazenados em um contêiner ao lado do almoxarifado com acesso independente como pode ser visto na Figura 13.

Figura 33 - Localização do contêiner para armazenagem do cimento

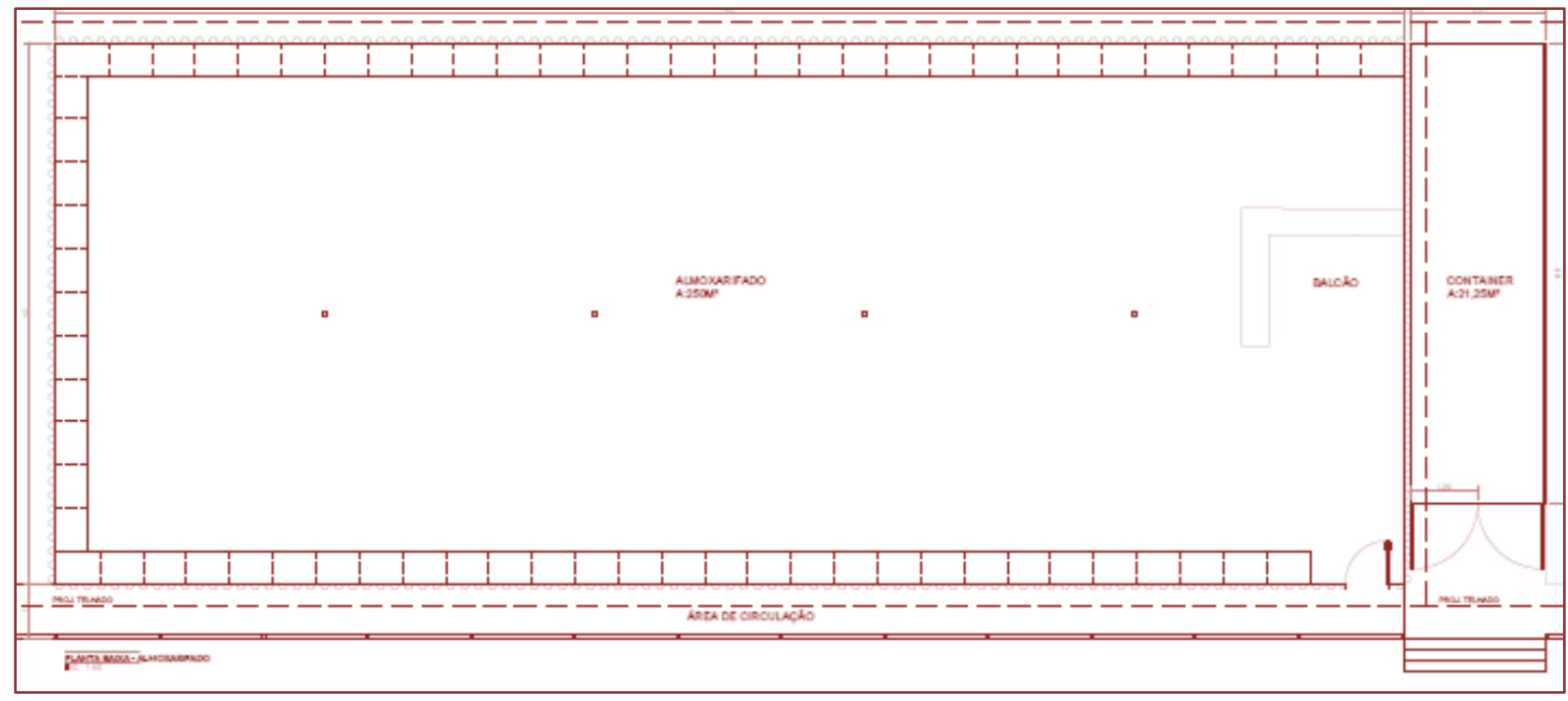

Fonte: Autoria Própria, 2020

Os sacos eram armazenados no interior do contêiner conforme a Figura 14. 0 armazenamento do cimento era feito conforme a norma NBR 16697 (ABNT, 2018). 
Figura 44 - Estocagem do cimento no interior do contêiner

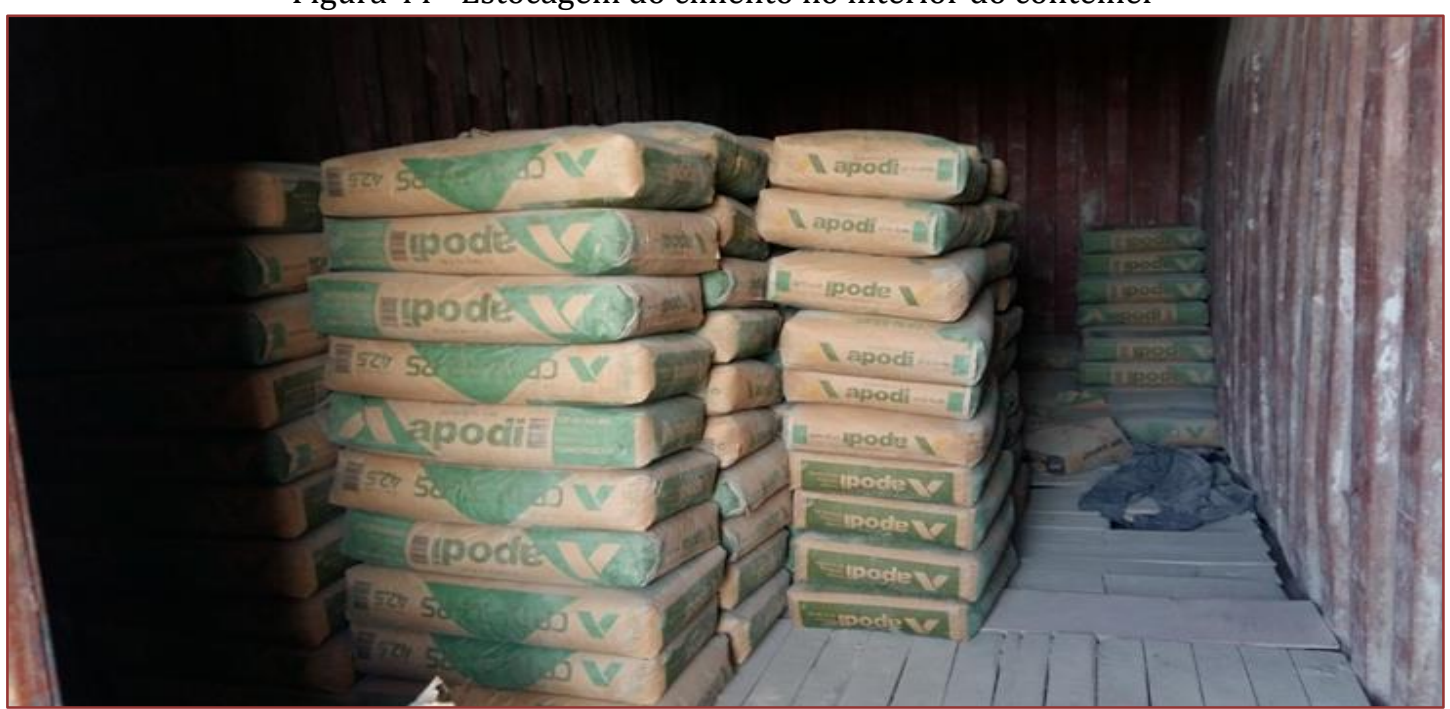

Fonte: Autoria Própria, 2020

Como representado no fluxograma (a) o caminhão carregado de cimento era descarregado manualmente pelos operários sendo que este se posicionava na entrada do contêiner como pode ser vista na Figura 15. Esse descarregamento era realizado por um operário localizado na carroceria do caminhão que repassava os sacos um a um para os operários que levavam os sacos na cabeça até o centro do contêiner.

Figura 55 - Acesso à entrada do contêiner para descarregamento do cimento

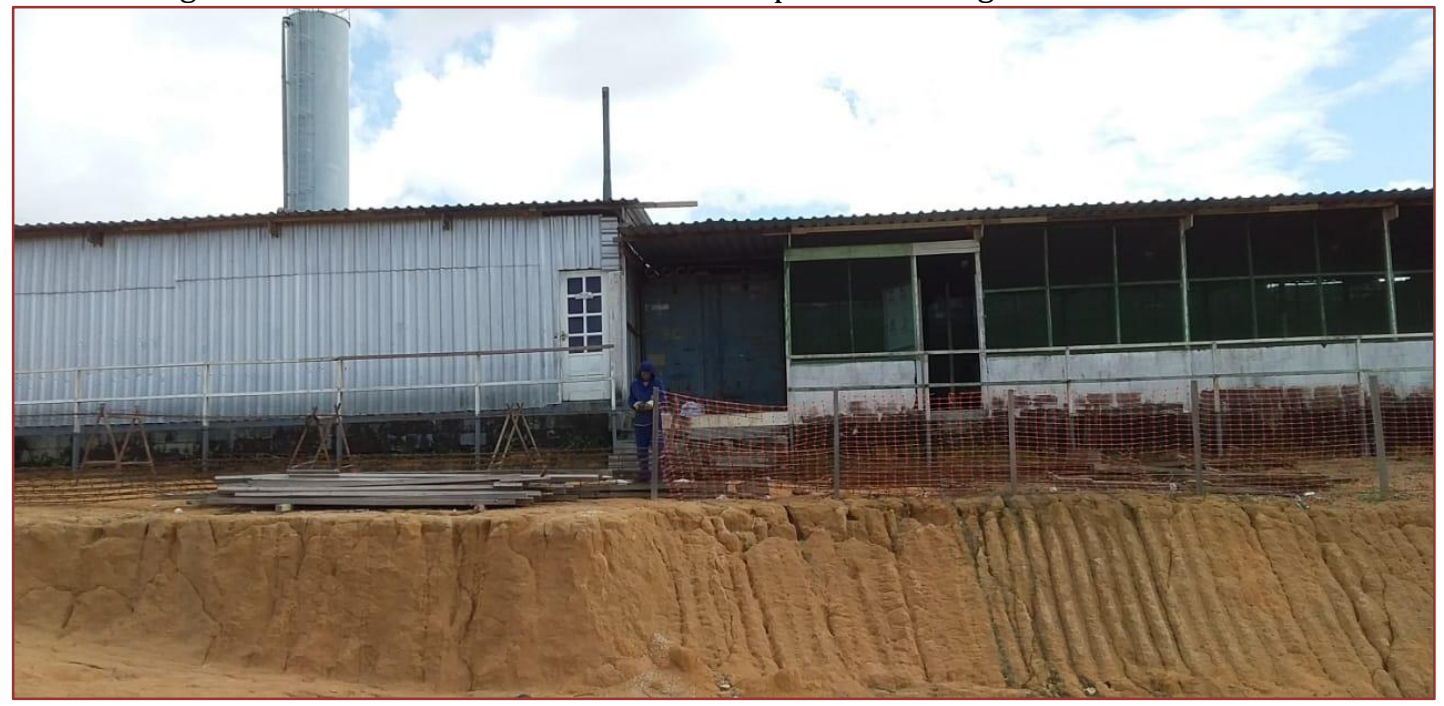

Fonte: Autoria Própria, 2020

Para a NR 17 (ABNT, 1978) o transporte manual de carga não pode ser feiro por um trabalhador cujo o peso comprometa a sua saúde ou a sua segurança. Ainda recomenda que o transporte manual de carga deva ser feito usando meios que limite ou facilite esse meio de transporte.

No fluxograma (b) e (c) é possível identificar transporte manual também, porém de materiais mais leve que o cimento. 0 transporte até o local de aplicação desses materiais, incluindo o cimento, era feito por caminhão cujo o percurso está indicado na Figura 16. No entanto, o descarregamento desses materiais de aplicação era manual, realizado repetidamente todas as vezes que era necessário o abastecimento. 
Figura 66 - Percurso do material até o local de aplicação

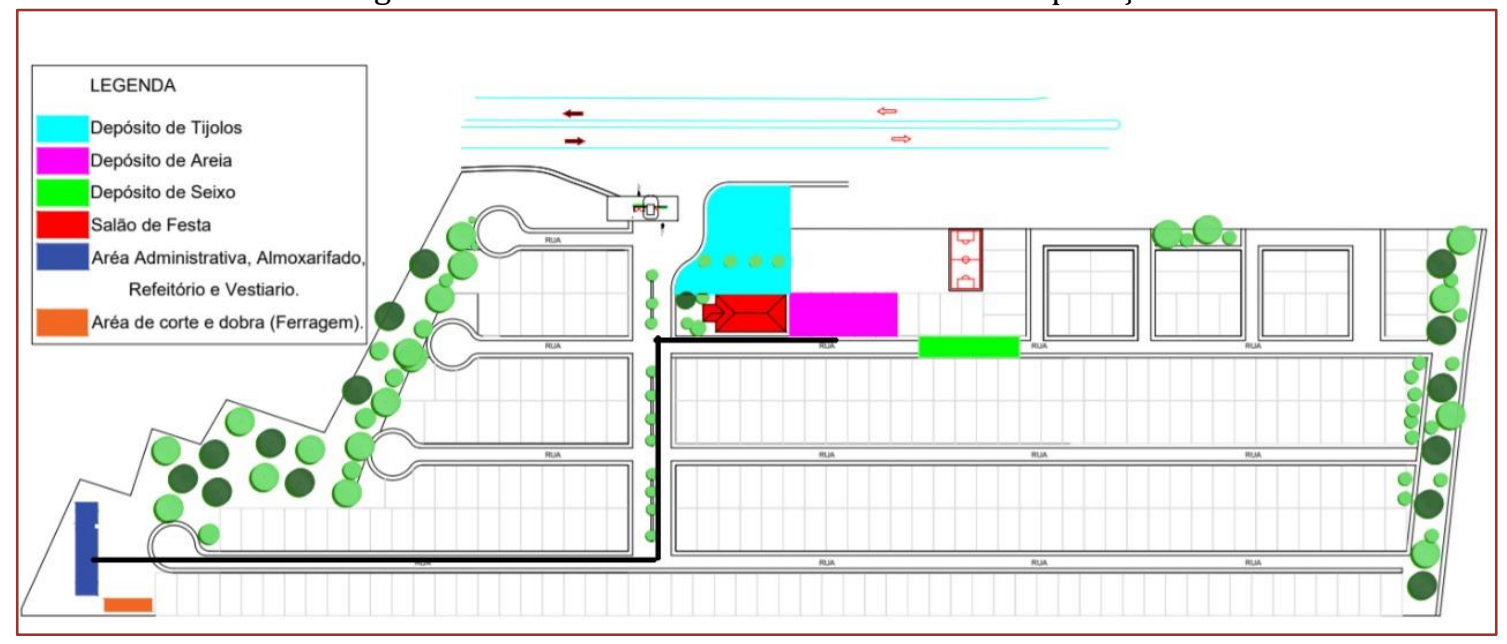

Fonte: Autoria Própria, 2020

O fluxograma (d) que se refere ao fluxo de ferramenta indica que o transporte até o local de trabalho era realizado a pé. 0 percurso até o local de trabalho é o mesmo indicado na Figura 16. Os riscos ergonômicos físicos relacionados ao transporte dessas ferramentas.

\subsection{O USO DE FERRAMENTAS DO BIM 8D NO ESTUDO DE CASO}

O canteiro de obras, independentemente do tipo de construção, oferece inúmeros riscos nos quais ainda são gerenciados de forma intuitiva. A avaliação dos riscos depende muito da experiência e muitas vezes não produz tomada de decisões eficiente na pratica de um profissional. Visando identificar de forma precoce os riscos, auxiliar na prevenção de acidentes e na comunicação dos riscos o BIM vem sendo utilizado.

O gerenciamento adiciona a informação da construção civil usa para o gerenciamento de riscos das ferramentas como: Modelo 3D, verificação automática de regras, sistema baseado em conhecimento, realidade virtual, modelagem 4D, sistema de georeferenciamento, GPS, digitalização a laser e identificação por radiofrequência. A seguir é apresentado para o estudo de caso a possível utilização dessas ferramentas na identificação dos riscos. No BIM o uso do modelo 3D ajuda na identificação dos riscos de segurança ainda no planejamento da obra. Essa ferramenta é essencial para implementação de BIM em qualquer dimensão. Com auxílio da modelagem 4D é possível detectar automaticamente conflitos no arranjo físico do almoxarifado. Essas ferramentas podem gerar vídeos curtos ou visualizações automáticas simulando a visão de uma pessoa caminhando no interior do almoxarifado.

Na Figura 17 e 18 está representada uma visão do interior do almoxarifado feita no programa Revit@. É possível observar a área central do almoxarifado livre, permitindo visualizar os materiais na prateleira. Essa área central desimpedida favorece uma redução no fluxo de movimentação do operário para localizar os materiais. Por se tratar da imagem gerada em software 3D do interior do almoxarifado com a localização dos extintores, a imagem dos extintores é representada no centro do interior do almoxarifado. Foi feito uma possível identificação dos extintores no programa do Revit®. 
Figura 77 - Imagem gerada em software 3D do interior do almoxarifado

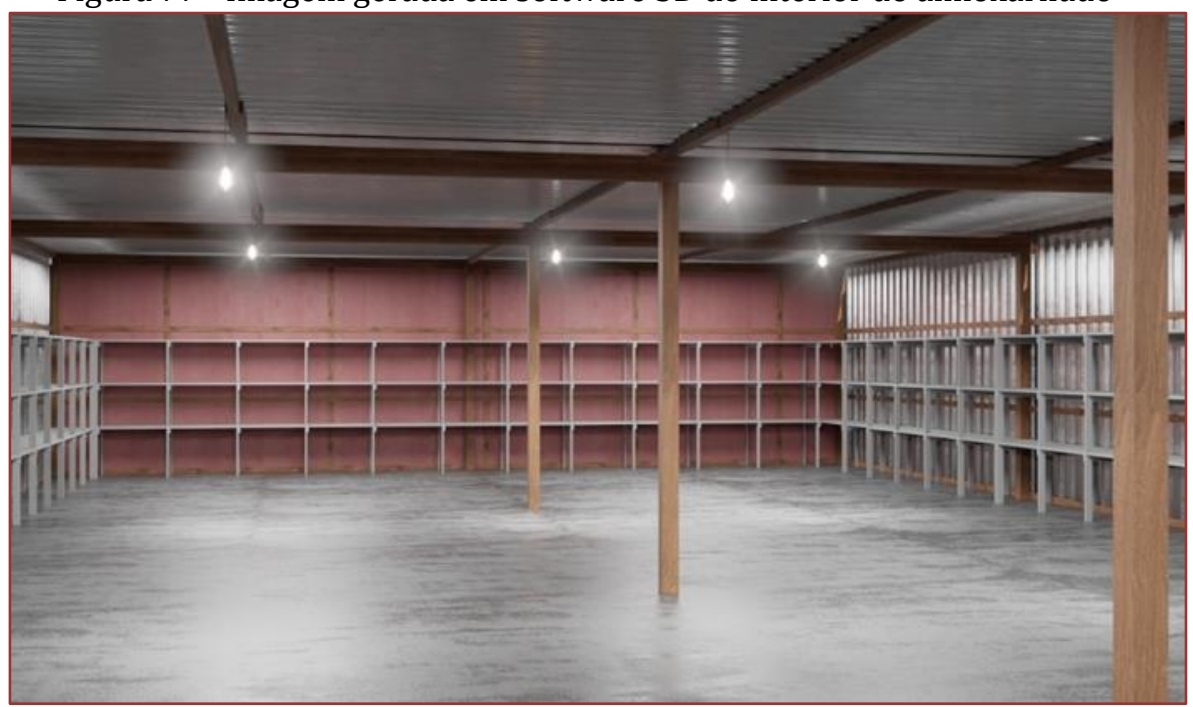

Fonte: Autoria Própria, 2020

Figura 188 - Imagem gerada em software 3D com a localização dos extintores

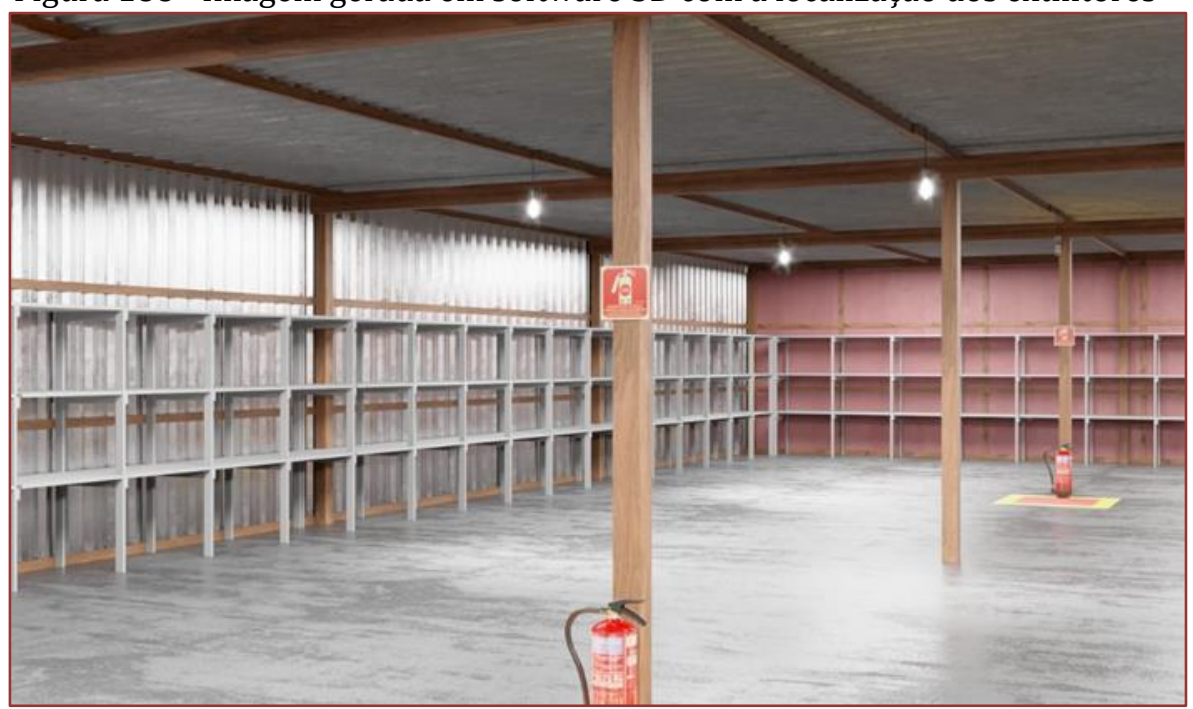

Fonte: Autoria Própria, 2020

Na Figura 19 está representada outra visão do interior do almoxarifado com a qual é possível simular rota de fuga. Esse recurso gráfico permiti fazer alterações no modelo de forma rápida.

Por se tratar de um modelo paramétrico esse modelo gráfico permite uma representação gráfica interoperavel. Isso significa que esse modelo gráfico e as alterações que são feitas nele pode ser facilmente reconhecida por outras ferramentas do BIM como na modelagem 4D e 5D. 
Figura 19 - Imagem gerada em software 3D da saída do almoxarifado

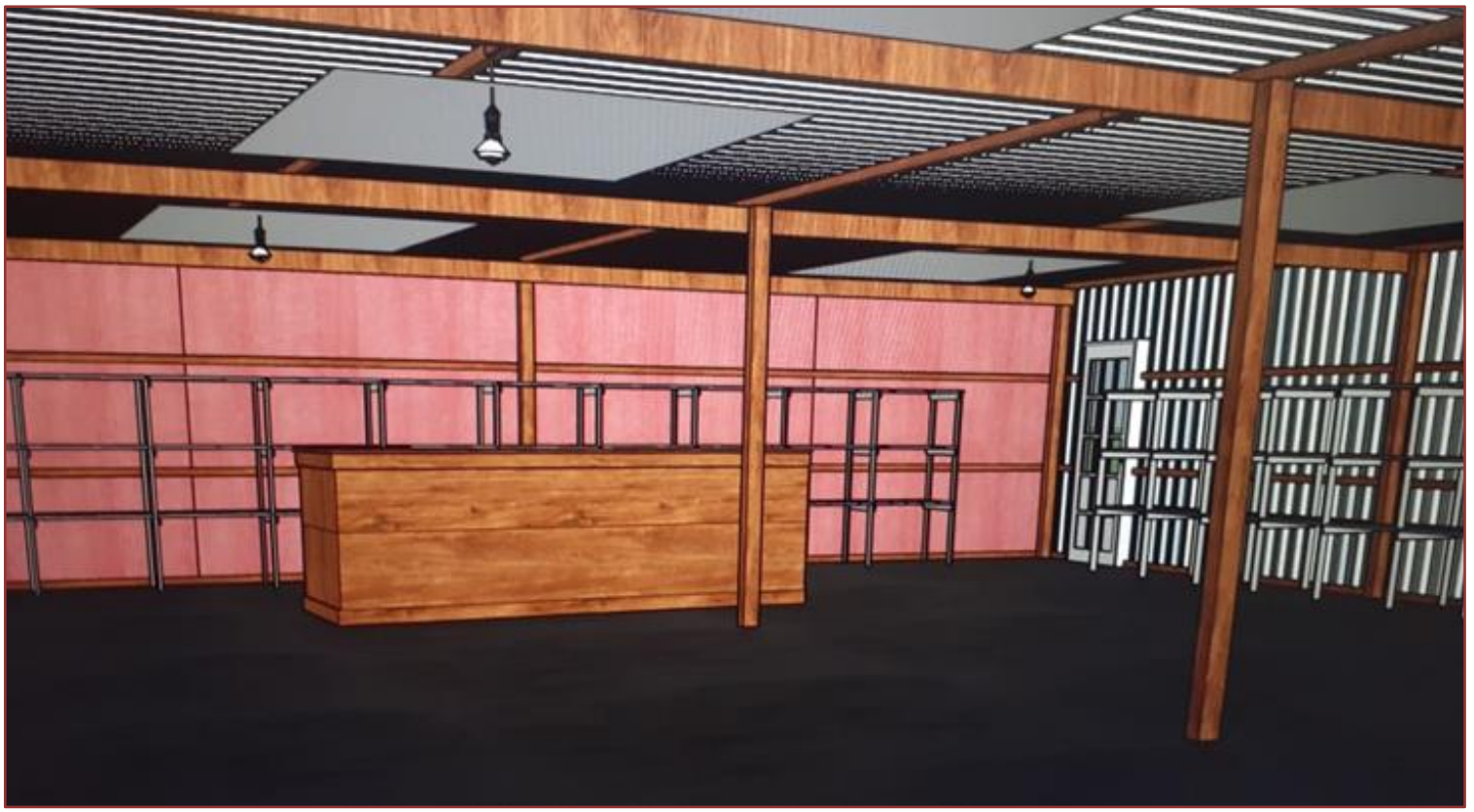

Fonte: Autoria Própria, 2020

As informações do modelo 3D permitem gerar dados para ferramentas de tecnologia de informação (TIC) que ajudam o engenheiro a formular regras para identificar riscos. Isso é possível com uso de banco de dado baseado em conhecimento, o qual armazena informações de outros projetos quanto a situações de riscos. Assim é possível utilizar programas de regras para identificar risco de segura durante o planejamento da obra. Com um programa de verificação automáticas de regras, por interpretação de códigos, avalia-se o projeto quanto aos riscos emitindo respostas como: "Aprovado, Reprovado, Aviso ou Desconhecido".

Com relação ao estudo de caso poderia ser adotado um programa de verificação que alimentado com informações quanto ao tipo de risco oferecido pelo armazenamento de materiais no interior do almoxarifado, orientar quanto à disposição adequada desses materiais e os riscos que oferece. Poderiam ainda informar os materiais que não poderiam ser armazenados em um almoxarifado. Esse tipo de verificação poderia ainda, baseado em algoritmos de convenção de regras de segurança, visando proteção conta quedas por exemplo, planejar e simular problemas de segurança. Essas verificações poderiam ainda auxiliar na avaliação dos fluxos dos movimentos no transporte de materiais.

0 uso de realidade virtual auxilia no treinamento dos funcionários no local de trabalho permitindo identificar risco de segurança. É possível ainda simular situações de perigo ajudando na formulação de estratégia e medidas de prevenção ou até mesmo avaliação do risco. Para auxiliar na montagem dos cenários, Guo et al. (2013) propuseram adotar prototipagem virtual. A prototipagem virtual é composta com três componente: Modelagem e simulação, identificação de fatores inseguros e treinamento. A realidade virtual integrada a bancos de dados permite gerenciar os riscos de segurança em outras construções.

O sistema de georeferenciamento integrado a um sistema baseado em conhecimento ajuda a monitorar e controlar os riscos de segurança. No estudo de caso as coordenadas georefenciadas ajudariam na modelagem da topografia, analise geoespacial e na geração e atualização do planejamento. Gerando modelo 3D mais realista do local as coordenadas georefenciadas ajudariam na programação dos serviços buscando ambientes seguros.

Um sistema de prevenção de obstáculos baseado no modelo 3D construído a partir de nuvem de pontos (digitalização à laser) é possível modelar objetos ou zonas estáticas que oferece riscos. Esses sistemas podem ser instalados em máquinas como guindastes e retroescavadeiras que integrados a tecnologia de identificação por radiofrequência e GPS ajudam a detectar em tempo real perigo não visualizados devido a pontos cegos. Os sistemas ainda podem sinalizar quando uma atividade proibida está sendo executada. No estudo de caso esse recurso poderia auxiliar na identificação de transporte de pessoas que oferece risco, por exemplo na carroceria do caminhão. 


\subsection{ROTEIRO DE IMPLEMENTAÇÃO DE MODELO BIM 8D DE UM ALMOXARIFADO}

Baseado no estudo de caso foi possível identificar que para implementação do BIM 8D em canteiro de obra alguns requisitos são essenciais. No Quadro 2 são apresentados os requisitos necessários para implementação do BIM 8D no canteiro de obra.

Quadro 2 - Implementação do BIM 8D

\begin{tabular}{|c|c|}
\hline Requisitos & Ferramentas \\
\hline Construção do modelo virtual & Programas de modelagem 3D \\
\hline Pensar no processo de execução & Programas de planejamento 4D \\
\hline Análise previa dos riscos & Mapeamento de fluxo \\
\hline Simulação & Programa de planejamento 4D \\
\hline Análise do custo & Programa de modelagem 5D \\
\hline Identificação dos riscos controlados & A escolha \\
\hline
\end{tabular}

Fonte: Autoria Própria, 2020

A construção do modelo virtual é um requisito para a implementação do BIM 8D por conter informações que serão importantes para o nível de detalhamento na dimensão 8D. Para isso nesse estágio é necessário definir o nível de detalhamento dos objetos inseridos no modelo 3D. As informações sobre os objetos para dimensão 8D devem ser completas, pois isso vai permitir usar essas informações no gerenciamento de riscos. Esse nível de especificação ou detalhamento é chamado de LOD. O LOD para a implementação do BIM 8D é da ordem LOD 400. No LOD 400 as informações sobre os elementos são quantos as dimensões, material, fabricante e modelo.

Para implementar a dimensão 8D são necessárias 4D e 5D. A dimensão 4D precisa de informações precisas sobre o método construtivo do canteiro de obras. Decisões como adotar método construtivo convencional ou modular impacto no prazo, no custo e no gerenciamento de risco. Nesta dimensão todas as incompatibilidades de projeto devem ser resolvidas, isso contribui também para prevenção de acidentes. Pensar no processo construtivo ajuda na prevenção de acidentes utilizando a ferramenta de mapeamento de fluxo para melhor análise dos riscos. Desta forma é possível identificar as atividades que causam riscos ergonômicos sendo possível ainda fazer simulações com modelo virtuais de realidade aumentada ou realidade virtual. Essas simulações ajudam ainda nos treinamentos e na conscientização da mão de obra dos trabalhadores quanto aos riscos inerentes do canteiro de obra.

Com as eliminações dos riscos identificadas nas simulações é necessário ainda avaliar os custos. Na dimensão 5D de forma integrada e simultânea, permitindo análise do ponto de vista estratégico quanto a organização do canteiro. Dessa forma a tomada de decisão para o uso de tecnologia BIM 8D de gerenciamento de risco torna-se mais eficaz. A partir desse instante o uso das ferramentas 8D apresentadas na sessão anterior é definido de forma mais assertiva.

\section{CONCLUSÃo}

0 estudo de caso realizado nesse trabalho apresentou evidencias da dependência da experiência dos gestores no gerenciamento de riscos. A organização do canteiro foi elaborada reproduzindo o arranjo de canteiro de outras obras. Foi possível observar no mapa de risco e nos fluxogramas de atividades de movimentação dos materiais que a organização do canteiro não foi pensada para prevenção de acidentes.

0 uso de ferramentas para o gerenciamento de risco dentro do conceito de BIM ainda aparece muito fora da realidade. As informações e nível de detalhamento dos projetos tornam-se ainda mais relevante no gerenciamento de risco no canteiro de obras. Ainda é necessário que se faça uma aplicação maior dessa tecnologia para que sejam uma realidade possível em canteiro de obras.

Entre os requisitos necessários para implementação de BIM na dimensão 8D deve ser destacado o estudo do processo construtivo como fundamental para o uso dessas tecnologias. As vantagens da implementação do BIM 8D são evidentes principalmente por permitir melhor controle dos riscos. Porém a implementação de BIM 8D exige treinamento de pessoas tanto nas ferramentas quanto no gerenciamento de risco. 
Portanto, a recomendação de ferramentas do BIM 8D na organização de canteiro de obras para prevenção de acidentes só é válida se as dimensões 3D,4D e 5D forem implementadas com êxito. Sendo assim uma vez implementadas o gerenciamento de risco utilizando as ferramentas da dimensão 8D torna-se mais eficaz.

\section{REFERÊNCIAS}

[1] Ahmad, Zubair; Thaheem, Muhammad Jamaluddin; Maqsoom, Ahsen. Building information modeling as a risk transformer: An evolutionary insight into the project uncertainty. Automation in Construction, Volume 92, 2018, Pages 103-119, ISSN 0926-5805, https://doi.org/10.1016/j.autcon.2018.03.032.

[2] ASSOCIAÇÃO BRASILEIRA DE NORMAS TÉCNICAS. NBR 6027: informação e documentação: sumário: apresentação. Rio de Janeiro,2012.

[3] ASSOCIAÇÃO BRASILEIRA DE NORMAS TÉCNICAS. NBR 6028: informação e documentação: resumo: apresentação. Rio de Janeiro, 2003.

[4] ASSOCIAÇÃO BRASILEIRA DE NORMAS TÉCNICAS. NBR 14724: informação e documentação: trabalhos acadêmicos: apresentação. Rio de Janeiro, 2011.

[5] Bourhim, EL Mostafa; Cherkaoui, Abdelghani. Efficacy of Virtual Reality for Studying People's Pre-evacuation Behavior under Fire. International Journal of Human-Computer Studies, Volume 142, 2020, 102484, ISSN 1071-5819, https://doi.org/10.1016/j.ijhcs.2020.102484.

[6] CARVALHO, Dayvson. Plataforma Bim: Tudo sobre a grande tendência da construção. Sienge plataforma, 11 set. 2017. Disponível em: http://www.sienge.com.br/blog/plataforma-bim. Acesso em: 29 jan. 2020.

[7] GARIBALDI, Bárbara Cristina. Do 3D ao 7D - Entenda todas as dimensões do Bim. Sienge plataforma, 08 jan. 2020. Disponível em: http://www.sienge.com.br/blog/dimensões-do-Bim/ Acesso em: 14 jan. 2020.

[8] GUO, Hongling; YU RUN; FANG, Yihai. Analysis of negative impacts of BIM-enabled information transparency on contractors' interests. Automation in Construction, Volume 103, 2019, Pages 67-79, ISSN 0926-5805. https://doi.org/10.1016/j.autcon.2019.03.007.

[9] HEATON, James; PARLIKAD, AJITH KUMAR, Jennifer Schooling. A Building Information Modelling approach to the alignment of organisational objectives to Asset Information Requirements. Automation in Construction, Volume 104, 2019, Pages 14-26, ISSN 0926-5805, https://doi.org/10.1016/j.autcon.2019.03.022.

[10] INSTITUTO BRASILEIRO DE GEOGRÁFIA E ESTATíSTICA. Normas de apresentação tabular. 3.ed. Rio de Janeiro, 1993.

[11] Kim, D., Lee, S., \& Kamat, V. R. Proximity prediction of mobile objects to prevent contact-driven accidents in co-robotic construction. Journal of Computing in Civil Engineering, 34(4), 2020. doi:10.1061/(ASCE)CP.19435487.0000899 .

[12] LIMA, Tomás. Análise de riscos na construção civil. Sienge plataforma, 16 agost. 2017. Disponível em: http://www.sienge.com.br/blog/riscos-construção-civil. Acesso em: 20 jan. 2020

[13] LIMA, Tomas. As dores do gerenciamento de empreiteiros e como trata-las. Sienge Plataforma, 01 mai. 2019. Disponível em: http://www.sienge.com.br/blog/dores-de-gerenciamento-de-empreiteiros. Acesso em: 14 jan. 2020.

[14] MARCONDES, Aníbal. Uma breve história do gerenciamento de projetos. Disponível em: http://www.pmimt.org.br/site/index;php/artigo/vis/4. Acesso em: 01 fev.2020.

[15] Rahimian, Farzad Pour; Seyedzadeh, Saleh, Oliver, Stephen, Rodriguez, Sergio; Dawood, Nashwan. Ondemand monitoring of construction projects through a game-like hybrid application of BIM and machine learning. Automation in Construction, Volume 110, 2020, 103012, ISSN 0926-5805, https://doi.org/10.1016/j.autcon.2019.103012.

[16] Roshana Takim, Muhammad Hanafi Zulkifli, Abdul Hadi Nawawi. Integration of Automated Safety Rule Checking (ASRC) System for Safety Planning BIM-Based Projects in Malaysia. Procedia - Social and Behavioral Sciences, Volume 222, 2016, Pages 103-110, ISSN 1877-0428, https://doi.org/10.1016/j.sbspro.2016.05.195.

[17] SAMPAIO, Allefy Teles; LAVEZO, Ana Elisa. COUTINHO, Graziella Deldoto. Segurança do trabalho e medidas de proteção na construção civil. Braz. J. of Develop., Curitiba, v. 6, n. 3, p. 9983-9997 mar. 2020. ISSN 2525-8761.

[18] BRASIL. MINISTÉRIO DA ECONOMIA. SECRETARIA DO TRABALHO. www.trabalho.gov.br/seguranca-esaude-notrabalho/normatizacao/normas-regulamentadoras. (Acesso: 23/06/2020).

[19] SILVA, Adriano Anderson. Segurança no trabalho na construção civil: Uma revisão bibliográfica, Belo Horizonte, Revista pensar engenharia, v.1, n.1, jan. 2015. Disponível em: http://www.revistapensar.com.br/engenharia/ pasta_upload/artigo/a144.pdf/ Acesso em: 18 jan. 2020. 
[20] SOUZA, Manuela. Bim: Revolucionando a construção. Revista da Anicer, Rio de Janeiro, Anicer, n.115, maio/2019. Disponível em: http://www.anicer.com.br/revista-anicer/revista-115 Acesso em: 13 jan. 2020.

[21] VASCONCELOS PFL, Lemos AS, Medeiros RK. EFICÁCIA DO GERENCIAMENTO E PLANEJAMENTO NA CONSTRUÇÃO CIVIL. Anais do 17 Simpósio de TCC e 14 Seminário de IC do Centro Universitário ICESP. 2019 (17); 995-1003.

[22] YANG Zou, Arto Kiviniemi, Stephen W. Jones. A review of risk management through BIM and BIM-related technologies. Safety Science, Volume 97, 2017, Pages 88-98, ISSN 0925-7535, https://doi.org/10.1016/j.ssci.2015.12.027. 


\section{Capítulo 3}

\section{Construção enxuta e seus benefícios para a construção Civil em tempos de crise}

\section{Leila Macedo da Silva}

Bianca Guimarães Pedrosa

\section{Luciane Farias Ribas}

Sara Santarém

Resumo: 0 presente estudo propõe-se a abordar a construção enxuta e seus benefícios para a construção civil em tempos de crise, buscando através de pesquisas bibliográficas de forma qualitativa e quantitativa. Após uma visita à fábrica Ford realizada pelos engenheiros Eiji Toyoda e Taiichi Ohno, a produção enxuta começou a ser pensada dando início ao sistema Lean Manufacturing. Sua estratégia consistia em uma produção que buscasse melhorias contínuas em toda produção. A visão da montadora Toyota era uma produção baseada em uma nova dimensão de gestão de negócios como manufatura e desenvolvimentos de produtos, focando na eliminação de desperdícios e produzindo apenas o essencial. A partir da década de 80 surge a tendência de incorporação das ferramentas do modelo de produção Toyota no setor da construção civil. Diante disso, a pesquisa em questão tem o objetivo de analisar como o Lean Construction pode contribuir para o aumento da competitividade das construtoras na retomada pósquarentena, por meio de diagnóstico da situação e tomada de decisões, identificando as ferramentas adequadas. Foi realizado um levantamento do possível cenário do setor pós-pandemia, onde demonstrou que as empresas teriam como problema a redução de demanda, redução na produção e redução na mão de obra, ressaltando que a CE poderia aumentar a competitividade das empresas com melhoria nos processos, reduzindo perdas e eliminando atividades que não agregam valor, tornando o processo mais enxuto e mais fácil para programar as reduções na produção ou até mesmo em uma nova paralisação devido a quarentena causada pela disseminação da Covid-19.

Palavras chave: produção enxuta, Construção enxuta, Covid-9. 


\section{INTRODUÇÃO}

O presente estudo tem por objeto a investigação do que vem a ser o modelo de Construção Enxuta, quais seus propósitos e as possíveis vantagens que o modelo poderia representar em momentos de crise. A hipótese que se pretende demostrar é de que a adoção dos pressupostos da Construção enxuta representa importante instrumento para superação da crise que se apresentará no setor após as consequências econômicas da atual pandemia do Covid - 19.

Busca-se averiguar se a construção enxuta, pautada na incorporação das premissas do Sistema Toyota de Produção à construção civil, possibilitaria ganho de eficiência não apenas no contexto econômico, mas ainda no setor da saúde do trabalhador e dos custos sociais, tendo em vista a viabilidade da redução de acidentes de trabalhos e, assim, de gastos previdenciários como o afastamento doença e auxílio doença/acidente dos trabalhadores.

Neste contexto, o estudo percorrerá uma revisão documental-bibliográfica de fontes e doutrinas nacionais e internacionais, por meio da pesquisa qualitativa de doutrinas. Como corte epistemológico, sem prejuízo de outras fontes, opta-se por percorrer como fio condutor os princípios da CE propostos por Koskela (1992).

Os resultados, em princípio, seriam validados por Estudo de caso direto. Como tal investigação dedutiva empírica dependeria de trabalhos de campo, obstado pelas limitações sanitárias decorrentes da pandemia, optou-se pela investigação da hipótese por meio de estudo de fonte bibliográficas inferindo-se dados de outras pesquisas.

\section{REVISÃO BIBLIOGRÁFICA}

\subsection{PRODUÇÃO ENXUTA}

Muito se fala sobre produção enxuta e suas diversas ferramentas e funcionalidades nas indústrias atuais. Sua chegada deu-se nos anos 50 logo após a segunda guerra mundial por meio dos engenheiros japoneses Eiji Toyoda e Taiichi Ohno, que visitaram a fábrica de FORD e observaram que sua alta produção não correspondia ao mercado de seu país, adaptando então para a realidade de suas indústrias e clientes. Assim surgiu o sistema de Iean Manufacturing, sendo a Toyota pioneira neste método.

Sua estratégia consiste em uma produção puxada que busca melhorias continuas em toda produção. A visão da montadora Toyota era uma produção baseada em uma nova dimensão de administração de negócio como manufatura, desenvolvimentos de produtos, e um melhor relacionamento com os clientes. Segundo Dennis (2008) representa fazer mais com menos, isso inclui menos tempo, espaço, esforço humano, maquinas e material.

Focando na eliminação de desperdícios a Toyota produzia apenas o essencial solicitado pelos clientes, assim evitando desperdícios. Produzir apenas o necessário, e na quantidade requerida, afim de reduzir custos (OHNO, 1997).

Baseado nesse princípio foram descobertos sete tipos de desperdícios :a) Desperdício de Espera; b) Deperdício de Defeito; c) Desperdício de Transporte; d) Desperdício de Movimentação; e) Desperdício de Estoque; f) Desperdício de Superprodução; g) Desperdício de Processamento.

Para que se alcance altos níveis de qualidade e redução de desperdício deve é necessadio segundo (TAYLOR, 1992):

Vemos e sentimos o desperdício das coisas materiais. Entretanto as ações desastradas, ineficientes e mal orientadas dos homens não deixam indícios visíveis e palpáveis. E por isso, ainda que o prejuízo diário resultante seja maior que o desastre das perdas de materiais, este último abala profundamente, enquanto aqueles apenas levemente nos impressionam (TAYLOR, 1992).

E deste modo foi baseada a casa Toyota, enfatizando a eliminação de todos os desperdícios, tendo seus dois pilares de base o Just in Time e o Jidoka (automação), todos estando adequadamente estabilizados. 


\subsection{CONSTRUÇ̃̃O CIVIL}

O ano de 2020 provavelmente ficará marcado na história pelos devastadores efeitos da Pandemia do Covid-19. Para além do angustiante número de mortos que a pandemia impõe ao mundo, ultrapassando mais de 247.000 (duzentos e quarenta e sete mil) mortos, segundo o relatório da OCDA, "Política tributária e fiscal em resposta à crise do Corona Vírus: fortalecendo a confiança e a resiliência", o mundo deve amargar uma recessão de ao menos $3 \%$, podendo chegar até $6 \%$ em países subdesenvolvidos como o Brasil. Neste contexto é inevitável que as preocupações repousem na crise econômica e na busca de caminhos para superá-la.

No segmento da Construção Civil não é diferente. Crise, aliás, não representa efetiva novidade ao setor. Após cinco anos de retração, que levaram o segmento a encolher 20,5\% de 2014 a 2018, e de um tímido crescimento de 1,2\% em 20191, apresenta-se fortemente impactada pelas consequências econômicas da pandemia que impõe o isolamento social e paralização a maioria dos países do mundo.

Por outro lado, a relevância do setor da construção civil para a economia brasileira é incontestável uma vez que a mesma encontra-se entre os setores que mais emprega mão de obra formal, sendo as empresas responsáveis por arrecadar cerca de 5,8\% do PIB, aproximadamente R 255,2 bilhões (IBGE, 2012).

\subsection{CONSTRUÇÃO ENXUTA}

0 presente estudo tem por objeto a investigação do que vem a ser o modelo de Construção Enxuta, quais seus pressupostos e de quais as possíveis vantagens que o modelo poderia representar em momentos de crise. A hipótese que se pretende demostrar é de que a adoção dos pressupostos da Construção enxuta representa importante instrumento para superação da crise que se apresentará no setor após as consequências econômicas da atual pandemia do Covid - 19.

Busca-se investigar se a construção enxuta, pautada na incorporação das premissas do Sistema Toyota de Produção à construção civil, possibilitaria ganho de eficiência não apenas no contexto econômico, mas ainda no setor da saúde do trabalhador e dos custos sociais, tendo em vista a viabilidade da redução de acidentes de trabalhos e, assim, de gastos previdenciários como o afastamento doença e auxílio doença/acidente dos trabalhadores.

Neste contexto, o estudo percorrerá uma revisão documental-bibliográfica de fontes e doutrinas nacionais e internacionais, por meio da pesquisa qualitativa de doutrinas. Como corte epistemológico, sem prejuízo de outras fontes, opta-se por percorrer como fio condutor os princípios da CE propostos por Koskela (1992).

O modelo tradicional da construção civil é um modelo de conversão (figura 01). Neste modelo, a atividade produtiva consiste em um somatório de atividades de conversão que transforma os insumos em produtos intermediários. A soma destas conversões resultaria no produto final: a edificação. (KOSKELA, 1992).

0 modelo tradicional de processos de conversão foi desenvolvido no século XIX por meio de processos produtivos únicos e simples. Nada obstante, as transformações pelo qual o mesmo se submeteu no curso do século XX colocaram em xeque tal modelo, tendo em vista a crescente complexidade do processo produtivo. $\mathrm{O}$ planejamento focado apenas na transformação passa a ser insuficiente para melhor otimização do processo produtivo. (RUPPENTHAL et al., 2015).

1 Conforme reportagem publicada em 03 de abril de 2019 na revista exame, acessada no sítio eletrônico https://exame.abril.com.br/pme/como-a-construcao-civil-se-reinventou-para-vencer-a-crise/, em 29 de abril de 2020. 
Figura 01: Processo tradicional

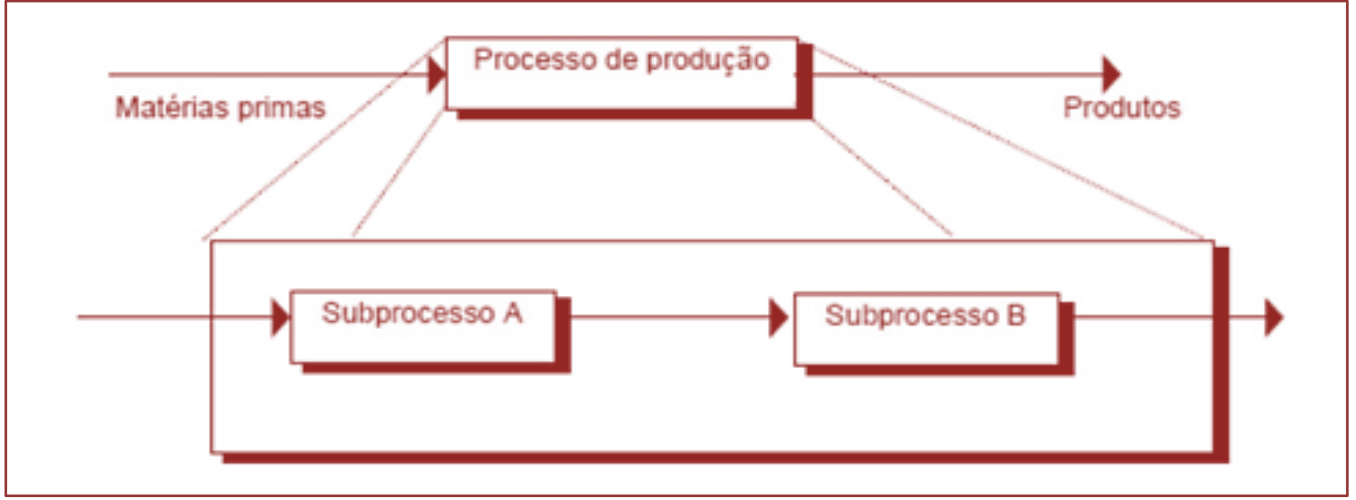

Fonte: Adaptado de Koskella (1992)

A partir da década de 80 surge a tendência de incorporação das ferramentas do modelo de produção Toyota, pautado pela gestão de qualidade total à construção civil. Busca-se a melhoria do processo produtivo focando na redução de resíduos, aumento de valor para os clientes, buscando ainda a melhoria contínua.

O percussor da nova filosofia de produção na construção civil foi Koskela (1992), seguido por expressivas contribuições feitas pelo International Group for Lean Construction (IGLC) para a concepção de um embasamento teórico da construção enxuta por meio da abstração 47 de conceitos chaves da lean production e de sua aplicação a processos de gerenciamento de construção (SALEM et al, 2005).

Figura 02: Processo enxuto

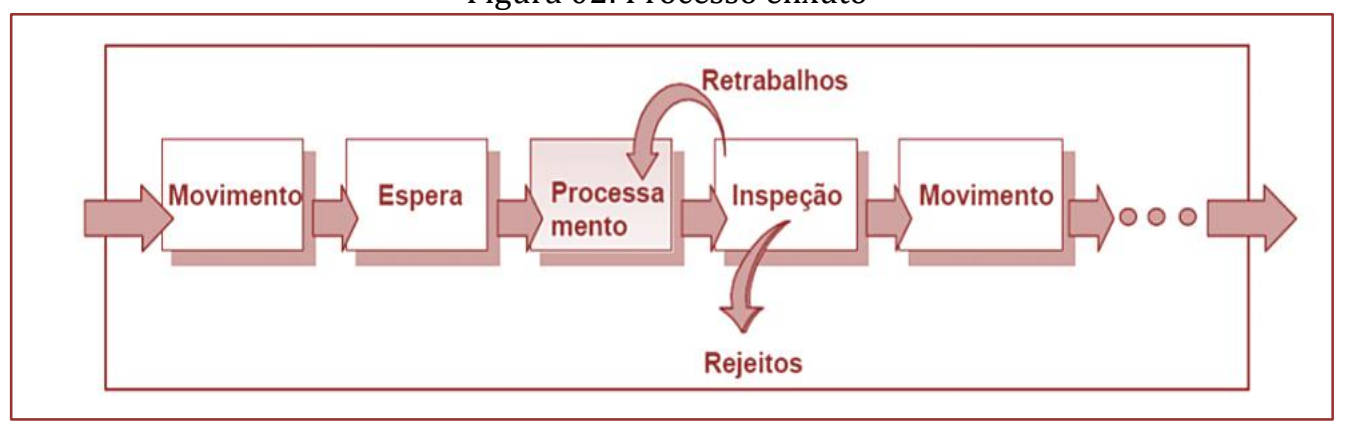

Fonte: adaptado de Koskella, (1992)

No novo modelo proposto, como observamos da figura 2 há uma representação de um exemplo proposto da construção enxuta, desde a matéria prima ao produto final. Neste fluxo o material é processado, inspecionado, estocado ou movimentado. Os processos de fluxo caracterizam-se por custo, tempo e valor sendo o último fator dependente da satisfação do consumidor. As atividades de fluxo adequam-se a produção minimizando ou eliminando desvios nos planos de produção. (KOSKELLA, 1992)

A Lean Construcion promove conceitos a partir dos tradicionais para melhoras constantes, como expõe o quadro: 
Tabela 01: Comparação entre o modelo tradicional e enxuto.

\begin{tabular}{|c|c|c|}
\hline & Modelo tradicional & Modelo enxuto \\
\hline Conceitos de produção & $\begin{array}{llll}\checkmark & \text { Produção } & \text { consistem } & \text { em } \\
\text { conversão. } & & \\
\checkmark & \text { Todos as } & \text { atividades } & \text { que } \\
\text { constituem o processo agregam valor. }\end{array}$ & $\begin{array}{l}\checkmark \\
\text { conversão e fluxodução é composta em } \\
\text { con } \\
\checkmark \quad \text { Nem todos os fluxos agregam } \\
\text { valor. }\end{array}$ \\
\hline Foco de controle & Custo das atividades. & $\checkmark \quad$ Custo tempo e valor dos fluxos. \\
\hline Foco de melhorias & $\begin{array}{l}\checkmark \quad \text { Aumento de rendimento pela } \\
\text { introdução de novas tecnologias. }\end{array}$ & $\begin{array}{l}\checkmark \\
\text { que não agregam valor; } \\
\checkmark \quad \text { Aumento de rendimento em } \\
\checkmark \quad \text { ato de atividades } \\
\text { atividades que adicionam valor, através } \\
\text { de melhoria constante e novas } \\
\text { tecnologias. }\end{array}$ \\
\hline
\end{tabular}

Fonte: Adaptado, Koskela (1992)

Para Koskella (1992) a qualidade da produção aumenta quando adotamos três recomendações: I. Pouca variabilidade nos processos seja preterindo ou projetando os mesmos; II. Detectar e corrigir falhas de maneira rápida e eficiente; III. Definir orientações para toda atividade de transformação. Outro fator que caracteriza os processos é a geração de valor. Sobre o ponto de vista enxuto caracteriza:

Não limitando-se apenas a execução de obras, mas se encaixa na gestão das mesmas, tendo como base as teorias que foram aplicadas na produção, assim tendo respostas as melhoras continuar. Sua aplicação começa na elaboração dos projetos, planejamentos, controles afim de evitar desperdícios, portando melhorando os fluxos e os tornando contínuos nas obras. (Isatto et al. 2000, p. 9).

O modelo tradicional não é totalmente errado, pois é aplicável em sistemas simples que tenha sua produção centralizada em apenas um processo de produção. Isatto et al. (2000) salienta que a complexidade dos fluxos nos sistemas de produção decorre a partir do aumento de processos em mercados mais competitivos, onde o modelo tradicional de conversão não supre as mesmas necessidades por diversas atividades que requerem atenção. Como reflexo de um aumento no mercado mais competitivo, vem a exigência de clientes com um maior foco nos mesmos para gestão dos processos.

As empresas de construção civil com seus setores de peculiaridades, ao utilizarem medidas precisam analisar seus processos para moldar de maneira pertinente as medidas de construção enxuta com o objetivo de possuir êxito em seus sistemas de fluxo.

\subsubsection{PRINCÍPIOS DA CONSTRUÇÃO ENXUTA}

Koskella (1992) enfatizou onze princípios afim de maximizar a eficiência e eficácia nas atividades de conversão e minimizar e/ou eliminar fluxos que não agregam valor. Por meio dos princípios é embasado o método e aplicação assim direcionando para tornar os devidos fins viáveis:

1. Reduzir a participação de atividades que não agregam valor;

2. Aumentar o valor do produto através da consideração das necessidades dos clientes;

3. Reduzir a variabilidade;

4. Reduzir tempo de ciclo;

5. Simplificar através da redução do número de passos ou partes;

6. Aumentar a flexibilidade de saída;

7. Aumentar a transparência do processo;

8. Focar o controle no processo global;

9. Introduzir melhoria contínua no processo;

10. Manter um equilíbrio entre melhorias nos fluxos e nas conversões;

11. Fazer benchmarking. 


\subsection{TÉCNICAS PARA A PRÁTICA DA CONSTRUÇÃO ENXUTA}

São diversos os mecanismos e as ferramentas incorporadas na construção enxuta, vindo desde a casa Toyota com seus princípios incorporados. Há também outras ferramentas e ideias a serem aplicadas adequando as necessidades de cada empresa, incorporando-as nos momentos certos e nos devidos problemas. Algumas das técnicas são:

\section{a) Last Planner}

Técnica que designa um indivíduo ou um grupo pessoas para ser responsável por uma unidade de controle de produção, ou seja, é o alcance de metas pessoais a nível operacional. Sua aplicação deve ser por meio de fluxo de trabalho, mapeando o fluxo dos suprimentos, em todas as unidades e fluxos de produção. Portanto pode ser feito através de cronogramas de previsão, que determinam a evolução e atribuem a quantidade de trabalho para cada setor (AZIZ; HAFEZ, 2013).

o Cronograma principal é dividido em vários pacotes, especificando as técnicas de aptidão, execução, além do estoque de espera. 0 escopo do cronograma deste programa é de duas a seis semanas organizado por equipes de trabalho (AZIZ; HAFEZ, 2013).

\section{b) Engenharia Simultânea}

A Engenharia Simultânea (Concurrent Engineering) pode ser descrita como a execução de tarefas sincrônicas por equipes multidisciplinares. Objetiva produtos funcionais, com a alta qualidade e produtividade. Para alcançar o propósito, utilizam-se ferramentas de análise de rede e cronogramas para ajustar as tarefas paralelas (AZIZ; HAFEZ, 2013).

Para o autor, o planejamento é fundamental para as atividades simultâneas, é avaliado o tempo necessário da atividade (lead time), quais os riscos e incertezas. Seu enfoque é nos esforços em equipe para que tenham êxito em resultados novos por meio de comunicação e compartilhamento de informaç̧ões. Para que seja bem sucedida a produção enxuta, é necessário o envolvimento de todos na obra, desde o estágio inicial.

\section{c) Reuniões diárias}

As reuniões diárias disponibilizam uma plataforma para que todas as equipes possam compartilhar opiniões, as conclusões de atividades podendo ser as de forma paralela, as dificuldades que enfrentam durante o processo de produção (AZIZ; HAFEZ, 2013).

\section{d) Kanban}

o Kanban tem como base o Sistema Just in time utilizando sistemas como o controle de estoque, fornecedores, veículo de coleta, almoxarifado e sistema de gerenciamento de inventário (AZIZ; HAFEZ, 2013).

Há diversos modelos de sistemas Kanban. 0 original consiste em dois sinais (o sistema de Kanban cartão dual): Autorização para a produção em quantidade certa (sinal de produção) é a autorização onde o produto pode ser transportado dando sequência ao processo (sinal de transporte). Mais uma característica deste processo é a produção puxada, baseada no inventário ou na programação prevista nas estações de trabalho. 0 controle de fluxo e descentralizado e feitos por empregados de todos os setores do processo produtivo (FILHO; JUNIOR, 2010).

Ainda segundo o autor, pode haver variações na aplicação do Kanban, pois cada empresa utilizará conforme sua necessidade, e as diferenças podem ocorrer como os níveis de inventário, ou na mudança dos significados dos sinais, alterando o uso dos cartões para outro tipo de sinal.

\section{e) PCMAT (Plan Conditions and Work Envionment in the Consruction Industry)}

O PCMAT é a introdução de um plano de saúde e segurança na execução de projetos na indústria da construção. São partes das atribuições das empresas com a segurança, uma vez que podem limitar 
atividades já programadas. Todas as atividades relacionadas à segurança são, portanto reunidas no planejamento em curto prazo através de feedbacks diários (AZIZ; HAFEZ, 2013).

\section{f) Ferramentas de gerenciamento de qualidade}

A inclusão de ferramentas de gerenciamento de qualidade no processo visa qualificar a execução das entregas planejadas - em tempo, custo e qualidade -, auxiliando os colaboradores a seguirem os processos planejados ou efetuarem soluções necessárias de qualidade (AZIZ; HAFEZ, 2013).

\section{g) Identificação visual}

A identificação visual é mais uma ferramenta que contribui na redução de erros e desperdícios. Por meio de um olhar geral na produção, minimiza a produção desigual sendo eficaz na aplicação de ferramentas visuais facilitando a identificação e contribuindo com a rapidez dos processos produtivos repetitivos e na diminuição de riscos na seleção de produtos (AZIZ; HAFEZ, 2013).

Para o escritor, a utilização de gráficos e cronogramas de progresso podem completar a aplicação e êxito na conclusão das atividades, em etapas de projeto e supervisão. Outra ferramenta de auxilio é a aplicação de tecnologias.

\subsection{BIM (BUILDING INFORMATION MODELING)}

O BIM - Building Information Modeling de acordo com Eastman et al. (2011) é a representação inteligente de um conjunto de dados que representam um edifício. 0 Bim possibilita a integração de processos, visando a eliminação de eficiência e redundâncias (CAMPBELL, 2007).

Muitos modelos podem representar projetos, um dos métodos tradicionais é a utilização de CAD (Computer Aided Desing) onde há evasões para muitos erros devido aos projetos que não estão automatizados, podendo demandar custos adicionais no decorrer do processo e atrasos (EASTMAN el al, 2011).

Figura 03: Comparação entre os métodos Tradicional x BIM.

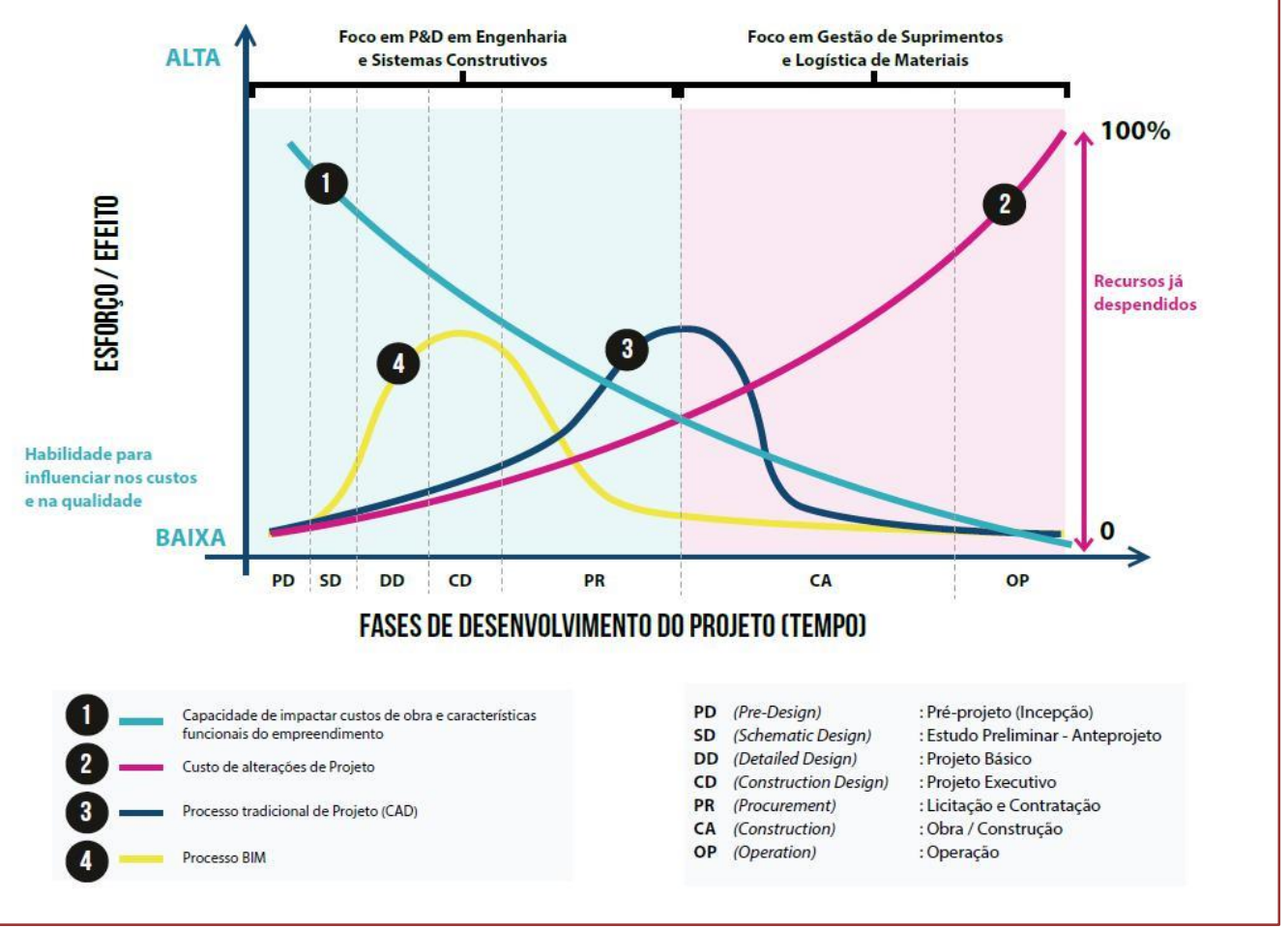

Fonte: CBIC (2016) 
De acordo com a figura, o uso do método BIM exige mais esforço e efeito nas etapas de projetos executivos e básicos, focando na concepção, pesquisa e solução, afim de reduzir custos e recursos. Já no modelo tradicional o maior esforço se encontra na parte de concentração e licitação, obra/construção. Conforme a progressão nas etapas, a capacidade de influência na qualidade e custos tendem a diminuir. Quanto mais avançada é a etapa da obra, maior será o custo de alteração.

Para que o uso do BIM seja utilizado de maneira mais eficaz, é necessário destinar as etapas e processos desde a sua concepção, sendo de suma importância adequá-lo conforme a etapa de viabilização da obra, no intuito de aumentar o potencial de melhorias nas fases de projeto, construção, operação e manutenção da edificação (CIC, 2011).

Figura 04: 0 uso do BIM conforme as etapas das obras

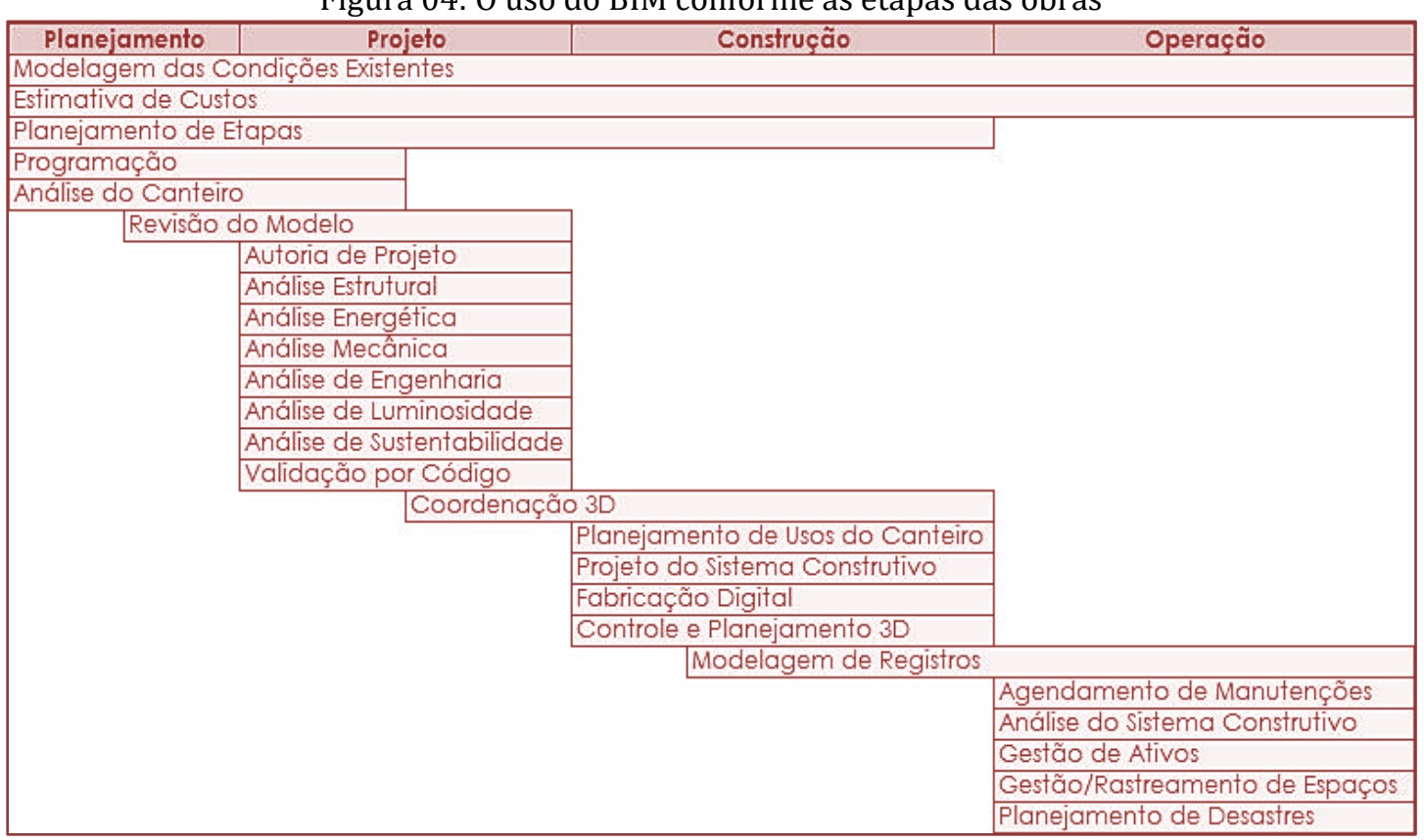

Fonte: adaptado de CIC (2011)

Seus benefícios são adequados conforme as etapas e necessidades. Segundo o volume 1 da coletânea Implementação do BIM para Construtoras e Incorporadoras (2016), seus benefícios são: colocação de regras de verificação; controle e registos visuais às mudanças condicionadas as versões dos modelos; atentar ao acesso para manutenção do local modelado (medidas e acesso do ser humano as áreas de instalações); possibilidade de embasamento de gestão de ativos. Outros benefícios são citados conforme Eastmam et al. (2011) como:

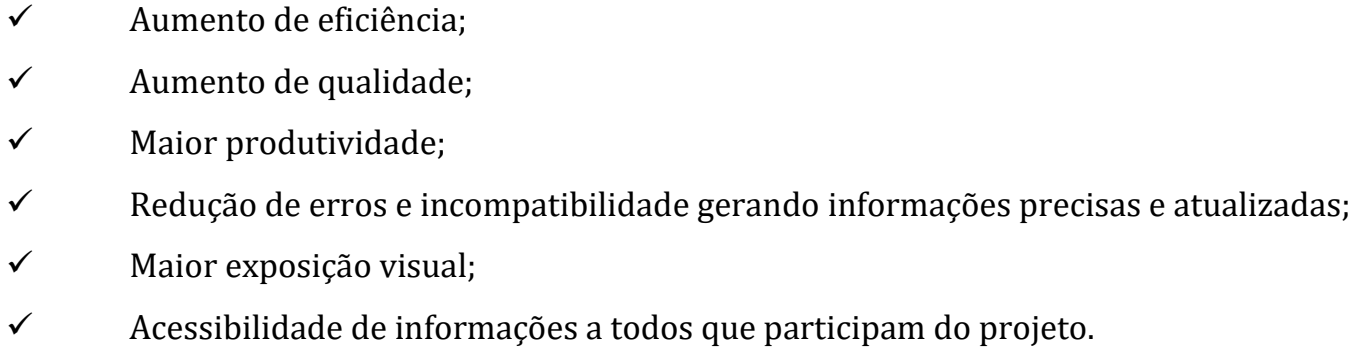

Com a integração do BIM com o Lean Construction potencializando a eficiência dos processos e redução de desperdícios, assim otimizando resultados e aumentando o valor agregado aos projetos que é utilizado a junção destas ferramentas.

\section{METODOLOGIA}

O procedimento metodológico empregue neste trabalho propõe analisar como o Lean Construction pode contribuir com o aumento da competitividade das construtoras na retomada pós-quarentena, por meio de 
diagnósticos da situação e tomada de decisões, identificando as ferramentas adequadas. Para isso, dividimos o estudo em fases representadas na Figura 05.

Figura 05: Fluxograma das fases do estudo.

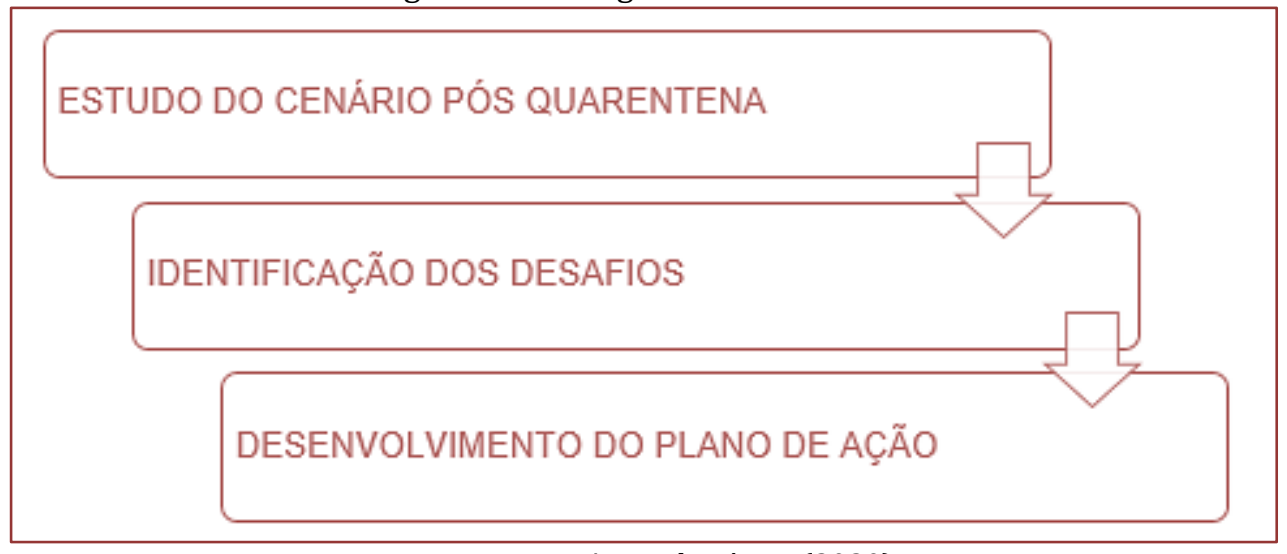

Fonte: Autoral própria (2020)

\subsection{ESTUDO DO CENÁRIO PÓS-QUARENTENA}

Buscando entender como o setor da construção civil irá se comportar quando a economia retomar após o término da quarentena foi realizado um levantamento do possível cenário deste ramo, utilizando informações e dados de instituições ligadas ao setor que monitora as atividades da construção civil no Brasil.

As instituições usadas como fonte de informação foram: Associações Brasileiras de Arquitetos, Associações Brasileiras de Engenheiros, Associações Brasileiras de Empresas da Construção Civil, Associações Bras. de Empresas e Profissionais de Consultoria e Projetos de Construção, Associações Brasileiras de Fabricantes e Fornecedores de Materiais de Construção, Associações Brasileiras de Revendedores de Materiais de Construção, CBIC - Câmara Brasileira da Indústria da Construção Civil, Confederações Ligadas a Construção Civil, CONFEA - Conselho Federal de Engenharia Arquitetura e Agronomia, Conselhos Regionais de Engenharia Arquitetura e Agronomia, Entidades Ligadas a Pesquisa e Aperfeiçoamento Tecnológico de Materiais Usados na Construção Civil, FNA - Federação Nacional dos Arquitetos Urbanistas, FNE - Federação Nacional dos Engenheiros, Entidades Ligadas ao Mercado Imobiliário, Órgãos Públicos Federais Ligados a Construção Civil, Programas Brasileiros de Fomento da Construção e Sindicatos Ligados a Construção Civil.

Todas as informações e dados foram agrupados por ordem de frequência de ocorrência nos levantamentos das instituições consultadas. A ordenação das informações e dados nos permitiu identificar os maiores desafios que poderão ocorrer na retomada pós-quarentena.

\subsection{IDENTIFICAÇÃO DOS DESAFIOS}

Nesta fase, o estudo concentrou-se em estabelecer os maiores desafios a serem enfrentados pelo campo da construção civil na retomada pós-quarentena. Para isso as informações e dados compilados na fase anterior foram usados na construção de um Diagrama de Pareto.

O Diagrama de Pareto é um gráfico montado a partir do princípio que ocorre na maioria das situações, usando a proporção de $80 \%$ das consequências dos resultados para $20 \%$ das causas. Com base nisso, é montado um gráfico de barras onde se determina os problemas prioritários a partir da frequência, correspondendo do maior para o menor e consequentemente dos mais graves aos mais leves tornando a visualização e identificação das perdas mais fácil. O Diagrama de Pareto ajudou a estabelecer um foco na resolução dos maiores desafios. 


\subsection{DESENVOLVIMENTO DO PLANO DE AÇÃO}

Considerando os desafios identificados no Diagrama de Pareto, foi desenvolvido um plano de ação para a resolução de problemas que as empresas de construção civil estarão enfrentando após a retomada das atividades. 0 plano de ação visa atender aos princípios do lean cronstruction.

Para este fim foram identificados tanto os instrumentos mais adequados para resolução dos problemas como também os possíveis resultados esperados com a aplicação das ferramentas sugeridas. 0 Plano de Ação ainda estabeleceu os pré-requisitos necessários para a aplicação dos princípios lean e das ferramentas.

\section{RESULTADOS}

A temática apresentada neste capítulo disserta acerca dos resultados obtidos através dos levantamentos realizados, no qual os mesmos serão descritos de acordo com os passos citados na metodologia afim de atingir as metas propostas, sendo elas: características dos maiores desafios a serem superados pela construção civil no pós-pandemia; classificação utilizando o Diagrama de Pareto e as devidas tomadas de decisão, e a identificação das ferramentas do Lean Construction que podem ser utilizadas na resolução de problemas oriundos dos desafios, analisando os resultados esperados.

\subsection{LEVANTAMENTO DO POSSÍVEL CENÁRIO DO SETOR DA CONSTRUÇÃO CIVIL PÓS-QUARENTENA}

Nesta etapa houve um levantamento mediante diversas entidades de pesquisa, onde foram encontradas as maiores dificuldades que o atual cenário está provocando. Os resultados são apresentados na Tabela 02.

Tabela 02: Entidades e seus problemas.

\begin{tabular}{|c|c|c|}
\hline ITEM & Fonte & Produção da Mão de Obra \\
\hline 1 & IBGE & Redução da Mão de Obra \\
\hline 2 & SIDUSCON & Redução de demanda \\
\hline 3 & CBIC & Atraso no Fornecimento \\
\hline 4 & FGV & Paradas intermitentes \\
\hline 5 & & Redução de demanda \\
\hline 6 & & Redução de demanda \\
\hline 7 & SEBRAE & Redução de demanda \\
\hline 8 & Agência Brasil & Redução de demanda \\
\hline 9 & ASBEA & Redução de produção \\
\hline 10 & ABCEM & Redução de demanda \\
\hline 11 & ABECE & Redução de produção \\
\hline 12 & VALE & Redução de produção \\
\hline 13 & ABCIC & Readaptação do processo construtivo. \\
\hline 14 & ABDIB & Redução de demanda \\
\hline 15 & Banco central & Redução de demanda \\
\hline 16 & ABEMI & Redução de demanda \\
\hline 17 & ANAMACO & Redução de demanda \\
\hline 18 & ANICER &
\end{tabular}

Fonte: Autoria própria (2020)

\section{Os desafios encontrados foram:}

a) Redução de mão de obra: No momento presente, houve a necessidade de adaptar o canteiro de obras para o novo normal com as medidas de segurança indicadas pela Organização Mundial de Saúde (OMS), por exemplo, evitar equipes numerosas a frente de trabalho para esquivar-se da disseminação do vírus, afastar funcionários que apresentam sintomas e posicionar funcionários dependendo da sua ocupação em Home Office. Outro fator que pode ocorrer é o das demissões, além das novas readequações do canteiro e da quantidade de operários.

b) Redução de Demanda: Um dos maiores reflexos do pós Covid-19 será a retração do mercado, de acordo com o levantamento de Indicadores imobiliários Nacionais do 1o Trimestre feito pelo CBIC 2020 que detalha os índices de desistência de compras. Dentre os motivos está a incerteza sobre a duração da pandemia $46 \%$, incertezas sobre emprego e renda $24 \%$, perda de renda $20 \%$, mudança de objetivos 
pessoais $12 \%$, objetivos de economia pessoal $9 \%$ e perda de emprego $8 \%$. A crise afetou a intenção de compra e dificultou o modelo de busca para aquisição de imóveis, afetando diretamente a demanda.

c) Atraso de Fornecimento: Um dos grandes impactos causados pelo Covid-19 é a cadeia de suprimentos. Por conta das medidas adotas como o fechamento de fábricas, comércios e outros segmentos incluindo o isolamento de países e cidades, a logística no fornecimento foi afetada causando prejuízos na indústria da construção civil.

d) Paradas Intermitentes: Por conta das novas medidas adotadas em canteiros de obras para o cumprimento das medidas de segurança na saúde, houve a necessidade de novas providências. Algumas obras tiveram a adoção de distanciamento e com isso houve medidas como flexibilização em relação a número de operários. As medidas de distanciamento foram aplicadas não apenas em relação a distância de $2 \mathrm{~m}$ em relação aos funcionários do canteiro, mas com Home Office e as férias coletivas priorizando os funcionários com mais de 60 anos.

e) Redução de Produção: Por conta da pandemia e adequação nos métodos de produção, seja no layout, ou na aplicação das medidas de segurança, houve diversos fatores que acarretaram uma queda nos ramos. Segundo a Confederação Nacional da Indústria (CNI) houve redução ou paralização em cerca de $76 \%$ da indústria, e por consequência, houve queda no faturamento, dificuldade no cumprimento de pagamentos correntes, descumprimento com clientes, cancelamento de pedidos, restrições no acesso a crédito e falta de insumos.

f) Readaptação do processo produtivo: Por conta de novas exigências da Organização Mundial de Saúde (OMS), houve readequação tanto na inclusão de novos hábitos, quanto no layout, para respeitar as medidas de distanciamento, adequando o ambiente.

Representatividade dos problemas:

Gráfico 01: Representação dos problemas.

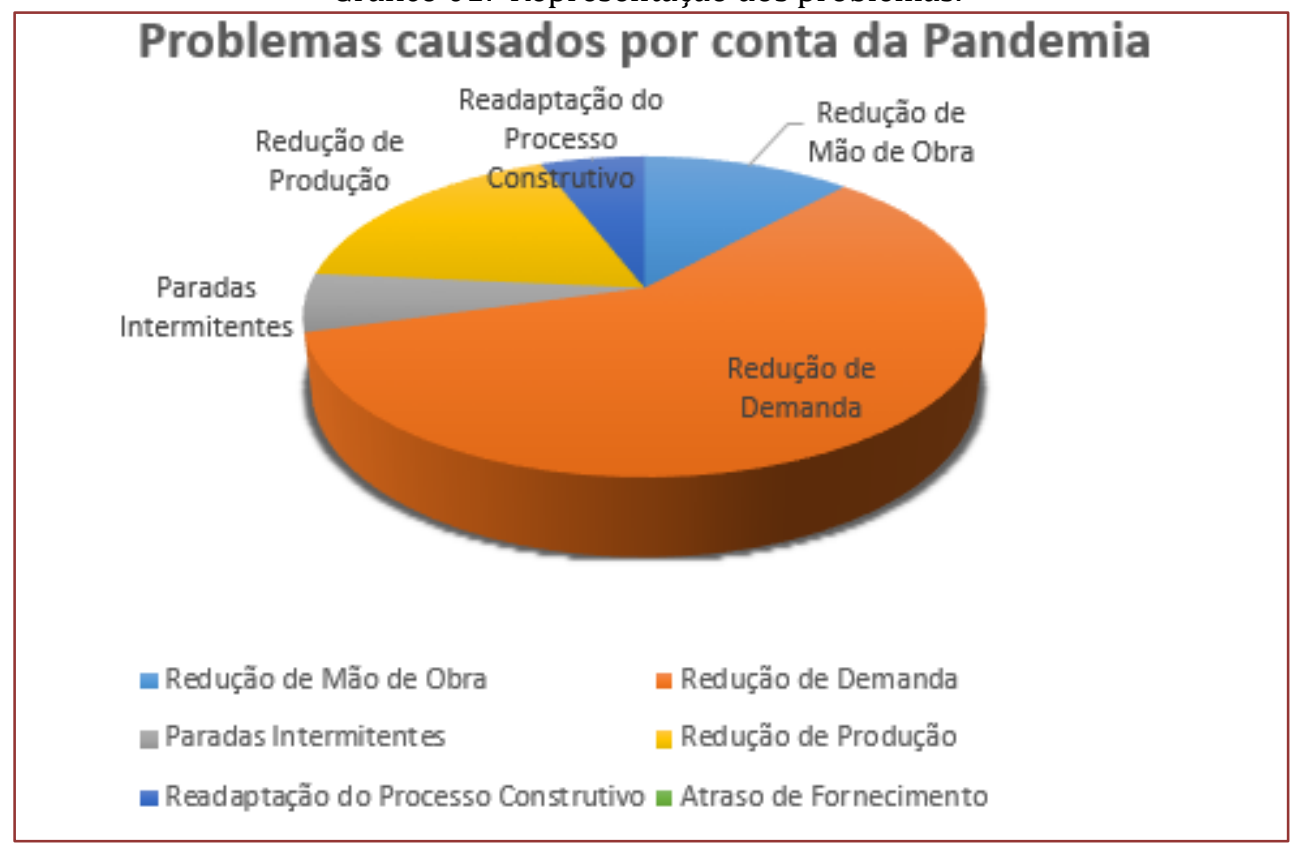

Fonte: Autoria própria, (2020)

\subsection{CLASSIFICAÇÃO DOS MAIORES DESAFIOS A SEREM SUPERADOS PELO DIAGRAMA DE PARETO}

Ao utilizar o Diagrama de Pareto, torna-se possível a identificação dos problemas prioritários, de fatores importantes, o enfoque no eixo dos nossos esforços e na utilização dos mesmos. Foi elaborado o levantamento de dados identificando os defeitos, e suas quantidades, quantificando em forma de porcentagem (Tabela 03). 
Tabela 03: Levantamento para elaboração do Diagrama de Pareto

\begin{tabular}{|c|c|c|c|}
\hline \multirow{2}{*}{ Tipos de Defeitos } & \multicolumn{2}{c|}{$\begin{array}{c}\text { Quantidade de } \\
\text { problemas identificados }\end{array}$} & \multicolumn{2}{c|}{ \%Ocorrência } & \multicolumn{2}{c|}{$\%$ Acumulado } \\
\hline Redução de demanda & 10 & $55,56 \%$ & $55,56 \%$ \\
\hline Redução de Produção & 3 & $16,67 \%$ & $72,22 \%$ \\
\hline Redução de Mão de Obra & 2 & $11,11 \%$ & $83,33 \%$ \\
\hline Atraso de Fornecimento & 1 & $5,56 \%$ & $88,89 \%$ \\
\hline Paradas Intermitentes & 1 & $5,56 \%$ & $94,44 \%$ \\
\hline Readaptação do Processo Construtivo & 1 & $5,56 \%$ & $100,00 \%$ \\
\hline
\end{tabular}

Fonte: Autoria própria, (2020)

A partir dos dados obtidos com o resultando do levantamento, sua frequência de ocorrência e seu acumulo, foi elaborado o diagrama de Pareto representado no Gráfico 02.

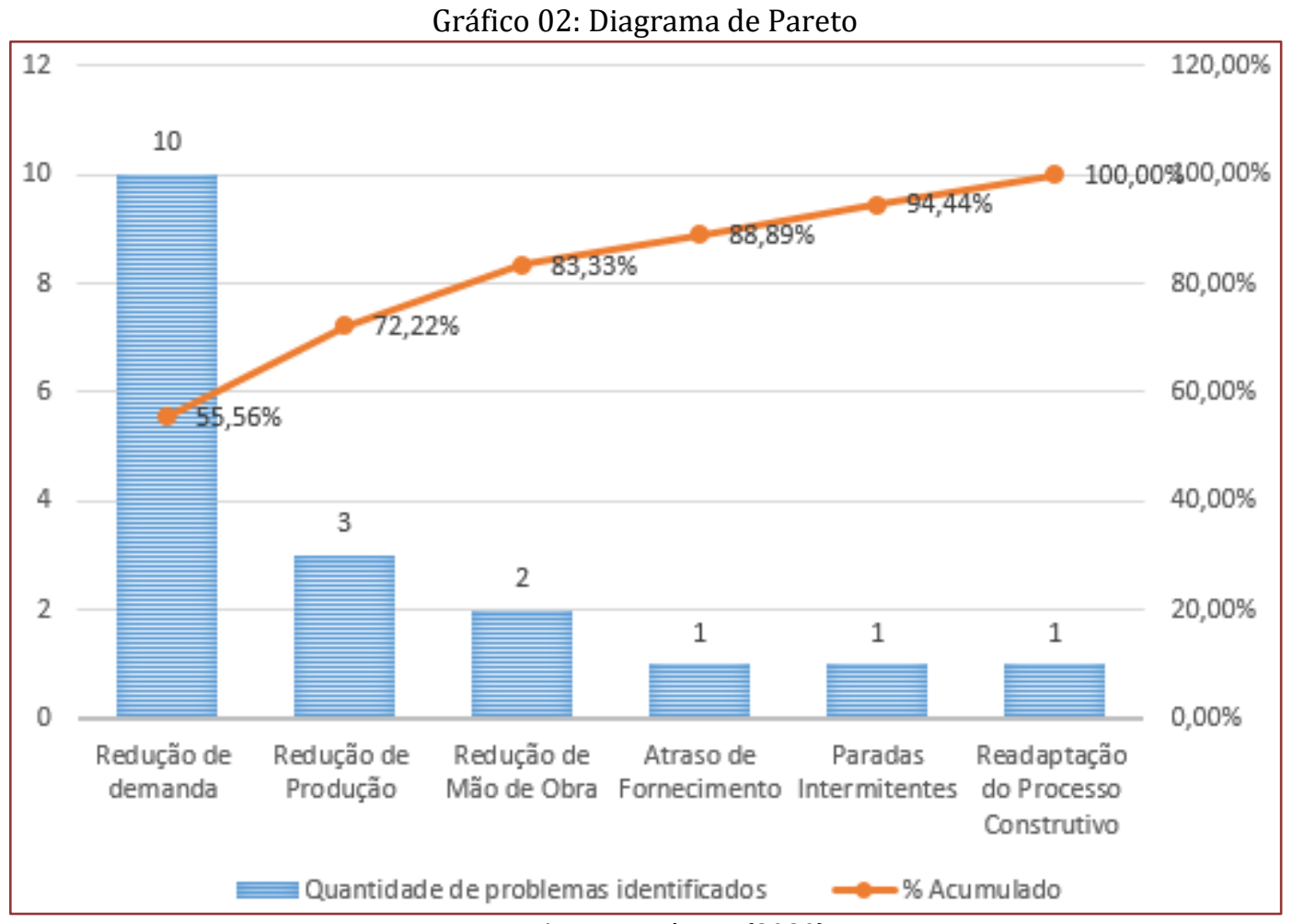

Fonte Autoria própria, (2020)

De acordo com o Diagrama de Pareto que relaciona $80 \%$ dos problemas relatados à $20 \%$ de soluções, a Figura 15 demonstra que problemas como a Redução de demanda, Redução de Produção e Redução de Mão de Obra, correspondem a mais de $80 \%$ das complicações relatadas. Isso significa que as empresas devem concentrar seus esforços na resolução dos problemas. A seguir serão apresentadas as possíveis ações a serem tomadas baseadas nos princípios fundamentais do Lean Construction.

\subsection{FERRAMENTAS DO LEAN CONSTRUCTION PARA RESOLUÇÃO DE PROBLEMAS}

\subsubsection{REDUÇÃO DE DEMANDA}

Buscando adequação à demanda do mercado, os princípios do Lean que precisam ser atendido são: Aumento da Flexibilidade de Saída, Redução do Tempo de Ciclo e Realização do Benchmarking. Para aumentar a flexibilidade de saída, a empresa readaptaria o processo produtivo. Essa readaptação teria que atender as novas necessidades do seu público alvo. Uma das necessidades relatadas pelo estudo do CBIC de Indicadores Imobiliários Nacionais - 1ํo Trimestre de 2020 está relacionada a redução ou até mesmo a perda da renda. Portanto ajustar o processo produtivo para redução do custo final seria uma forma de repassar essa redução para o preço final do produto. Outra necessidade a ser atendida seria a sua preferência pelo sistema construtivo. No sistema construtivo convencional a redução do custo seria por meio da redução de perdas. Os maiores danos desse sistema produtivo são movimentação, transporte, 
espera e estoque. Para identificação e quantificação desses prejuízos, seria necessário realizar o mapeamento de fluxo, usando a metodologia Mapeamento da Cadeia de Valor (VSM).

Ainda para o sistema convencional, seria necessário reduzir o tempo de ciclo aprimorando o processo, podendo incluir o uso de tecnologias. Nesse estágio torna-se indispensável o uso da tecnologia BIM. Seria indicado para otimização do processo construtivo, simulações do método construtivo e do impacto de custo. Para essas simulações são necessárias ferramentas de BIM nas dimensões 3D, 4D e 5D.

Caso o público alvo não apresente restrições quanto ao uso de outros sistemas, seria possível optar por tecnologias já usadas no mercado. Atendendo ao princípio do Beanchmarking, seria indicado adotar técnicas construtivas que já apresentam tempo de ciclo reduzido e processo enxuto. Entre esses sistemas construtivos podemos citar alvenaria estrutural, parede de concreto e Steel Frame. Esses sistemas construtivos sedimentados no mercado com equipamentos e mão de obra já estão disponíveis, inclusive os mesmos apresentam tempo de ciclo reduzido. No entanto as empresas que não realizam a prática desses sistemas, necessitam de investimento e treinamento.

\subsubsection{REDUÇÃO DE PRODUÇÃO}

Reduzir as perdas é a primeira ação a ser tomada às empresas que tiveram redução de produção por não conseguir arcar com seus próprios custos. Além do mapeamento de fluxo do processo que permite a identificação das atividades que não agregam valor, é necessário detectar o takt time da produção. Takt é uma palavra alemã que significa cadência, frequência, ou seja, é uma ferramenta de análise instantânea para determinar a velocidade de produção usando os conceitos de Just In Time. Ajustar o tempo de produção de acordo com a demanda do cliente permite que se produza apenas o que é solicitado, aumentando a produtividade, eliminando as paradas, criando ritmo de produção. Estabelecendo um processo de produção puxado é necessário ter um controle e gestão visual que possibilite trabalhar com estoque mínimo. 0 Kanban que significa sinal, é uma ferramenta que permite disponibilizar o material para produção no momento em que é acionado pelo cliente. Os principais objetivos do Kanban são: regular as flutuações da procura e o volume de produção dos postos de trabalho; minimizar as flutuações do estoque de fabricação até gerar estoque "zero", regular as flutuações do estoque de fabricação entre os postos de trabalho e produzir a quantidade exata no momento em que é solicitado. Com essas ferramentas será possível reduzir a variabilidade no processo, reduzir perdas e custos com atividades que não agregam valor.

\subsubsection{REDUÇÃO DE MÃO DE OBRA}

Ao mapear o fluxo de produção, eliminar as perdas e ajustar a produção de acordo com a demanda, tornamos o processo mais claro e transparente. Nesse estágio é possível identificar subatividades que podem ser agrupadas em células de produção. As células de produção são a organização de processos em um arranjo de pessoas, máquinas e métodos. Funcionam de forma sequencial permitindo fluxo contínuo. Esta ferramenta promove reduções significativas de estoque, tempo de produção e mão de obra. 0 conceito de célula de produção consiste em agrupar materiais e equipamentos em uma linha de fluxo, estabelecer um tempo de transferência afim de reduzir estoques intermediários e um layout que reduza o tempo de movimentação e transporte tornando a informação entre as células mais acessíveis. Porém na construção civil esse conceito exige alterações no processo de produção. Um exemplo é a criação de Kits que podem ser produzidos em células de produção com o número reduzido de pessoas atendendo a demanda da etapa posterior. No entanto, é necessário o levantamento de três informações: índice de produtividade, quantitativos e fator de dificuldade. As equipes são dimensionadas conforme essas informações que permitem formar lotes de produção.

\subsection{CONSIDERAÇÕES FINAIS}

No cenário de pandemia, além dessas ações relacionadas para a resolução dos problemas com a redução de demanda, produção e mão de obra, as paralizações das atividades serão também motivo de preocupação. Serão determinações de paralização das atividades que não dependem das atividades do setor. Porém com a redução das perdas, redução do tempo de ciclo e de variabilidade no processo é possível torna-lo previsível e controlável. Nesse contexto o Last Planner System é uma das ferramentas de planejamento de produção para criar fluxos de trabalhos previsíveis permitindo ações de remoção de restrições com até 6 ou 8 semanas de antecedência. Assim sempre que houver uma paralização será 
possível reprogramar as atividades ajustando o ritmo do processo tanto na redução de demanda quanto na redução de mão de obra. 0 Lean Construction dessa forma se apresenta como uma solução para aumentar o controle da produção e ainda permitir ações de melhoria contínua que podem ajudar na sobrevivência das empresas durante a pandemia.

\section{CONCLUSÃO}

Diante dos resultados atingidos, podemos realizar uma análise do uso do Lean Construction na construção civil. Com a chegada do Covid - 19 acarretando uma crise no setor, percebe-se que o uso desse processo é uma ferramenta importantíssima, pois ao utilizá-lo é possível identificar os desperdícios e melhorias a partir dos seus princípios e ferramentas.

Foi identificado através do levantamento de diversas instituições, os maiores problemas por conta da pandemia como a Redução de Demanda, Redução de Produção, Redução de Mão de Obra, Paradas Intermitentes e readaptação do processo construtivo, caracterizando-os. Ao avaliar os seguimentos, podemos comprovar a sua frequência e indicar os elementos e metodologias adequadas conforme o Lean.

O Diagrama de Pareto foi essencial para o esclarecimento dos maiores problemas, uma vez que o mesmo indica disfunções que afetam $80 \%$ das empresas, para indicar $20 \%$ de soluções. Com ele constatamos também que a Redução de Demanda, Redução de Produção e Redução de Mão de Obra compreendem cerca de $83,33 \%$ dos problemas que afetam a construção civil por conta do novo cenário, podendo assim, relacionar os princípios e devidas ferramentas para resolverem as adversidades.

Os princípios identificados para solucionar os problemas com Redução de Demanda, foram o aumento da flexibilidade de saída; redução de tempo de ciclo e realização do Benchmarking adequando as ferramentas compatíveis com os mesmos, como o mapeamento da cadeia de valor (VSM), inclusão de novas tecnologias como BIM 3D,4D E 5D e a adoção de novos métodos construtivos que já estão disponíveis no mercado, por exemplo, a alvenaria estrutural, parede de concreto e Steel Frame. Já para problemas com Redução de Produção, é de suma importância determinar o takt time, sendo a frequência e o JIT para determinar o tempo de produção. Outro fator importante é a produção puxada para o controle de trabalho com estoque mínimo e o Kaban, afim de reduzir a variabilidade, reduzir perdas e custos com atividades que não agregam valor. Com o mapeamento de fluxo, que possui a finalidade de eliminar perdas e ajustar a produção à demanda, o processo torna-se mais transparente e é possível aplicar a ferramenta de células de produção afim de identificar as dificuldades e solucioná-las, resolvendo assim o último problema que é a redução de mão de obra.

Em vista dos argumentos apresentados neste projeto, podemos concluir que a pandemia do novo Corona Vírus trará prejuízo em todos os setores não somente da construção civil. Entretanto, um dos métodos para ajudar as empresas a driblar a crise que nos afeta atualmente é o uso do Lean Construction, focando nos principais problemas, para que as devidas ferramentas possam sejam utilizadas, trazendo por fim, bons resultados no âmbito da Construção Civil.

\section{REFERENCIAS}

[1] ABCEM, O novo consumidor pós COVID-19. Disponível em: <https://www.abcem.org.br/site/noticias/onovo-consumidor-pos-covid>. Acesso em 04 de junho de 2020.

[2] ABCIC, Na pós-pandemia, demanda por construção rápida vai crescer. Disponível em: <http://www.abcic.org.br/Noticia/Exibir/na-pos-pandemia-demanda-por-construcao-rapida-vai-crescer>. Acesso em 04 de junho de 2020.

[3] ASBEA, Dados. Disponível em: <http://www.asbea.org.br/noticias/detalhe/comunicado-asbea-crise-covid19>. Acesso em 04 de junho de 2020.

[4] AZIZ, R. F.; HAFEZ, S. M. Applying lean thinking in construction and performance improvement. Alexandre Engineerring Journal, v. 52, n. 4, p. 679-695, 2013. Disponível em <doi: 10.1016/j.aej.2013.04.008>.

[5] BEATRIZ, Construção Civil tem 17 mil demissões no primeiro trimestre de 2020 no AM, aponta IBGE. Disponivel em: <https://g1.globo.com/am/amazonas/noticia/2020/05/18/construcao-civil-tem-17-mil-demissoesno-primeiro-trimestre-de-2020-no-am-aponta-ibge.ghtml>. Acesso em: 03 de junho de 2020.

[6] BERNADES, M. M. e S. Planejamento e controle da produção para empresas de construção civil. Rio de Janeiro: LTC, 2003. 
[7] BORBA, G. Aplicação dos conceitos de produção enxuta no processo de fabricação de radiadores e condensadores automotivos. Monografia (Especialista em Engenharia de Produção), Departamento de Engenharia de Produção da Universidade Federal do Paraná, Curitiba, 2012;

[8] CÂMARA BRASILEIRA DA INDÚSTRIA DA CONSTRUÇÃo (CBIC). Colaboração e integração BIM - Parte 3: Implementação do BIM para Construtoras e Incorporadoras. Brasília: CBIC, 2016.

[9] CAMPBELL, D. A. Building Information Modeling: the Web3D application for AEC. In: INTERNATIONAL CONFERENCE ON 3D WEB TECHNOLOGY, 20., 2007, New York. Anais... New York: Web3D, 2007. p. 173-176.

[10] CASTELO, 0 impacto da Covid-19 na Construção. Disponível em: <https://blogdoibre.fgv.br/posts/oimpacto-da-covid-19-na-construcao>. Acesso em 03 de junho de 2020.

[11] CBIC/CII, Indicadores Imobiliários Nacionais - 1o TRIMESTRE 2020. Disponível em: <https://cbic.org.br/wpcontent/uploads/2020/05/Indicadores1T2020.pdf>. Acesso em 03 de junho de 2020.

[12] CIC - COMPUTER INTEGRATED CONSTRUCTION RESEARCH PROGRAM. BIM Project Execution Planning Guide. Version 2.1. Pennsylvania: The Pennsylvania State University, 2011. Disponível em acesso em: 03 jun 2020.

[13] DENNIS, P. Produção Lean Simplificada. 2ª Ed. Porto Alegre: Bookman, 2008.

[14] EASTMAN, C.; TEICHOLZ, P.; SACKS, R.; LISTON, K. BIM handbook: A guide to building information modeling for owners, managers, designers, engineer, and contractors. New Jersey, 2011.

[15] FERREIRA, Construção Enxuta: uma ferramenta para o enfretamento do cenário atual de crise econômica. João Pessoa - PB, 2016. Disponível em: <http://ct.ufpb.br/ccec/contents/documentos/tccs/2015.2/construcaoenxuta-uma-ferramenta-para-o-enfrentamento-do-cenario-atual-de-crise-economica.pdf $>$. Acesso em 04 de junho de 2020.

[16] FORMOSO, Carlos T. Lean Construction: princípios básicos e exemplos. Porto Alegre: NORIE/UFRGS, 2002.

[17] GARVIN, David A. Gerenciando a qualidade: a visão estratégica e competitiva. 1ª̄ed. Rio de Janeiro: Qualitymark, 1992.357p

[18] ISATTO, E.L.; FORMOSO, C. T.; CESARE, C.M. de; HIROTA, E. H.; ALVES, T. da C. L. Lean Constrution: diretrizes e ferramentas para o controle de perdas na construção civil. 2. ed. Porto Alegre: SEBRAE/RS, 2000, v. 5.

[19] KOPPER, Rafael. Construção enxuta: a prática do princípio da transparência nos processos construtivos em empresas da grande Porto Alegre/RS. Porto Alegre: UFRGS, 2012.

[20] KOSKELA, L. Application of the new production philosophy to construction. Stanford, EUA, CIFE, agosto 1992. Technical Report No 72.

[21] LEXICO LEAN. Glossário Ilustrado para praticantes do pensamento lean. São Paulo: Lean Institute Brasil, 2003.

[22] LEAN INSTITUTE BRASIL. Léxico Lean: glossário ilustrado para praticantes do pensamento lean. Tradução de Lean Institute Brasil. São Paulo: Lean Institute Brasil, 2003.

[23] LIKER, J.K. O Modelo Toyota: 14 princípios de gestão do maior fabricante do mundo. Porto Alegre: Bookman, 2005.

[24] LIKER, J.K: MEIER, D. O Modelo Toyota: manual de aplicação. Porto Alegre: Bookman, 2007.

[25] MARCELO BRANDÃO, Covid-19: decreto inclui construção civil entre atividades essenciais. Disponível em: <https://agenciabrasil.ebc.com.br/politica/noticia/2020-05/covid-19-decreto-inclui-construcao-civil-entreatividades-essenciais $>$. Acesso em 03 de junho de 2020.

[26] OHNO, T.(1997) Sistema Toyota de Produção - Além da Produção em Larga Escala Porto Alegre.

[27] PEREIRA, Mariana Del Carlo. "Avaliação e análise da aplicação da filosofia Lean em empresas de construção civil da região metropolitana de Belo Horizonte”. Belo Horizonte: UFMG, 2012.

[28] PETERS, T. O círculo da inovação. São Paulo: Harbra, 1998.

[29] REVISTA ANAMARCO, Construção Civil em Tempos de Corona Vírus. Disponível em: <http://www.revistaanamaco.com.br/-construcao-civil-em-tempos-de-coronavirus>. Acesso em 03 de junho de 2020.

[30] REVISTA ANAMARCO, O Impacto do Corona Vírus no Comércio Brasileiro. Disponível em: <http://www.revistaanamaco.com.br/o-impacto-do-coronavirus-no-comercio-brasileiro >. Acesso em 04 de junho de 2020 .

[31] SARCINELLI, Wanessa Tatiany. Construção enxuta através da padronização de tarefas e projetos. 2008. Monografia (Especialista em Engenharia Civil) - Escola de Engenharia da Universidade Federal de Minas Gerais, Vitória, 2008; 
[32] SEBRAE, DADOS. Disponível em: <https://paineis-lai.sebrae.com.br/single/?appid=f9c6ba40-ae97-4aee$804 \mathrm{e}-2$ eff863f4a6f\&sheet=ce0f6f6d-5f3f-45e1-a4bd-31363554586b\&opt=currsel\&select=clearall $>$. Acesso em 03 de junho de 2020.

[33] SHINGO, S. Sistemas de Produção com Estoque Zero: O Sistema Shingo para Melhorias Contínuas. Porto Alegre: Artes Médicas, 1996.

[34] TAYLOR, F. W. Princípios da administração científica. São Paulo: Atlas, 1995

[35] TOYOTA MOTOR CORPORATION GLOBAL, Disponível em <htto;//www.toyota.co.jp/em/index.html> acesso 02 de junho de 2020. 


\section{Capítulo 4}

\section{Estudo de ruptura em talude na rua encontro das águas no Bairro Mauazinho - Manaus}

\section{Luana Silva de Souza \\ Nathália Aquino de Lima \\ Luciane Farias Ribas}

\section{Sara Santarém}

Resumo: As rupturas em taludes são responsáveis por inúmeros prejuízos causados à sociedade, sendo necessário o estudo dos fatores que influenciam na instabilidade dos mesmos. Para enfatizar a importância da análise de estabilidade, este estudo tem por objetivo avaliar a mudança nos planos críticos de ruptura do talude e a influência da evolução da ocupação local em área de risco. Para isso foram calculadas as tensões atuantes no solo para a determinação do Fator de Segurança, utilizando o software Slide. A análise foi feita na condição de saturação em um talude localizado na cidade de Manaus, às margens do rio Negro, na rua Encontro das Águas, no bairro Mauazinho. Como resultado, o estudo avaliou que o aumento da ocupação influencia na diminuição do fator de segurança por meio do aumento de áreas adjacentes, sem um sistema de drenagem eficiente, contribuindo para o aumento de sobrecarga ao longo do talude. Os resultados dos FS foram menores que o exigido pela NBR 11682/2009, independente das condições analisadas.

Palavras chave: Estabilidade, talude, Fator de Segurança, ruptura. 


\section{INTRODUÇÃO}

A ocupação urbana desordenada tem sido uma das principais barreiras a serem enfrentadas em relação ao desenvolvimento urbano, onde a população com menor poder aquisitivo acaba estabelecendo suas residências em áreas menos valorizadas, em terrenos localizados em espaços que apresentam riscos geológicos, sendo comum, notícias de deslizamentos de encostas que geram perdas humanas e prejuízos materiais.

O bairro Mauazinho, na cidade de Manaus, é proveniente de ocupação urbana desordenada devido à criação da Zona Franca, no Distrito Industrial da cidade, no final da década de 1960. Possui terreno irregular, fator resultante de duas bacias hidrográficas localizadas ao longo da extensão do bairro. Como consequência dessas irregularidades no solo, boa parte da sua área é caracterizada como sendo de risco dado à grande quantidade de encostas, fundos de vales ou áreas sujeitas a alagação. Nessas áreas que se encontram boa parte das ocupações, onde há inúmeras construções correndo risco principalmente dado a ação da movimentação do solo. Há, também, outros fatores que agravam a estabilidade das encostas, como por exemplo, a falta de sistema de drenagem e as ações antrópicas, com o descarte de lixo (lixeiras viciadas).

Tendo em vista a problemática do bairro, busca-se estudar a estabilidade de um talude situado na rua Encontro das Águas, no bairro Mauazinho, em Manaus, que se encontra, de acordo com os órgãos de fiscalização responsáveis, em área de risco. Estando às margens do Rio Negro, o talude abriga diversas moradias ao seu redor além de possuir duas escolas em sua crista.

\section{REVISÃO BIBLIOGRÁFICA}

Taludes compreende-se quaisquer superfícies inclinadas que limitam um maciço de terra, rocha ou de terra e rocha (CAPUTO, 2015). Sua estrutura é dividida em pé, talude (sendo este formado com certo ângulo de inclinação) e coroamento ou crista (Figura 1).

Figura 1: Composição de um talude.

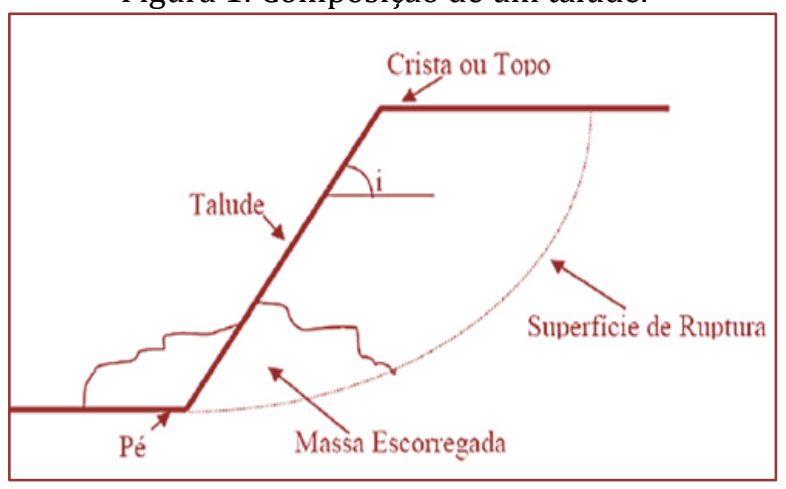

Fonte: Londe e Bitar, 2011

Segundo Gerscovish (2012), os taludes artificiais são resultados dos cortes em encostas, escavações ou aterros. Para a execução de corte em talude, é necessário a verificação da estabilidade do mesmo quanto, da altura e inclinação adequada para o corte, enquanto que taludes provenientes de aterros não apresentam tanta instabilidade pois suas características são conhecidas previamente para sua utilização.

Gerscovich (2012) explica que a vegetação pode ter um papel duplo nas encostas, podendo ser favorável ou desfavorável a estabilidade desses maciços. Antes da avaliação da vegetação em taludes como sendo importante para estabilização é importante explicar que a vegetação pode contribuir tanto beneficamente para a estabilidade de superfície inclinada quanto para desestabilização da mesma.

Tabalipa e Fiori (2008), explicam que na avaliação da cobertura vegetal para estabilidade de taludes alguns parâmetros devem ser considerados como por exemplo a pressão exercida pelos ventos sobre a vegetação que são transmitidas ao solo no somatório de forças cisalhantes, sendo a contribuição das raízes para a coesão do solo onde o contato raiz-solo aumenta a resistência ao cisalhamento contra possíveis escorregamentos. 
Resistência ao cisalhamento é a capacidade de suporte de carga que o solo tem para manter sua estabilidade. Então, quando uma força ultrapassa a capacidade desse solo em manter-se estável, ocorre a ruptura (CAPUTO, 2015). Dada a equação de Coulomb, para a resistência ao cisalhamento, existem dois fatores que são determinantes para obtenção do seu valor, a coesão e o ângulo de atrito interno (CAPUTO, 2015), demostrado pela equação de resistência:

$$
\tau=c+\sigma \cdot \operatorname{tg} \phi
$$

Onde:
( $\tau)$ resistência ao cisalhamento,
(c) coesão,
$(\phi)$ ângulo de atrito interno e;
$(\sigma)$ tensão normal.

Caputo (2015), ainda explica que apenas pressões efetivas são importantes para a resistência ao cisalhamento, podendo ser verificado pela equação de resistência de Terzaghi,

$$
\tau_{r}=c^{\prime}+(\sigma-u) \cdot \operatorname{tg} \phi^{\prime}
$$

Onde:

(u) pressão neutra ou poropressão,

(c') coesão efetiva e;

( $\phi ’$ ) ângulo de atrito interno efetivo.

0 mesmo autor indica que, quando uma força horizontal aplicada sobre as partículas do solo é maior que a força normal, pode-se descrever o coeficiente de atrito da seguinte forma:

$$
T_{h}=N_{v} \cdot \operatorname{tg} \phi
$$

Onde:
$\left(\mathrm{T}_{\mathrm{h}}\right)$ força horizontal $\mathrm{e}$;
$\left(\mathrm{N}_{\mathrm{v}}\right)$ força vertical.

No solo, as partículas podem se compactar, acomodando-se em vazios, mas Caputo (2015) também atenta para a diferença entre o contato de argilas, que tem o formato lamelar, e areias, com formato arredondado, onde a compactação dessas pode não expulsar completamente a água existente no solo.

Representado pelo coeficiente angular da reta, o ângulo de atrito interno, que passa na origem das coordenadas cartesianas, onde a reta simboliza os limites entre as regiões estáveis e instáveis, é chamado de linha de ruptura.

A coesão, característica de solos argilosos, é a capacidade que o solo tem de manter-se unido, podendo assim ser cortado sem se fragmentar, permanecendo indeformável (CAPUTO, 2015). Já os solos não coesivos, como as areias, ao serem fragmentados esfarelam-se pois possuem apenas uma coesão aparente. 
A pressão capitar da água no solo resulta na coesão aparente, e age como uma pressão externa. Nessas condições, explica Gerscovich (2012), a estabilidade de taludes exige a existência de uma grande área de contato entre as partículas de água e ar que fornecem a coesão aparente do solo. Assim, por exemplo, a água da chuva que percola ao longo da superfície íngreme da encosta, não desloca quantidade de ar suficiente que possa desestabilizar a coesão aparente do solo. Mas se água percola com muita intensidade e sem interrupção na superfície, os poros de ar serão quase que completamente preenchidos, eliminando a coesão aparente e o talude entrará em colapso.

Para Gerscovich (2012) analisar a estabilidade de taludes consiste em fazer uma comparação entre tensão cisalhantes, forças que atuam para o tombamento ou deslizamento do talude, e a resistência ao cisalhamento, força que atuam contra o tombamento ou deslizamento.

O fator de segurança (FS) é a razão entre as forças ou momentos que tendem a resistir ao deslizamento e as forças e momentos que tendem a gerar deslizamentos.

$$
\mathrm{FS}=\underset{\sum \text { Forças Resistentes }}{\sum \text { Forças Cisalhantes }} \rightarrow \mathrm{FS}=\frac{\sum \mathrm{Fr}}{\sum \mathrm{Fd}}
$$

$$
\mathrm{FS}=\frac{\sum \text { Momentos Resistentes }}{\sum \text { Momentos Cisalhantes }} \rightarrow \mathrm{FS}=\frac{\sum \mathrm{Mr}}{\sum \mathrm{Md}}
$$

A NBR 11682 (ABNT, 2009) oferece parâmetros para avaliação dos riscos de perdas humanas (Tabela 1) e

\begin{tabular}{|c|c|}
\hline $\begin{array}{l}\text { Nível de } \\
\text { Segurança }\end{array}$ & Critérios \\
\hline Alto & $\begin{array}{l}\text { Áreas com intensa movimentação e permanência de pessoas, como edificações públicas, residenciais } \\
\text { ou industriais, estádios, praças e demais locais, urbanos ou não, com possibilidade de elevada } \\
\text { concentração de pessoas. Ferrovias e rodovias de tráfego intenso. }\end{array}$ \\
\hline Médio & $\begin{array}{l}\text { Áreas e edificações com movimentação e permanência restrita de pessoas. Ferrovias e rodovias de } \\
\text { tráfego moderado. }\end{array}$ \\
\hline Baixo & $\begin{array}{l}\text { Áreas e edificações com movimentação e permanência eventual de pessoas. Ferrovias e rodovias de } \\
\text { tráfego reduzido. }\end{array}$ \\
\hline
\end{tabular}
de danos materiais (Tabela 2).

Tabela 1: Nível de segurança contra perdas de vidas.

\begin{tabular}{|c|c|}
\hline $\begin{array}{l}\text { Nível de } \\
\text { Segurança }\end{array}$ & Critérios \\
\hline Alto & $\begin{array}{l}\text { Danos: materiais: Locais próximos a propriedades de alto valor histórico, social ou patrimonial, obras } \\
\text { de grande porte e áreas que afetem serviços essenciais. } \\
\text { Danos ambientais: Locais sujeitos a acidentes ambientais graves, tais como nas proximidades de } \\
\text { oleodutos, barragens de rejeitos e fábricas de produtos tóxicos. }\end{array}$ \\
\hline Médio & $\begin{array}{l}\text { Danos materiais: Locais próximos e propriedades de valor moderado. } \\
\text { Danos ambientais: Locais sujeitos a acidentes ambientais moderados. }\end{array}$ \\
\hline Baixo & $\begin{array}{l}\text { Danos materiais: Locais próximos e propriedades de valor reduzido. Danos ambientais: Locais } \\
\text { sujeitos a acidentes ambientais reduzidos. }\end{array}$ \\
\hline
\end{tabular}
Fonte: adaptado NBR 11682 (ABNT, 2009).

Tabela 2: Nível de segurança contra danos materiais e ambientais. Fonte: Adaptado NBR 11682 (ABNT, 2009).

Após a análise e classificação de acordo com as tabelas 1 e 2, os níveis de segurança podem ser obtidos na Tabela 3. 
Tabela 3: Nível de segurança contra danos a vida humana.

\begin{tabular}{|c|c|c|c|}
$\begin{array}{c}\text { Nível de segurança contra danos } \\
\text { materiais e ambientais } \\
\text { Nível de segurança contra danos a } \\
\text { vidas humanas }\end{array}$ & Alto & Médio & Baixo \\
\hline Alto & 1,5 & 1,5 & 1,4 \\
\hline Médio & 1,5 & 1,4 & 1,3 \\
\hline Baixo & 1,4 & 1,3 & 1,2 \\
\hline
\end{tabular}

Fonte: Adaptado NBR 11682 (ABNT, 2009).

O fator de segurança pode ser medido por inúmeros métodos, entre eles, o método de Fellenius. Para alcançar o resultado ofertado por este método, o cálculo do Fator de Segurança pode utilizar os parâmetros envolvidos na análise de estabilidade (Equação 6), onde Fellenius desenvolveu o método baseado no volume de solo situado acima da superfície de ruptura, dividindo-a em fatias (Gerscovich, 2012).

$$
\mathrm{FS}=\frac{\sum\left[\mathrm{c}^{\prime} \cdot 1+\operatorname{tg} \varphi^{\prime}(\mathrm{P} \cdot \cos \alpha-\mathrm{u} \cdot \mathrm{l})\right]}{\sum \text { P.sen } \alpha}
$$

Onde:

(c') coesão efetiva,

( $\left.\phi^{\prime}\right)$ ângulo de atrito interno efetivo,

(P) peso do solo,

(u) pressão neutra ou poropressão,

(l) comprimento da fatia de solo.

Outro método, conhecido como Jambu, descreve o maciço de solo e sua divisão em fatias infinitesimais, onde é feito o equilíbrio de força e momentos em cada lamela. 0 mesmo dispõe de um método simplificado e outro rigoroso, sendo necessário a utilização de programas computacionais para resultado do Fator de Segurança (Gerscovich, 2012) (Equação 7).

$$
\mathrm{FS}=\mathrm{fo} \sum\left[\mathrm{c}^{\prime} \cdot \mathrm{b}+(\mathrm{P}-\mathrm{u} \cdot \mathrm{l}) \frac{\left.\operatorname{tg} \varphi^{\prime}\right] 1 / \mathrm{N} \alpha}{\sum \text { P.tg } \alpha}\right.
$$

Onde:

(fo) fator de correção,

(c') coesão efetiva,

$\left(\mathrm{N}_{\alpha}\right)$ parâmetro que depende da geometria, ?

( $\phi$ ') ângulo de atrito interno efetivo,

(P) peso do solo,

(u) pressão neutra ou poropressão e;

(b) base da fatia de solo. 
Um outro método utilizado para o Fator de Segurança é descrito como método simplificado de Bishop, resultado do equilíbrio de momentos onde a solução é resultante de um processo iterativo. No cálculo da Equação 8, inicialmente utiliza-se um valor de Fator de Segurança obtido no método de Fellenius para encontra o valor do Momento M $\alpha$ (Fiori, 2015).

$$
\mathrm{M} \alpha=\cos \alpha\left[1+\left(\operatorname{tg} \varphi^{\prime} \cdot \operatorname{tg} \alpha / \mathrm{FSi}\right)\right]
$$

Onde:

(FSi) fator de segurança obtido do método de Fellenius,

( $\phi ’)$ ângulo de atrito interno efetivo.

Após isso, substituísse o valor de Ma encontrados na equação 9 do Fator de Segurança que este método propõe.

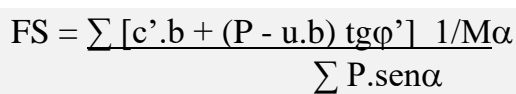

Onde:

(c') coesão efetiva,

$\left(\mathrm{M}_{\alpha}\right)$ momento,?

( $\phi$ ') ângulo de atrito interno efetivo,

(P) peso do solo,

(u) pressão neutra ou poropressão e

(b) base da fatia de solo.

Outro modelo é descrito pelo método de Spencer, considerado rígido dado a verificação de todas as equações de equilíbrio de forças e momentos, observando também, as forças entre as fatias, gerando assim dois fatores de segurança (Gerscovich, 2012), em que as forças precisam ser de inclinação constante entre as fatias, fazendo com que a força normal na base do talude (Equação 10).

$$
\mathrm{N}=\mathrm{P}-\left(\mathrm{E}_{\mathrm{R}}-\mathrm{E}_{\mathrm{L}}\right) \cdot \operatorname{tg} \varphi^{\prime}-\frac{1}{F S} \cdot\left(\mathrm{c}^{\prime} \cdot 1 \cdot \operatorname{sen} \alpha-\mathrm{u} \cdot 1 \cdot \operatorname{sen} \alpha\right) / \mathrm{M} \alpha
$$

Onde:

(N) força normal na base da fatia de comprimento l,

$\left(E_{R}\right)$ força horizontal entre fatias lado direito,

$\left(E_{L}\right)$ força horizontal entre fatias lado esquerdo

Agora a equação do FS pode ser determinada através do somatório de forças horizontais pela equação 11. 


\[ \mathrm{FS}_{\mathrm{f}}=\frac{\sum \mathrm{c}^{\prime} \cdot 1 \cdot \cos \alpha+(\mathrm{P}-\mathrm{u} \cdot \mathrm{l}) \cdot \operatorname{tg} \varphi^{\prime} \cdot \cos \alpha}{\sum \mathrm{P} \cdot \operatorname{sen} \alpha+\sum \mathrm{k} \cdot \mathrm{P} \pm \mathrm{A}-\mathrm{L} \cdot \cos \varpi} \]
Onde:
$\left(\mathrm{FS}_{\mathrm{f}}\right.$ fator de segurança relacionado às forças,
(K) coeficiente sísmico para determinar a força dinâmica horizontal,
(A) resultante da pressão de água nas fissuras,
(L) linha de força (força por unidade de comprimento) e
(๘) ângulo da linha de carga com a horizontal.

\section{METODOLOGIA}

Na primeira etapa do trabalho foi realizada uma visita técnica ao local para conhecimento da área ao entorno do talude e para realização de anotações. Despois foram levantados dados de imagens fornecidas pelo Software Google Earth para visualização de um possível crescimento das ocupações no seu entorno, nos anos de 2001 até 2018.

Houve a necessidade desta verficação para se obter respostas quanto a possibilidade de um aumento na ocupação aos redores do talude, visto que essas ocupações poderiam está gerando sobrecargas no solo, transmitidas através de um bulbo de tensões atuando como uma força a mais no somatório de forças resultantes de cisalhamento no solo. A partir disso, inicia-se os apontamentos a partir de 2001 dado o ano de publicação do primeiro estudo realizado no local, para verificação da estabilidade do talude, por Campelo (2001). Neste estudo, o autor adotou em suas análises, uma sobrecarga de $30 \mathrm{Kpa}$, considerando as duas escolas e a torre de alta tensão.

Na segunda etapa, foram realizados cálculos para determinar os valores das tensões totais verticais, poropressão e as tensões efetivas atuantes nas camadas de solo do talude. A tensão total se caracteriza pelo efeito do peso específico do solo atuando em uma determinada camada de solo, a poropresão apresenta a atuação da água no solo e a tensão efetiva que apresenta atrito entre as camadas. Para auxiliar nos cálculos das tensões, foi utilizado o programa Microsoft Excel, com os pontos analisados, a profundidade de cada camada e seus respectivos pesos especificos de solo.

Em seguida configuramos o programa Excel para a realização das seguintes equações:

- Tensão Total

$$
\sigma=\gamma_{\mathrm{s}} . \mathrm{hs}
$$

Poropressão

$$
\mathrm{u}=\gamma_{\mathrm{a}} \cdot \mathrm{h}_{\mathrm{a}}
$$

- Tensão efetiva:

$$
\sigma^{\prime}=\sigma-u
$$

Após identificação das tensões atuantes no solo, foram realizadas as verificação das análises de ruptura por meio de simulações computacional.

Na terceira parte foram feitas simulações no software Slide, usando como base os dados geométricos e de resistência do solo. Considerou-se ainda as análises das pressões atuantes pelo peso do solo e a presença da água no talude na condição saturada. O programa computacional empregado para avaliar a possibilidade de ruptura do talude na condição saturada a partir de um valor do fator de segurança, foi o software Rocscience Slide versão 6.0. Este software permite integrar em suas analises as ações hidráulicas como por exemplo poropressão, nível d'água e, para o caso estudado, a cota do rio que exerce influência direta no talude.

Para configuração do software, foi necessário representar a geometria do talude de forma mais aproximada do real. Para isso utilizou-se as informações de altura e base do talude apresentados na 
bibliografia de Campelo (2001). Para a melhor representação computacional do comportamento do talude (Figura 2), foram configuradas as cotas de profundidades das camadas e os parâmetros de resistência do solo. Além de inseridos os resultados das equações de tensões (equações 12, 13 e 14) obtidas anteriormente.

Figura 2: Apresentação das configurações de propriedades de cada camada.

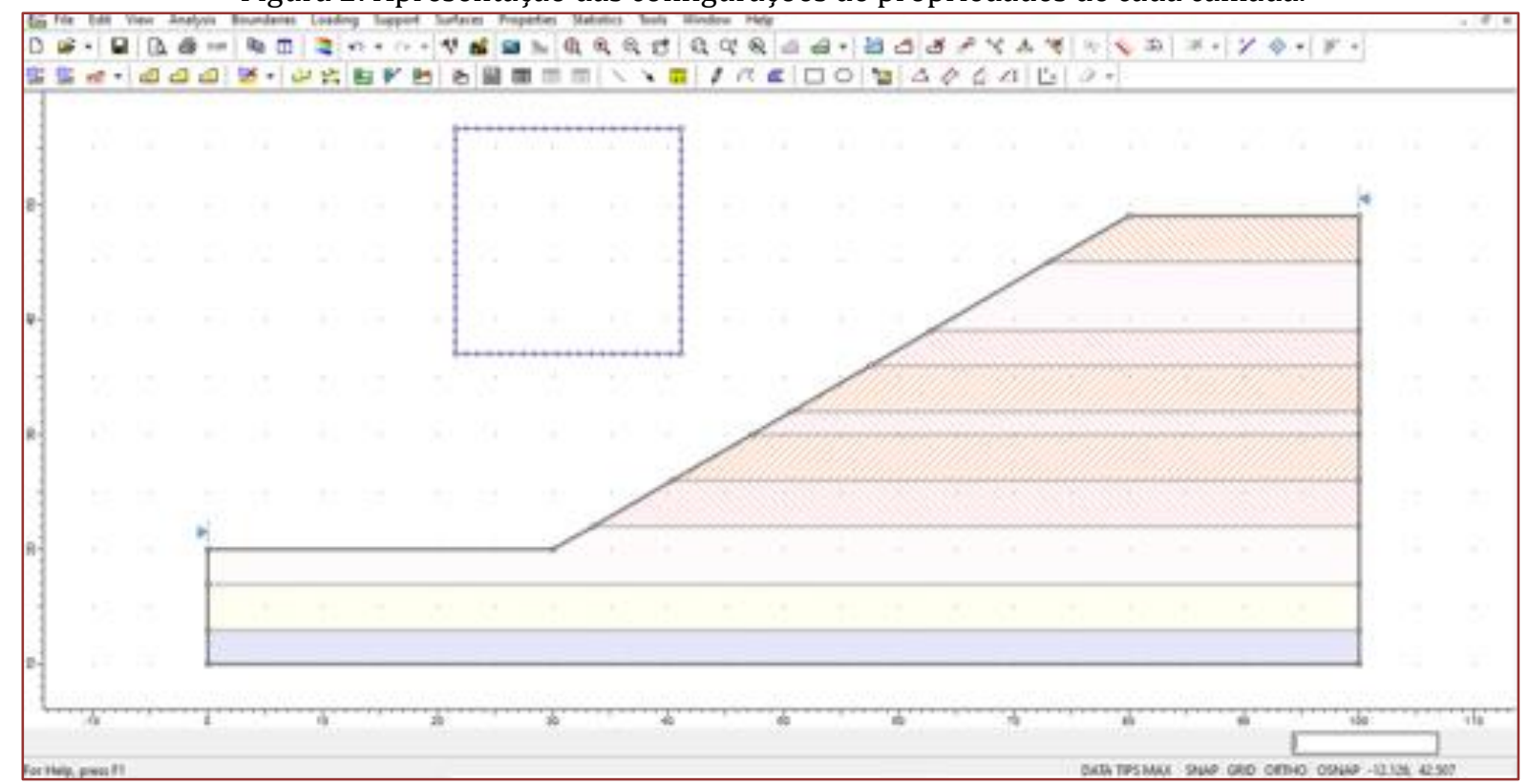

Fonte: Autoria própria, 2019.

Assim, o software permite a configuração de métodos de análises de estabilidade e os números de interações que o software deve realizar para encontrar o Fator de Segurança. Para este estudo foram escolhidos quatro métodos de cálculo diferentes para análise de estabilidade do fator de segurança, sendo os métodos de Fellenius, Spencer, Bishop e Jambu Simplificado.

Durante o periodo deste estudo houve um deslizamento do talude que modificou sua caracteristica geométrica, antes observada. Por isso, as análises foram feitas virtualmente com e sem o acréscimo de sobrecarga, antes e depois de do deslizamento.

\section{RESULTADOS E DISCUSSÕES}

\subsection{ANÁLISE DA EVOLUÇÃO DA OCUPAÇÃO URBANA NA ÁREA DE INFLUÊNCIA DO TALUDE}

Na verificação da evolução da ocupação, delimitou-se um raio de influência de 60 m do ponto de estudo, para identificação de um possível aumento da taxa de ocupação na região que pudesse ter modificado o coeficiente de segurança do talude em decorrência da sobrecarga exercida a partir das tensões transmitidas ao solo, fazendo assim uma comparação com o estudo de Campelo (2001), onde o mesmo considerou para sua análise de determinação do FS, uma sobrecarga de $30 \mathrm{KPa}$ levando em consideração o peso das escolas, torre de alta tensão e residências das proximidades.

Utilizando o histórico de imagens do Google Earth para comparação dos pontos de ocupação de 2001 até 2018 (Figura 3a e 3b) pode-se observar a grande expansão da ocupação do solo em várias áreas dentro do bairro. Mas dentro da zona de observação na crista do talude, identificado com o círculo amarelo na figura b, não apresentou novas construções na área que diferenciassem de forma significativa dos resultados obtidos em 2001, no estudo apresentado por Campelo (2001).

Não vi o círculo amarelo!!! Acho que precisa das coordenadas! 
Figura 3: Imagem de satélite da área do Mauazinho a) ocupação em 2001; b) ocupação em 2018.
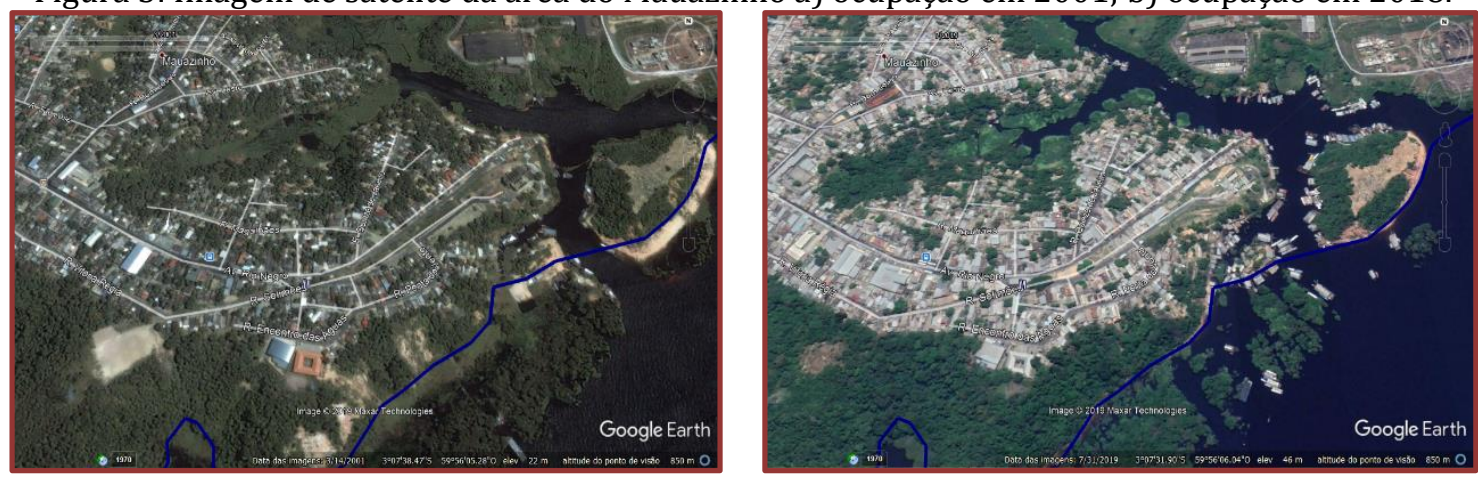

Fonte: Google Earth, 2019.

Portanto, a ocorrência de ruptura em razão de excesso de carga transmitida por fundações dentro da zona critica analisada não é considerável até o presente momento. É de fundamental importância chamar a atenção para alguns fatores possíveis de desestabilização, a vegetação que compõe o talude e o excesso de áreas impermeabilizadas sem drenagem suficiente.

A vegetação que compõe toda a extensão íngreme do talude pode ser um fator de desestabilização devido as tensões cisalhantes causadas pelo peso dos caules das árvores que em dias de precipitação de longa ou intensa duração, que são recorrentes em Manaus devido calor e umidade atuam diretamente na encosta do talude juntamente com a incidência de ventos sobre as árvores podem influenciar em aumento na sobrecarga no solo.

A sobrecarga no solo que ocorre por um período de intensa precipitação torna-se um fator ainda mais preocupante pois com o aumento da ocupação desordenada em várias áreas no bairro Mauazinho, nota-se ainda um aumento das áreas impermeabilizadas sem sistema de drenagem eficiente. Durante a visita técnica feita na rua Encontro das Águas, não foram encontrados nenhum ponto de drenagem de águas. Assim, em período de chuvas intensas, parte da água acumulada ao longo da rua escoa para o talude atuando no aumento da saturação, que somados com o peso da vegetação podem atuar com aumento de sobrecargas.

Nessas condições, seria de grande importância a atuação de um programa de infraestrutura e drenagem como o Requalifica Manaus. Este programa já atuou no bairro, mas apenas obras de recapeamento asfáltico foram feitas nas principais vias do bairro. Na rua Encontro das Águas, é preciso a execução de novos pontos de drenagem, para o rápido escoamento das águas pluviais e diminuição do excesso de água acumulada no solo, assim como a construção de uma contenção na zona crítica de ruptura do talude estudado.

\subsection{DETERMINAÇÃO DAS TENSÕES NO SOLO}

Na figura 4, são apresentados os resultados dos cálculos de tensão total, poropressão e tensão efetiva.

Figura 4: Resultado da tensão total, poropressão e tensão efetiva no talude.

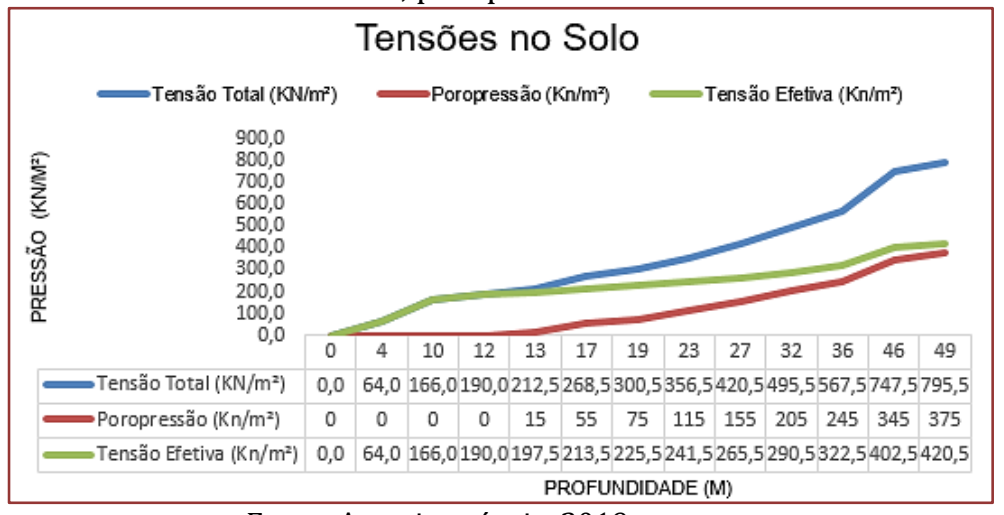

Fonte: Autoria própria, 2019. 
Observando os resultados apresentados na figura 4 é possível verificar que a tensão que atua efetivamente sobre os planos horizontais das camadas de solo não saturados, foram produzidas pelo somatório do peso próprio do solo atuante até o nível d'água à cota de $-13,0 \mathrm{~m}$ de profundidade. Assim, justifica-se que os valores das tensões totais também tenham sido iguais aos das tensões efetivas pois no somatório das tensões totais atuantes até a cota do NA, não foi incorporado a atuação de poropressões provocadas pelo peso da água, entre as partículas de solo.

Todavia, a partir da cota de $-13,0 \mathrm{~m}$, as linhas de tensões totais e efetiva apresentam uma variação significativa devido ao aparecimento de poropressão, resultante da presença do nível d'água, atuando sobre as camadas inferiores e tornado o solo saturado. Com a incorporação da poropressão, o somatório das tensões totais considera todos os materiais presentes em cada camada de solo, tanto o peso do próprio solo quanto o peso da água, sendo representado com o aumento progressivo dos valores de tensões totais conforme o aumento da profundidade. Sendo assim as tensões que passam a atuar efetivamente em qualquer ponto no talude é caracterizado pela tensão efetiva.

\subsection{SIMULAÇÕES NO SOFTWARE SLIDE}

Os resultados obtidos foram avaliados utiizando a cota de 26,0 m do rio Negro, registrada no mês de setembro deste ano, para reproduzir de forma mais aproximada as condições de tensões que atuavam sobre o talude no periodo em que ocorreu o deslizamento ainda durante a realização deste estudo.

As simulações apresentas a seguir nos itens 4.3.1 e 4.3.2, mostram os resultados dos métodos que apresentaram os menores valores FS, antes e depois do deslizamento, sem e com sobrecarga.

\subsubsection{ANTES DO DESLIZAMENTO}

Para as duas primeiras análises foi utilizado o perfil mostrado na Figura 5, antes da ocorrência do deslizamento, com e sem sobrecarga transmitidas ao solo.

Figura 5: Geometria utilizada para as duas primeiras analises 1 e 2.

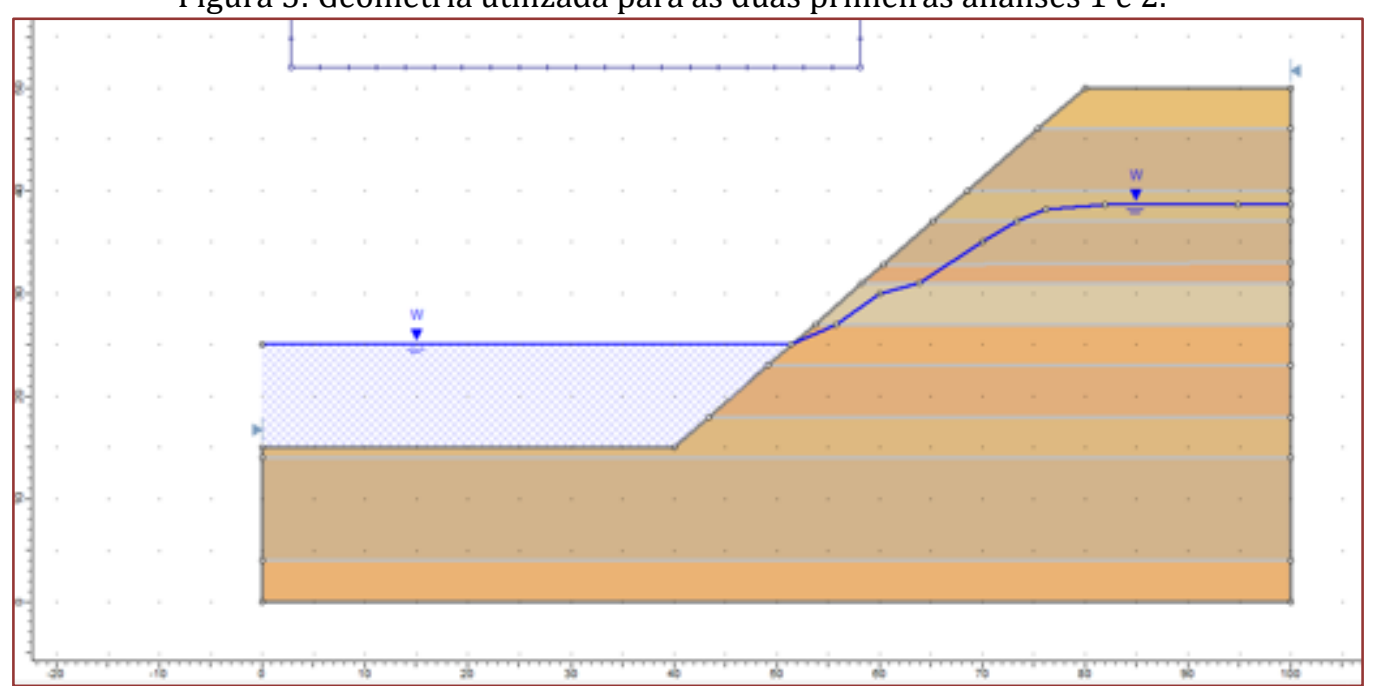

Fonte: Autoria própria, 2019.

1o Análise de FS:

Na primeira análise considerando apenas o peso do maciço de solo e mais as tensões de poropressão, o valor mais desfavorável à estabilidade foi apresentado pelo método de Jambu, $\mathrm{FS}=0,682$. Mostrando dentro da superfície de ruptura que as maiores tensões se apresentam no topo e na base do talude (Figura 6). 
Figura 6: Fator de Segurança mais baixo encontrado para a primeira condição de instabilidade.

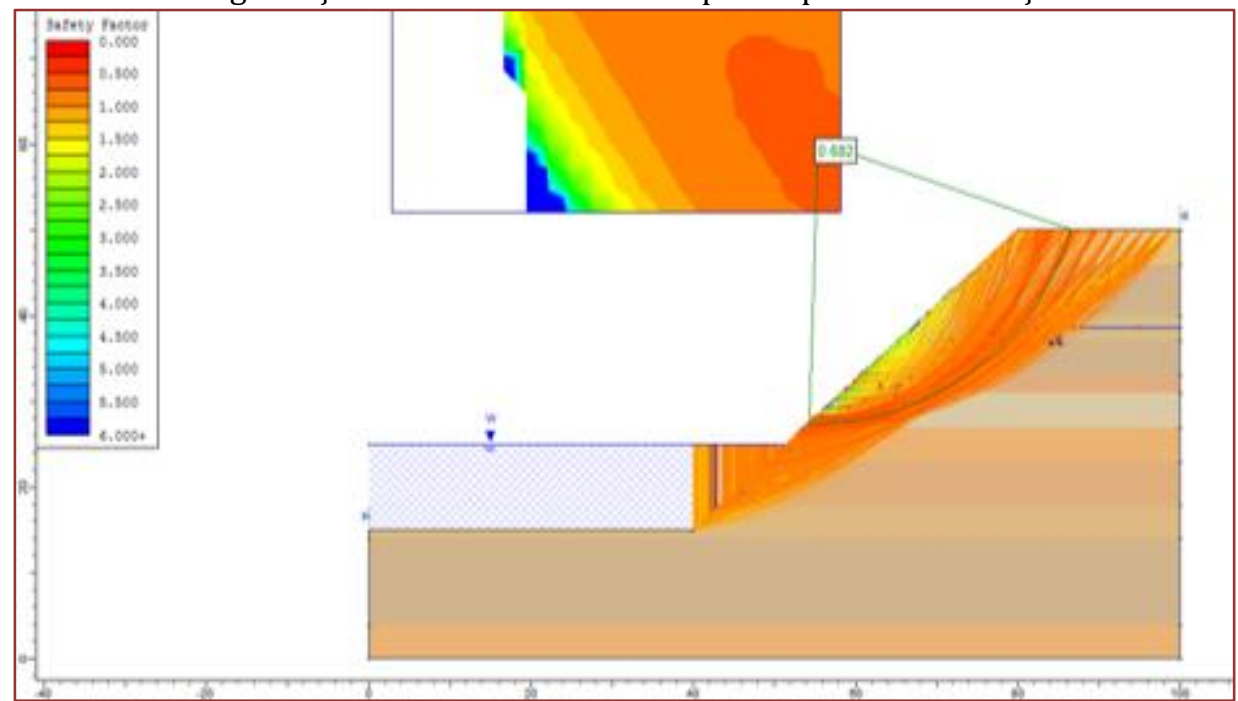

Fonte: Autoria própria, 2019.

2o Análise de FS:

A segunda análise, demonstrado na Figura 7, considerando a sobrecarga disposta no topo do talude, representando as duas escolas, juntamente com a torre de alta tensão. 0 método de Fellenius apresentou o resultado do FS=0,580, sendo o mais desfavorável e apresentando grandes concentrações de tensões cisalhantes na base e entorno superfície de ruptura.

Figura 7: Fator de Segurança mais baixo encontrado para a segunda condição de instabilidade.

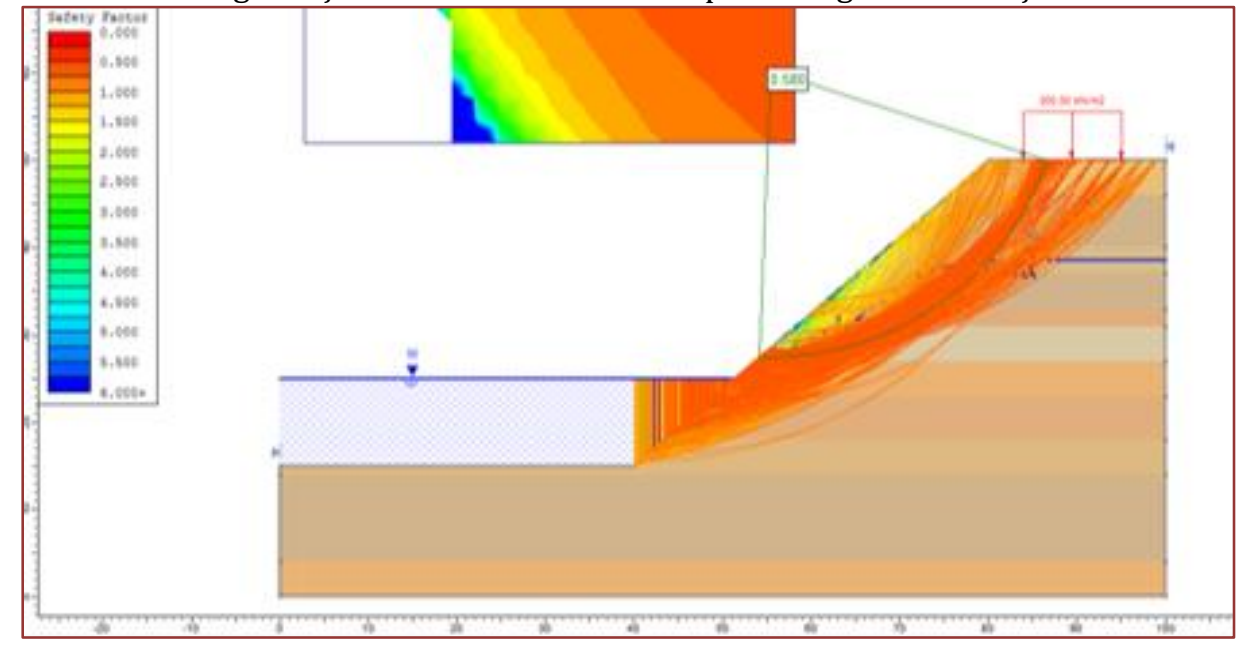

Fonte: Autoria própria, 2019.

\subsubsection{ANTES DO DESLIZAMENTO}

Estas simulações foram necessárias devido a ocorrência de um deslizamento, ocorrido no final do mês de setembro, onde aproximadamente $70 \mathrm{~cm}$ de espessura de solo desprenderam-se ao longo de 17,0 à 19,0 m do talude, deixando assim a zona crítica de ruptura à menos de $1,50 \mathrm{~m}$ de distância dos fundos da escola, no topo do talude.

Agora, para a análise das condições 3 e 4, a geometria do topo foi modificada, diminuindo a inclinação do talude de acordo com as dimensões já explicitadas, no parágrafo anterior (Figura 8). 
Figura 8: Geometria utilizada para as duas primeiras análises - 3 e 4.

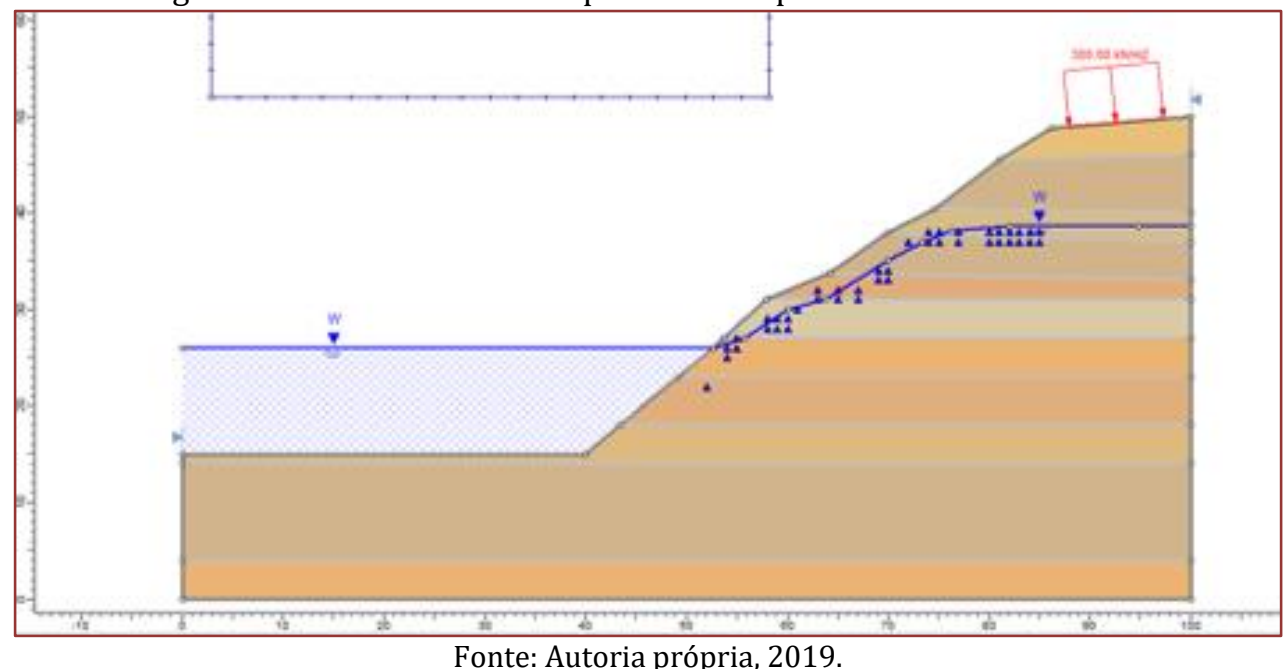

3o Análise de FS

Na terceira análise, considerando o deslizamento sem o acréscimo da sobrecarga, o método de Jambu apresentou o valor do FS=0.787 mais desfavorável à estabilidade. Todavia, é notável uma mudança quanto as distribuições de tensões de ruptura após o deslizamento. Observa-se, que houve aumento das tensões resistentes do solo em resposta as cisalhantes, mas, ainda assim, muito abaixo do aceitável para a verificação de estabilidade (Figura 9).

Figura 9: Fator de Segurança mais baixo para a terceira condição de instabilidade.

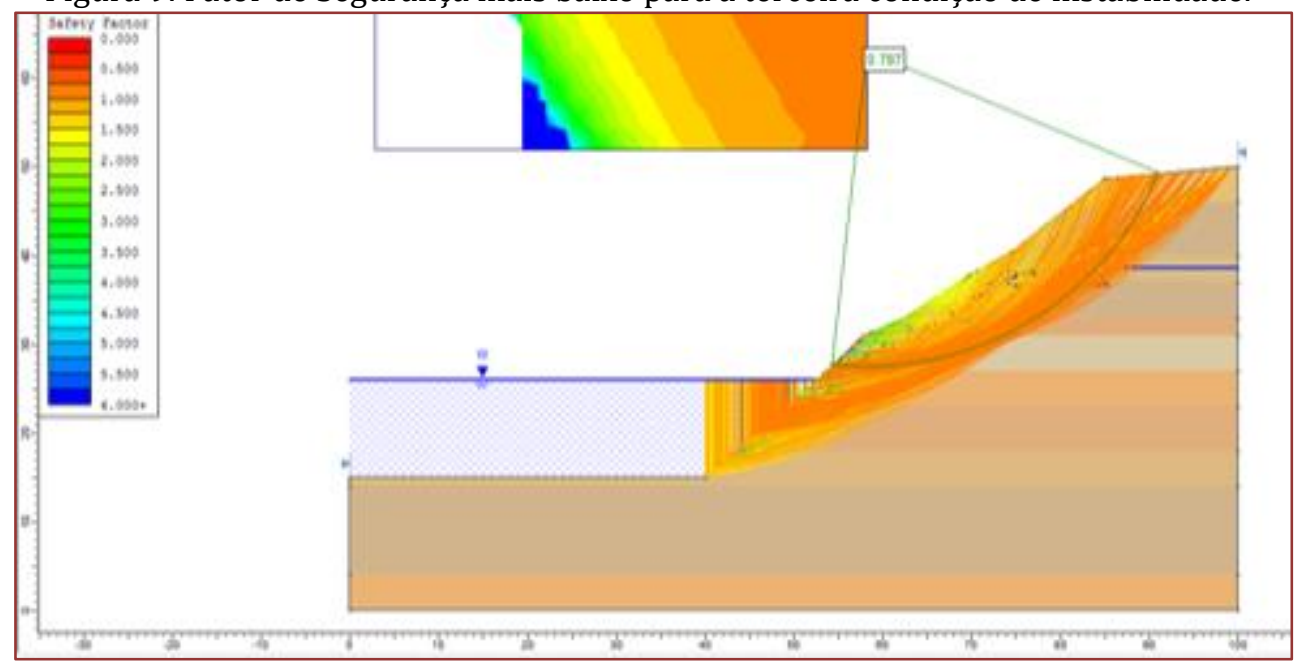

Fonte: Autoria própria, 2019.

\section{4ํAnálise de FS}

Na quarta análise, considerando o acréscimo da sobrecarga, o método de Jambu apresentou o FS = 0.667 sendo o mais desfavarável (Figura 10). Contudo, na análise foi verificado um aumento na profundidade de atuação das tensões aplicadas ao solo em comparação com a análise 2. 
Figura 10: Fator de Segurança mais baixo encontrado para a quarta condição de instabilidade.

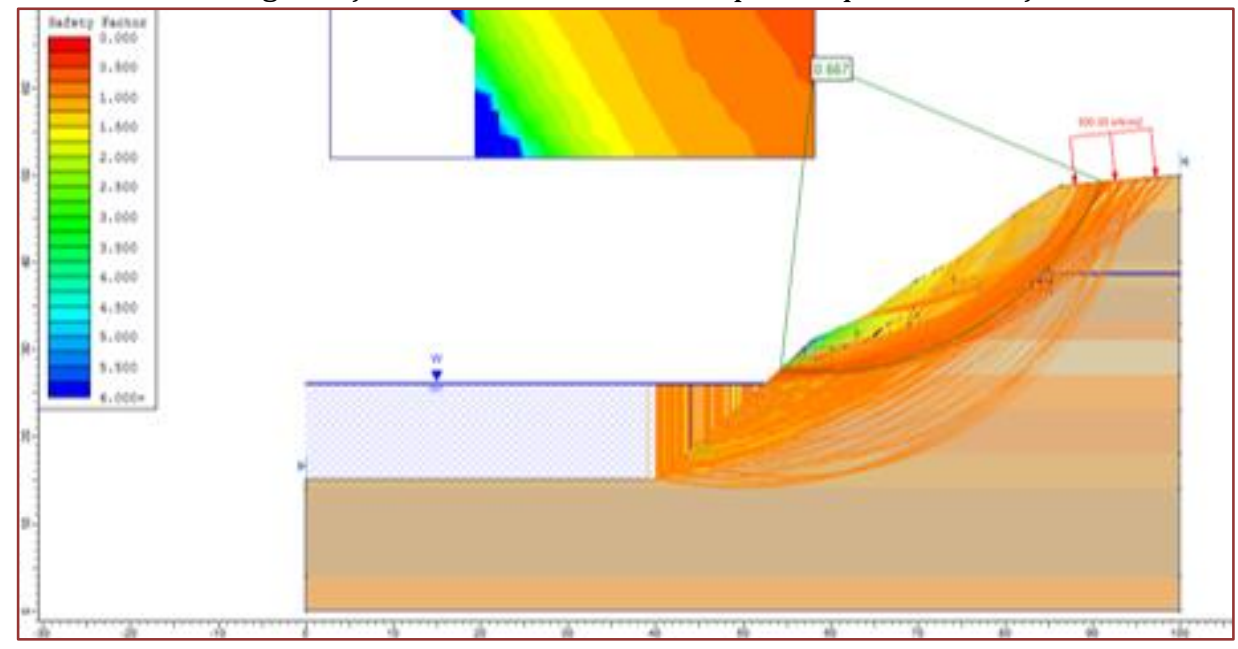

Fonte: Autoria própria, 2019.

\subsubsection{SIMULAÇÕES - RESUMO}

A Tabela 4 apresenta os resultados obtidos por meio dos métodos de Fellenius, Bishop, Jambu e Spencer.

Tabela 4: Resultado dos Fatores de Segurança, utilizando quatro diferentes métodos.

\begin{tabular}{|c|c|c|c|c|}
\hline \multirow{2}{*}{ CONDIÇÃO } & \multicolumn{4}{|c|}{ FATOR DE SEGURANCCA } \\
\hline & Fellenius & Bishop & Jambu & Spencer \\
\hline FS antes do deslizamento e sem sobrecarga & 0.697 & 0.684 & 0.682 & 0.718 \\
\hline FS antes do deslizamento e com sobrecarga & 0.580 & 0.614 & 0.559 & 0.616 \\
\hline FS após deslizamento e sem sobrecarga & 0.807 & 0.808 & 0.787 & 0.818 \\
\hline FS após deslizamento e com sobrecarga & 0.687 & 0.717 & 0.667 & 0.730 \\
\hline
\end{tabular}

Fonte: Autoria própria, 2019.

Nos resultados apresentados na Tabela 4, observa-se que os métodos apresentaram valores desfavoráveis, e ainda aproximados do FS aceitável de 1,5 para estabilidade de acordo com o recomendado pela NBR $11682 / 2009$.

Os fatores de segurança obtidos pelas simulações antes do deslizamento, com e sem sobrecarga, apresentaram valores baixos, dado pela inclinação acentuada no topo do talude e às altas tensões concentradas principalmente na linha de ruptura.

Comparando os quatro métodos entre si, alguns resultados apresentaram pouca diferença, em determinadas análises a diferença sendo verificada apenas na terceira casa decimal dos coeficientes. Assim como ocorreu na verificação do FS antes do deslizamento e sem a sobrecarga, entre os valores de FS de Bishop e Jambu, apresentando respectivamente 0.684 e 0.682 . Em seguida, na verificação com a sobrecarga, entre os valores de Bishop e Spencer apresentando respectivamente 0.614 e 0.616 . E na verificação após o deslizamento e sem a sobrecarga, entre Fellenius e Bishop, apresentando FS de 0.807 e 0.808 , respectivamente.

Dos quatro métodos, o que a presentou os maiores valores de FS em todas as análises, foi o método de Spencer, visto que a característica deste método, possibilita o software realizar mais interações entre as fatias, em que calcula-se todas as variáveis existentes e as variáveis relacionadas como: as forças horizontais, verticais, tangenciais e momento.

Avaliando as simulações, é possível verificar a real necessidade da construção de uma contenção na zona de ruptura. Os valores de FS são tão baixos, que mostram que os deslizamentos continuarão ocorrendo motivado por diversos fatores, que tornam o talude cada vez mais instável e deixando muitas pessoas vulneráveis, pois a área que mais apresenta risco fica a menos de 1,50 m, como já explicado no item 4.3.2. 


\section{CONCLUSÃO}

A contribuição da evolução da ocupação na diminuição do FS não ocorreu diretamente pelo adensamento de novas edificações no entorno do talude, mas sim pelo avanço das áreas impermeabilizadas que não receberam a implantação de sistema de drenagem para captação do fluxo de águas pluviais.

Levando em consideração o risco imposto pelas condições de instabilidade do talude é necessário a construção de estrutura para contenção das superfícies de ruptura, e também para a drenagem das águas pluviais que podem afetar diretamente a superfície do talude, atuando no aumento da poropressão devido a infiltração e permeabilidade, resultando assim na diminuição dos valores das tensões efetivas calculadas.

Outro ponto é a relação da vegetação encontrada no talude com a estabilidade do mesmo dentro da superfície de ruptura, em anos anteriores a presença da vegetação fazia-se presente na superfície inclinada do talude, e mesmo assim o processo de deslizamento ocorreu entendendo-se que a vegetação neste caso, atuou como uma força a mais no somatório das tensões cisalhantes.

Sobre o software Slide utilizado para as verificações de estabilidade do talude, apresenta uma interface muito simples de ser interpretada pelo usuário. As verificações feitas incorporando a análise da influência da água no solo foi de grande valia para a interpretação matemática da realidade do comportamento do talude que localiza na orla do rio Negro.

Nas análises realizadas, utilizando o software, foi identificado uma variação dos valores dos fatores de segurança utilizando quatro métodos diferentes para os cálculos. Os valores obtidos dos FS mostraram que independentemente das condições impostas para o cálculo, os resultados dos FS foram menores que o exigido pela NBR $11682 / 2009$, de FS = 1,5.

Portanto conclui-se que este estudo demostrou a existência de risco de ruptura iminente, devido à valores muito baixos observados dos fatores de segurança calculado, falta de contenção, drenagem ineficiente e vegetação inadequada manutenção da estabilidade do talude.

\section{REFERENNCIAS}

[1] _ _ NBR 11682: Estabilidade de encostas. Rio de Janeiro: ABNT, 2009

[2] CAMPELO, N. S. Estabilidade de taludes naturais localizados na orla do Rio Negro e no Polo Industrial. Universidade Federal do Amazonas, Manaus, 2001.

[3] CAPUTO, Homero P. Mecânica dos solos e suas aplicações. 6. ed. rev. ampl. Rio de Janeiro: LTC, 2015.

[4] GERSCOVICH, D.M.S. Estabilidade de Taludes. São Paulo: Oficinal de Textos 2012.

[5] LONDE, P.R.; BITAR, N.A.; Importância do uso de vegetação para contenção e combate à erosão em taludes do lixão desativado no município de Patos de Minas (MG). Perquirere, Patos de Minas. UNIPAM. 2011.

[6] TABALIPA, N.L.; FIORI, A.P. Influência da vegetação na estabilidade de taludes na bacia do rio Ligeiro (PR). Universidade Tecnológica Federal do Paraná, UTFPR. Pato Branco, São Paulo. 2008. 


\section{Capítulo 5}

\section{Estudo de caso da execução de paredes de concreto para habitação de baixa renda}

\section{Manoel Oliveira de Albuquerque Junior \\ Sara dos Santos Santarém \\ Luciane Farias Ribas \\ Frank Henrique Santos Fontineles}

Resumo: No Brasil, retornou o crescimento do sistema construtivo de paredes de concreto moldadas no local, gerando facilidades na construção de moradias em grande escala, com tempo reduzido. Para que houvesse padronização no planejamento e execução, foram criadas normas destinadas aos responsáveis pelos projetos e realização do sistema. Este artigo tem como objetivo geral apresentar as etapas de execução do sistema construtivo parede de concreto no "Programa Minha Casa Minha Vida", por meio de estudo de caso, analisando etapas construtivas e falhas construtivas durante o procedimento. A metodologia utilizada foi estudo de caso, numa obra na Cidade de Manaus, sendo um condomínio residencial vertical contendo 20 blocos, cada bloco possuindo cinco pavimentos, 40 unidades habitacionais, totalizando 800 moradias executadas com o método de paredes de concreto moldadas no local. Foi realizado uma entrevista com o engenheiro responsável pelo empreendimento, levantamento as principais dificuldades no processo executivo, os erros mais comuns identificados nas etapas e as patologias mais relevantes apresentadas na estrutura das paredes concretadas. Com base na entrevista desenvolvida e em outros dados, foi possível apresentar os resultados obtidos neste trabalho referentes ao processo executivo de paredes de concreto.

Palavras-chave: Parede de concreto, patologias, execução 


\section{INTRODUÇÃO}

Nos últimos anos, a indústria da construção brasileira vive um momento singular, beneficiada pela grande demanda por edificações, pelo crescente acesso da população ao crédito e aos incentivos governamentais na diminuição do déficit habitacional do país. O programa Minha Casa Minha Vida (MCMV), do governo federal, proporcionou aos trabalhadores de renda salarial entre 0 a 3 salários mínimos a possibilidade de realizar o sonho da casa própria, através de financiamentos e subsídios oferecidos para a aquisição dos imóveis. Essa situação se tornou bastante positiva tanto para a sociedade quanto para os empreendedores. A partir disso, começou a ser exigido das construtoras maior foco em obras duráveis, realizadas dentro de padrões técnicos reconhecidos, com segurança estrutural, velocidade de execução e bom gosto estético.

O sistema de parede de concreto atende a todas as premissas do mercado, oferecendo as vantagens de uma metodologia construtiva voltada à produção de empreendimentos que têm alta repetitividade, como condomínios e edifícios residenciais. A qualidade final de uma obra está diretamente ligada aos materiais utilizados, aos métodos de execução e ao controle tecnológico que se faz, desde a produção dos insumos até sua aplicação.

Mesmo com o avanço das técnicas construtivas e o maior controle de qualidade dos materiais empregados, as edificações ainda apresentam diversas espécies de patologias. Grande parte das anomalias que geram patologias, são decorrentes ou do mau gerenciamento dos projetos, ou da má execução dos serviços.

Por isso o objetivo deste artigo é apresentar as etapas de execução do sistema construtivo parede de concreto no "Programa Minha Casa Minha Vida", por meio de estudo de caso, analisando etapas construtivas e falhas construtivas durante o procedimento.

Para compreender melhor as potencialidades e limitações deste sistema construtivo será utilizado como estudo de caso um empreendimento que está sendo construído em Manaus, no estado do Amazonas, pela Direcional Engenharia. A intenção é a partir da observação na prática do sistema, verificar se as boas práticas são aplicadas no processo executivo, além de identificar os resultados caso a execução não seja realizada conforme as instruções passadas aos colaboradores em forma de treinamentos e exposição das normas técnicas específicas do método construtivo de paredes de concreto moldadas no local.

\section{REFERENCIAL TEÓRICO}

\subsection{SISTEMA CONSTRUTIVO DE PAREDE DE CONCRETO}

A norma NBR 16055 (2012), descreve a parede de concreto sendo um elemento estrutural autoportante, moldado no local, com comprimento maior que dez vezes sua espessura e capaz de suportar carga no mesmo plano da parede. Anaute (2012) aponta que o sistema construtivo em estudo desde 2007, pelo Grupo Parede de Concreto, abrigado na ABCP. Surgiu com a grande demanda, em função do programa MCMV. O Sistema Paredes de Concreto aproveitou o conhecimento desenvolvido, a demanda gerada pelo programa habitacional e a escala necessária, para se consolidar como o sistema mais importante, produtivo e econômico quando se trata em produção em larga escala.

Fernandes (2019), lembra que as normas indispensáveis para aplicação do método de fôrmas removíveis de maneira padronizada e segura são ABNT NRB 16055:2012 (Parede De Concreto Moldada No Local Para A Construção De Edificações - Requisitos e Procedimentos), ABNT NBR 6118:2014 (Projeto de Estruturas de Concreto), ABNT NBR 7481:1990 (Tela de Aço Soldada - Armadura para Concreto), a norma de desempenho ABNT NRB 15575:2013, e dentre outras. A Figura 1 retrata o sistema de parede de concreto moldadas no local através de uma obra vertical integrada ao programa MCMV. 
Figura 1 - Exemplo de obra construída no sistema de paredes de concreto moldadas no local

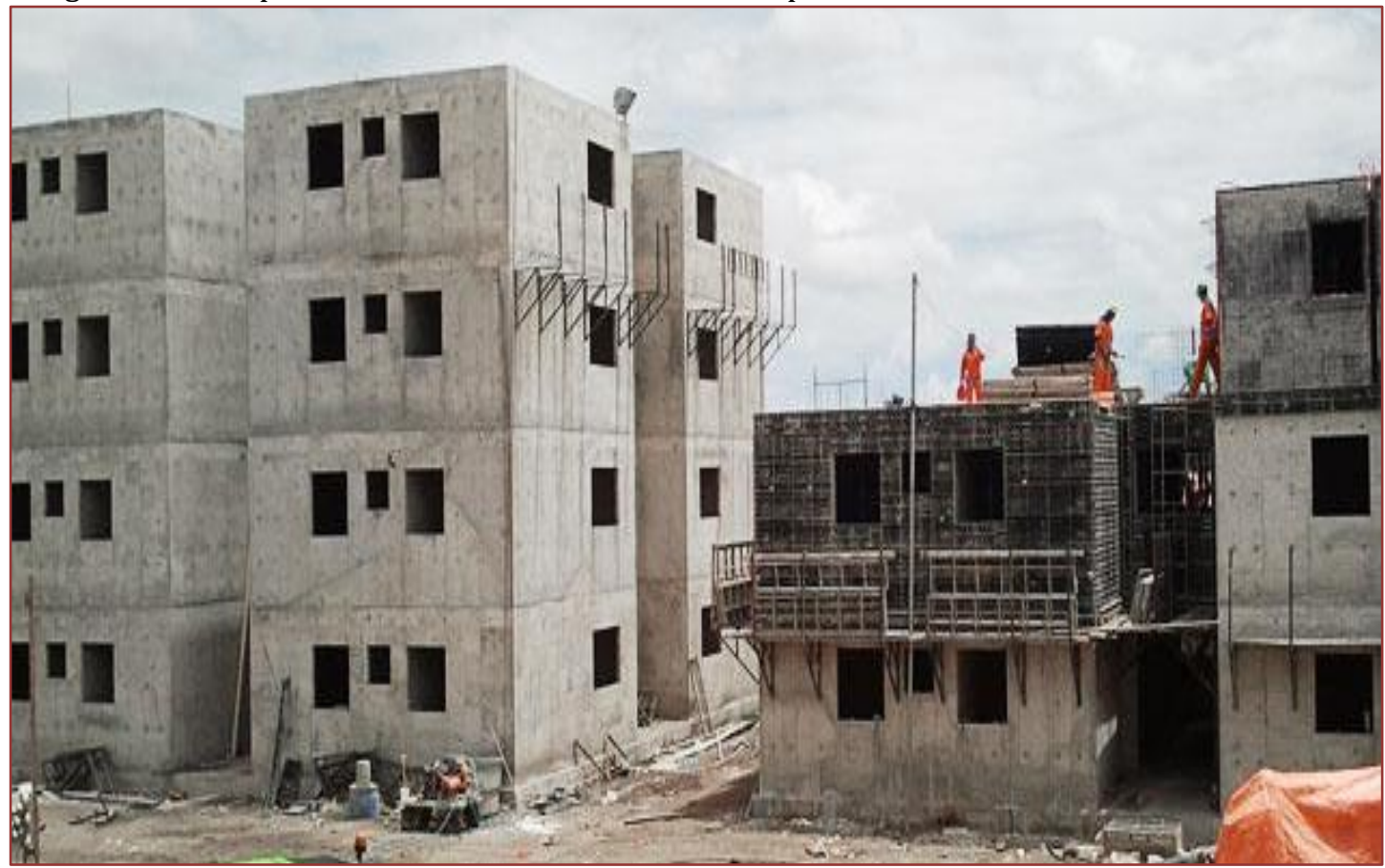

Fonte: Tecnosil (2019)

\subsubsection{SISTEMA DE FÔRMAS}

A ABCP (2008) externa que as fôrmas utilizadas na modelagem das paredes de concreto são estruturas provisórias capazes de resistir as solicitações de lançamento e adensamento do concreto, assegurando sua forma e estanqueidade até a sua remoção.

Maranhão (2000) declara que o uso de fôrmas não se resume a fixar o concreto, visto que elas são encarregadas pela preservação e aquisição dos aspectos e formas finais pretendidos, sendo a primeira responsável pelo acabamento das faces nas estruturas.

A norma NBR 16055 (2012), descreve que o sistema de fôrmas é composto por painéis, escoramento, cimbramentos, aprumadores e andaimes, incluindo seus apoios e as uniões entre os diversos elementos.

Para a escolha do tipo de fôrma devem ser levadas em conta as condições econômicas, facilidade no fornecimento, características do projeto arquitetônico, qualidade exigida no acabamento e o número de repetições impostas ao conjunto. 0 sistema parede de concreto exige uma mão de obra especializada para a montagem, o tipo de fôrma e a experiência dos montadores é fator determinante do ritmo e da qualidade. (SANTOS, 2011, apud FERNANDES, 2019).

Abbate (2003) orienta que em qualquer que seja o sistema de formas utilizado, a aplicação do desmoldante é essencial, de modo a garantir a possível reutilização das fôrmas, a facilitar desforma e impedir a aderência entre ambos.

A escolha do desmoldante a ser utilizado deve ser escolhido cuidadosamente. A norma NBR 16055 (2012) aponta os requisitos que o produto deve atender:

- Garantir que o concreto não tenha aderência à fôrma;

- Não deixar resíduos e nem ser de difícil remoção;

- Não alterar as características físicas e químicas do concreto;

- Não degrada a superfície das fôrmas.

A Associação Brasileira das Empresas de Serviços em Concreto (ABESC, 2012), aponta que alguns aspectos devem ser considerados na escolha adequada do tipo de fôrma, dado que é o fator determinante para a potencialização da produtividade e da economia. Os aspectos que devem ser considerados para definir o tipo de fôrma são: 
- A produtividade da mão de obra na operacionalização do conjunto;

- 0 peso por $\mathrm{m}^{2}$ dos painéis, visto que painéis muito pesados dificultam a movimentação e transporte dentro da obra;

- A durabilidade das chapas e número de reutilização;

- A modulação dos painéis, que interfere diretamente na economia do empreendimento;

- A adequação quanto a fixação de embutidos (hidráulica, elétrica), na hipótese de erros nessa fase, atrasará o andamento da obra, já que as etapas desse método construtivo são simultâneas;

- A análise econômica e comercialização (locação venda e leasing), certos materiais de fôrmas são caros, ou de difícil localização para compra ou aluguel no Brasil, por isso esse fato deve ser levado em conta na hora da escolha da fôrma;

O suporte técnico do vendedor (capacidade instalada, área de cobertura, agilidade de atendimento, oferta de treinamento e assistência técnica), devido a necessidade de assistência em várias etapas de montagem e desmontagem das fôrmas.

\subsubsection{MÃO DE OBRA}

Uma das características básicas fundamentais na construção de paredes de concreto com qualidade é a mão de obra. A produtividade da mão de obra é potencializada pelo treinamento direcionado ao sistema de paredes no local (TECNOSIL, 2019). Na Figura 13 é exemplificado o resultado de treinamentos, ilustrando colaboradores executando corretamente a limpeza de painéis de fôrma metálica.

A Comunidade da Construção (2012), reforça que é preciso definir adequadamente as equipes tendo como base a produção e o grau de dificuldade da obra. Não deixando esquecer os treinamentos específicos e periódicos para todos das esquipes, estabelecendo metas e tarefas, no intuito de motivar a produtividade.

Quanto aos treinamentos, a ABCP (2007), diz que antes de começar a execução do serviço, é necessário todo colaborador passar por um curso de montagem das fôrmas, onde são apresentadas as etapas executivas detalhadas e projetos executivos a fim de evitar improvisos em campo.

Em virtude do caráter de industrialização apresentado pelas paredes de concreto moldadas no local, possibilita-se que a sua competitividade seja potencializada através da produtividade da mão-de-obra. Assim, as principais variáveis que afetam a produtividade da mão-de-obra são: a tipologia da obra, o projeto de fôrmas, o projeto das armaduras, instalações, processos e treinamento aplicado. (Comunidade da Construção, 2012)

Arêas (2013) aborda que é interessante as equipes sejam formadas com a presença de pelo menos um líder, membro que lidera naturalmente a equipe, organiza e motiva os parceiros.

\subsubsection{CICLO "ZIG-ZAG" OU "CICLO DE UM"}

Neves (2017), esclarece que o ciclo se inicia com a concretagem de um lado do radier, e enquanto o concreto adquire a resistência, é executada a montagem das fôrmas do outro lado, com isso, após a segunda concretagem, o concreto da primeira concretagem já curou tempo suficiente para o início de mais um pavimento. A Figura 14 mostra o ciclo de concretagem e retirada dos escoramentos no sistema de paredes de concreto de uma empresa especifica.

\section{METODOLOGIA}

A pesquisa é exploratória, onde se deu origem com pesquisas em revistas de engenharia, normas técnicas, artigos técnicos, além de outros trabalhos de final de curso com tema similar. Tendo como base as pesquisas bibliográficas, nessa capitulo será apresentado um estudo de caso, a fim de demonstrar os cuidados que devem ser tomados no processo executivo. Segundo Richardson (1999) "os resultados do trabalho permitirão rever o plano de pesquisa para a realização de um estudo mais aprofundado sobre o tema". 0 trabalho é dissertado conforme apresentação das etapas na Figura 2 e descritas a seguir: 
Figura 2 - Etapas do Trabalho

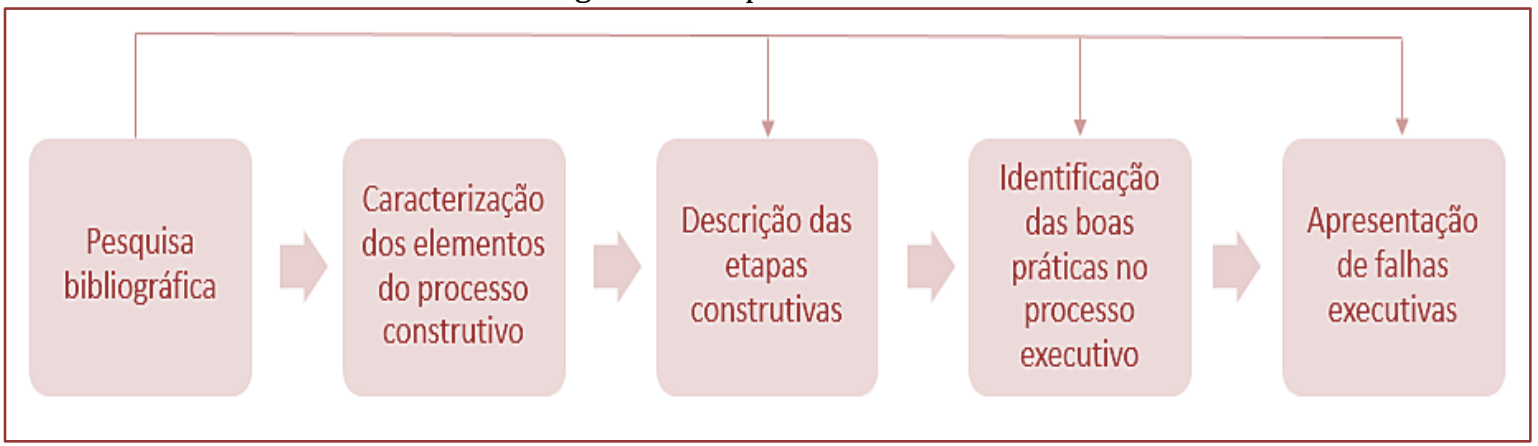

Fonte: Autoria Própria

Segundo Yin (2005), a entrevista é uma das fontes de informação mais importantes e essenciais, nos estudos de caso. Meirinhos e Osório afirmam que entrevista é considerada uma interação verbal entre, pelo menos, duas pessoas: o entrevistado, que fornece respostas, e o entrevistador, que solicita informação para, a partir de uma sistematização e interpretação adequada, extrair conclusões sobre o estudo em causa. Flick (2004), acredita que o interesse está associado com a expectativa de que é mais provável que os sujeitos entrevistados expressem os seus pontos de vista numa situação de entrevista desenhada de forma relativamente aberta do que numa entrevista estandardizada ou num questionário. A entrevista realizada formou-se pelas seguintes perguntas:

- Quais as maiores dificuldades no processo de execução de paredes de concreto moldadas no local?

- Quais os erros mais comuns identificados nas etapas executivas?

- Quais as falhas executivas e patologias encontradas?

\subsection{ESTUDO DE CASO}

Composição do passo a passo na descrição do processo executivo do sistema construtivo de paredes de concreto moldadas no local. Para examinar a prática do processo construtivo de paredes de concreto moldadas no local foi descrito um passo a passo identificando um conjunto de condutas, itens e tarefas que precisam ser lembradas e seguidas atentamente. É apresentado um passo a passo de maneira global descrevendo a execução de um modo geral, e uma apresentação de falhas quando não são seguidas as boas práticas durante o processo. As circunstâncias apontadas serão: planejamento, segurança, execução nas etapas do sistema.

A obra a ser estudada está localizada na Avenida das Torres, Bairro Lago Azul, zona urbana norte da cidade de Manaus, situada entre as coordenadas -2.969274 / -60.000561. 0 empreendimento é formado por 20 blocos, sendo cada bloco composto por 5 pavimentos e 40 unidades habitacionais, totalizando 800 moradias.

\section{RESULTADOS E DISCUSSÕES}

\subsection{DESCRIÇÃO DAS ETAPAS DO PROCESSO CONSTRUTIVO}

A descrição será desenvolvida apresentando detalhadamente o processo junto as boas práticas na sequência executiva de paredes de concreto, utilizando formas metálicas a fim manifestar patologias quando o processo não é realizado de maneira padronizada. A sequência construtiva se repete após a execução das paredes de cada pavimento, tornando-se um ciclo produtivo (ciclo zig-zag ou ciclo de um). Depois da primeira concretagem, o ciclo é reiniciado, porém, recomeça na atividade de marcação de paredes e em seguida continua a sequência executiva até ao acabamento. 


\subsubsection{FUNDAÇÃO TIPO RADIER}

A partir da definição do projeto, é iniciada a construção da fundação. Para o desempenho e qualidade algumas etapas as seguintes devem ser executadas atentamente:

- É necessário que o responsável pela topografia marque os pontos do terreno que devem ser nivelados para que atinja a cota de projeto;

- Após executar o nivelamento do terreno, é conferido a formação com equipamento a laser;

- A implantação da fôrma, em material metálico, delimitará o contorno do radier, é fundamental que na conclusão seja conferido o nivelamento da fôrma com equipamento a laser;

- Em seguida é introduzido uma mistura de areia, cimento e seixo, formando uma camada protetora e de nivelamento, com finalidade de evitar o contato da armação com o solo;

- São vedadas todas as tubulações de hidráulica e elétrica, para evitar entupimento com concreto;

- São posicionados e fixados arranques de parede com pedaços de tela soldada, no local designado em projeto, além de reforçar com barras de aço, evitando o desalinhamento no momento da concretagem;

- Acompanhar a concretagem, verificando constantemente o nivelamento final da fundação utilizando equipamento a laser.

\subsubsection{MARCAÇÃO DAS PAREDES}

Após o nivelamento da base (fundação ou laje) é necessário realizar a marcação, que é considera a primeira atividade no processo executivo das paredes de concreto, sendo classificada uma atividade fácil, porém exige atenção extrema na execução. Dá-se início com a marcação utilizando linha de pedreiro, tinta e esquadro. Para a separação e alocação dos painéis de fôrma, são instalados nas extremidades das paredes ou em locais estratégicos, no chão, espaçadores "GAP 100" (Figura 3), com o uso de pistolas chumbadoras.

Figura 3 - Linhas de marcação de parede e espaçador GAP

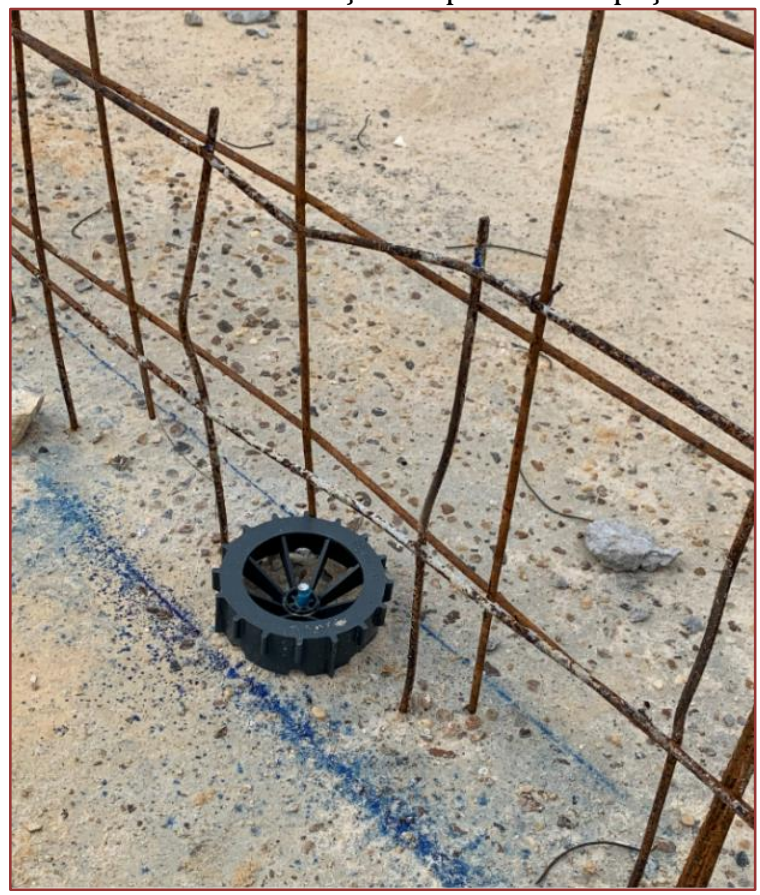

Fonte: Acervo da obra 


\subsubsection{ALOCAÇÃO DAS ARMADURAS E REFORÇOS}

Dependendo do projeto estrutural, o engenheiro tem a opção de escolher a configuração mais produtiva para utilizar as telas soldadas, podendo ser usadas inteiras e cortá-las do tamanho especificado em projeto no momento da instalação, ou deixar arrumado kits com tamanhos determinados em projeto, onde terá maior aproveitamento do produto evitando desperdício de material.

A armação é um elemento imprescindível no sistema, garantindo absorção dos esforços e distribuição deles pelo ambiente. Tendo como base essa informação, a execução e alocação deve ser realizada com prudência, alinhando as armações com as telas de arranque que ficam chumbadas na base. Em seguida são instalados os reforços, sendo alocadas e fixadas barras de aço em pontos especificados no projeto como vãos de portas, janelas e paredes longas. Esse serviço é finalizado com a colocação de espaçadores.

As armações e reforços das lajes, são alocadas após a montagem completa das fôrmas, é de suma importância a implantação dos espaçadores garantindo o cobrimento de concreto desejado. Visando a necessidade de colaboradores circularem sobre a laje para completar os demais serviços como elétrica e hidráulica, os espaçadores são amarrados as telas por arame recozido evitando que eles saiam de posição.

\subsubsection{ALOCAÇÃO DAS INSTALAÇÕES PREDIAIS}

Nas instalações elétrica, todas as caixas de passagem, quadros elétricos (QDC) são confeccionados em kits (materiais elétricos amarrados por arame recozido em pedaços tela) na central elétrica. Todos os materiais, para que não saiam do prumo, não entrem na parede e não ocorra entupimento na concretagem, devem ser embutidos nas paredes, por isso são bem fixados nas telas soldadas. Para auxiliar o escoamento do concreto entre os eletrodutos e demais componentes elétricos é utilizado espaçadores garantindo a cobertura adequado. Quanto as instalações hidrossanitária e hidráulica, são alocados nas fôrmas conectores em PVC e posicionadores provocando maior alinhamento.

\subsubsection{MONTAGEM DA FÔRMA}

Antes da primeira montagem das fôrmas é essencial que seja conferida junto aos projetos de detalhamento da montagem das fôrmas, todas as peças necessárias para a execução, desde as maiores até as menores. Caso esteja faltando alguma peça deve-se entrar em contato imediatamente com o fornecedor, ou com o setor responsável da empresa. Isso evitará improvisos e problemas futuros. A montagem da fôrma é executada pela seguinte sequência:

- Inicia-se aplicando o desmoldante na face e nas laterais das peças que ficarão em contato com o concreto.

- As primeiras alocações dos painéis devem ser os cantos de 90ํㅡ com painéis internos das paredes;

- Posteriormente os painéis externos;

- Em seguida os painéis "canto laje";

- Finaliza-se alocando os painéis da laje.

\subsubsection{TRAVAMENTOS E ESCORAMENTO}

Referente ao travamento, é uma tarefa que acompanha simultaneamente a montagem da fôrma. Os travamentos são feitos através de pinos, cunhas e faquetas fixados nos lugares apropriado. Os montadores devem ter atenção ao escolher o tipo de pino, cunha e faqueta para que não haja folga no travamento, mesmo que os painéis sejam similares, visto que existem diversos fabricantes de fôrmas metálica, onde cada uma possui características especificas e suas peças são exclusivas.

As faquetas são hastes de metal que realizam o travamento entre as fôrmas de parede interna e externa, garantindo rigidez na concretagem. Para o uso da faqueta deve-se colocar uma proteção (luva ou camisinha), além disso é indicado que seja aplicado desmoldante na peça facilitando a remoção após a desforma. Quanto ao escoramento, as escoras devem ser instaladas conforme especificação do projeto garantindo o devido nivelamento da laje superior. A Figura 4 apresenta escoras de travamento da laje. 
Figura 4 - Escoramento da laje superior

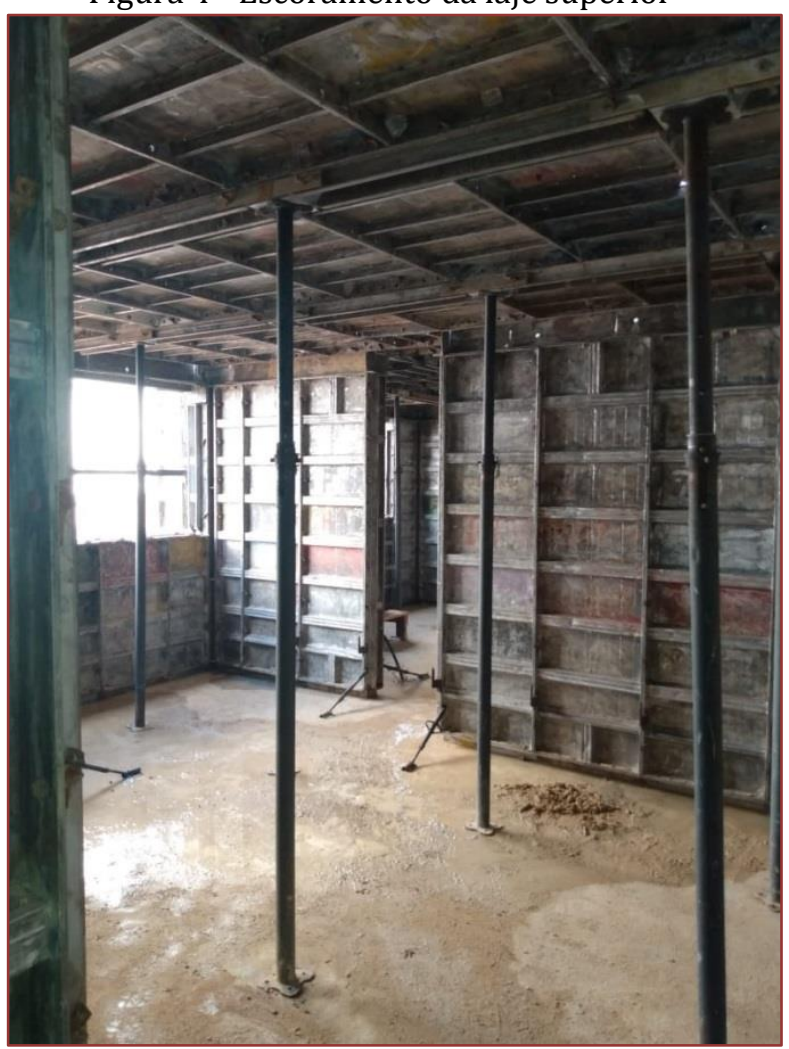

Fonte: Acervo da obra

\subsubsection{CONCRETAGEM}

0 procedimento da concretagem, começa a partir do momento que o caminhão betoneira chega no canteiro de obra. 0 concreto de cada caminhão deve passar pelo controle tecnológico, realizando o "slump Test" a fim de verificar a consistência do concreto, e a compatibilidade com a especificação do projeto. Nessa etapa alguns corpos de prova são separados, onde serão submetidos a testes de compressão no dia seguinte e os demais corpos de prova serão enviados ao laboratório para determinar a resistência do concreto com 28 dias.

Após o ensaio do slump test, o caminhão betoneira é posicionado no local mais próximo da área de concretagem e coloca o mangote a uma altura apropriada para efetuar o lançamento do concreto. A realização dessa etapa deve ser feita com atenção, iniciando pelos cantos, lançando o concreto na laje próximo a abertura das paredes deixando-o escorrer de forma homogênea preenchendo os espaços vazios e evitando a pressão nos painéis de parede.

Para adensar o concreto da forma correta, ao ser lançado é acompanhado de vibração sem deixar que o aparelho toque nas fôrmas. Em conjunto com a vibração é aplicado batidas nos painéis com martelo de borracha auxiliando no deslocamento do concreto para pontos de difícil acesso.

A desforma é realizada com o auxílio de marretas para a retirada das cunhas, pinos e demais travamentos, menos as escoras. É de extrema importância a permanência das escoras respeitando o tempo determinando em projeto a fim de evitar que a laje sofra esforços pelo peso próprio. A Figura 5 mostra as escoras com cabeçotes (peças complementares dos painéis da laje), após a desforma ainda posicionados no local designado a eles. 
Figura 5 - escoramento após desforma dos painéis

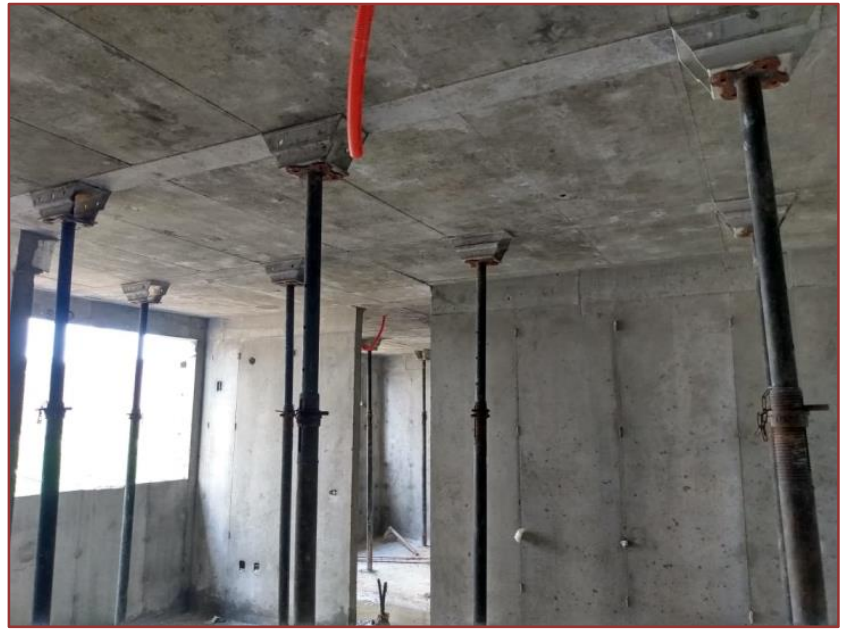

Fonte: Acervo da obra

A sequência da retirada dos painéis é a inversa do processo de montagem. Retira-se os painéis da laje, "canto laje", paredes externas e internas junto com os cantos de 90o respectivamente. Além disso é feito a limpeza das formas. Em todo processo de desforma tendo em vista a praticidade, quanto mais cedo for realizada a limpeza, menos endurecido estará o concreto. A limpeza das fôrmas é realizada com o intuito de não acumular resíduos entre os painéis, evitando dificuldades na montagem e travamento.

Para finalizar o processo executivo das paredes de concreto moldadas no local é necessário realizar o acabamento fazendo o estucamento e regularização da estrutura, preenchendo os buracos e imperfeições das paredes com argamassa ou dependendo da gravidade, com graute. Feito isso, a sequência do acabamento externo é feita apenas com um selador acrílico e textura rolada, já o interno é passado um selador acrílico, depois uma massa corrida e pôr fim a pintura a base d'água.

\subsubsection{FALHAS NA EXECUÇÃO}

A falta de materiais de extrema relevância, por exemplo esquadros de travamento, painéis da fôrma, alinhadores horizontais, consoles do andaime para a segurança; em virtude que, normalmente, todos os materiais referentes a fôrma metálica que são utilizadas no estado no Amazonas, pela empresa em questão, são estocadas em outros estados. Antes de iniciar qualquer obra é solicitado o encaminhamento de peças complementares afim de acrescentar a fôrma que vinha sendo utilizada, ou das peças por completo caso seja utilizada uma nova fôrma.

A identificação da mão de obra desqualificada, em razão de que alguns colaboradores, mesmo possuindo todos os treinamentos necessários para realizar as atividades designadas a eles. Não seguindo as boas práticas ou não dando a devida importância. Diante disso, quando se identifica o servidor, é efetuado o desligamento imediato, visto que o mesmo não se enquadra nas especificações da empresa.

Referente aos erros mais comuns, foram apontados a falta de utilização de espaçadores em lugares específicos de difícil acesso ao concreto no momento da concretagem; o descuido de alguns colaboradores ao transitarem pela laje deslocando os espaçadores da laje, tirando-os da posição adequada para que seja proporcionado o cobrimento apropriado; o lançamento do concreto, realizado por terceirizados, sendo disparado momentaneamente direto nas aberturas das paredes e a uma altura elevada, não recomendada pelo setor da qualidade; a vibração do concreto, também realizada por terceirizados, sendo efetuada temporariamente, inserindo em excesso o aparelho entre os painéis das paredes.

Pertinente as falhas encontradas, após a desforma, o engenheiro responsável conseguiu identificar as principais encontradas. A seguir, as anomalias serão apresentadas de maneira elaborada, conforme mostra a Tabela 1, seguindo a sequência da descrição mencionada pelo engenheiro.

Vale ressaltar que as figuras que serão incorporadas nesta etapa do trabalho, derivam de revistas de engenharia, artigos técnicos, além de outros trabalhos de final de curso com tema similar, visto que a visita técnica na obra estudada foi indeferida pela diretoria da empresa, a fim de preservar a saúde dos funcionários e do visitante evitando qualquer hipótese de contaminação pelo vírus Covid-19. 
Tabela 1 - Anomalias Identificadas

\begin{tabular}{|c|c|c|}
\hline Ordem & Patologia & Causas \\
\hline $1^{\mathrm{o}}$ & Vazios de concretagem & Erros relacionados ao concreto, erro humano \\
\hline $2^{\circ}$ & Segregação do Concreto & Erro humano \\
\hline 3 o & Fissuras & $\begin{array}{l}\text { Problemas físicos e químicos do concreto, possível } \\
\text { erro humano }\end{array}$ \\
\hline $4 \div$ & Porosidade nas Paredes & Erro humano \\
\hline 50 & Armadura Aparente & Erro humano \\
\hline $6^{0}$ & $\begin{array}{l}\text { Entupimento e Desalinhamento de Caixas } \\
\text { e QDCs }\end{array}$ & Erro humano \\
\hline $7^{\circ} \underline{0}$ & $\begin{array}{l}\text { Falha de Cobrimento e Eletrodutos } \\
\text { Aparentes }\end{array}$ & Erro humano \\
\hline $8^{\circ}$ & Abertura dos Painéis & Erro humano \\
\hline
\end{tabular}

onte: Autoria própria

\section{A) VAZIOS DE CONCRETAGEM (BICHEIRAS)}

Os casos constatados de vazios de concretagem, são provenientes de problemas relacionados ao concreto, por exemplo o traço, a trabalhabilidade e a forma de lançamento. Scheifer (2016), atesta que as principais causas do surgimento das bicheiras são a má vedação das fôrmas, problemas no lançamento do concreto, traço de concreto incorreto para armaduras densas e, principalmente, mau adensamento do concreto no estado fresco. A Figura 6 exemplifica um cenário onde ocorreu esse tipo de falha.

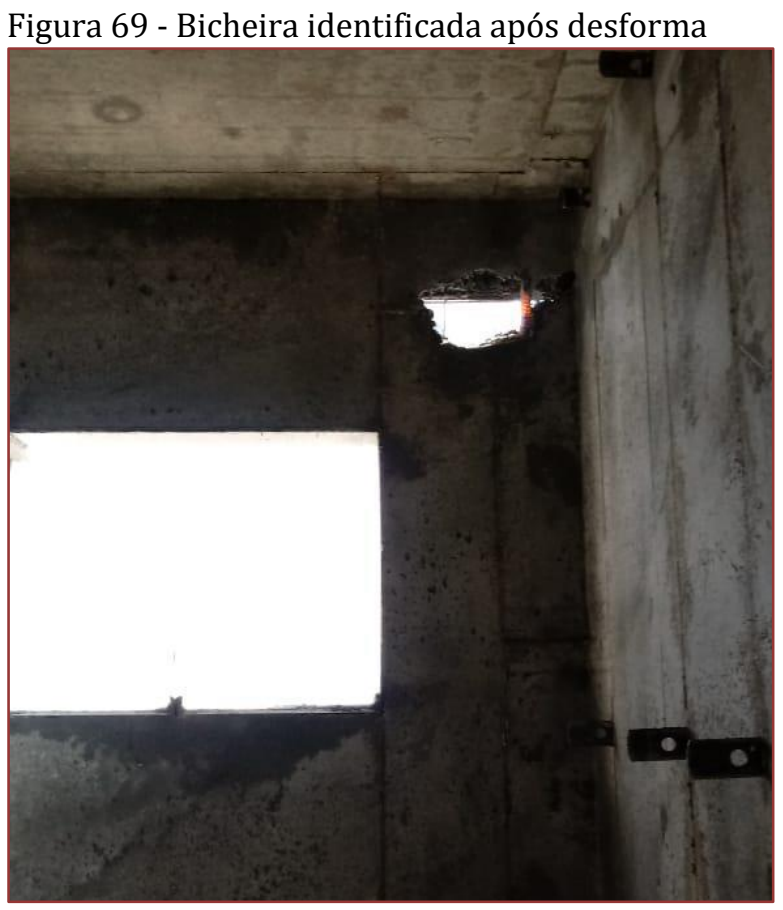

Fonte: Fernandes, 2019

A quantidade de casos identificados na obra foi razoável. Os problemas foram apresentados nos primeiros pavimentos a serem concretados, devido à falta de trabalhabilidade do concreto, paralelo à falta de instruções dos operários terceirizados referente a utilização do aparelho vibrador de concreto, durante a concretagem. Nos casos encontrados, o reparo foi feito com a aplicação de graute na área afetada, mesmo sendo pequenas áreas.

\section{B) SEGREGAÇÃO DO CONCRETO}

Após a desforma foi detectado falhas de segregação dos materiais, que compõe o concreto utilizado, com exposição dos agregados e separação dos materiais do concreto, como mostra modelo na Figura 7. 
Figura 7 - Segregação do concreto Fonte: Fernandes, 2019

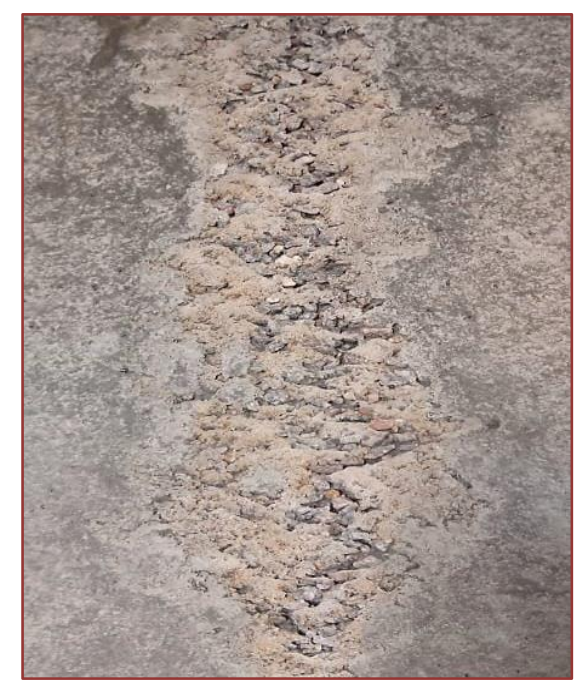

Foi anunciado que a possível causa da ocorrência dessa patologia tenha sido a redosagem de água no concreto no canteiro de obra. Fernandes (2019) diz que a utilização excessiva de aditivos e a redosagem de água do concreto são fatores que influenciam à segregação. 0 reparo adotado, para as falhas, foi a utilização de uma camada de argamassa cimentícia.

\section{C) FISSURAS}

Foi constatado que o surgimento das fissuras, nas superfícies das paredes, deu-se em média de 20 dias após a concretagem dos pavimentos. Todas as fissuras encontradas no decorrer da execução do empreendimento foram rastreadas pelo setor da qualidade. 0 acompanhamento foi realizado com o auxílio de um fissurômetro para determinar a espessura inicial de quando foi identificada até a data posterior estipulada pelo setor responsável. 0 acompanhamento teve finalidade de supervisionar a fissura e conferir se houve estabilidade ou progresso na abertura da mesma. A Figura 8 exibe a utilização do fissurômetro.

Figura 8 - Utilização do fissurômetro Fonte: Fernandes, 2019

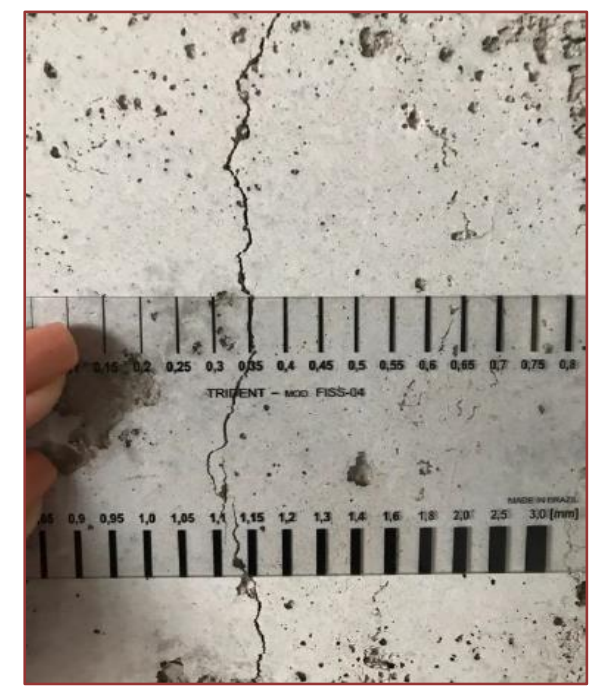


As causas apontadas pelo engenheiro responsável para essa anomalia foram as retrações térmicas e hidráulica, além da desforma com muito impacto. Segundo a ABESC (2007), as fissuras que ocorrem antes do endurecimento do concreto são o resultado de assentamentos diferenciais dentro de sua massa (sedimentação), ou da retração da superfície causada pela rápida perda de água e resfriamento enquanto o concreto ainda está plástico. Outra causa pode ser a movimentação da peça concretada (fôrmas ou superfície de contato).

A ABESC (2007), completa "As fissuras que ocorrem no concreto após o endurecimento podem ser resultado da retração hidráulica, acabamento, concentração de esforços, projeto estrutural ou acidente”. 0 reparo realizado em fissuras das paredes externas e de áreas molhadas se deram pela utilização de selante para preenchimento. Após a cura do selante indicada pelo fabricante, foi efetuada a implantação de uma tela estruturante de poliéster em toda a extensão da fissura, fixando-a com uma argamassa cimentícia impermeabilizante. Nas paredes internas, a correção das falhas foi indicada para a fase de acabamento, sendo removidas com massa cimentícia branca utilizada para o emassamento.

\section{D) POROSIDADE NAS PAREDES DE CONCRETO}

Outro problema recorrente, foi aparições de pequenas deformações no concreto criando uma pequena porosidade superficial (Figura 9). Foi percebido que esse problema aconteceu pela existência de bolhas de ar que ficaram presas entre o concreto e a fôrma. A atitude tomada para que não voltasse a ocorrer essa falha, foi disponibilizar um colaborador para efetuar pequenos golpes com marreta de borracha nos painéis da fôrma durante a concretagem.

Figura 910 - Porosidade em parede de concreto

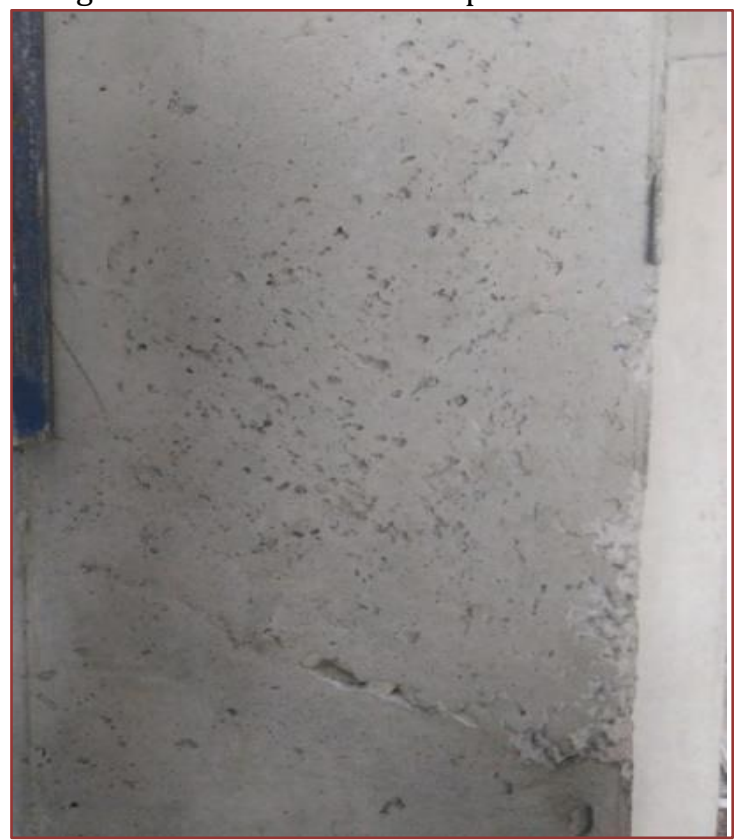

Fonte: Farias, 2019

\section{E) ARMADURA APARENTE}

Nas primeiras lajes foram detectadas partes das armaduras que ficaram expostas conforme modelo apresentado na Figura 10. Esse problema foi visto apenas em duas lajes da obra. Durante a execução foi possível verificar que todas as lajes possuíam espaçadores nas telas. Porém, antes e durante a concretagem, foi percebido que os operários ao transitarem nos locais onde haviam espaçadores, deslocavam o material e as telas ficavam em contato com a fôrma da laje. 
Figura 1011 - Armadura da Laje exposta

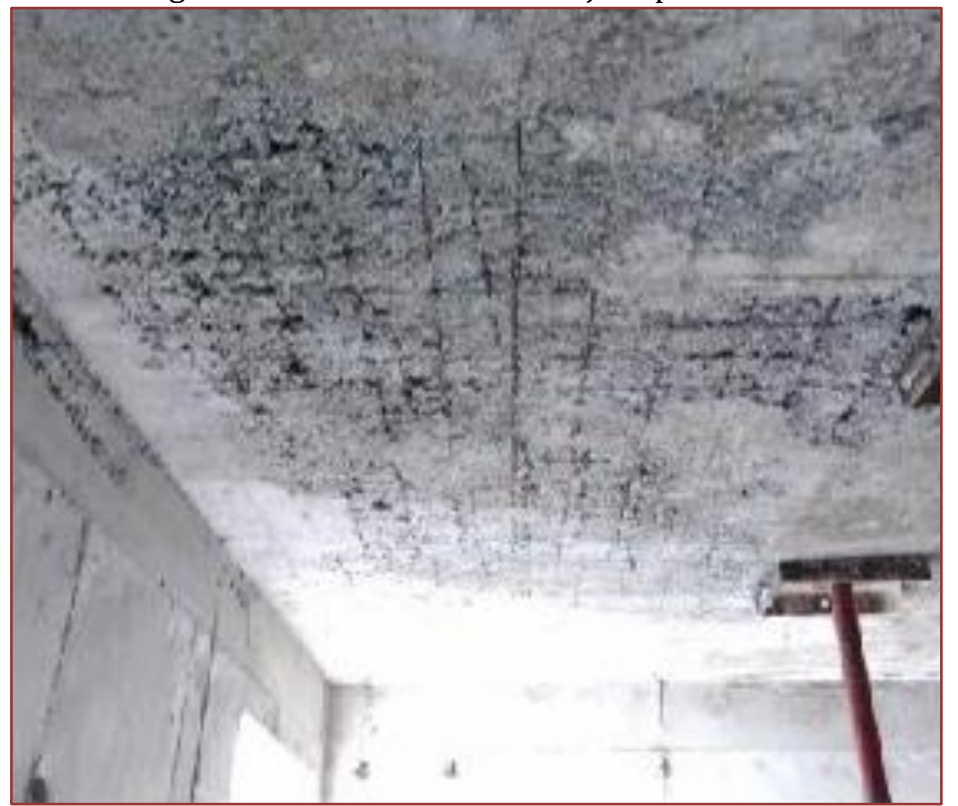

Fonte: Sampaio, 2016

A correção imediata foi passar as instruções aos colaboradores, tomando o devido cuidado ao transitarem sobre a laje para evitar o deslocamento dos espaçadores e para reforçar a funcionalidade do material, solicitando aos responsáveis pela implantação dos espaçadores que eles fossem amarrados com arame recozido garantido o cobrimento adequado. Nas lajes que apresentaram esse problema foi aplicado uma camada de argamassa cimentícia.

\section{F) ENTUPIMENTO E DESALINHAMENTO DE CAIXAS E QUADROS}

Os principais fatores apontados sendo os causadores dessas falhas foram os rompimentos dos eletrodutos e a má vedação das tampas das caixas de passagem. Referente ao desalinhamento foi identificado que devido a fixação equivocada, durante a concretagem as caixas de passagem foram movimentavas lateralmente ou sendo rotacionadas. A Figura 11 exibe uma caixa de passagem desalinhada.

Figura 1112 - Caixa de Passagem desalinhada

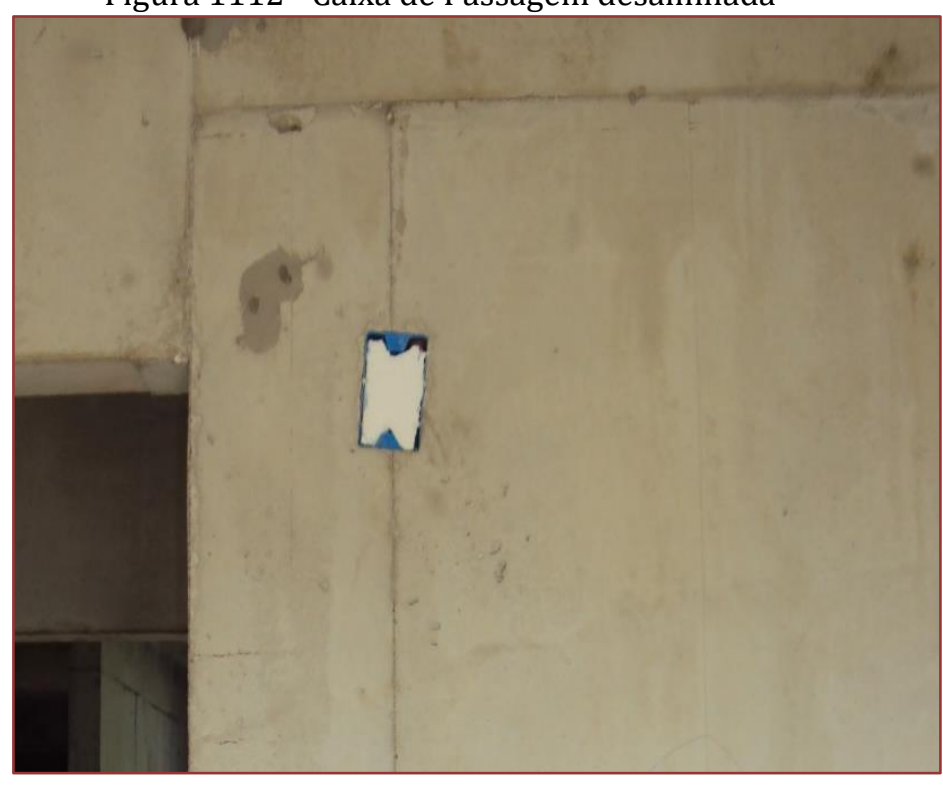

Fonte: Farias, 2019 
Farias (2019), alerta que caso a fixação dos componentes elétricos, na tela soldada, sejam mal executadas é provável que haja desalinhamento das caixas de passagem, dos quadros gerais de circuitos e até mesmo a exposição dos eletrodutos. 0 reparo realizado para o entupimento do sistema elétrico se deu em escariar a parede, retirar as partes entupidas, refazer a instalação e realizar o fechamento da parede com concreto dos próximos pavimentos ou graute.

\section{G) FALHA DE COBRIMENTO DO CONCRETO, ELETRODUTO APARENTE}

Melo (2019) afirma que as falhas de cobrimento dos eletrodutos são ocasionados pela má fixação dos eletrodutos, somado com a falta da utilização dos espaçadores próprios das caixas e QDCs. 0 engenheiro responsável confirmou que essas falhas ocorreram devido a fixação incorreta dos eletrodutos na tela metálica e alguns casos pela falta de espaçadores nas laterais dos eletrodutos.

A devida orientação foi dada aos colaboradores afim de evitar que esta anomalia continuasse ocorrendo, a indicação foi tomar a merecida atenção com a fixação dos eletrodutos e com a quantidade suficiente de espaçadores. 0 reparo para as paredes que apresentaram eletrodutos expostos foi escarear o concreto do entorno dos eletrodutos e forçá-los para dentro da parede. Por fim, realizava-se o fechamento com graute. A Figura 12 ilustra QDC, caixa de passagem 4X2 e eletrodutos expostos na parede de um dos apartamentos.

Figura 1213 - Eletroduto aparente

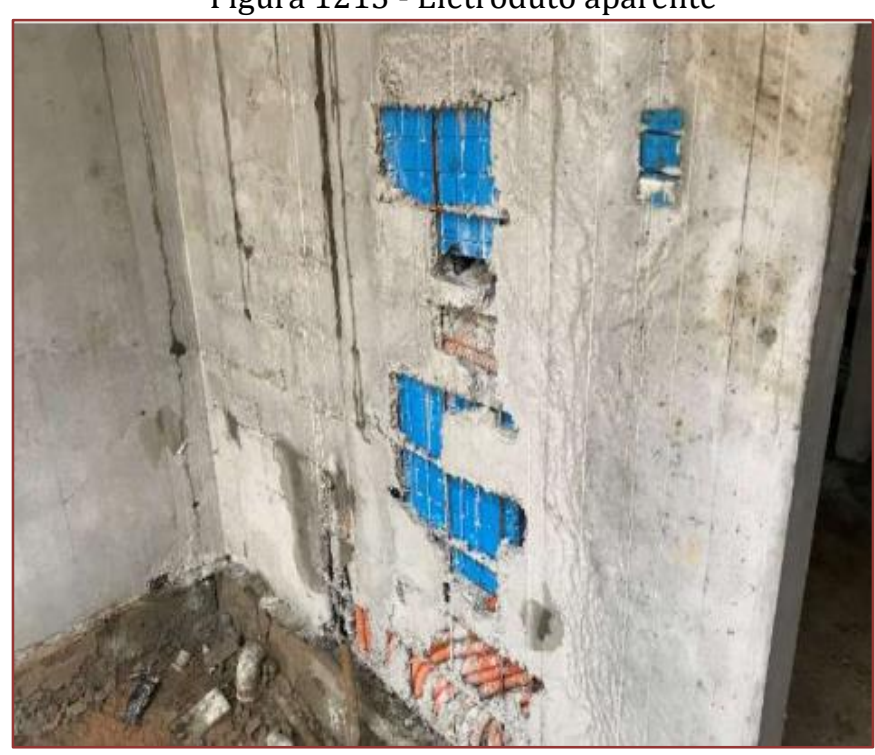

Fonte: Garcia, 2019

\section{H) ABERTURA DOS PAINÉIS}

Foi apontado que esse problema ocorreu pela abertura dos painéis, os quais foram travados erroneamente, e em outro caso foi utilizado de forma incorreta o aparelho vibrador de concreto no momento da concretagem, sendo inserido excessivamente dentro da forma promovendo folga nos travamentos. A abertura dos painéis proporciona uma grande perca de concreto, conforme exemplificação na Figura 13, causando grande aumento da espessura da parede. Após a retirada das placas foi necessário realizar uma operação de apicoamento da superfície e uma correção com argamassa posteriormente. 
Figura 13 - Desperdício de concreto causado pela abertura dos painéis

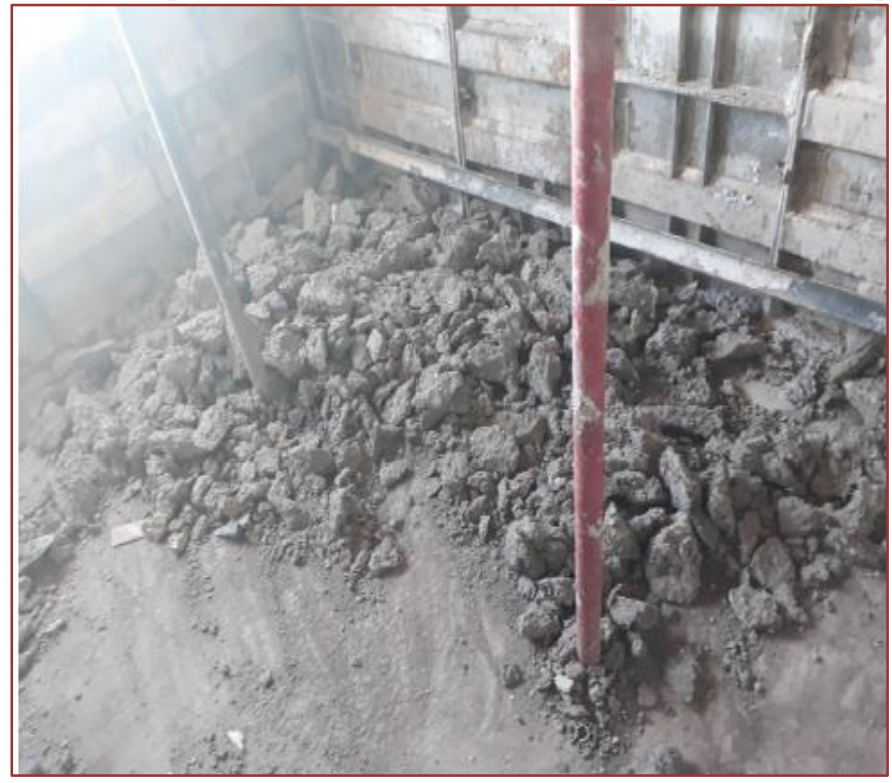

Fonte: Melo, 2019

Após a exposição das falhas e anomalias identificadas durante a execução do empreendimento, o engenheiro responsável estipulou uma média de incidência referente a cada caso, por bloco. A Figura 14 apresenta um gráfico onde é exposto a frequência das ocorrências das patologias.

Figura 14 - Incidência de Anomalias

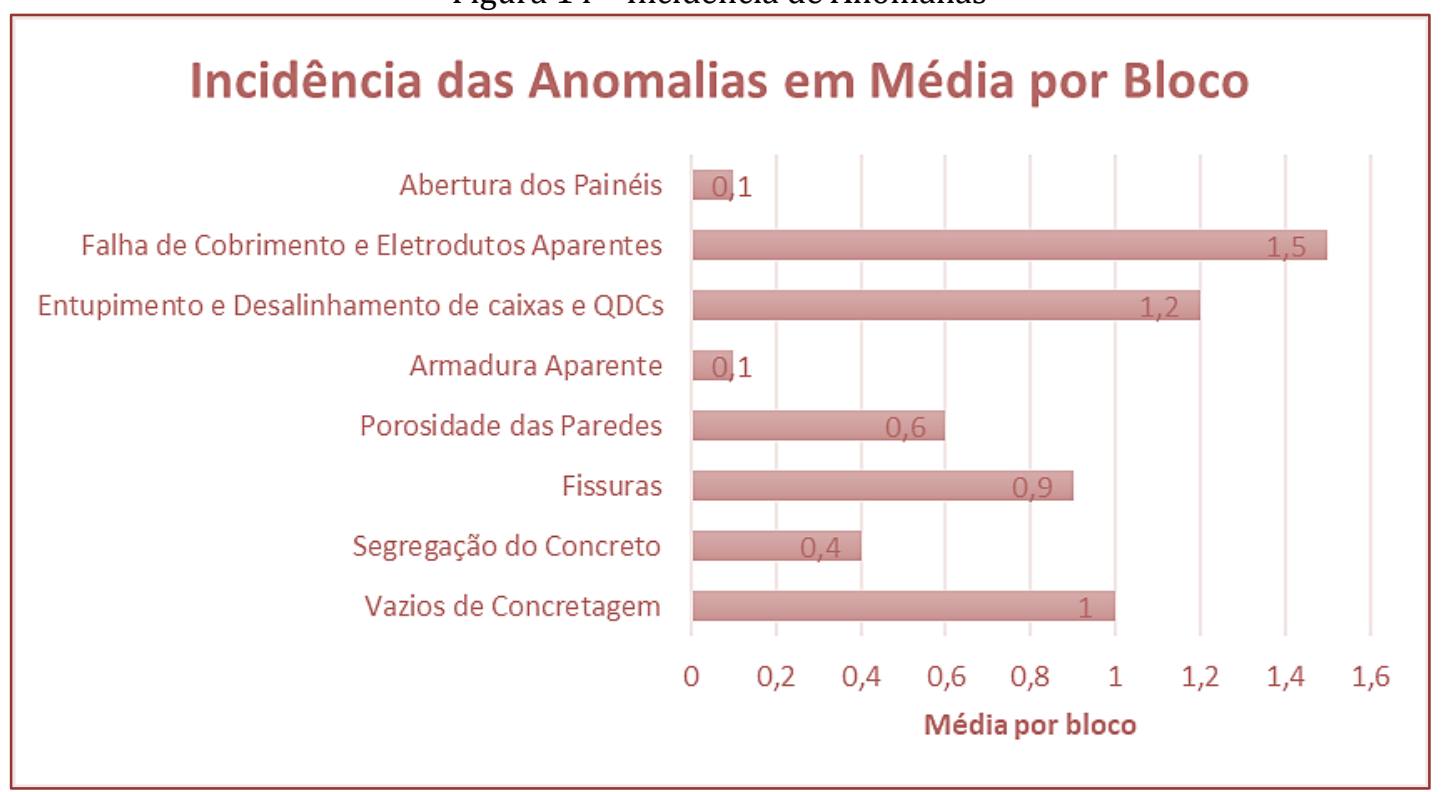

Fonte: Autoria Própria

O cálculo realizado para chegar neste resultado partiu de uma quantidade geral de ocorrências no total das concretagens (100 concretagens), conseguindo assim obter a média integral dos acontecimentos. A partir desses dados, foi realizada a média de incidência por bloco, multiplicando a média integral por 5 (quantidade de concretagens por bloco).

Dessa forma, fazendo uma breve analogia da tabela 04 com a figura 50, pode-se observar que a maioria das anomalias são provocadas por erros humanos, ou seja, é comum, em obras do sistema de paredes de concreto, que o colaborador execute suas atividades com falta de comprometimento, com falta de atenção, além de existir, em alguns casos, o despreparo e falta de conhecimento de certos funcionários efetivados 
da empresa ou terceirizados, que não tiveram a orientação adequada pelo setor da qualidade em forma de treinamentos.

\section{CONSIDERAÇÕES FINAIS}

O custo de implantação do sistema de paredes de concreto é alto, erros de planejamento de obra, desconhecimento das etapas construtivas e o dessaber do uso dos materiais podem, facilmente, acabar com um investimento caro em pouco tempo. 0 sucesso do sistema de paredes de concreto moldadas no local depende de um bom planejamento da sequência executiva, do uso de materiais de boa qualidade e de mão de obra qualificada

É importante ressaltar que os treinamentos com as equipes responsáveis pelas etapas construtivas do sistema são essências, além de clarificar a relevância da norma NBR 16.055:2012, criada especificamente para esse modelo de construção, a qual possibilita a uniformidade, segurança e qualidade na execução das paredes.

O processo construtivo se apresenta, claramente, de maneira industrializada. Este método é realizado em diversas etapas, sendo executado por equipes diferentes em suas respectivas atividades, de forma sucessiva, tendo um aumento da produtividade.

Tendo em vista que as construtoras conseguem diminuir o tempo de obra pela metade, diminuir efetivo de obra e desperdício de material, fica evidente a viabilidade econômica do sistema. A tecnologia da parede de concreto se destaca pela sua rápida execução e elaboração de projeto, ponto principal pelo atual crescimento de utilização. O desempenho da parede de concreto foi o impulso necessário para que as grandes e médias construtoras investissem nesse método de construção com menos pesar.

Precauções devem ser tomadas, pois normalmente, nas obras, diversos colaboradores que cumprem as metas de produção não seguem as instruções dos treinamentos e das normas específicas do processo executivo das paredes de concreto, com o intuito de finalizar suas responsabilidades dentro do horário previsto, antes da concretagem, sem a qualidade exigida. Posto isso, falhas executivas e patologias são identificadas antes, durante e após ao período de construção dos empreendimentos, proporcionando despesas em reparos às empresas.

Dessa maneira, o estudo foi importante para observar todas as possíveis falhas e suas possíveis causas, sendo ou erro humano, ou problema de propriedades físicas e químicas. O que ajudará, em obras futuras, os engenheiros responsáveis a identificar os contratempos no processo executivo das paredes de concreto moldadas no local, além de auxiliar na tomada de decisões rápidas e efetivas.

\section{REFERENCIAS}

[1] ABATTE, V. Desmoldante: um para cada tipo de fôrma. Revista Techne, n.70, jan 2003. Disponível em <htttp://techne17.pini.com.br/engenharia-civil/70/artigo286230-1.aspx >. Acesso em 12 maio. 2020.

[2] ANAUTE M. Programa Minha Casa Minha Vida e Parede de Concreto. Núcleo de Referência Paredes de Concreto, 2014. Disponível em: < http://nucleoparededeconcreto.com.br/destaque-interno/programa-minha-casaminha-vida-e-parede-de-concreto>. Acesso em: 10 maio 2020.

[3] ARÊAS, D. M. Descrição do Processo Construtivo de Parede de Concreto para Obra de Baixo Padrão. Trabalho de conclusão de curso (Bacharelado em engenharia civil) - Universidade Federal do Rio de Janeiro, 2013.

[4] ASSOCIAÇÃO BRASILEIRA DAS EMPRESAS DE SERVIÇOS DE CONCRETAGEM DO BRASIL. Manual do concreto dosado em central, 2007. Disponível em: <http://www.abesc.org.br/pdf/manual.pdf>. Acesso em: 10 maio de 2020 .

[5] ASSOCIAC̄̃̃O BRASILEIRA DE CIMENTO PORTLAND; ASSOCIAC̄̃̃O BRASILEIRA DAS EMPRESAS DE SERVIÇOS DE CONCRETAGEM, INSTITUTO BRASILEIRO DE TELAS SOLDADAS. Parede de concreto: coletânea de ativos 2007/2008. São Paulo, 2008.

[6] ASSOCIAÇÃO BRASILEIRA DE CIMENTO PORTLAND - ABCP. Manual Técnico para Implementação: Habitação 1.0: Bairro saudável, São Paulo, 1ํㅡㄹ. 2002.

[7] ASSOCIAÇÃO BRASILEIRA DE CIMENTO PORTLAND - ABCP. Parede de concreto: coletânea de ativos (20112013), 2013. Disponível em: <http://www.abcp.org.br/cms/wp-content/files_mf/Coletanea_PC2013.pdf>. Acesso em: 13 de março de 2020. 
[12] __ ABNT NBR 12655: Concreto de cimento Portland - Preparo, controle e recebimento - Procedimento. Rio de Janeiro, 2006.

[13] ___ _ _ ABNT NBR 14931: Execução de Estruturas de Concreto. Rio de Janeiro, 2004.

[14] ___ _ ABNT NBR 15575: Edificações Habitacionais - Desempenho. Rio de Janeiro, 2013.

[15] ___ ABNT NBR 15823-1: Concreto Auto Adensável. Parte 1 - Classificação, controle e recebimento no estado fresco. Rio de Janeiro, 2017.

[16] ___ _ ABNT NBR 16055: Parede de concreto moldada no local para a construção de edificações - Requisitos e Procedimentos. Rio de Janeiro, 2012.

[17] BEZERRA, F. Análise de Edifícios em Paredes de Concreto Moldadas In Loco. Trabalho de conclusão de curso (Bacharelado em engenharia civil) - Universidade Federal do Rio Grande do Norte, Natal, 2016.

[18] CAIXA. Cartilha Minha Casa Minha Vida. Disponível em: <http://www.ademi.org.br/docs/CartilhaCaixa.pdf>. Acesso em: 13 março 2020.

[19] CAZELl, P.; SOUZA, V. Sistema Construtivo Parede de Concreto Trabalho de conclusão de curso (Bacharelado em engenharia civil) - Faculdade Aldete Maria Alves, Iturama, 2018.

[20] CIMENTO ITAMBÉ, Sistemas Construtivos Inovadores Chegam ao Minha Casa, Minha Vida. 2013. Disponível em: < https://www.cimentoitambe.com.br/sistemas-de-construcao-inovadores-chegam-ao-minha-casa-minha-vida/> Acesso em: 30 abril 2020.

[21] COMUNIDADE DA CONSTRUÇÃO, Fôrmas de Alumínio EasySet. Disponível em: <http://www.comunidadedaconstrucao.com.br/produtos-servicos/4/formas-de-aluminio-easyset.html> Acesso em: 02 maio 2020.

[22] CONCRETO, Núcleo Parede de (Comp.). A importância das instalações elétricas-hidro sanitárias para o sistema parede de concreto. 2018. Disponível em: <http://nucleoparededeconcreto.com.br/cms/wpcontent/uploads/2018/04/Instalacoes-eletricas-hidrossanitarias.pdf>. Acesso em: 16 de março de 2020.

[23] ÉRICO, R.M. O que é Radier?. Disponível em: < http://portal4casa.com.br/o-que-e-radier/>. Acesso em: 05 maio 2020.

[24] FARIAS, B. Análise da execução de paredes de concreto em construções multifamiliares. Trabalho de conclusão de curso (Bacharelado em engenharia civil) - Universidade Federal de Santa Catarina, Florianópolis, 2019.

[25] FIGUEROLA, V. Vazios de concretagem. Revista Téchne, n 109, abril. 2006.

[26] FERNANDES, A.M.F. Estudo de caso sobre método construtivo de paredes de concreto moldadas "in loco" em casas populares. Trabalho de conclusão de curso (Bacharelado em engenharia civil) - Universidade Federal Rural do Semi- Árido, Mossoró/RN, 2019.

[27] FERTEL. Tela Soldada. Disponível em: <http://www.fertel.com.br/produtos/construcao-civil/telasoldada/>. Acesso em 10 de março de 2020.

[28] GARCIA, R. Causas, Diagnósticos e Tratativas de Patologias em Parede de Concreto: Estudos de Caso. Trabalho de conclusão de curso (Bacharelado em engenharia civil) - Centro Universitário de Anápolis, 2019.

[29] GOMES. J; ROCHA, M. Analise do Sistema Construtivo de Paredes de Concreto Moldada "in loco" - Um Estudo de Caso. Trabalho de conclusão de curso (Bacharelado em engenharia civil) - Centro Universitário de Anápolis, 2018.

[30] IBTS. Vantagens Técnicas. Disponível em: <http://www.ibts.org.br/telas_vantagens.asp>. Acesso em: 10 março 2020

[31] IZIDORO. L.S. Organização do Canteiro de Obras com a Implantação do Programa 5s. Trabalho de conclusão de curso (Bacharelado em engenharia civil) - Centro Universitário do Sul de Minas - UNIS, Varginha, 2014.

[32] JUNIOR, O.L.C. Estudo da modelagem de radier rígido em concreto armado na análise da interação soloestrutura. Trabalho de conclusão de curso (Bacharelado em engenharia civil) - Universidade Tecnológica Federal do Paraná, Pato Branco, 2016.

[33] LERMEN, S. Sistema Construtivo Parede de Concreto: Comparativo entre Pré-Fabricação e Moldagem In Loco. Trabalho de conclusão de curso (Bacharelado em Engenharia Civil) - Universidade Federal do Rio Grande do Sul, Porto Alegre, 2015. 
[34] MARANHÃO, George. 2000. Disponível em <http://web.set.eesc.usp.br/static/data/producao/2000ME_GeorgeMagalhaesMaranhao.pdf>. Acesso em 10 de maio. 2020 .

[35] MAQBLOCOS, Apoio para Cordoalha e Posicionador de Armadura. Disponível em: <https://www.maqblocos.com.br/detalhes-produto/65/apoio-para-cordoalha-e-posicionador-de-armadura-empisos-apr/>. Acesso em: 30 de abril 2020.

[36] MACÊDO, J. S. Um estudo sobre o sistema construtivo formado por paredes de concreto. Trabalho de conclusão de curso (Bacharelado em Engenharia Civil) - Universidade Federal da Paraíba, João Pessoa, 2016.

[37] MEIRINHOS, Manuel; OSÓRIO, António. O estudo de caso como estratégia de investigação em educação. Eduser - Revista de Educação. Dezembro. 2016

[38] MELO, V. Avaliação de Patologias Após Execução do Sistema Construtivo de Paredes de Concreto em Edifícios Destinados às Habitações Populares na Cidade de Uberlândia. Trabalho de conclusão de curso (Bacharelado em engenharia civil) - Universidade Federal de Uberlândia, Uberlândia, 2019.

[39] MIOTTO, A. Avaliação das Patologias no Sistema construtivo em Paredes de Concreto Moldadas no Local para Edifícios Residenciais. Trabalho de conclusão de curso (Bacharelado em Engenharia Civil) - Universidade Tecnológica Federal do Paraná, Curitiba, 2014.

[40] MISURELLI, H.; MASSUDA, C. Paredes de Concreto. Revista Téchne, n. 147, p. 74-78, junho. 2009.

[41] NAKAMURA, J. Escolha de fôrmas para paredes de concreto deve considerar critérios técnicos e econômicos. Revista Téchne, n. 202, janeiro. 2014.

[42] Neves, M. Processo Construtivo de Paredes de Concreto Moldadas In Loco em Fôrmas de Alumínio. Trabalho de conclusão de curso (Curso de Especialização em Produção e Gestão do Ambiente Construído) - Universidade Federal de Minas Gerais, 2017.

[43] POLAR, A. Conectores simples esgoto + posicionadores. Disponível em: <http://polar.com.br/hidraulica_laje_cs_esgoto.php>. Acesso em: 05 maio 2020.

[44] SAMPAIO, G.; CUNHA, G.; SILVA, M.; MANIER, R. Patologias em Parede de Concreto. Trabalho de conclusão de curso (Bacharelado em engenharia civil) - Universidade Federal do Rio de Janeiro, 2016.

[45] SANTOS, V. F. Paredes de concreto com fôrmas metálicas. Revista Téchne, n 169, abril 2011.

[46] SILVA, F. Fôrmas de alumínio para moldagem de paredes estruturais no local. Revista Téchne, n 160, julho 2010.

[47] VASCONCELOS, G.W. Construções de Edificações Residenciais Populares Utilizando a Tecnologia de Parede de Concreto. Trabalho de conclusão de curso (Bacharelado em engenharia civil) - Universidade Federal do Sul de Santa Catarina, Palhoça, 2017.

[48] VENTURINI, Jamila. Casas com paredes de concreto. Revista Equipe de Obra. Disponível em: < https://docplayer.com.br/1991443-Casas-com-paredes-de-concreto-reportagem-jamila-venturini.html >. Acesso em: 08 maio 2020. 


\section{Capítulo 6}

\section{Análise comparativa entre piso cerâmico prensado e piso cerâmico extrudado em cozinha industrial}

\section{Lucimir Azevedo Monteiro Neto \\ Sara dos Santos Santarém \\ Luciane Farias Ribas}

Resumo: 0 estudo parte da importância da constante inovação do mercado, uma tendência da indústria 4.0, que busca incorporar inovações como meio de elevar a produtividade e competitividade do setor. Dessa forma, observa-se que a evolução não se restringe a automação e inteligência artificial, de modo a alcançar a reformulação dos materiais. 0 progresso sobre os produtos disponíveis, nos possibilita explorar os tipos de revestimentos cerâmicos para uso em projetos de alta complexidade. Assim, define-se que o ambiente de estudo escolhido é a cozinha industrial, uma vez que é necessário assegurar que a mesma contemple funcionalidade, tornando inábeis os riscos de contaminação de alimentos, bem como de acidentes de trabalho. A presente monografia tem por finalidade analisar de modo comparativo dois destes revestimentos cerâmicos que podem ser aplicados na cozinha. Esse estudo selecionou o piso cerâmico prensado, já conhecido dos usuários e o piso cerâmico extrudado, cada vez mais utilizado nestes espaços dentro das indústrias. Para esta análise foram realizadas pesquisas em campo, em duas indústrias, de modo a avaliar todas as condicionantes e ao final, designar um comparativo técnico e financeiro de ambos os tipos examinados. Os resultados apontam que dentre ambos, o piso cerâmico extrudado é o mais adequado a este tipo de ambiente.

Palavras-chave: Cozinha industrial; Revestimentos cerâmicos; Comparativo técnico e financeiro. 


\section{INTRODUÇÃO}

É notório que a história da civilização está atrelada a da cerâmica. Ao analisar as inúmeras habilidades desenvolvidas desde os primórdios, observa-se que a necessidade de conquistar o alimento para sua sobrevivência, fez com que o homem passasse a fabricar seus utensílios, utilizando a argila. Desse modo, surgem as primeiras peças de cerâmica. A partir desse momento, este material aprimorou-se, no mesmo espaço de tempo, em todos os continentes.

A procura por alimento, que teve início na origem da civilização, resultou na conveniente situação do homem contemporâneo. Atualmente, a comida encontra-se disponível em ampla escada, por todos os lugares, sem que aja necessidade de empenho para obtê-la. E a consequência desta grande demanda de produção de refeições, reflete na necessidade de atender requisitos específicos para com os ambientes de manipulação destes alimentos.

Para que o desempenho venha a ser cumprido, é necessário estar sempre atento aos produtos oferecidos pelo mercado, bem como suas novidades tecnológicas que permitam um resultado melhor. Ao abordar esta temática, tocaremos no ponto pertinente a nossa pesquisa, o revestimento cerâmico utilizado nas cozinhas industriais.

Uma vez que aborda-se acerca do revestimento cerâmico, define-se o termo cerâmica afim de apresentar conceitos básicos a compreensão de nosso estudo. A cerâmica pode ser estabelecida como a composição de rudimentos inorgânicos, elaborados a partir da exposição a elevadas temperaturas.

A presente monografia tem por objetivo investigar comparativamente dois tipos de revestimento cerâmico que podem ser aplicados na cozinha industrial, sendo, o piso prensado e o piso extrudado.

Ao decorrer do trabalho deve-se apresentar cada um. De modo a conhecer sobre suas características, seus modos de fabricação e as classificações que podem ser aplicadas seguindo normas e outras fontes pertinentes ao tema. Uma vez que estas informações sejam apresentadas, iremos instituir um comparativo técnico e financeiro sobre os dois tipos de revestimento. E por fim, verificar qual destes é o mais adequado, com base em uma revisão bibliográfica.

\section{REFERENCIAL TEÓRICO}

\subsection{DEFINIÇÃO DA CERÂMICA}

Ao propor a conceituação da cerâmica, utiliza-se algumas noções propostas por diferentes associações. 0 termo "cerâmicas" vem do grego kéramos, que significa terra ou argila queimada, conforme a ANFANCER (2020). Ela também pode ser definida como "à pedra artificial obtida pela moldagem, secagem e cozedura de argilas ou de misturas contendo argila" (BAUER, 2014, p. 526).

Outra concepção a ser elucidada é da ABCERAM (2020), que define a cerâmica como o acúmulo de elementos inorgânicos, em sua forma integral, exceto os não metálicos. Esta combinação, é exposta a temperaturas elevadas, em tratamento térmico, chegando ao resultado final conhecido. 0 terceiro conceito a ser explanado, consta na NBR 13.816 (ABNT,1997), onde esta a descreve como o aglomerado de insumos, sendo alguns destes compostos de argila, assim como de elementos minerais.

Segundo a NBR 13.818 (ABNT, 1997), as caixas ou as placas cerâmicas devem identificar à natureza da sua superfície, podendo ser classificadas como, esmaltada ou não esmaltada. De acordo com a ABCERAM (2020), o esmalte ou vidrados são uma mescla de matéria-prima natural com elementos químicos aplicados sobre a parte superior da placa cerâmica, que após a sua queima, forma uma camada contínua, vítrea e delgada. Segundo a NBR 13.817 (ABNT, 1997), os revestimentos cerâmicos podem ser classificados por grupos de absorção de água e por métodos de fabricações, conforme mostra o Quadro 1.

Quadro 1 - Grupos de absorção de água

\begin{tabular}{|c|c|c|c|}
\hline \multirow{2}{*}{ Absorção de água (\%) } & \multicolumn{3}{|c|}{ Métodos de fabricação } \\
Extrudado (A) & $\begin{array}{c}\text { Prensado (B) } \\
\text { Outros (C) }\end{array}$ \\
\cline { 1 - 1 } Absorção $<0,5$ & AI & BIa & CI \\
$0,5<$ Absorção $\leq 3$ & AIIa & BIIa & CIIa \\
\hline $3<$ Absorção $\leq 6$ & AIIb & BIIb & CIIb \\
\hline $6<$ Absorção $\leq 10$ & AIII & BIII & CIII \\
\hline Absorção $>10$ & 10 &
\end{tabular}


Para um melhor entendimento do Quadro 1, vê-se que, conforme estudos desenvolvidos pela NBR 13.817 (ABNT, 1997), são utilizados para os métodos de fabricações A - prensado, B - extrudado e C - outros. Assim como por grupos de absorção de água, subdivididos em I, II e III. Segundo o INMETRO (2020), o grau de absorção de água influencia nas propriedades mecânicas das placas cerâmicas. É através deste estágio que passamos a ter subdivisões das cerâmicas, sendo estas: porcelanatos, grês, semi-grês, semiporosos e porosos. Portanto, quanto maior a absorção de água pela peça, menor é a resistência mecânica. Para revestimentos cerâmicos, como o azulejo que correspondem a classificação BIII, o seu grau de absorção é maior que $10 \%$, portanto, é recomendável que este seja aplicado somente em superfície de parede, dada a sua baixa resistência mecânica.

Ao analisar o Quadro 1, percebe-se que os pisos cerâmicos, que são condizentes com as classificações AI (Extrudados), Bla (prensados) e CIA (outros), tem seu grau de absorção menor que 0,5\%, logo obtêm menor capacidade de absorção de água, portanto orienta-se que seja utilizado em áreas molhadas e úmidas, como banheiros, cozinhas, área de serviço e lavanderia (INMETRO, 2020).

\subsection{MÉTODO DE FABRICAÇÃO DOS PISOS CERÂMICOS}

Ao discutir uma análise comparativa sobre o piso cerâmico prensado e o piso cerâmico extrudado, é necessário que se estabeleça o entendimento quanto a produção de ambos. Ao abordar a fabricação de qualquer placa cerâmica, nota-se que este ciclo ocorre em etapas, sendo extração e preparação da matériaprima, preparação da massa cerâmica, conformação, secagem, esmaltação e queima.

Todo material cerâmico necessita dos processos de conformação plástica, uma vez que possuem elevado ponto de fusão e um comportamento mecânico frágil, sendo sua produção iniciada em forma de pó, com a consistência variável dependendo da quantidade de água adicionada. A produção ocorre a partir da extração da argila, onde este é removido de depósitos naturais de argila, também conhecido barreira. Eles são encontrados, em geral, afastadas das fábricas, dado a qualidade da matéria-prima aos arredores não ser satisfatória na maioria das vezes.

A matéria-prima extraída passa por algumas etapas de análises afim de haver controle de qualidade. Este preparo inicia-se ainda na jazida separando lotes com a mesma dureza, plasticidade e demais premissas. Após esta divisão, ocorrem ainda o apodrecimento da argila, maceração, correção e amassamento. De acordo com Bauer (2014), a maceração sucede ao colocar a argila em caixas, sendo agitada por força humana ou animal, onde são retirados galhos, pedras ou outros corpos que estejam misturados. É feita a correção para que a argila seja composta da maneira que for adequada ao seu uso. E o recurso do amassamento prepara a matéria para a moldagem, sendo realizados de maneira manual ou mecânico a partir do tipo de argila e o tipo de moldagem Uma vez que todos os preparativos são feitos, as matériasprimas tendem a ser dosados. Conforme Oliveira et al. (2015), o sistema de dosagem precisa as quantidades pertinentes a matéria-prima que irão compor a massa cerâmica líquida, chamada de barbotina. A mistura dosada é armazenada temporariamente em um depósito, sendo posteriormente carregada para um moinho de tambor.

Ainda que os métodos tecnológicos empregados para a produção dos revestimentos cerâmicos tenham diferenças de processo, podem ser observadas divergências essenciais durante o período de preparação da massa cerâmica. De acordo com Oliveira et al. (2015), o procedimento chamado de moagem tem como propósito a fragmentação e a homogeneização e pode ser realizado de duas maneiras, sendo a designação entre os tipos dada pela qualidade do insumo. Uma metodologia consiste na moagem dos elementos sem adição de água. Já a outra técnica, compreende na moagem da matéria-prima com a adição da água e por seguinte a secagem por spray, conhecida por atomização. A etapa por seguinte trata do processo de conformação, que configura cada um dos pisos que serão abordados neste trabalho, sendo estes:

\section{a) prensagem}

A primeira metodologia a ser explanada é a prensagem. A metodologia de conformação mais operado pela indústria de produtos cerâmicos, uma vez que a mesma tem alto rendimento, possibilidade de fabricação de peças de variados tamanhos e formatos, fácil automação e outros. Como mostra a Figura 1, a prensagem em molde flexível, normalmente aplicado em fôrmas complexas, onde a mesma comprova relevo em várias direções.

Consoante a Oliveira et al. (2015), o processo de prensagem tem por finalidade a obtenção de elementos uniformes, concordantes com a geometria e dimensões já pré-estabelecidas, de modo que as pressões de 
compactação exercidas sob os pós formam gradientes de densidade evidente nas peças prensadas. Isto torna possível que ocorra a retração e porosidade diferentes após a queima.

\section{b) Extrusão}

A outra técnica de conformidade a ser apresentada, segundo Oliveira et al. (2015), trata-se da extrusão. 0 processo consiste no escoamento de determinado material plástico coeso, por meio de um orifício de um molde rígido adequado à pressão que será aplicada. Conforme a Figura 2, vê-se um exemplo de extrusora de materiais cerâmicos. Posteriormente, é desenvolvida a etapa de secagem, onde há a eliminação da umidade dos produtos que passaram pela prensagem ou extrusão. De acordo com Moraes (2010), as placas cerâmicas são transferidas por rolos móveis para secadores verticais, tendo os ciclos entre 35 a 70 minutos ou horizontais, com ciclos de 6 a 20 minutos.

Ao passar pelo processo de secagem, a peça cerâmica é direcionada a esmaltação, através de aplicações de métodos a seco e a úmido. Conforme indicado em Oliveira et al. (2015), é aplicado sobre o elemento uma camada fina e contínua de um material. Há diversos esmaltes com propriedades particulares que requisitam uma importante elasticidade nos espaços de trabalho. Por fim, como último processo de fabricação temos a queima. 0 processo todo é bem elucidado por Oliveira et al. (2015). É realizada em fornos contínuos, conhecidos como túnel ou intermitentes, onde o elemento é exposto a altas temperaturas, que aprimoram a dureza e a resistência e diminuem a porosidade. 0 procedimento inicia-se com o aquecimento, estadia ao estágio máximo no período de tempo necessário e por fim, o resfriamento.

\subsection{CLASSIFICAÇÃO}

\subsubsection{CLASSES DE RESISTÊNCIA À ABRASÃO SUPERFICIAL}

Conforme observado pela análise do INMETRO (2020), o índice PEI é uma classificação da cerâmica, resultado da realização de testes de resistência do esmalte da placa cerâmica, por desgaste à abrasão superficial. Em ambientes onde observa-se que há um alto índice de fluxo de pessoas e equipamentos, é visto que para não ocorrer danos ao corpo cerâmico, é necessária uma maior resistência em relação ao teste de abrasão. Quando se trata de cerâmica esmaltada, esta pode ser classificada em escalas PEI, que variam entre 1 à 5 (INMETRO, 2020), de acordo com Quadro 2.

Quadro 2: Classes de resistência à abrasão superficial

\begin{tabular}{|c|c|c|}
\hline PEI & Resistência à abrasão & Uso \\
\hline 1 & Baixa & $\begin{array}{l}\text { Áreas residenciais utilizando chinelo ou descalço em quartos e } \\
\text { banheiros sem acesso ao local externo. }\end{array}$ \\
\hline 2 & Média & $\begin{array}{l}\text { Áreas residenciais utilizando sapatos na maioria das dependências } \\
\text { residenciais, excluso somente áreas de entrada e cozinha. }\end{array}$ \\
\hline 3 & Média Alta & $\begin{array}{l}\text { Áreas residenciais em que pode haver sujeira abrasiva que não seja } \\
\text { uma solidez maior que areia utilizando em todos ambientes } \\
\text { residenciais. }\end{array}$ \\
\hline 4 & Alta & $\begin{array}{l}\text { Toda área residencial e comercial com alto tráfego: churrascarias, } \\
\text { lojas, bancos, entradas, vendas e exposições abertas a sociedade, entre } \\
\text { outras. }\end{array}$ \\
\hline 5 & Altíssima & $\begin{array}{l}\text { Áreas comerciais e residenciais com tráfego bastante elevado: } \\
\text { restaurantes, lanchonetes, lojas, bancos, entradas, corredores, } \\
\text { exposições abertas a sociedade, consultório, entre outras. }\end{array}$ \\
\hline
\end{tabular}

Fonte: INMETRO (2020), adaptado.

\subsubsection{CLASSES DE RESISTÊNCIA AO MANCHAMENTO}

Conforme dados do IAU (2020), as classes de manchas detêm uma variação de 1 a 5 . Esse teste aponta, em termos práticos, a capacidade de higienização do revestimento cerâmico. De acordo com a NBR 13.817 (ABNT, 1997), obtemos a classificação quanto a resistência ao manchamento, no Quadro 3. 
Quadro 3: Resistência a manchas (classes de limpabilidade)

\begin{tabular}{|c|l|}
\hline Classe & \multicolumn{1}{c|}{ Remoção da Mancha } \\
\hline 5 & Maior facilidade de remoção - com água quente \\
\hline 4 & Removível com produto de limpeza fraco - detergente neutro \\
\hline 3 & Removível com produto de limpeza forte - saponáceo \\
\hline 2 & Removível com ácido clorídrico, hidróxido de potássio, tricloroetileno \\
\hline 1 & Impossibilidade de remoção da mancha \\
\hline
\end{tabular}
Fonte: NBR 13.817 (1997).

Logo, constata-se que quanto maior for a classe de macha, maior a facilidade de limpeza do revestimento cerâmico.

\subsubsection{CLASSES DE RESISTÊNCIA AO ATAQUE DE AGENTES QUÍMICOS}

Assim como afirmado pelo IAU (2020), a resistência aos agentes químicos é a capacidade da superfície cerâmica permanecer intacta, quando exposta a produtos e elementos químicos. Os ataques químicos mais recorrentes são a utilização de produtos de limpeza, ácidos e álcalis. Consoante a NBR 13.817 (ABNT, 1997), tem-se a classificação do revestimento de placas cerâmicas quanto a resistência a agentes químicos, no Quadro 4.

Quadro 4: Classificação de resistência a ataque químico

\begin{tabular}{|c|c|}
\hline Classificação & Definição \\
\hline A & Boníssima resistência a produtos químicos \\
\hline $\mathrm{B}$ & Rápida alteração de aspecto \\
\hline $\mathrm{C}$ & Alteração de aspecto bastante definida \\
\hline
\end{tabular}
Fonte: INMETRO (2020), adaptado.

O Quadro 5 expressa as terminologias utilizadas, segundo identificado na NBR 13.817 (ABNT, 1997).

Quadro 5: Terminologia para resistência química

\begin{tabular}{|l|c|c|c|c|}
\hline \multicolumn{1}{|c|}{ NIIVEIS DE RESISTÊNCIA QUÍMICA } \\
TIPOS DE PRODUTOS & Alta & Média & Baixa \\
\hline \multirow{2}{*}{ PRODUTOS DOMÉSTICOS E DE PISCINA } & A & B & C \\
\hline \multirow{2}{*}{ ÁCIDOS E ÁLCALIS } & Alta concentração H & HA & HB & HC \\
\cline { 2 - 5 } & Baixa concentração L & LA & LB & LC \\
\hline \multicolumn{2}{|c|}{ Fonte: ABNT NBR 13.817 (1997). }
\end{tabular}

Acerca da classificação de resistência ao ataque de agente químicos, a NBR 13.817 (ABNT, 1997), descreve a placa cerâmica sendo esmaltada ou não-esmaltada, passando por um ataque químico diferente conforme seu tipo.

Em caráter complementar, deve se fazer referência com a letra inicial ao tipo de placa cerâmica, sendo "G" para esmaltada (glazed) ou "U" para não esmaltada (unglazed). Como demonstrado na seguinte sequência:

- $\quad$ Primeira Letra: G ou U: Esmaltada ou não esmaltada;

- $\quad$ Segunda Letra: H ou L: Alta ou baixa concentração;

- $\quad$ Terceira Letra: classes de resistência químicas: A, B ou C, sendo respectivamente: alta, média e baixa.

\subsubsection{ASPECTO SUPERFICIAL OU ANÁLISE VISUAL}

Como averiguado na NBR 13.818 (ABNT, 1997), classificam-se como produtos de alta qualidade, quando no mínimo 95\% das placas cerâmicas examinadas não possuem defeitos visuais na distância padrão de observação $(1,00 \mathrm{~m} \pm 0,05 \mathrm{~m})$. É necessário observar as seguintes imperfeições: rachaduras, depressões, crateras, bolhas, furos, pintas, etc. 


\section{METODOLOGIA}

\subsection{COZINHA INDUSTRIAL}

De acordo com Colares et al. (2007), um local em que é realizado a alimentação coletiva, com o intuito de fornecer refeições balanceadas nutricionalmente, seguindo as diretrizes de higiene-sanitária para consumo fora do ambiente domiciliar. Assim, denomina-se unidade de alimentação coletiva, podendo ser cozinhas, escolas, hospitais etc.

Segundo Monteiro et al. (2004), uma das principais características de um revestimento de piso cerâmico em cozinha industrial, é que o mesmo deve suportar um elevado tráfego de pessoas, bem como de instrumentos pesados, como visto na Figura 3. Outra característica essencial refere-se ao piso ser antiácido, para que suporte a agressividade dos produtos de limpeza através da ação dos componentes químicos.

Figura 14: Utensílios e equipamentos pesados

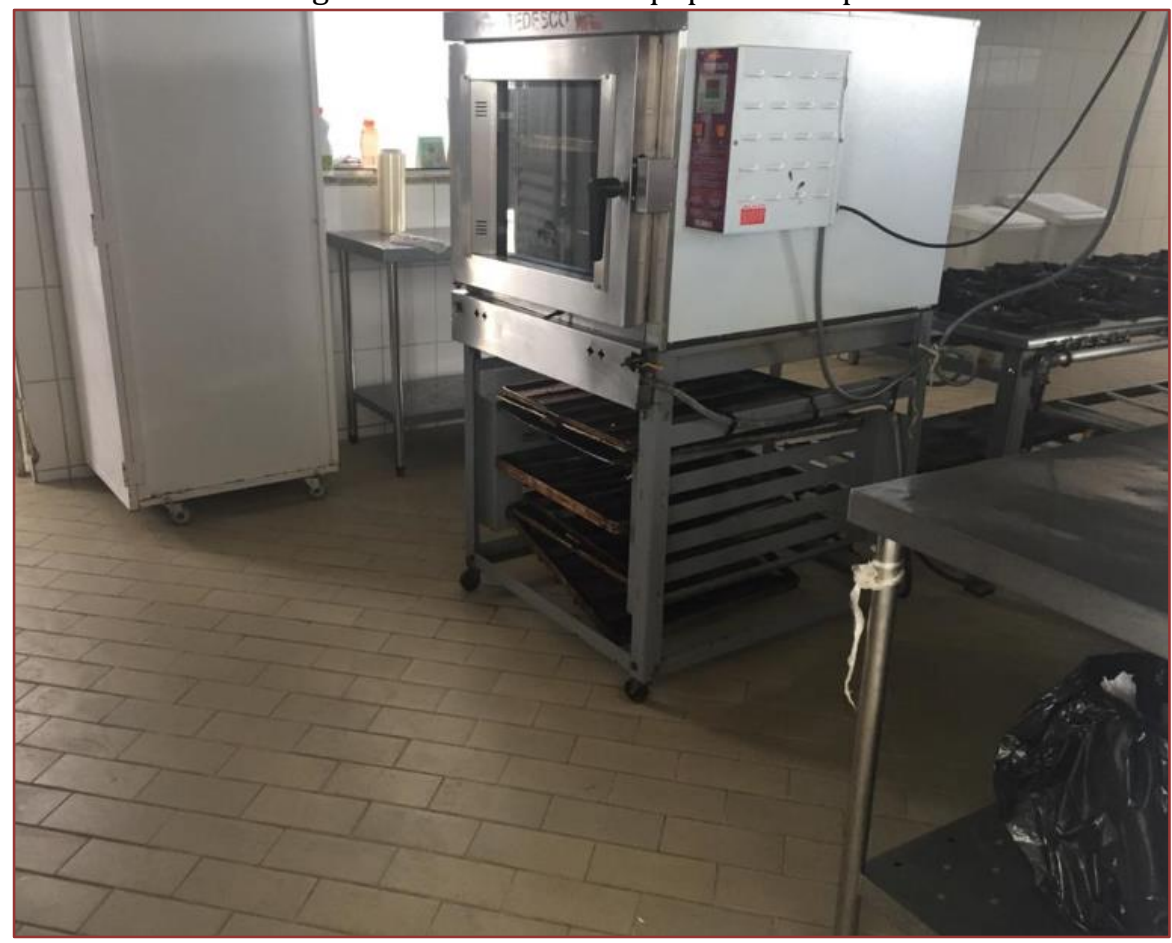

Fonte: Acervo pessoal.

Além destes atributos, pode-se citar também a necessidade deste ser antiderrapante, por tratar-se de uma área molhada e proveniente de gorduras, água, óleos e variadas substâncias que podem vir a serem manuseadas. E por fim, ter a propriedade que lhe permita suportar altas temperaturas, dado a utilização de fornos e caldeiras, entre outros.

\subsection{CARACTERÍSTICAS FÍSICAS DOS LOCAIS VISITADOS}

Para uma melhor compreensão desta etapa serão denominadas cada uma das cozinhas que foram objetos de estudo dessa análise. Sendo, aquela com o piso cerâmico prensado nomeada de cozinha industrial $1 \mathrm{e}$ aquela com piso cerâmico extrudado de cozinha industrial 2.

É importante ressaltar que foi constatado que durante a visita técnica, acontecia uma reforma na cozinha industrial 1, sendo definido pela fábrica que o piso a ser colocado seria a cerâmica prensada com aplicação piso sobre piso, conforme visto na Figura 4. 0 levantamento realizado na cozinha industrial 2 ocorreu durante o turno matutino, visto que este horário asseguraria a não contaminação nos processos alimentícios. A cozinha industrial 2 foi inaugurada há um ano, não passando por nenhum reparo além da manutenção corriqueira. 
Figura 4: Piso cerâmico prensado

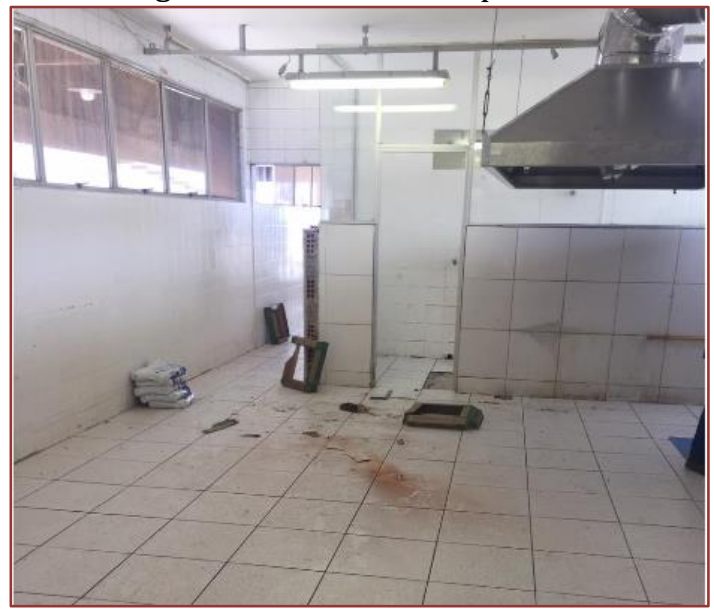

Fonte: autoria própria.

Figura 5: Piso cerâmico extrudado

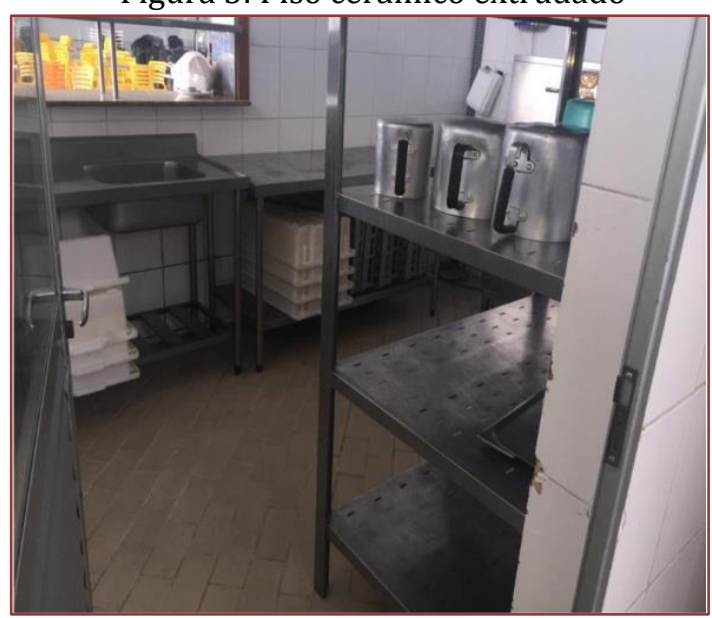

Fonte: autoria própria.

Em ambas as imagens, é possível observar os modelos de pisos aplicados na mesma tipologia de ambiente, que trata-se da cozinha industrial. Na Figura 4, tem-se o piso cerâmico de tipo prensado e na Figura 5 , o piso cerâmico de tipo extrudado.

Para a análise comparativa, estabelece-se duas marcas encontradas no mercado atual da cidade de Manaus. 0 primeiro material definido é o revestimento de tipo prensado, sendo selecionada a cerâmica Icapuí, na cor branca em formato quadrado, com as dimensões 456,5 x 456,5 x 6,4 mm, pertencente ao grupo de absorção BIIb (Quadro 1) e com o tardoz polidirecional, que trata-se de ranhuras em variadas direções. 0 segundo revestimento selecionado é referente ao tipo extrudado, optando pelo piso cerâmico Gail, na cor bege em formato retangular, com as dimensões $240 \times 116$ × 9 mm, pertencente ao grupo de absorção AI (Quadro 1) e com tardoz monodirecional, que indica ranhuras na mesma direção.

\subsection{MAPA DE COTAÇÃO DE MERCADO}

Para gerar um mapa de cotação, é necessária uma elaboração de planilha, comumente realizada no software Excel, de modo a fazer um comparativo de preços entre os dois tipos de cerâmica interpelados. Visto que, segue-se uma sequência, iniciada a partir das cotações na cidade de Manaus. Ao elaborar o mapa de cotação de mercado, observa-se que existem diversos métodos de pesquisa. Conforme estabelecido pelo TCU (2014), para cotações efetuadas de maneira direta com provedores, é necessário que os preços a serem empregados tenham somente 180 (cento e oitenta) dias, a contar da data da cotação. Portanto, qualquer cotação realizada diretamente ao provisor, quando comparada as demais, devem se manter neste período afim de prosseguir a pesquisa justa. Um dos pontos que se faz necessário destacar nesta pesquisa, é o motivo de ter de constar apenas uma cotação das cerâmicas Gail. A razão desta, é por existir apenas um representante da marca aqui em Manaus. Segundo o TCU (2014), quando não for possível 
apresentar as três propostas requisitadas em norma, é fundamental que seja identificado e informado o motivo da mesma.

\subsection{ANÁLISES FÍSICO-QUÍMICAS DAS PLACAS CERÂMICAS ESTUDADAS}

Para que seja realizado um exame técnico comparativo, em âmbito teórico, foram elaborados diversos estudos em duas cozinhas distintas, cada qual com seu determinado tipo de piso, ambos abordados neste trabalho. A seguir são apresentadas as propriedades analisadas.

\subsection{ANÁLISE DE ABSORÇÃO DE ÁGUA}

Os dados fornecidos pela Tabela 1, são referentes ao grau de absorção de água que cada placa cerâmica possui. Portanto, compreende-se que ambos os pisos atendem os requisitos, impostos pela norma NBR 13.818 (ABNT, 1997).

Tabela 1: Comparativo do grau de absorção de água nas placas cerâmicas

\begin{tabular}{|c|c|c|c|}
\hline \multirow{2}{*}{\multicolumn{4}{|c|}{$\begin{array}{c}\text { Características Físicas para todos os usos } \\
\text { Grupos de absorcão AI (extrudado) } \quad \text { Grupos de absorcão BIIb (prensado) }\end{array}$}} \\
\hline & & & Grupos de absorção BIIb (prensado) \\
\hline Cerâmica Bege (Gail) & Exigência NBR 13818 & Cerâmica Icapuí Branco (Cerbrás) & Exigência NBR 13818 \\
\hline \multicolumn{4}{|c|}{ Umidade (\%) } \\
\hline$\leq 3$ & $\leq 3$ & $6<$ abs $<10$ & $6<$ abs $<10$ \\
\hline
\end{tabular}

Fonte: ABNT NBR 13.818 (1997), adaptado.

A permeabilidade e porosidade de um revestimento cerâmico são incumbências de uma propriedade da cerâmica, nomeada como absorção de água. 0 entendimento obtido indica que, quanto maior a incidência da compactação da cerâmica, menor a sua absorção de água (IAU, 2020).

\subsection{ANÁLISE DA CARGA DE RUPTURA}

Conforme a Tabela 2, obtemos dados examinados quanto a resistência a carga de ruptura que cada placa resiste. Analisando a tabela, torna-se evidente que, tanto o Icapuí quanto o Gail, atendem a norma da NBR 13.818 (ABNT, 1997).

Tabela 2: Comparativo da carga de ruptura das placas cerâmicas

\begin{tabular}{|c|c|c|c|}
\hline \multicolumn{4}{|c|}{ Características Físicas para todos os usos } \\
\hline \multicolumn{2}{|c|}{ Carga de ruptura - Grupo AI (extrudado) } & \multicolumn{2}{|c|}{ Carga de ruptura - Grupo BIIb (prensado) } \\
\hline $\begin{array}{l}\text { Cerâmica Bege } \\
\text { (Gail) }\end{array}$ & Exigência NBR 13818 & Cerâmica Icapuí Branco (Cerbrás) & Exigência NBR 13818 \\
\hline \multicolumn{2}{|c|}{ Espessura $>7,5 \mathrm{~mm}$} & \multicolumn{2}{|c|}{ Espessura $<7,5 \mathrm{~mm}$} \\
\hline \multicolumn{4}{|c|}{ Unidade (N) } \\
\hline$\geq 1400$ & $\geq 1100$ & $\geq 500$ & \\
\hline
\end{tabular}

Com a análise, ressaltar-se que a cerâmica Gail, apresenta uma resistência a carga de 1400 newtons, de modo a superar os 300 newtons, que é a carga exigida pela norma. Outro ponto encontrado nesta pesquisa, consiste na resistência a carga de 500 newtons da cerâmica Icapuí, de modo a atender acima do mínimo estipulado pela NBR 13.818 (ABNT, 1997).

\subsection{ANÁLISE DA EXPANSÃO POR UMIDADE}

Como visto na Tabela 3, são exibidos os dados acerca da expansão por umidade, correspondente a cada revestimento abordado nesse exame. Assim como no item anterior, as duas placas cerâmicas atendem os requisitos da norma NBR 13.818 (ABNT, 1997). 
Tabela 3: Comparativo da expansão por umidade das placas cerâmicas

\begin{tabular}{|c|c|c|c|}
\hline \multicolumn{4}{|c|}{ Características Físicas para todos os usos } \\
\hline \multicolumn{2}{|c|}{ Expansão por umidade - Grupo AI (extrudado) } & \multicolumn{2}{|c|}{ Expansão por umidade - Grupo BIIb (prensado) } \\
\hline Cerâmica Bege (Gail) & Exigência NBR 13818 & Cerâmica Icapuí Branco (Cerbrás) & Exigência NBR 13818 \\
\hline \multicolumn{4}{|c|}{ Unidade $(\mathrm{mm} / \mathrm{m})$} \\
\hline$\leq 0,6$ & Por acordo & $\leq 0,6$ & Por acordo \\
\hline
\end{tabular}

A expansão por umidade acontece com frequência em lugares com elevado teor de lubricidade. Os ambientes acometidos são, em geral, a cozinha industrial, banheiros e saunas. Esta característica tende a aumentar as dimensões das placas cerâmicas, uma vez que as mesmas absorvem a umidade, através das partículas de argila (IAU, 2020).

\subsection{ANÁLISE DO COEFICIENTE DE ATRITO DINÂMICO}

Para a Tabela 4, temos a apresentação de um comparativo entre os coeficientes de atrito do piso cerâmico Icapuí e do pisco cerâmico Gail.

Tabela 4: Comparativo do coeficiente de atrito

$$
\text { Características Físicas para usos específicos }
$$

\begin{tabular}{|c|c|c|c|}
\hline \multicolumn{4}{|c|}{ Características Físicas para usos específicos } \\
\hline Coeficiente de atrit & irupo AI (extrudado) & Coeficiente de atrito - Gru & IIb (prensado) \\
\hline Cerâmica Bege (Gail) & Exigência NBR 13818 & Cerâmica Icapuí Branco (Cerbrás) & Exigência NBR 13818 \\
\hline$\geq 0,7$ & A declarar & $\leq 0,4$ & A declarar \\
\hline
\end{tabular}

Fonte: ABNT NBR 13.818 (1997), adaptado.

O que se avalia neste coeficiente, é o quanto a peça pode torna-se escorregadia, ao entrar em contato com água. Os coeficientes $\geq 0,4$, são recomendados para uso onde seja necessária à resistência ao escorregamento (ABNT NBR 13818, 1997).

\subsection{ANÁLISE DE RESISTÊNCIA AO MANCHAMENTO}

De acordo com a Tabela 5, são expostos os dados relativos ao comparativo de resistência ao manchamento. Ao analisar a tabela, é perceptível que as duas cerâmicas atendem as exigências da norma regulamentadora.

Tabela 5: Comparativo de resistência ao manchamento

\begin{tabular}{|c|c|c|c|}
\hline \multicolumn{4}{|c|}{ Características Químicas para todos os usos } \\
\hline \multicolumn{2}{|c|}{ Resistência ao manchamento - Grupo AI (extrudado) } & \multicolumn{2}{|c|}{ Resistência ao manchamento - Grupo BIIb (prensado) } \\
\hline Cerâmica Bege (Gail) & Exigência NBR 13818 & $\begin{array}{l}\text { Cerâmica Icapuí Branco } \\
\text { (Cerbrás) }\end{array}$ & Exigência NBR 13818 \\
\hline$\geq 5$ & A declarar & $\geq$ classe 3 & $\geq$ classe 3 \\
\hline
\end{tabular}

Portanto, infere-se que quanto maior a sua classe, melhor a sua limpabilidade. É valido destacar que, o grau de resistência ao manchamento pode ser inversamente proporcional ao grau de atrito. Isso ocorre porque alguns corpos cerâmicos com a superfície granilhadas podem tornar mais difícil a limpeza (IAU, 2020).

\subsection{ANÁLISE DE RESISTÊNCIA}

A análise de resistência química para todos os usos, focados no tratamento em piscinas e uso doméstico é demonstrada na Tabela 6 , na qual foram realizadas uma investigação entre os dois revestimentos abordados nessa pesquisa. 
Tabela 6: Comparativo da resistência química para uso doméstico e tratamento em piscinas

\begin{tabular}{|c|c|c|c|}
\hline \multicolumn{4}{|c|}{ Características químicas para todos os usos } \\
\hline \multicolumn{2}{|c|}{$\begin{array}{c}\text { Resistência química para uso doméstico e tratamento } \\
\text { em piscinas - Grupo AI (extrudado) }\end{array}$} & \multicolumn{2}{|c|}{$\begin{array}{l}\text { Resistência química para uso doméstico e tratamento } \\
\text { em piscinas - Grupo BIIb (prensado) }\end{array}$} \\
\hline Cerâmica Bege (Gail) & Exigência NBR 13818 & $\begin{array}{l}\text { Cerâmica Icapuí Branco } \\
\text { (Cerbrás) }\end{array}$ & Exigência NBR 13818 \\
\hline UA & $\geq$ classe UB & $\geq$ classe $\mathrm{GB}$ & $\geq$ classe GB \\
\hline
\end{tabular}

Fonte: ABNT NBR 13.818 (1997), adaptado.

Ao constatar que ambas atendem a norma, nota-se que a cerâmica Gail é classificada pela fabricante como um elemento de superfície não esmaltada e de alta resistência química. E quanto a cerâmica Icapuí, a classificação recebida a define como uma peça com a superfície esmaltada e com média resistência química (ABNT NBR 13818, 1997).

\subsection{ANÁLISE DE RESISTÊNCIA AOS AGENTES QUÍMICOS}

Um dos pontos importantes nesta análise, é a comparação quanto ao uso específico de resistência química de alta concentração. A cozinha industrial requer uma frequente higienização, afim de evitar acúmulo de gordura, assim como proliferação de sujeira e bactérias.

Tabela 7: Comparativo da resistência aos agentes químicos de alta concentração Características químicas para usos específicos

\begin{tabular}{|c|c|c|c|}
\hline \multicolumn{4}{|c|}{ Características químicas para usos específicos } \\
\hline \multicolumn{2}{|c|}{$\begin{array}{c}\text { Resistência aos agentes químicos (alta concentração) - } \\
\text { Grupo AI (extrudado) }\end{array}$} & \multicolumn{2}{|c|}{$\begin{array}{l}\text { Resistência aos agentes químicos (alta concentração) - } \\
\text { Grupo BIIb (prensado) }\end{array}$} \\
\hline Cerâmica Bege (Gail) & Exigência NBR 13818 & $\begin{array}{l}\text { Cerâmica Icapuí Branco } \\
\text { (Cerbrás) }\end{array}$ & Exigência NBR 13818 \\
\hline UHA & A declarar & GLB & A declarar \\
\hline
\end{tabular}

Fonte: ABNT NBR 13.818 (1997), adaptado.

Conforme a Tabela 7, torna-se evidente que o piso cerâmico Gail é um revestimento não esmaltado de alta concentração e o piso cerâmico Icapuí é um revestimento esmaltado de média concentração.

\section{RESULTADOS E DISCUSSÕES}

Este capítulo tem como finalidade salientar uma tabela, de modo a contribuir para análise comparativa entre os tipos de piso cerâmico, a partir dos dados apresentados. Como resultado, tem-se a cerâmica com melhor custo-benefício aplicado a fábrica, em relação ao ambiente da cozinha industrial. Os elementos designados para ser utilizados como parâmetros de seleção foram fundamentados em pesquisa bibliográfica.

Tabela 8 - Análise técnica dos revestimentos de piso cerâmico

\begin{tabular}{|c|c|c|c|}
\hline \multicolumn{2}{|r|}{ CARACTERÍSTICAS } & $\begin{array}{l}\text { CerâmicaPrensada Icapuí } \\
\text { Branco }\end{array}$ & Cerâmica Gail extrudada \\
\hline \multirow{4}{*}{$\begin{array}{l}\text { Propriedades } \\
\text { Físicas }\end{array}$} & Absorção de água (\%) & $6<\mathrm{abs}<10$ & $\leq 3$ \\
\hline & Carga de ruptura & $\geq 500$ & $\geq 1400$ \\
\hline & Expansão por umidade & $\leq 0,6$ & $\leq 0,6$ \\
\hline & Coeficiente de atrito dinâmico & $\leq 0,4$ & $\geq 0,7$ \\
\hline \multirow{3}{*}{$\begin{array}{l}\text { Propriedades } \\
\text { Químicas }\end{array}$} & Resistência ao manchamento & $\geq$ classe 3 & $\geq 5$ \\
\hline & $\begin{array}{l}\text { Resistência química (uso doméstico e } \\
\text { piscina) }\end{array}$ & $\geq$ classe GB & UA \\
\hline & Resistência aos agentes químicos & GLB & UHA \\
\hline
\end{tabular}

Fonte: Laudo técnico dos fabricantes (2020)

Como se observa na Tabela 8, uma vez que as sete características físico-químicas dos pisos abordados neste estudo passam pelo processo de análise, é a constatação de que a cerâmica Gail, sendo o tipo de piso cerâmico extrudado, é superior em $90 \%$ dos ensaios. A única exceção é quanto o aspecto de expansão por umidade, em razão de a cerâmica Icapuí, relacionada ao tipo de piso cerâmico prensado, apresentar o mesmo resultado da cerâmica Gail, sendo os 10\% restantes. 
Um fator de relevância, demonstrado no estudo, trata-se da carga de ruptura da cerâmica extrudada. Esta por sua vez resiste, aproximadamente, três vezes mais que a cerâmica prensada. Ao considerar o ambiente proposto, uma cozinha industrial, com existência de grande fluxo de pessoas e equipamentos de diversos tamanhos, pesos e formas, o piso que apresenta destaque é a cerâmica Gail.

Ao analisar a característica quanto a propriedade química, a cerâmica prensada Icapuí indica uma resistência a mancha de classe 3, portanto, aquela em que a mancha é removível com produto de alta concentração. No entanto, a cerâmica Gail indica pertencer a classe 5, o que expressa uma maior facilidade de limpeza, sem que seja necessário a utilização de produtos com alta concentração de limpeza, portanto apresentando um melhor desempenho.

Uma vez que o ambiente proposto é uma cozinha industrial e a mesma apresenta uma necessidade frequente de higienização, uma das características primordiais trata-se da resistência quanto a agentes químicos, estes presentes nos diversos produtos de limpeza utilizados na assepsia do local. Com base em laudos técnicos fornecidos pelos fabricantes, infere-se que o piso cerâmico Icapuí apresenta uma superfície esmaltada, com solução de baixa concentração e de classe média a resistência química. Enquanto, o piso cerâmico Gail expressa uma superfície não esmaltada, com solução de alta concentração e alta resistência química. Desse modo, evidencia-se o piso Gail como superior neste aspecto.

Muito embora, a cerâmica prensada atenda aos requisitos da norma NBR 13.818 (ABNT, 1997), verifica-se que ao confrontar com o piso prensado, este demonstra possuir uma maior resistência química, uma facilidade de higienização, pouca absorção e resistência ao congelamento. A partir destas características, compreende-se que a aplicação do piso Gail, dentre os revestimentos abordados, é a melhor indicação para este tipo de espaço, com indicação para áreas refrigeradas e congeladas, como as câmaras frias encontradas na cozinha.

Em caráter complementar, realizou-se uma análise comparativa dos custos dos pisos cerâmicos referidos, com base no mercado da cidade de Manaus. 0 resultado demonstra uma alta divergência de preços, como visto no Quadro 6, em que o piso cerâmico Icapuí é considerado cerca de $500 \%$ mais barato em relação ao piso cerâmico Gail, sendo o único aspecto em que pode ser apontado como superior.

\begin{tabular}{|c|c|c|c|c|c|c|}
\hline Item & Descrição & Und & Menor Preço & Empresa & $\begin{array}{c}\text { Preço } \\
\text { Unitário }\end{array}$ & Data \\
\hline \multirow{3}{*}{1} & \multirow{3}{*}{$\begin{array}{c}\text { Cerâmica para piso Icapuí } \\
\text { Branco 46x46cm, marca } \\
\text { Cerbrás }\end{array}$} & \multirow{3}{*}{$\mathrm{m}^{2}$} & \multirow{3}{*}{$\mathrm{R} \$ 16,99$} & Ck Pisos & $\mathrm{R} \$ 16,99$ & $16 / a b r$ \\
\hline & & & & $\begin{array}{c}\text { Telhacon Materiais de } \\
\text { Construção }\end{array}$ & $\mathrm{R} \$ 17,50$ & $16 / a b r$ \\
\hline & & & & Castelinho & $\mathrm{R} \$ 20,49$ & $16 / \mathrm{abr}$ \\
\hline 2 & $\begin{array}{l}\text { Gail placa cerâmica } \\
\text { extrudada }\end{array}$ & $\mathrm{m}^{2}$ & $\mathrm{R} \$ 89,00$ & $\begin{array}{l}\text { Boa Vista Comércio de } \\
\text { Frios e Materiais de } \\
\text { Construção Ltda. }\end{array}$ & $\mathrm{R} \$ 89,00$ & $16 / a b r$ \\
\hline
\end{tabular}

Fonte: Elaborado pelo autor (2020).

Desta forma, conclui-se que o revestimento cerâmico Gail detém um processo de fabricação mais complexo, de modo a justificar seu custo elevado quando comparado ao revestimento cerâmico Icapuí. 0 preço praticado torna-se compensatório, uma vez que o piso extrudado atende aos requisitos cruciais que uma cozinha industrial necessita, assim como assegura-se um desempenho mais duradouro que o outro tipo de piso.

\section{CONCLUSÃO}

O estudo teve como propósito analisar comparativamente, de forma técnica e financeira, a aplicação do piso cerâmico prensado e do piso cerâmico extrudado, no ambiente da cozinha industrial. Os dados ora apresentados neste trabalho demonstram como cada amostra corresponde aos requisitos específicos que este tipo de compartimento exige.

Ao propor esta investigação foi demonstrado acerca de suas características, os métodos de fabricação e o custo benefício de cada piso. Uma vez explanados estes dados, encaminhou-se para a seleção do piso, de modo a definir qual entre ambos era o mais adequado. A escolha do revestimento é responsável por proporcionar um melhor desempenho na produção de alimentos e repercute também na quantidade de manutenções periódicas que devem ser realizadas. 
Assim, buscando definir o revestimento mais apropriado, orientados em fundamentos científicos, foram esmiuçados ambos os pisos a partir de planilhas elaboradas com dados do fabricante e exigências feitas em normas pertinentes ao assunto. Ao todo, foram analisados oito pontos, sendo o mapa de cotação de mercado e os demais, um exame teórico de análises físico-químicas de ambos os revestimentos.

A partir dessa apuração foi averiguado que, ao realizar uma análise teórica, entre ambos os tipos apresentados, o piso cerâmico extrudado foi a peça melhor avaliada para este uso. No entanto, reitera-se que o resultado obtido pode ser alterado conforme a realização de testes em laboratório, com os recursos necessários e em posse do laudo técnico do fabricante.

Portanto, constatamos que o piso cerâmico adequado é aquele que consegue atender a variados aspectos normativos. Dessa forma, este trabalho pode elucidar de forma técnica os profissionais responsáveis pelo projeto e execução, assim como, as industriais e demais seguimentos que necessitam de grande demanda de produção de alimentos. Uma vez que estes apresentem interesse em investir em um material com alta performance e duradouro, a pesquisa pode auxiliar para que opte-se pelo produto com melhor desempenho.

\section{REFERÊNCIAS}

[1] ALBERO, J. L. Amorós. A Operação de Prensagem: Considerações Técnicas e sua Aplicação Industrial. In: ALBERO, J.L. Amorós. Parte I: O Preenchimento das Cavidades do Molde. Universidade de Valência, Espanha, p.23-28, 2009.

[2] AGÊNCIA NACIONAL DE VIGILÂNCIA SANITÁRIA (Brasil). In: RDC no 216: Regulamento técnico de boas práticas para serviços de alimentação. Brasília, DF: 2004. Disponível em: http://bvsms.saude.gov.br/bvs/saudelegis/anvisa/2004/res0216_15_09_2004.html. Acesso em 10 mar. 2020.

[3] ASSOCIAÇÃO BRASILEIRA DE CERÂMICA (Brasil). Cerâmica no Brasil: considerações gerais. São Paulo, SP. 2016. Disponível em: http://www.abceram.org.br/consideracoes-gerais/. Acesso em 28 fev. 2020.

[4] ASSOCIAÇÃO BRASILEIRA DE NORMAS TÉCNICAS. ABNT NBR 13816. Placas cerâmicas para revestimento: Terminologia. Rio de Janeiro, ABNT, 1997.

[5] ASSOCIAÇÃO BRASILEIRA DE NORMAS TÉCNICAS. ABNT NBR 13817. Revestimento de piso interno ou externo com placas cerâmicas e com utilização de argamassa colante: Procedimento. Rio de Janeiro, ABNT, 1996.

[6] ASSOCIAÇÃO BRASILEIRA DE NORMAS TÉCNICAS. ABNT NBR 13817. Placas cerâmicas para revestimento: Classificação. Rio de Janeiro, ABNT, 1997.

[7] ASSOCIAÇÃO BRASILEIRA DE NORMAS TÉCNICAS. ABNT NBR 13818. Placas cerâmicas para revestimento: especificação e métodos de ensaios. Rio de Janeiro, ABNT, 1997.

[8] ASSOCIAÇÃO BRASILEIRA DE NORMAS TÉCNINCS. ABNT NBR 13753. Revestimento de piso interno ou externo com placas cerâmicas e com utilização de argamassa colante - Procedimento. Rio de Janeiro, ABNT, 1996.

[9] ASSOCIAÇÃO BRASILEIRA DE NORMAS TÉCNICAS. ABNT NBR 14081-1. Argamassa colante industrializada para assentamento de placas de cerâmica: Parte 1: Requisitos. Rio de Janeiro, ABNT, 2012.

[10] ASSOCIAÇÃO NACIONAL DOS FABRICANTES DE CERÂMICA PARA REVESTIMENTO (Brasil). História da cerâmica. São Paulo, SP. 2016. Disponível em: http://www.anfacer.org.br/historia-ceramica. Acesso em 28 fev. 2020.

[11] BAUER, L. A. Falcão. Materiais de Construção: Novos Materiais para Construção Civil. In: BAUER, L.A. Falcão. Cerâmica. 5 ed. Rio de Janeiro: LTC, 2014, p.526-565, v.2.

[12] CENTRO FEDERAL DE EDUCAÇÃO TECNOLÓGICA DE MINAS GERAIS (Brasil). Extrusora para Materiais Cerâmicos. Belo Horizonte, Minas Gerais. 2018. Disponível em: http://www.demat.cefetmg.br/extrusora-paramateriais-ceramicos/. Acesso em 13 mai. 2020.
[13] CERBRAS
CERÂMICAS
PRODUTOS.
Disponível
em:

http://www.cerbras.com.br./produtos/ceramicas/granilhada/icapui-branco-026. Acesso em: 10 mai 2020

[14] COLARES, Luciléia Granhen Tavares; FREITAS, Carlos Machado de. Processo de trabalho e saúde de trabalhadores de uma unidade de alimentação e nutrição: entre a prescrição e o real do trabalho. Cadernos de Saúde Pública, Rio de Janeiro, 30 dez. 2007. Disponível em: www.scielo.br/pdf/csp/v23n12/21.pdf. Acesso em: 24 mar. de 2020 .

[15] CRESWELL, John W. Projeto de pesquisa: métodos qualitativo, quantitativo e misto. 2 ed. Tradução de Luciana de Oliveira da Rocha. Porto Alegre: Artmed, 2007, p.17-18.

[16] GONÇALVES, Dias Roberto. Boletim técnico cerâmica extrudada Gail. Destinatário: Lucimir Azevedo Monteiro Neto. [S.l], 14 abr. 2020. 1 mensagem eletrônica. 
[17] INSTITUTO DE ARQUITETURA E URBANISMO (Brasil). Guia Para Revestimentos Cerâmicos. São Carlos, SP. 2003. Disponível em: http://www.iau.usp.br. Acesso em: 25 mar. de 2020.

[18] INSTITUTO NACIONAL DE METROLOGIA, QUALIDADE E TECNOLOGIA (Brasil). Revestimentos Cerâmicos. Brasília, DF. 2012. Disponível em: http://www.inmetro.gov.br/consumidor/produtos/revestimentos.asp. Acesso em: 25 mar. de 2020.

[19] MATOS, Cristina Henschel de. Condições de trabalho e estado nutricional de operadores do setor de alimentação coletiva: um estudo de caso. 2000. 137f. Dissertação (Mestrado em Engenharia de Produção) - Programa de Pós-Graduação em Engenharia de Produção / Ergonomia, Universidade Federal de Santa Catarina, Florianópolis, 2000. Disponível

em: https://www.researchgate.net/profile/Rossana_Proenca/publication/26371332_Condicoes_de_trabalho_e_estado_nu tricional_de_operadores_do_setor_de_alimentacao_coletiva_um_estudo_de_caso/links/0deec521eeab74ad37000000/ Condicoes-de-trabalho-e-estado-nutricional-de-operadores-do-setor-de-alimentacao-coletiva-um-estudo-de-caso.pdf. Acesso em 24 mar de 2020.

[20] MEDEIROS, Jonas Silvestre; SABBATINI, Fernando Henrique. Tecnologia e projeto de revestimentos cerâmicos de fachadas de edifícios. Orientador: Alex Abiko. 1999.32 f. Tese (Doutorado em Engenharia de Construção Civil) - Escola Politécnica, Universidade de São Paulo, São Paulo, 1999.

[21] MONTEIRO, Renata Zambon; BRUNA, Gilda Collet. Projetos para atualização de espaços destinados a serviços profissionais de alimentação. 2004. 16f. Caderno (Pós-graduação em Arquitetura e Urbanismo) - Universidade Presbiteriana Mackenzie, São $\quad$ Paulo, 2004. http://editorarevistas.mackenzie.br/index.php/cpgau/article/view/5966. Acesso em 25 mar de 2020.

[22] MORAES, Silvana da Silva. Conceitos de metodologia de design aplicados ao projeto de produtos cerâmicos extrudados. Orientador: Orestes Estevam Alarcon. 2010. 167f. Dissertação (Mestrado em Ciência e Engenharia dos Materiais) - Universidade Federal de Santa Catarina, Florianópolis, 2010.

[23] OLIVEIRA, Antonio Pedro Novaes de; HOTZA, Dachamir. Tecnologia de fabricação de revestimentos cerâmicos. 2 ed. Florianópolis: Ed. da UFSC, 2015, p. 64-91.

[24] TRIBUNAL DE CONTAS DA UNIÃO, Orientações para elaboração de planilhas orçamentárias de obras públicas. Brasília: TCU, 2014. 


\section{Capítulo 7}

\section{Desenvolvimento experimental do concreto permeável}

com seixo

\section{Elane Batista de Almeida \\ Elissandra Barata da Silva \\ Luciane Farias Ribas}

Sara Santarém

Resumo: Atualmente um dos impactos gerados pela ocupação urbana desordenada, impermeabilização do solo e aumento das águas superficiais, tem sido uma das causas das inundações. Entre as soluções para minimização desses impactos é o uso dos pavimentos permeáveis que drenam as águas superficiais retornando para os aquíferos e mananciais. A reposição do volume de água para esses reservatórios garante o equilíbrio no ciclo hidrológico. Porém, para a viabilidade técnica e econômica desses pavimentos em concreto permeável é necessário usar os materiais disponíveis na região. Por isso, o presente trabalho tem por finalidade estudar o desenvolvimento experimental das propriedades físicas e mecânicas do concreto permeável utilizando como agregado graúdo o seixo rolado da região amazônica. Com o traço ajustado as características dos materiais locais, as propriedades mecânicas e físicas foram determinadas e avaliadas para classificar o concreto desenvolvido como permeável. Para a realização dos ensaios foram feitos dois tipos de traços, o traço com argamassa (T1) e o traço com pasta (T2). Ensaios de Resistência à compressão, absorção, índice de vazios, massa específica e permeabilidade foram realizados para os dois traços. 0 traço que superou os parâmetros mínimos do concreto permeável em seus resultados foi o traço (T2) com pasta, apresentando valores de resistência à compressão simples de 10,83 $\mathrm{MPa}$ aos 28 dias, índice de vazios de 25,33\% e coeficiente de permeabilidade. 0 único dado maior que (T1) teve foi no índice de vazios com $27 \%$, porém devido a areia ter mais porosidade porem diminui-se a resistência.

Palavras chave: Concreto permeável, resistência à compressão e permeabilidade. 


\section{INTRODUÇÃO}

O concreto permeável é uma tecnologia em desenvolvimento que tem a finalidade de diminuir esse problema urbano, permitindo a passagem da água através de seus poros. Para o desenvolvimento do concreto permeável de acordo com a NBR 16.416 (ABNT, 2015) foi realizado um estudo da dosagem. Com o traço ajustado as características dos materiais locais, as propriedades mecânicas e físicas foram determinadas e avaliadas para classificar o concreto desenvolvido como permeável.

Para a realização dos ensaios foram feitos dois tipos de traços, o traço com argamassa (T1) e o traço com pasta (T2). Ensaios de Resistência à compressão, absorção, índice de vazios, massa específica e permeabilidade, foram realizados para os dois traços, ao final comparar os resultados que mais atendesse os requisitos exigidos pela norma.

\section{FUNDAMENTAÇÃO TEÓRICA}

\subsection{CAUSAS E CONSEQUÊNCIAS DO CRESCIMENTO DESORDENADO DAS CIDADES}

Para garantir sua subsistência e segurança, as civilizações vem interferindo na natureza, ocasionando diversos impactos ao meio ambiente, em grande ou pequena escala, trazendo à tona uma diversidade de problemas (HOLTZ, 2011). Com essa expansão demográfica, aumenta as superfícies impermeáveis, tornando um dos principais impactos nos processos hidrológicos (POLASTRE; SANTOS, 2006). Para recuperar a capacidade de infiltração do solo, o concreto permeável é uma das opções, beneficiando ao meio ambiente e economicamente. (PALASTRE; SANTOS, 2006).

\subsubsection{MUNDO}

Os primeiros países que aplicaram em construção de pavimento o concreto permeável, como alternativa capaz de infiltrar a água sem que apresentasse problemas técnicos, foi o Estados Unidos da América, França, Japão e Suécia (CURVO, 2017 p7). Para melhor compreendimento dessa aplicação, foi realizada nos Estados Unidos da América, vários experimentos em seis estacionamentos, onde se destacou o estacionamento do Campus da Iowa State University, a área foi dividida em revestimentos de concreto permeáveis e concreto convencionais (BATEZINI, 2013 p51).

Ao comparar os dois tipos de aplicação, observou-se que o pavimento impermeável apresentou aparência úmida, o pavimento permeável permaneceu com aparência inalterada, a Figura 1 adaptada pelo autor Batezini em 2013, mostra claramente a diferença entre as superfícies dos pavimentos após a ocorrência da precipitação.

Figura 1 - Diferença das superfícies dos pavimentos após a precipitação no estacionamento de Iowa

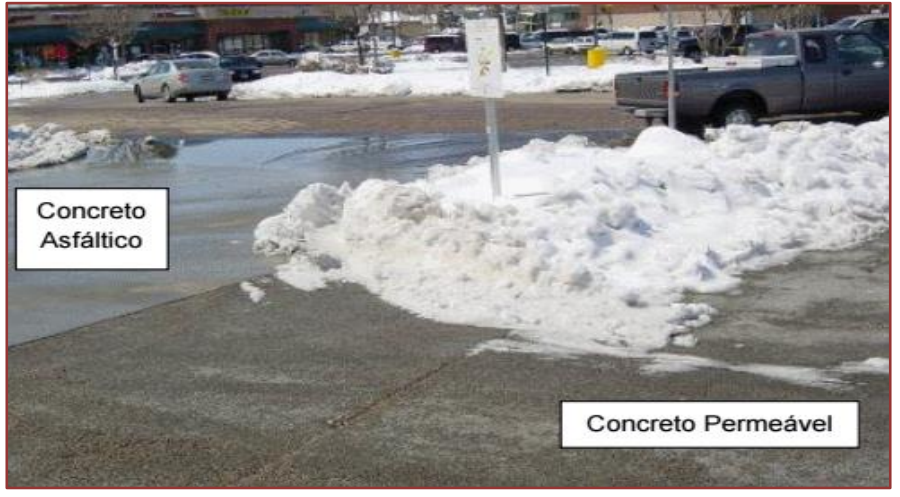

Fonte: Batezine adaptada (2013)

Segundo Batezini (2013), o estudo teve como finalidade comparar e avaliar a capacidade entre os pavimentos, resultando um aumento de temperatura durante o ciclo de aplicação de carga na estrutura interna do concreto permeável. 


\subsubsection{BRASIL}

Com o crescimento populacional desordenado das cidades, ocorreu a falta de planejamento urbano, trazendo várias consequências. Tais consequências são: o desmatamento, invasão em áreas de riscos, problemas de saneamento básico, poluição ambiental causados por acúmulos de lixos jogados em áreas impróprias, enchentes e inundações, por excesso de impermeabilização do solo e por drenagem insuficiente (TUCCI, 2005 p17; BOTELHO, 2014 p10). Essas áreas são afetadas principalmente nos períodos dos eventos hidrológicos (MILOGRANA, J. 2009 pg10).

Em áreas urbanas, as superfícies destinadas ao sistema viário e as de estacionamentos podem ocupar espaços consideráveis, chegando a 30\% da área da bacia de drenagem (VIRGILIIS, 2009 p29). Com isso dificultando a percolação da água até o lençol freático ou até um sistema de drenagem. De acordo com Araújo (2000 p21), um tipo de dispositivo utilizado para conter as áreas de inundações causado pela impermeabilização é o pavimento permeável, que é capaz de reduzir volumes de escoamento superficial e vazões de pico a níveis iguais ou até inferior aos observados antes da urbanização.

Um exemplo desse tipo de aplicação, foi na cidade de São Paulo em 2009, por meio da parceria da prefeitura e a universidade de São Paulo, desenvolveram o asfalto poroso permeável que permite que a água seja infiltrada e fique armazenada em uma camada de pedra abaixo da superfície em um estacionamento (VIRGILIIS, 2009 p96). Essa aplicação resultou grandes benefícios ambientais, segurança ao pedestre e vantagens econômicas.

\subsubsection{MANAUS}

Na Capital do Amazonas, Manaus, com uma população de cerca de 2.145.44 milhões de habitantes, teve um crescimento desordenado, trazendo consigo as ocupações irregulares e desprovidas de infraestruturas (IBGE, 2019). Na Figura 2 Zona Leste de Manaus mostra uma situação recorrente, a ocupação irregular em área de risco.

Com essa urbanização o processo de impermeabilização em Manaus não é diferente do resto do Brasil, grande parte das águas pluviais não infiltram, causando as inundações em várias áreas da cidade. Devido ao seu ciclo hidrológico, se torna importante ter soluções eficazes para suprir a necessidade desta questão, pois no período de inverno amazônico o volume de águas pluviais é significativo tornando se um problema visível (CPRM, 2008).

Em busca de soluções para este desequilíbrio, órgãos públicos têm adotado medidas que possam de alguma maneira diminuir os impactos causados pela ocupação urbana, partindo do princípio do escoamento das águas superficiais de forma rápida para jusante como mais importante "Impacto Zero" na gestão de drenagem urbana (PINTO, L.L.C.A 2011 pg12). Como podemos observar na Figura 3 na Zona Centro-Sul de Manaus, o excesso de impermeabilização do solo e a ineficiência de drenagem provocando inundações.

Figura 2 - Rua Bela Vista, na comunidade Nova Vitória, ocupações irregulares e desprovidos de infra-

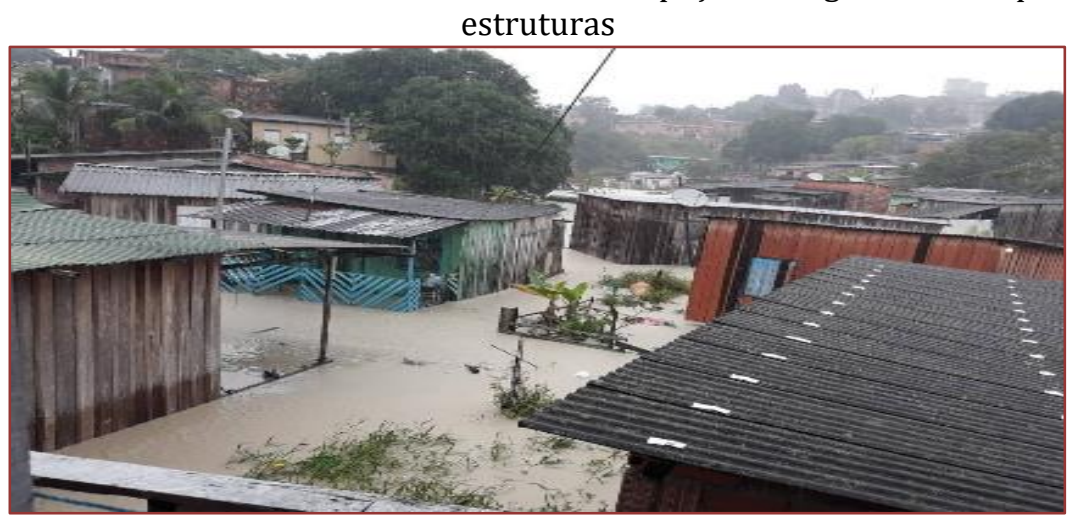


Figura 3 - Avenida Constantino Nery, alagada pelo excesso de impermeabilização do solo

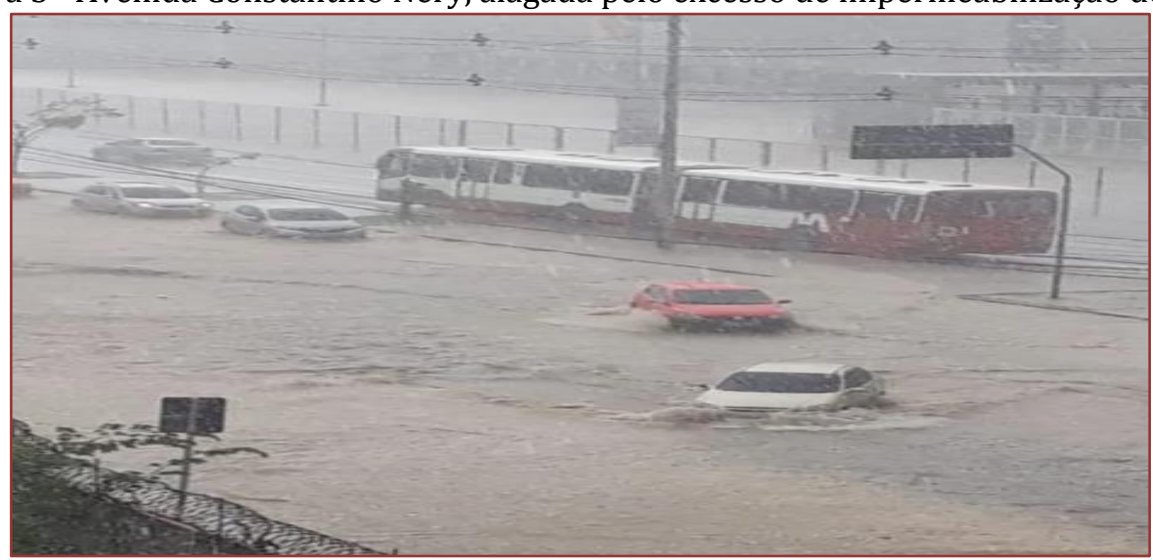

Fonte: g1.globo.com. (2018)

A compreensão e o monitoramento das mudanças na cobertura do solo amazonense ocasionadas pela urbanização desordenada são fundamentais para atividades de planejamentos urbano em Manaus (KUCK, 2011 p 0996).

A utilização do concreto permeável nessas áreas afetadas por excesso de impermeabilização é uma tecnologia viável que pode contribuir ao meio ambiente para selecionar os problemas ocorridos em lugares propícios de inundação, (YUKIO C et al., 2013, p.114).

\subsection{CONCRETO PERMEÁVEL}

\subsubsection{EVOLUÇÃO HISTÓRICA}

De acordo com Virgiliis (2009), a origem do concreto permeável surgiu nos anos 40 na França, pela necessidade que as cidades em crescimento tinham para se adequarem aos diferentes solos. Mas na época não tinha sido bem-sucedido esse tipo de material. Como os ligantes empregados na mistura da composição não eram bem estudados, até então a estrutura rompia-se pela baixa adesividade liganteagregado, não conferindo capacidade de carregamento ao revestimento permeável. Com passar dos anos, voltou o interesse no material do concreto permeável, nos países como Estados Unidos, Japão, Suécia, que voltaram a se interessar pelo método e aplicá-lo em pequena escala (AZZOUT et al., 1994).

O pavimento feito de concreto permeável destacou-se como uma das soluções, pela sua facilidade de integração com o meio ambiente urbano (Acioli, L.A. 2005 apud Azzout et al, 1994). Com passar dos anos Field et al., 1982, criaram manuais para práticas de projeto e construção de concreto permeável, a partir dos anos 1980 passou a ser produzido industrialmente, firmando-se como tecnologia em 1990 contra as enchentes (VIRGILIIS, 2009). Segundo Ghafoori (1995), nos Estados Unidos, um marco no uso de pavimento permeável como redutor dos impactos ambientais foi a pesquisa realizada no início da década de 70. 0 mesmo autor ressalta que Edmund Thelem e engenheiros do Instituto Frankin na Philadelphia que, com o apoio da U.S Enviromental Protection Agency (EPA), utilizando o concreto permeável para controle de cheias em 1968. Segundo Mulligan (2005), o concreto permeável começou a ser utilizado nos EUA, com a finalidade de incrementar a permeabilidade de zonas urbanizadas, nos Estados da Flórida, Utah e Novo México.

De acordo com Mulligan (2005), os bons resultados obtidos fizeram com que a tecnologia rapidamente se espalhasse para outros Estados, tais como a Califónia, Illinois, Oklahoma e Winsconsin. 0 crescente interesse, resultou na disseminação de pequenos fornecedores do material e na fundação de uma associação, a NPCA (National Pervious Concrete Association). O American Concrete Institute (ACI) instituiu uma competição anual na qual estimula estudantes de graduação a produzir concretos permeáveis, simples ou com adição de fibras buscando disseminar a tecnologia (ACI, 2006).

Com passar dos anos, algumas áreas construídas com concreto permeável sofreram colmatação e consequentemente declive da taxa de infiltração. No entanto, recentemente com aplicação de novas tecnologias e materiais mais apropriados estão sendo desenvolvidas e estudadas concretos permeáveis com melhor desempenho hidráulico além de durabilidade e confiabilidade na estrutura (LI, 2009). 


\subsubsection{PROPRIEDADES DO CONCRETO PERMEÁVEL}

O concreto permeável dependendo de sua composição e estrutura é caracterizado por apresentar alta porosidade e uma drenagem superficial. Pela facilidade de infiltração da água através de sua estrutura porosa, quando sua aplicação é feita corretamente, influência nas vazões de pico que ocorrem nos períodos de chuva, nas áreas que utilizam esses tipos de projeto de permeabilidade (BUTLER; DAVIES, 2004).

O concreto permeável é um material composto por aglomerante, sendo mais utilizado na sua composição a brita de granulação uniforme (ou seixo), água e nenhuma ou pouca quantidade de agregado miúdo. 0 concreto permeável apresenta um aumento de permeabilidade ao ser submetido a uma carga reduzida, é o mesmo material utilizado na produção do concreto convencional, com pequenas alterações na adição da mistura do agregado miúdo (SHI, 2018). Com isso ocorrerá a infiltração por meio dos poros, acelerando a drenagem da água pluvial.

Essa tecnologia comprova três tipos de procedimentos quanto à resistência e a drenagem superficial. Sobre este importante assunto, Dellate e Clearly (2019) afirmam quanto a resistência mecânica e a permeabilidade dos três tipos de concreto permeável estrutural no Quadro 1 abaixo.

Quadro 1 - Três procedimentos dos tipos de concreto permeável

\begin{tabular}{|c|c|c|c|}
\hline Concretomeável & Resistência Mecânica & $\begin{array}{c}\text { Permeabilidade e Índices de } \\
\text { vazios }\end{array}$ & Aplicação \\
\hline Hidráulico & Baixa & Grande & Não estrutural \\
\hline Normal & Média & Média & Tráfego leve \\
\hline Estrutural & Grande & Baixa & Tráfego médio \\
\hline
\end{tabular}

A mistura da composição do concreto permeável tem a finalidade de formar uma pasta para criar uma capa ao redor das partículas dos agregados, essa mistura é adicionada a água com o ligante hidráulico de forma cautelosa, (BATEZINI, 2013).

A composição do concreto permeável adquirida pelo experimento e a qualidade do processo realizado em laboratório pode variar a condutividade hidráulica, está entre 0,1 e $0,9 \mathrm{~cm} / \mathrm{s}$ conforme Delattle et al. (2019). Conforme a norma do American Concrete Institute (ACI, 2006), as misturas de concreto permeável normalmente tendem a desenvolver resistências de compressão na escala de 3,5 MPa a $28 \mathrm{Mpa}$.

De acordo com Batezini (2013), para melhores resultados do concreto permeável, é necessário realizar em laboratório os experimentos e procedimentos de misturas para encontrar a dosagem correta, e que acha uma disponibilidade de insumos no local dos testes. Um dos fatores que necessita de total observação devido a consistência é a relação do cimento/agregado, são os que podem afetar diretamente nas características mecânicas do material, através do procedimento de compactação ou adensamento (ACI, 2006).

\subsubsection{ADITIVOS SUPERPLASTIFICANTES NA MISTURA DO AGLOMERANTE LIGANTE HIDRAÚLICO}

Os aditivos superplastificantes podem ser necessários para o tempo de pega das misturas, com grande função de melhorar a característica de trabalhabilidade. Para produzir o concreto permeável é necessário que contenha o aglomerante ligante hidráulico principal, o cimento Portland. Entretanto, cabe ressaltar que na aplicação de aditivos, tem que ser supervisionados para garantir os índices de vazios e boa condutividade hidráulica, para que o concreto não perca sua característica drenante. Os aditivos químicos são também incorporados na mistura do concreto permeável, assim como na composição do concreto do cimento Portland convencional, ajudam no tempo de pega ligeiramente, outro aditivo é os redutores de água são utilizados dependendo na relação água/cimento (PERVIOUS PAVEMENT, 2011).

Na maioria dos casos, os aditivos não representam um custo adicional, pois a sua utilização resulta em economia, como redução do custo do trabalho para adensamento, redução do teor de cimento, aumento da durabilidade. São formas de economizar que, com ajustes no traço após a implantação de aditivos, são vistas rapidamente (NEVILLE, 1997, p.251). 


\subsubsection{CONCRETO PERMEÁVEL X CONCRETO CONVENCIONAL}

O concreto permeável em relação com o processo do concreto convencional estando em estado fresco, após a mistura, apresenta uma característica de baixa trabalhabilidade, chegando a $20 \mathrm{~mm}$ o abatimento (ACI, 2006). Não é muito utilizado o ensaio de batimento de tronco de cone na execução do procedimento de misturas do concreto permeável, devido da sua baixa consistência, é mais utilizado o ensaio de massa unitária e o controle visual para acompanhar mais a estabilidade que vai apresentar a mistura. Sendo que a massa unitária do concreto permeável representa $70 \%$ da massa unitária do concreto convencional (PERVIOUS CRONCRETE PAVIMENT, 2011). Geralmente o concreto permeável tem um tempo menor para o preparo, que ao tempo do concreto convencional. Em uso de aditivos retardadores deve se esperar 90 minutos, caso o material seja misturado somente com água deve aguardar 60 minutos, (ACI, 2006). Isso vai de acordo com o tipo de aditivo que será usado, também em relação ao ambiente.

A diferença da textura do concreto convencional para o concreto permeável é a superficialidade. Por sua estrutura não conter agregados miúdos na sua composição, tem uma superfície rugosa, aumentando o coeficiente de atrito (BATEZINI, 2013). De acordo com Tennis et al (2004) as massas especificas do concreto permeável no estado fresco variam de 1.200 a $2.000 \mathrm{~kg} / \mathrm{m}^{3}$. 0 procedimento de compactação da mistura tem suas massas e índices de vazios variáveis em função relativa de seus materiais constituintes.

Tennis et al, (2004) afirma que os concreto permeável para revestimento de pavimento, os valores típicos de condutividade hidráulica é $0,21 \mathrm{~cm} / \mathrm{s}$ e $0,54 \mathrm{~cm} / \mathrm{s}$. 0 concreto permeável tem um dos parâmetros que é a taxa de percolação ou coeficiente de permeabilidade k, que pode ser definida pela taxa de infiltração da água pluvial através de seu grande índice de vazio que sua estrutura lhe propôs (BATEZINI, 2013). Umas das propriedades fundamentais do concreto permeável é a trabalhabilidade. Porém, a trabalhabilidade depende das características e do tipo de cimento, da forma e natureza dos agregados, da quantidade de água e do traço do concreto (MARTIN,2005, p. 385-387).

\section{MATERIAIS E MÉTODOS}

Para melhor entendimento, organizou-se um Fluxograma de 6 etapas, conforme ilustra a Figura 5.

Figura 5- Fluxograma dos procedimentos experimentais

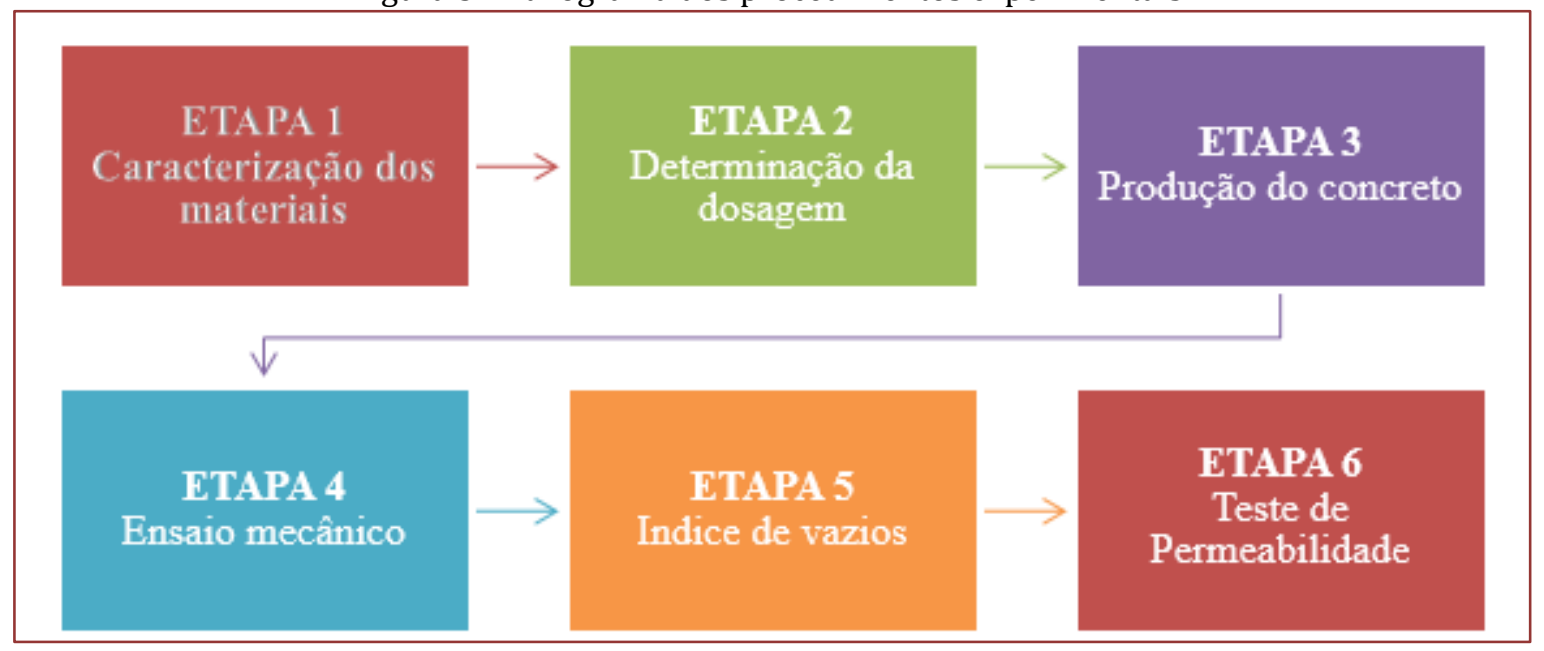

Fonte: Autoria Própria (2019)

\subsection{MATERIAIS}

\subsection{1 ÁGUA}

Água utilizada foi à fornecida pela rede de distribuição da Águas de Manaus, provenientes da ETA que atende a população local. 


\subsubsection{ADITIVO}

\subsubsection{SUPERPLASTIFICANTE POLICARBOXILATO - PC}

0 aditivo usado para compor na mistura foi da marca GCP Applied Technologies, o produto ADVA ${ }^{\circledR}$.

\subsubsection{AGREGADO GRAÚDO}

Foi utilizado como agregado graúdo o seixo, disponível no Estado do Amazonas, é oriundo do leito do rio Juruá rio extraído por meio de dragas.

\subsubsection{AGREGADO MIÚDO}

O agregado miúdo utilizado foi areia classificada como de granulometria média para a dosagem do traço T1.

\subsubsection{CIMENTO PORTLAND CP II F-32}

O aglomerante utilizado foi o Cimento Portland CP II F-32 da marca Poty, para utilização deste aglomerante, os resultados mais significativos serão aos 28 dias pelo seu ganho de resistência ser lento.

\subsection{MÉTODOS E EQUIPAMENTOS}

Para avaliar as propriedades físicas e mecânicas do concreto permeável doistraços foram desenvolvidos, a dosagem denominada T1 e a dosagem denominada T2. A dosagem T1 corresponde ao traço com adição de areia. 0 traço da dosagem T2 corresponde ao concreto permeável sem adição de areia. Na Tabela 1 consta o consumo de materiais para a produção do concreto permeável T1.

Tabela 1 - Dosagem T1 - Consumo do concreto permeável com areia

\begin{tabular}{|l|c|}
\hline \multicolumn{2}{|c|}{ DOSAGEM EXPERIMENTAL T1 } \\
\hline Cimento Portland II F-32 & $380 \mathrm{~kg}$ \\
\hline Agregado miúdo & $356 \mathrm{~kg}$ \\
\hline Agregado graúdo (Seixo) & $1155 \mathrm{~kg}$ \\
\hline Água & $100 \mathrm{~L}$ \\
\hline Aditivo policarboxilato & $0,5 \%$ \\
\hline \multicolumn{2}{|c|}{ Fonte: Autoria Própria (2019) } \\
\hline
\end{tabular}

Buscou-se manter a mesma relação água cimento para que as propriedades fossem avaliadas eliminado o efeito da relação a/c. Na Tabela 2 consta o consumo de materiais para a produção do concreto permeável sem a adição de areia.

Tabela 2 - Dosagem T2 - Consumo do concreto permeável sem areia DOSAGEM EXPERIMENTAL T2

\begin{tabular}{|l|c|}
\hline Cimento Portland II F-32 & $374 \mathrm{~kg}$ \\
\hline Agregado miúdo & $0 \mathrm{~kg}$ \\
\hline Agregado graúdo (Seixo) & $1495 \mathrm{~kg}$ \\
\hline Água & $112,2 \mathrm{~L}$ \\
\hline Aditivo policarboxilato & $0,5 \%$ \\
\hline
\end{tabular}

Fonte: Autoria Própria (2019) 


\subsubsection{PRODUÇ̃̃O DO CONCRETO PERMEÁVEL}

Para a realização dos ensaios foram moldados corpos de prova cilíndricos de $10 \mathrm{~cm}$ x $20 \mathrm{~cm}$ e placas de $31,5 \mathrm{~cm} \times 31,5 \mathrm{~cm} \times 6,5 \mathrm{~cm}$. As placas de concreto foram determinadas pelo processo de vibração para o adensamento do concreto. 0 tempo de adensamento foi de 1 minuto, somente para tirar os agregados da inércia.

Realizada a moldagem os corpos de prova foram separados de acordo com o traço utilizado. Após 24h, foram desmoldados e submersos em água para que houvesse a devida cura conforme a NBR 5738 (ABNT, 2015), e que todas as amostras ficassem submersas em água saturada com cal.

\subsubsection{DETERMINAÇÃO DA RESISTÊNCIA A COMPRESSÃO}

A resistência à compressão do Concreto Permeável de Cimento Portland foi determinada conforme a NBR 5739 (ABNT, 2007), a prensa usada foi da marca EMIC de capacidade de 200 t. Os pratos da máquina e as faces dos CP's foram limpos e secos, centralizando os CP's na máquina, para um carregamento constante de velocidade de ensaio do equipamento $(0,45 \pm 0,15)(\mathrm{MPa} / \mathrm{s})$ até o seu rompimento.

Figura 7 - Corpo de prova devidamente posicionado para o ensaio de compressão

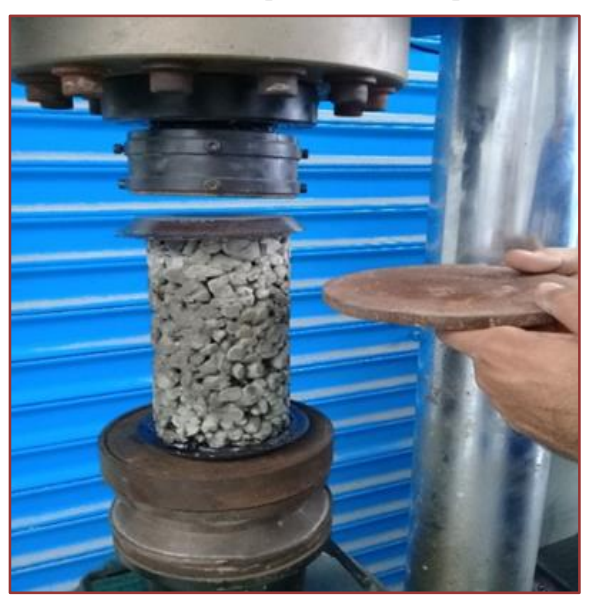

Fonte: Autoria Própria (2019)

\subsubsection{PROPRIEDADES FÍSICAS}

\subsubsection{ABSORÇÃO, ÍNDICE DE VAZIOS E MASSA ESPECÍFICA}

As propriedades físicas estudadas foram as estabelecidas pela NBR 9778 (ABNT, 2015). Para determinação do índice de vazios as amostras permaneceram na estufa a $105 \pm 5^{\circ} \mathrm{C}$ por um período de 72horas.

Figura 8 - Amostra na estufa e pesagem

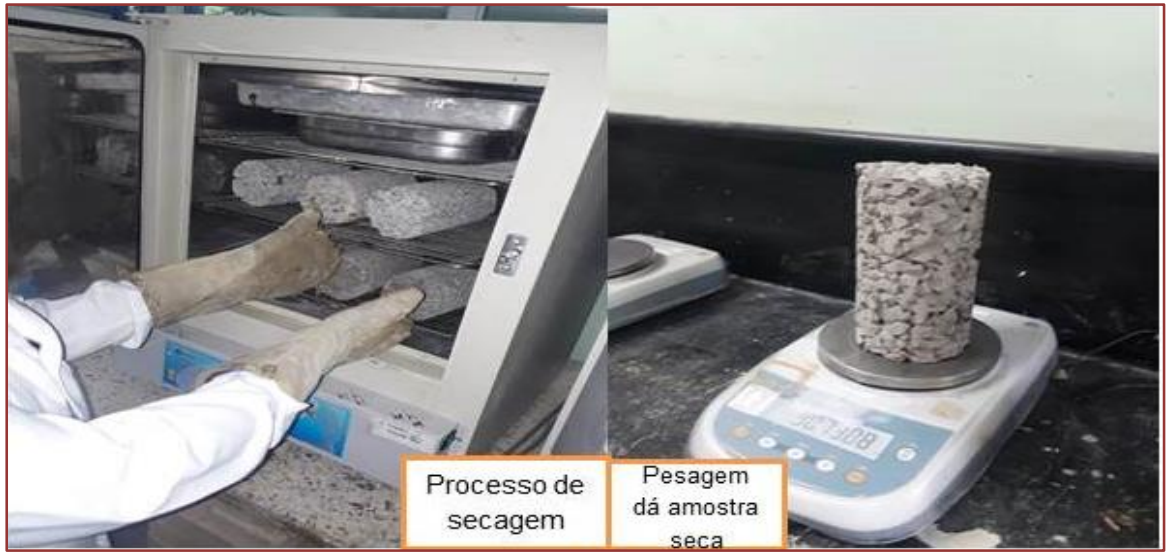

Fonte: Autoria Própria (2019) 


\subsubsection{PERMEABILIDADE}

Para a determinação da vazão das amostras, foi feita a relação entre o volume de água que passa pelo corpo de prova por um determinado período, de tempo. Além da determinação da vazão, foi feito cálculo do coeficiente de permeabilidade $(\mathrm{k})$, para que assim se pudesse fazer a comparação de acordo com a NBR 16416 (ABNT, 2015).

Figura 10- Placas T2 e T1 para testes de permeabilidade

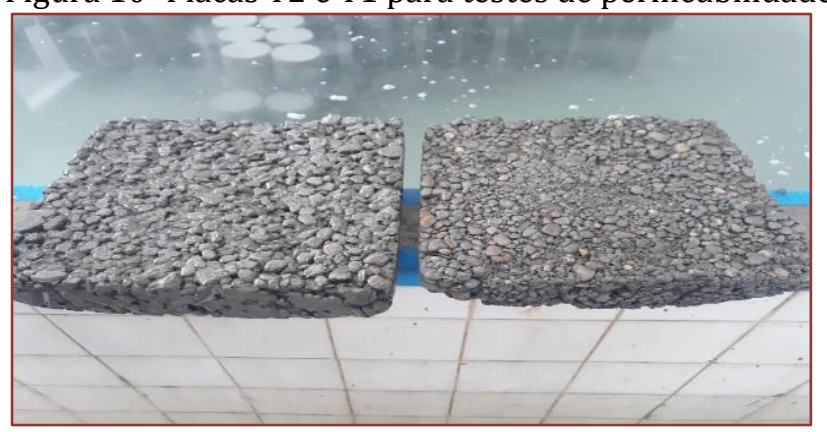

Fonte: Autoria Própria (2019

\section{RESULTADOS}

\subsection{ESTUDO DE DOSAGEM}

Os resultados granulométricos do seixo e areia. 0 gráfico 1 apresenta a distribuição da granulometria do agregado graúdo utilizado no traço T2 e o gráfico2 apresenta a distribuição da granulometria do agregado miúdo no traço T1.

Gráfico 1 - Distribuição granulométrica do seixo

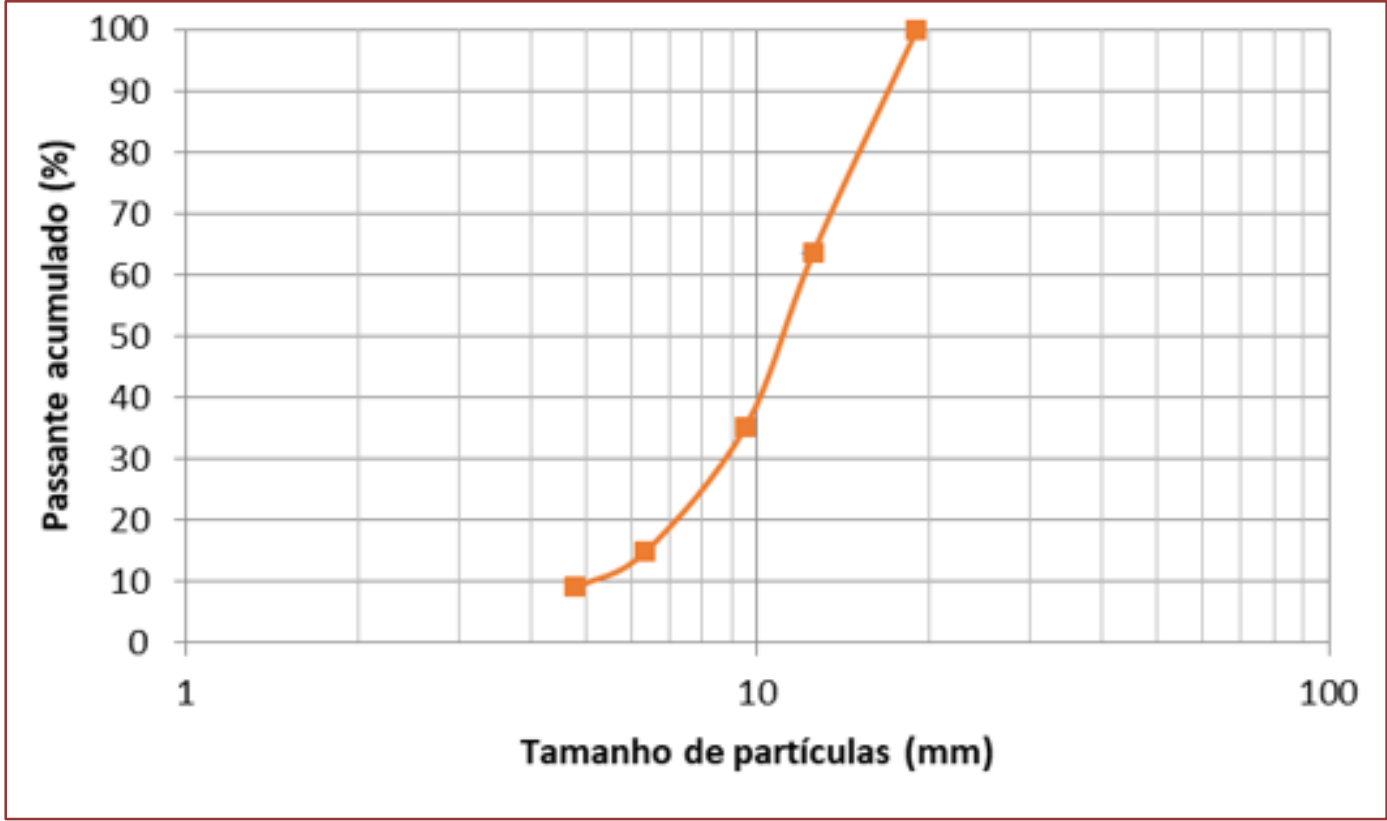

Fonte: Autoria Própria (2019) 
Gráfico 2 - Distribuição granulométrica da areia fina Fonte: Autoria Própria (2019)

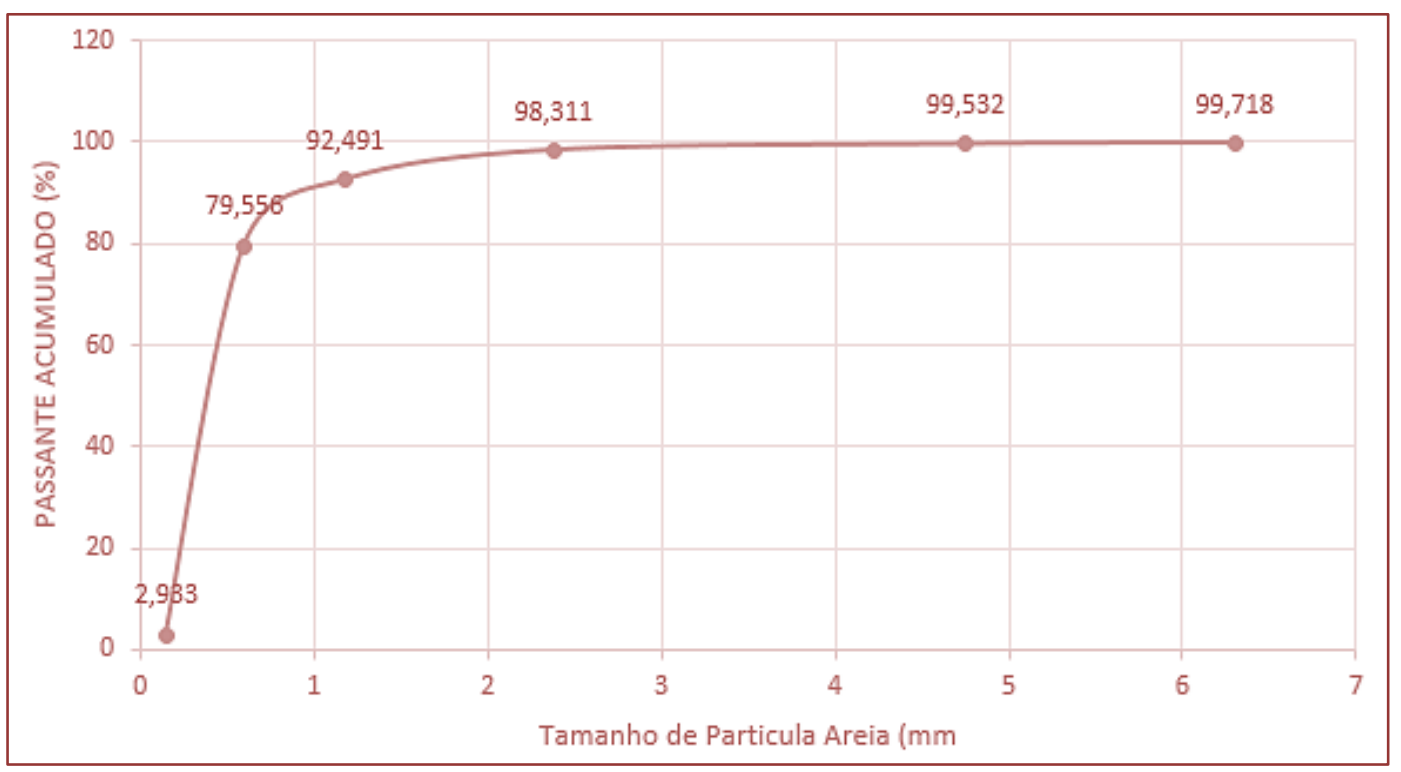

\subsection{RESISTÊNCIA À COMPRESSÃO}

Os valores obtidos estão coerentes com os valores na literatura de acordo com norma American Concrete institute (ACI, 2006), as misturas do concreto permeável tendem a desenvolver resistências de compressão na escala de entre 3,5 MPa e $28 \mathrm{MPa}$.

A evolução da resistência à compressão dos concretos permeáveis T1 Com Argamassa e T2 com Pasta pode ser observada no gráfico 3. Observou-se uma diferença nos rompimentos dos concretos T1 com Argamassa e T2 com Pasta. 0 T1 apresentou menor resistência em relação ao T2 com pasta chegando a 10,83 MPa em 28 dias.

Gráfico 3 - Evolução de resistência em 28 dias T1 com argamassa e T2 com Pasta

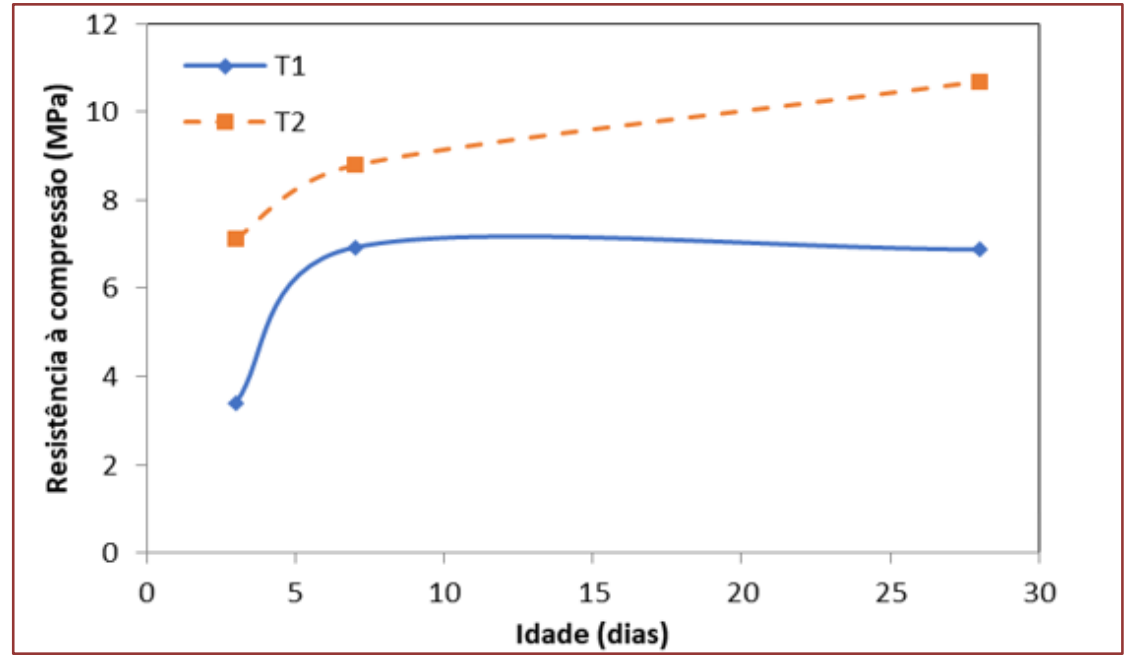

Fonte: Autoria Própria (2019)

A Tabela 3 consta a ANOVA dos dados de resistência a compressão aos 28 dias, e o valor-p é menor que o nível de significância $(\alpha=0,05)$, indica que a resistência à compressão aos 28 dias dos concretos T1 e T2 são significativamente diferentes.

Portanto pode-se dizer que a resistência a compressão de T2 com pasta foi maior que T1. 
Tabela 3 - ANOVA dos dados de resistência à compressão aos 28 dias dos concretos T1 e T2

\begin{tabular}{|c|c|c|c|c|c|c|}
\hline Fonte da variação & SQ & Gl & MQ F crítico \\
\hline Entre grupos & 32.258 & 1 & 32.258 & 10.20379944 & 0.01518479 & 5.591447851 \\
\hline Dentro dos grupos & 22.1296 & 7 & 3.161371429 & & & \\
\hline Total & 54.3876 & 8 & & & \\
\hline \multicolumn{7}{|c|}{ Fonte: Autoria Própria (2019) }
\end{tabular}

\subsection{ABSORÇÃo}

Para os ensaios de propriedades físicas foram aplicados nas equações da NBR 9778 (ABNT, 2015) os dados de peso seco, peso úmido e imerso para obter absorção, índice de vazios e massa especifica. Os valores de absorção para os concretos T1 com argamassa e T2 com pasta constam no gráfico 4.

Gráfico 4 - Absorção

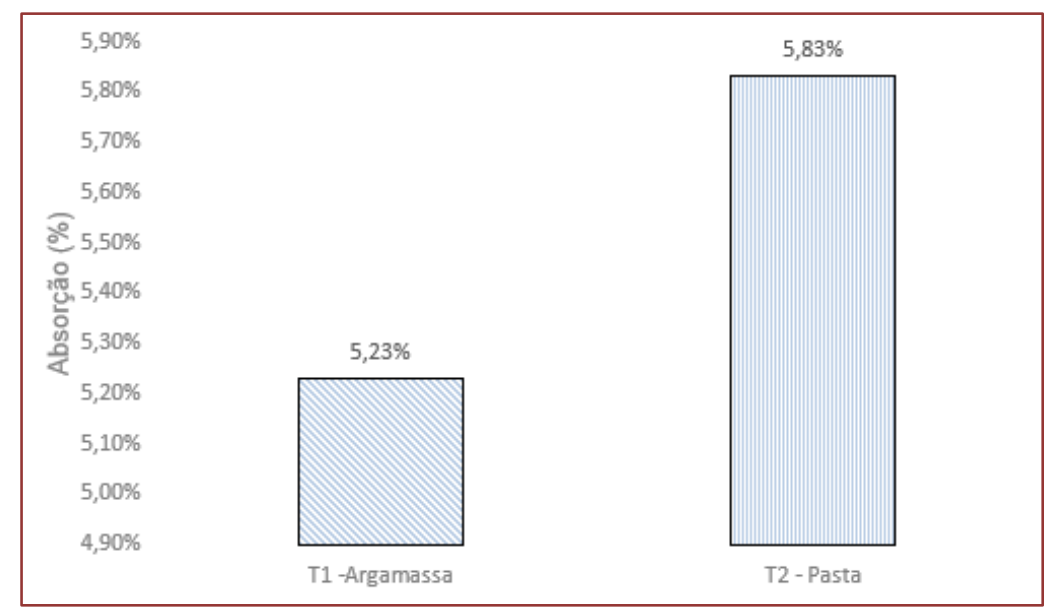

Fonte: Autoria Própria (2019)

Observou-se que a absorção no traço T2 foi superior ao T1 com uma diferença de apenas $0,6 \%$ de Absorção. A Tabela 4 apresenta a ANOVA dos dados de absorção, e observa-se que sendo o valor de $p$ inferior a 0.05 pode-se dizer que as médias dos valores de absorção são significativamente diferentes. Com isso podemos dizer que T2 com Pasta tem maior absorção que T1 com Argamassa.

Tabela 4 - ANOVA dados de absorção dos concretos T1 e T2

\begin{tabular}{|c|c|c|c|c|c|c|} 
Fonte da variação & SQ & MQ & F & valor-P & F crítico \\
\hline Entre grupos & 0.000057245 & 1 & $5.72 \mathrm{E}-05$ & 11.84584 & 0.013771 & 5.987378 \\
\hline Dentro dos grupos & 0.000028995 & 6 & $4.83 \mathrm{E}-06$ & & & \\
\hline Total & 0.00008624 & 7 & & & & \\
\hline \multicolumn{7}{c|}{ Fonte: Autoria Própria (2019) }
\end{tabular}

\section{4 ÍNDICES DE VAZIOS}

No Gráfico 5, estão representados os valores médios obtidos para o índice de vazios dos corpos de provas. Os resultados para o traço T1 e T2 estão acima da faixa conforme (BATEZINE, 2013). 0 traço T1 apresenta valor maior da faixa pré-determinada, que é de 0,15 a 0,3 . 
Gráfico 5 - Índice de vazios

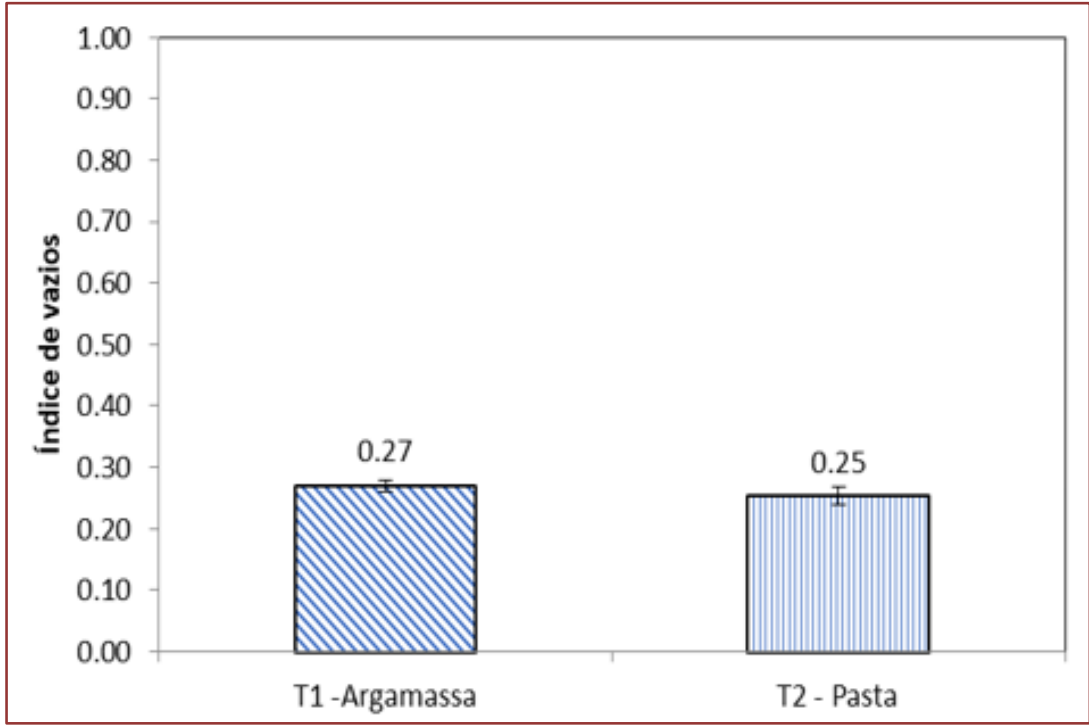

Fonte: Autoria Própria (2019)

Pode ser verificado, através da Tabela 5 , a comparação dos resultados resistência à compressão e do índice de vazios que quanto menor a porcentagem de índice de vazios maior e a resistência e a compactação com energia normal diminui este valor.

Porém os dois traços alcançaram os índices de vazios superiores da faixa, entretanto o T1 com argamassa apresentou $2 \%$ a mais pela adição do agregado miúdo.

Tabela 5 - ANOVA dos dados de índice de vazios dos concretos T1 com argamassa e T2 com Pasta

\begin{tabular}{|c|c|c|c|c|c|c|}
\hline \multicolumn{2}{c|}{ Fonte da variação } & \multicolumn{2}{c}{ SQ } & \multicolumn{2}{c}{ Gl } & \multicolumn{2}{c|}{$F$} & \multicolumn{2}{c|}{ valor-P } & F crítico \\
\hline Entre grupos & 0.000556111 & 1 & 0.000556111 & 5.004995 & 0.066604 & 5.987378 \\
\hline Dentro dos grupos & 0.000666668 & 6 & 0.000111111 & & & \\
\hline Total & 0.001222779 & 7 & & & & \\
\hline
\end{tabular}

Fonte: Autoria Própria (2019)

De acordo com a ANOVA o p-valor é maior que 0,05, isso significa que os valores de índice de vazio dos concretos T1 com argamassa e T2 com pasta não são significativamente diferentes.

\subsection{MASSA ESPECIFICA}

No Gráfico 6 da massa específica pode-se observar que o T1 com argamassa tem sua massa específica superior do T2 com pasta. 
Gráfico 6 - Determinação da massa especifica T1 com Argamassa superior a T2 com pasta

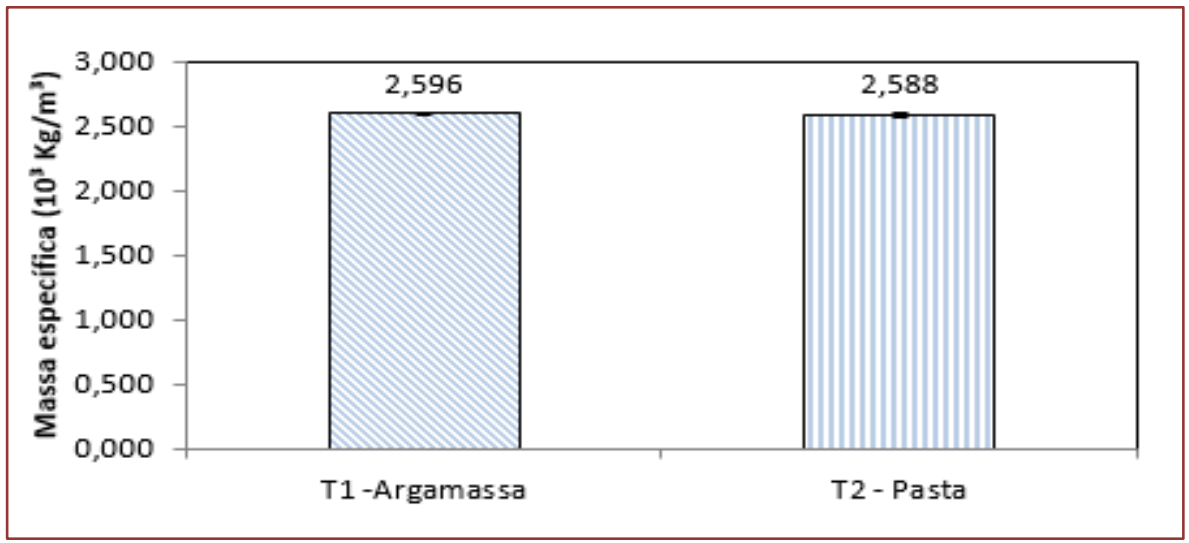

Fonte: Autoria Própria (2019)

Porém, na Tabela 6, observa-se que o valor-p é maior que 0,05 , isso significa que não há diferença significativa entre as massas específicas dos concretos T1e T2. Por tanto podemos dizer que a quantidade de areia adicionada no concreto permeável não alterou a sua massa especifica.

Tabela 5- ANOVA dados de massa específica dos concretos T1 e T2

\begin{tabular}{|c|c|c|c|c|c|c|c|c|}
\hline Fonte da variação & SQ & Valor-P & F crítico \\
\hline Entre grupos & $2.81667 \mathrm{E}-05$ & 1 & $2.82 \mathrm{E}-05$ & 0.282609 & 0.623149 & 7.708647 & \\
\hline Dentro dos grupos & 0.000398667 & 4 & $9.97 \mathrm{E}-05$ & & & & \\
\hline & & & & & & & \\
\hline Total & 0.000426833 & 5 & & & & & \\
\hline \multicolumn{7}{|c|}{ Fonte: Autoria Própria (2019) }
\end{tabular}

\subsection{PERMEABILIDADE}

A determinação da permeabilidade, realizou-se uma análise com relação, entre o coeficiente de permeabilidade $\mathrm{k}$, utilizando os dados de vazão das placas e dos cilindros. Os ensaios de placas foram verificados melhores desempenhos em relação ao tempo de percolação da água através de seus poros, o T1 apresentou melhor tempo e vazão, porém baixa resistência.

As placas no Gráfico 7 mostra o melhor desempenho de permeabilidade, resultando o T1 com melhor vazão durante os testes.

Gráfico 7 - Resultados encontrados para vazão em placa (l/s)

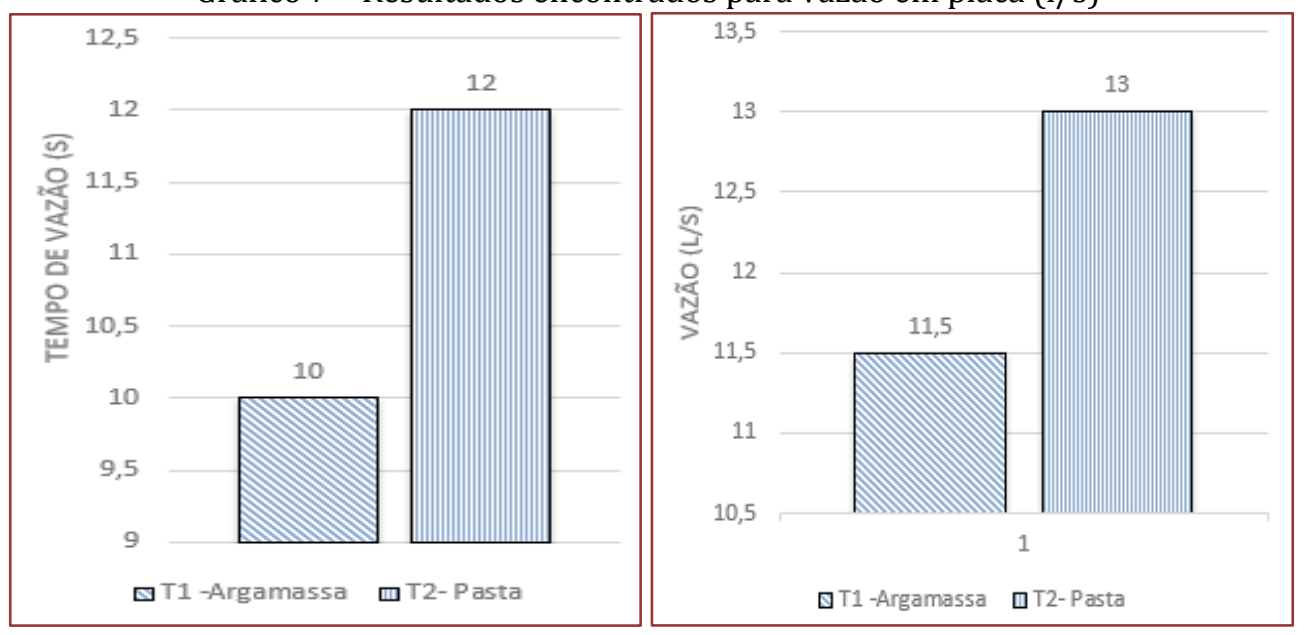


Através da equação de coeficiente de permeabilidade da NBR 16416 (ABNT,2015), encontrou-se o coeficiente de permeabilidade das placas, a Tabela 7 mostra o melhor desempenho para T1 com argamassa.

Tabela 7 - Resultados obtidos do coeficiente de permeabilidade da placa

\begin{tabular}{|c|c|}
\hline $\mathrm{T} 1$-Argamassa m/s & $\mathrm{T} 2-$ Pasta $\mathrm{m} / \mathrm{s}$ \\
\hline 0,017 & 0,011 \\
\hline Fonte: Autoria Própria (2019)
\end{tabular}

As placas na Figura 8 de melhor desempenho do coeficiente de permeabilidade k é do T1 com melhor resultado (sem adensamento), porém com baixa resistência e baixo coeficiente hidráulica.

Figura 8 - Determinação do coeficiente de prmeabilidade k em placa

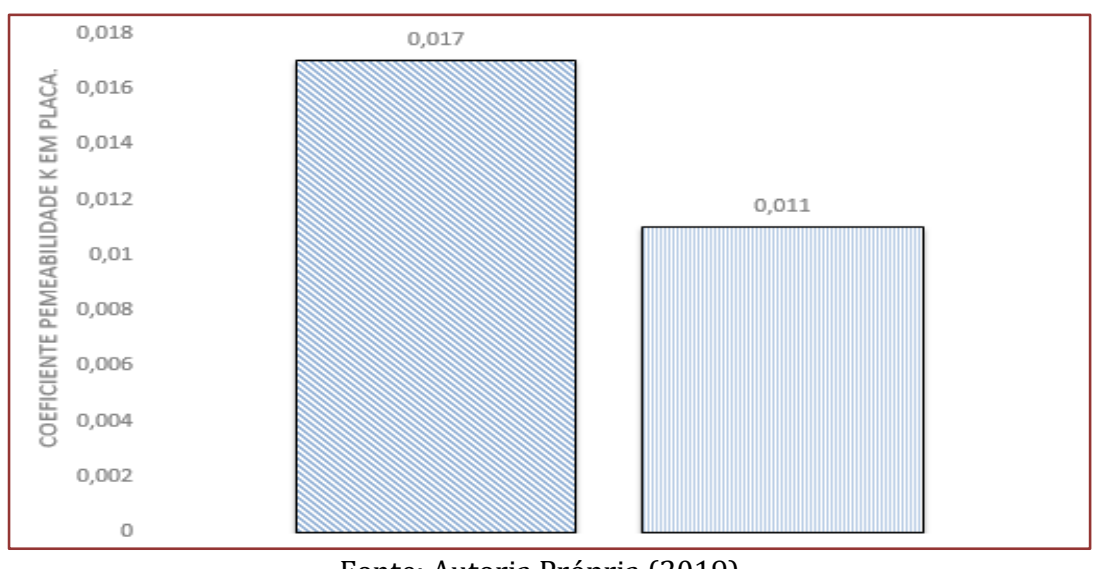

Na Tabela 8 estão os resultados obtidos através do estudo empírico de permeabilidade, que terminou a vazão pelo volume de água e o tempo de percolação no corpo de prova.

Tabela 8 - Vazão em corpos de provas de $10 \mathrm{~cm}$ de comprimento por $20 \mathrm{~cm}$ de altura

\begin{tabular}{|l|c|c|}
\hline \multirow{3}{*}{ Corpo de Prova } & T1 com Argamassa & T2 com Pasta \\
\cline { 2 - 3 } Tempo (s) & 31,6 & 35,0 \\
\cline { 2 - 3 } & 26,0 & 38,01 \\
\hline Tempo média (s) & 41,0 & 24,00 \\
\hline Volume (l) & 32,8 & 32,34 \\
\hline Vazão (l/s) & 2 & 2 \\
\hline \multicolumn{2}{|c|}{ Fonte: Autoria Própria (2019) }
\end{tabular}

Usando o mesmo método da NBR 16416 (ABNT,2015) para coeficiente de permeabilidade usados nas placas, e quantitativo de água percolada foram encontrados os resultados para coeficiente de permeabilidade em análise para os corpos de provas.

Tabela 9 - Coeficiente de permeabilidade em corpos de prova de $10 \mathrm{~cm}$ de comprimento por $20 \mathrm{~cm} \mathrm{de}$ altura.

\begin{tabular}{|c|c|c|}
\multicolumn{3}{|c|}{ Coeficiente de permeabilidade $>0,001$ conforme a NBR16416 (ABNT, 20015) } \\
Número de corpos de prova & T1 Com Argamassa & T2 Com Pasta \\
\hline 1 & $0,0115 \mathrm{~m} / \mathrm{s}$ & $0,0117 \mathrm{~m} / \mathrm{s}$ \\
\hline 2 & $0,0152 \mathrm{~m} / \mathrm{s}$ & $0,0109 \mathrm{~m} / \mathrm{s}$ \\
\hline 3 & $0,0098 \mathrm{~m} / \mathrm{s}$ & $0,0168 \mathrm{~m} / \mathrm{s}$ \\
\hline
\end{tabular}

Fonte: Autoria Própria (2019) 
A Figura 9 apresenta os resultados dos coeficientes de permeabilidade em corpos de provas cilíndricos expressos em média aritméticas.

Figura 9 - Coeficiente de permeabilidade em corpos de prova.

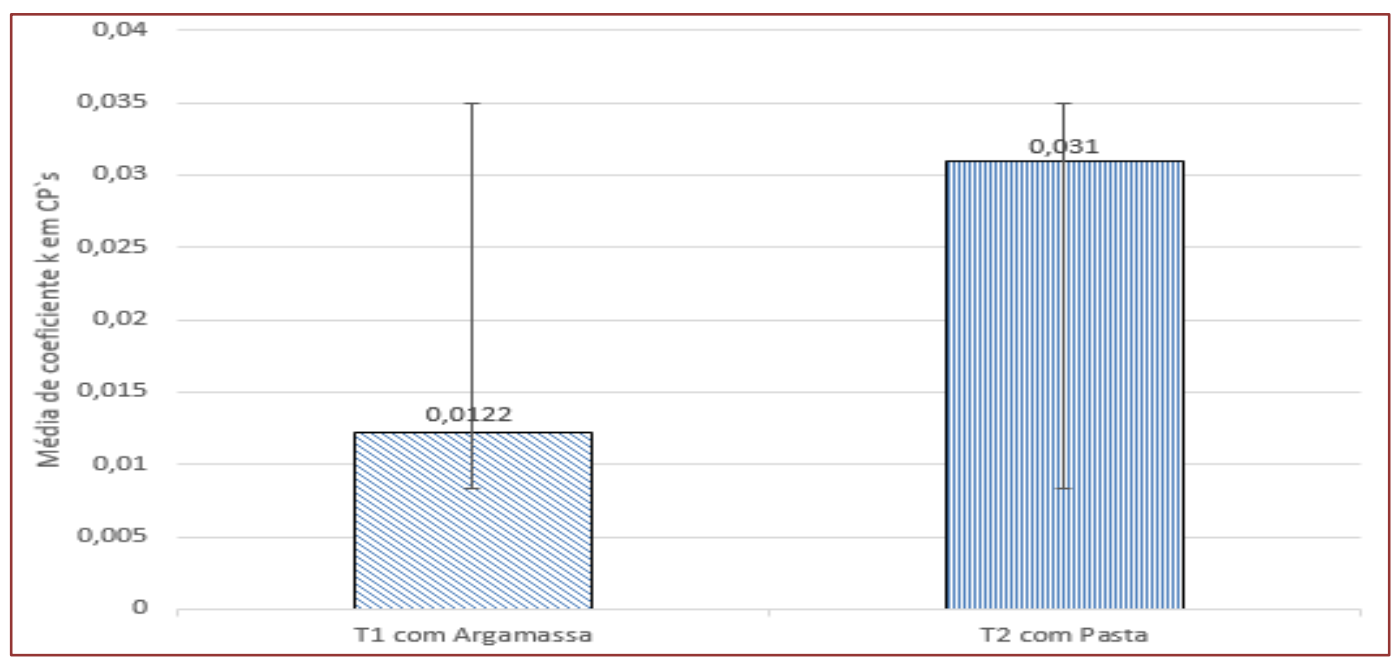

Fonte: Autoria Própria (2019)

De acordo com a norma NBR16416 (ABNT, 2015) o coeficiente de permeabilidade $\mathrm{k}$ em $\mathrm{m} / \mathrm{s}$ tem que ser > 0,001, então os resultados T1 com argamassa e T2 com pasta das amostras cilíndricas atenderam a norma.

Com base nos resultados obtidos nos ensaios, pode ser feita a verificação de que quanto maior a compactado menor é o coeficiente de permeabilidade, e é maior resistência, pois o adensamento por meio de vibração adquire maiores resistência com permeabilidade em comparação aos corpos de prova que não foram adensados.

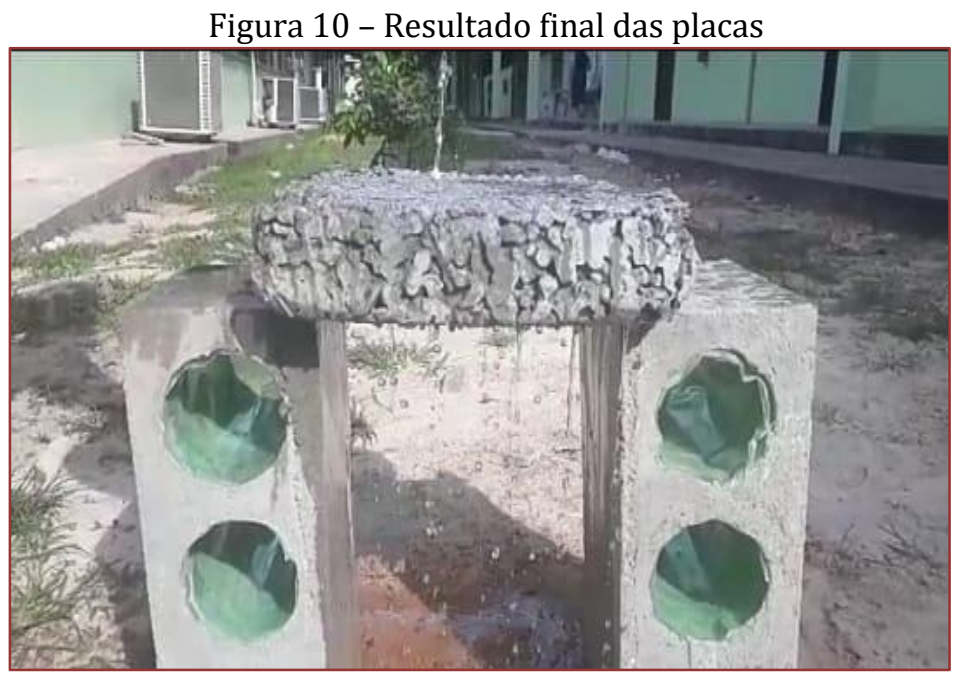

Fonte: Autoria Própria (2019)

A Tabela 9 os melhores resultados finais do desenvolvimento experimental do concreto permeável com seixo. 
Tabela 9 - Melhores resultados para ensaios mecânicos e condutividade hidráulica.

\begin{tabular}{|c|c|c|c|c|c|c|c|c|}
\hline $\begin{array}{c}\text { Ensaios } \\
\text { MECÂNICOS }\end{array}$ & \multicolumn{8}{|c|}{ RESISTÊNCIA A COMPRESSÃO FINAL } \\
\hline Traços & \multicolumn{4}{|c|}{$\begin{array}{c}\mathrm{T} 1 \text { - argamassa } \\
8.55 \mathrm{MPa}\end{array}$} & \multicolumn{4}{|c|}{$\begin{array}{l}\text { T2- Pasta } \\
10.83 \mathrm{Mpa}\end{array}$} \\
\hline \multirow{3}{*}{$\begin{array}{l}\text { ENSAIOS } \\
\text { FÍSICOS }\end{array}$} & \multicolumn{2}{|c|}{ ABSORÇÃO } & \multicolumn{2}{|c|}{$\begin{array}{l}\text { ÍNDICE DE } \\
\text { VAZIOS }\end{array}$} & \multicolumn{2}{|c|}{ MASSA ESPECIFICA } & \multicolumn{2}{|c|}{$\begin{array}{l}\text { PERMEABILIDADE k } \\
\text { (placas) }\end{array}$} \\
\hline & $\mathrm{T} 1$ & $\mathrm{~T} 2$ & $\mathrm{~T} 1$ & $\mathrm{~T} 2$ & $\mathrm{~T} 1$ & $\mathrm{~T} 2$ & $\mathrm{~T} 1$ & $\mathrm{~T} 2$ \\
\hline & $5,23 \%$ & $5,83 \%$ & $27 \%$ & $25 \%$ & 2,596 & 2,588 & 0,017 & 0,011 \\
\hline
\end{tabular}

\section{CONSIDERAÇÕES FINAIS}

0 trabalho experimental realizado permitiu elaborar as seguintes conclusões principais:

Os testes realizados nos corpos de prova cilíndricos do concreto permeável são tipicamente variáveis para os traços da mistura com argamassa e pasta. Esta ocorrência se dá principalmente devido ao elevado índices de vazios característicos desse tipo de concreto, o que tende a aumentar a variedade dos resultados.

Pode-se notar que as duas misturas não apresentam variação considerável dos resultados para praticamente todos os parâmetros avaliados no presente estudo. Foi observado que as resistências à compressão para as misturas especificas estudadas estão dentro da faixa de resistências encontradas na revisão bibliográfica.

Observou-se que as dosagens se mostraram como um material drenante, apresentando condutividade hidráulica, compatível com as normas. Nesse caso nota-se, que pode incluir nas misturas de concreto permeável certa quantidade de agregado miúdo, assim diminuindo a quantidade de consumo de cimento, melhorando assim a sua resistência à compressão e durabilidade.

\section{REFERÊNCIAS}

[1] ___ ABNT NBR 16416 - Pavimentos Permeáveis de Concreto - Requisitos e Procedimentos, Rio de Janeiro, 2015.

[2] ___ ABNT NBR 5738 - Concreto — Procedimento para moldagem e cura de corpos de prova. 2 ed. Rio de Janeiro: ABNT 2015, 2015a. 9 p.

[3] ___ ABNT NBR 5739 - Concreto - Ensaio de compressão de corpos-de-prova cilíndricos. 2 ed. Rio de Janeiro: ABNT 2007, 2007. 9 p.

[4] ___ _ _ ABNT NBR 9778 - Argamassa e concreto endurecidos - Determinação da absorção de água por imersão índices de vazios e massa específica. Rio de Janeiro, 2015.Bibliografia Consultada

[5] ACI COMMIETTEE 522. Pervious Concrete (ACI 522R-06). Farmington Hills: American Concrete Institute, 2006.

[6] ACIOLI, L.A. Estudo experimental de pavimentos permeáveis para o controle do escoamento superficial na fonte. Porto Alegre, UFRGS: Instituto de Pesquisas - Hidráulicas. Março/2005. 162p.

[7] ARAÚJO, P. R., TUCCI, C. E. M., GOLDEFUM J. A. Avaliação da eficiência dos pavimentos permeáveis na redução do escoamento superficial. Instituto de Pesquisas Hidráulicas da UFRG. Porto Alegre, 2000.

[8] AZZOUT Y., BARRAUD, S., CRES, F. N., ALFAKIH, E.; Techniques Alternatives en Assainissement Puvial, Prais: Technique et Documentation 1994. Lavoisier, 372p.

[9] BATEZINI, R. Estudo preliminar de concretos permeáveis como revestimento de pavimentos para áreas de veículos leves. Dissertação (Mestrado em Engenharia de Transportes) - Departamento de Engenharia de Transportes, Escola Politécnica da Universidade de São Paulo, São Paulo, 2013. 133p.

[10] BOTELHO.M. Águas de chuva - Engenharia das águas pluviais nas cidades. São Paulo: Edgar Blucher, 2014. p $.18,20$.

[11] BUTLER, D.; DAVIES, J. W. Urbane Dranage. Londres: Spon Press, 2004. 543 p.

[12] COMPANHIA DE PESQUISA DE RECURSOS MINERAIS - Serviços Geológico do Brasil (CPRM). Gerenciamento da cheia de Manaus - eventos 2008, 2008. Disponível em <http:// www.cprm.gov.br/rehi/manaus/pdf/rel_final_2008.pdf>. Acessado em 14 de abril de 2019, às 15:32.

[13] CURVO, Felipe de Oliveira. Estudo de Drenabilidade de Calçadas Experimentais em Concreto Permeável no 
Campus Armando Salles de Oliveira da USP. versão corrigida - São Paulo, 2017. 105 p.

[14] DELlATE, N.; CLEORY, J. Developing a Structural Desing Method for Pervious Concret Pavement. Disponível em: http://www.nssga.org/aftre/Symposium/2019-04.pdf. ACESSO, 30 de Março.2019.

[15] GHAFOORI, N; DUTTA, S. Laboratory Investigation of Compacted No-fines Concreto for Paving Materials. Journal of Material in Civil Engineering, V. 7, No. 3, p. 183-191, 1995.

[16] HOLTOZ, F. da C. Uso de Concreto Permeável na Drenagem Urbana: Análise da Viabilidade Técnica e do Impacto Ambiental. 2011, 139p. Dissertação (Mestrado em Engenharia Civil), Porto Alegre, BRRS, Rio Grande do Sul, 2011.

[17] INSTITUTO BRASILEIRO DE GEOGRAFIA E ESTÁTISTICA (IBGE). Contagem da População 2019. Disponível em < http://www.ibge.gov.br/home/estatistica/populacao/contagem2019/default.shtm>Acessado em 30/03/2019.

[18] KUCK, T. N. ALVES, D. S. Análise da impermeabilização da área urbana de Manaus (19872006) com o uso do modelo de mistura espectral mesma. In: Anais XV Simpósio Brasileiro de Sensoriamento Remoto - SBSR, Curitiba, PR, Brasil, 30 de abril a 05 de maio de 2011, INPE p.0996. Disponível em: http://www.dsr.inpe.br/sbsr2011/files/p0449.pdf. Acessado em 06.09.2014, às 15:44.

[19] LI, J. Mix Design of Pervious Recycled Concrete. GeoHunan International Conference - Material Design, Construction, Maintenance, and Testinf of Pavements. V. 195, n. 15, p. 103- 108, Ago. 2009.

[20] MARTIN, J.F.M. Aditivos para Concreto. In: Concreto: Ensino, pesquisa e realizações. São Paulo: IBRACON, 2005. p. 381-406.

[21] MILOGRANA, J. (2009). Sistemática de Auxílio à Decisão para a Seleção de Alternativas de Controle de Inundações Urbana. Tese de Doutorado em Tecnologia Ambiental e Recursos Hídricos, Publicação PTARH. TD - 05/09, Departamento de engenharia Civil e Ambiental, Universidade de Brasília, Brasília, DF, 316p.

[22] MUlligan, A. N., 2005. Attainable Compressive Strength of Pervious Concrete Paving Systens. University Orlando, Florida. 145p.

[23] NEVILLE, ADAM. Propriedades do concreto. II Edição, São Paulo, Pini, 1997.

[24] PERVIOUS CONCRETE PAVIMENT. Disponível em: <http//www.perviouspavement.org> Acessado em 24 Abril 2019, às 14:01.

[25] POLASTRE, Bruno, SANTOS, Lara Damha. Concreto Permeável, AUT 221 - Arquitetura, Ambiente e Desenvolvimento Sustentável. Universidade de São Paulo, 206.

[26] PINTO, L. L. C. A. O Desenvolvimento de Pavimentos Permeáveis como Medida Mitigadora da Impermeabilização do Solo Urbano. São Paulo, 2011, 255 p.

[27] SHI.X. Journal of Cleaner Production. Permeable Concret Pavements: A review of environmental benefits and durability. V, P.01-18, 2018.

[28] TENNIS, P.D.; LEMING, M.L.; AKERS, D.J. Pervious Concrete Paviments, EB302, Portland Cement Association, Skokie, IIIinois, 36p.,2004.

[29] TUCCI, CARLOS E.M. Brasília: Ministério das Cidades, 2005. 194p. (Saneamento para Todos; 4ovolume).

[30] VIRGILIIS, A L. Procedimentos de Projeto e Execução de Pavimentos Permeáveis Visando Retenção e Amortecimento de Picos de Cheias. 2009. 49 p., 96 p. Dissertação (Mestrado em Engenharia), Departamento de Engenharia de Transportes, Universidade de São Paulo. São Paulo 2009.

[31] YUKIO C; MARTINS A; ISSA F. Drenagem subsuperficial de pavimentos - Conceitos e dimensionamentos. São Paulo: Oficina de Textos, 2013. P. 182, 114. 


\title{
Capítulo 8
}

Estudo das propriedades mecânicas da argamassa com resíduo de vidro temperado para revestimento

\author{
Adenize Souza de Carvalho \\ Elias Belarmino da Cruz Lins \\ Luciane Farias Ribas \\ Sara Santarém
}

Resumo: A Construção Civil apresenta dois aspectos negativos de observação imediata: um deles é a excessiva produção dos materiais, e o outro se dá pela geração de resíduos sólidos durante os processos de construção. Infelizmente, há uma má destinação desses resíduos sólidos, que não são reaproveitados, reutilizados para gerarem novos produtos, almejando-se assim minimizar os impactos negativos das estruturações civis no meio ambiente. Ademais, faz-se urgente a destinação, o descarte adequado dos refugos sólidos oriundos pela Construção Civil, pois na natureza este material demora cerca de cinco mil anos para se de compor. Consequentemente, a destinação adequada destes restos ajudaria a diminuir o volume dos aterros sanitários. A presente pesquisa busca avaliar o estudo das propriedades físicas e mecânicas de argamassa com substituição parcial do agregado miúdo por resíduo de vidro temperado para revestimento. Para análise em apreço foram confeccionadas argamassas com $20 \%$ de substituição do agregado natural miúdo com traço de 1:6 para revestimento, comparando com traço de referência. Optouse pela produção de corpos de provas cilíndricos, que pudessem caracterizar sua consistência e determinação da compressão, corpos de provas em formatos de prismas para registrar valores de resistência à compressão axial, e resistência à tração na flexão, além da realização de ensaios de determinação da granulometrias do agregado miúdo e resíduo de vidro. Para análise estatística dos resultados utilizou-se o método da ANOVA e como complementação a análise de componente principal. Observou-se que o percentual de $20 \%$ de substituição ocasionou uma resistência significativa na compressão e flexão. Os juntados demonstraram ótimos resultados quanto à compressão na idade de 14 (quatorze) dias. Neste ensaio observou-se não existir empecilho para que o vidro não pudesse ser utilizado como substituição de $20 \%$ do agregado natural por resíduo de vidro temperado. Não obstante, na idade de 14 dias constatou-se que as duas dosagens de argamassa obtiveram resistências equivalentes, considerando não ter ocorrido vibração antes dos ensaios de compressão, ainda assim não impacta na sua aplicação, como também atende às especificações de resistência mínima para revestimento.

Palavras-chave: Vidro. Argamassa. Revestimento. 


\section{INTRODUÇÃO}

A indústria da construção civil é uma das maiores consumidoras de matérias primas naturais, sendo responsável pelo consumo de aproximadamente $50 \%$ dos recursos naturais extraídos da natureza (MALTA, 2012), por isso para minimizar os efeitos a reciclagem é a solução.

Os impactos ambientais da indústria, principalmente com relação aos recursos naturais, tem-se expandido cada vez mais, aumentando a influência de emissões de gases em escalas regionais, de acordo com ABRELPE (2017) o Brasil produz em média 980 mil toneladas de embalagens de vidro por ano, usando cerca de $45 \%$ de matéria-prima reciclada na forma de cacos. Parte deles foi gerada como refugo nas fábricas e parte retornou por meio da coleta seletiva.

Apesar de o vidro ser um material 100\% reciclável, não são biodegradáveis e se acumula por vários anos em aterros e lixões. Uma solução para esse problema é um estudo da incorporação deste resíduo em argamassas, uma vez que este material é composto basicamente por sílica ou dióxido de silício $\left(\mathrm{SiO}_{2}\right)$. (Meyer e Xi, 1999) descrevem que o vidro e o cimento são quimicamente incompatíveis e que os álcalis do cimento e a sílica do vidro reagem na presença de umidade, resultando em uma reação química denominada reação álcali-sílica.

Nos últimos anos vários estudos foram efetuados através de pesquisas realizadas por (SHI e ZHENG, 2007; TOPÇU e CAMBAZ, 2004; SHAO et al.,1998). POLLEY et al. (1999) no âmbito da substituição parcial de materiais convencionais por resíduos de diversas indústrias. Devido isso, as indústrias têm alertado para o desenvolvimento de alternativas tecnológicas, pelo fato do alto consumo de matérias primas, a fim de poupar recursos para as gerações futuras e preservar o meio ambiente.

Desse modo, o presente trabalho busca desenvolver uma alternativa para a redução do consumo de agregados naturais, utilizando o resíduo de vidro temperado. Este estudo propõe a sua aplicação como agregado em argamassas de revestimento, para isso as propriedades mecânicas e durabilidade da argamassa serão avaliadas. O método das dosagens aplicadas obedecerá a NBR 13281 (ABNT, 2018) buscando proporcionar ótimos desempenhos, para isto, as propriedades foram analisadas e comparadas entre si, por meio de análise de variância (ANOVA).

\section{METODOLOGIA}

\subsection{PLANEJAMENTOS EXPERIMENTAIS}

Foi elaborado um planejamento experimental, de modo a cumprir os objetivos estabelecidos neste estudo, buscando avaliar as propriedades mecânicas consideráveis para o bom desempenho da argamassa de acordo com a NBR 13281 (ABNT, 2018). o fluxograma do procedimento experimental realizado neste trabalho está representado na figura 1.

Figura 1 - Fluxograma do planejamento experimental.

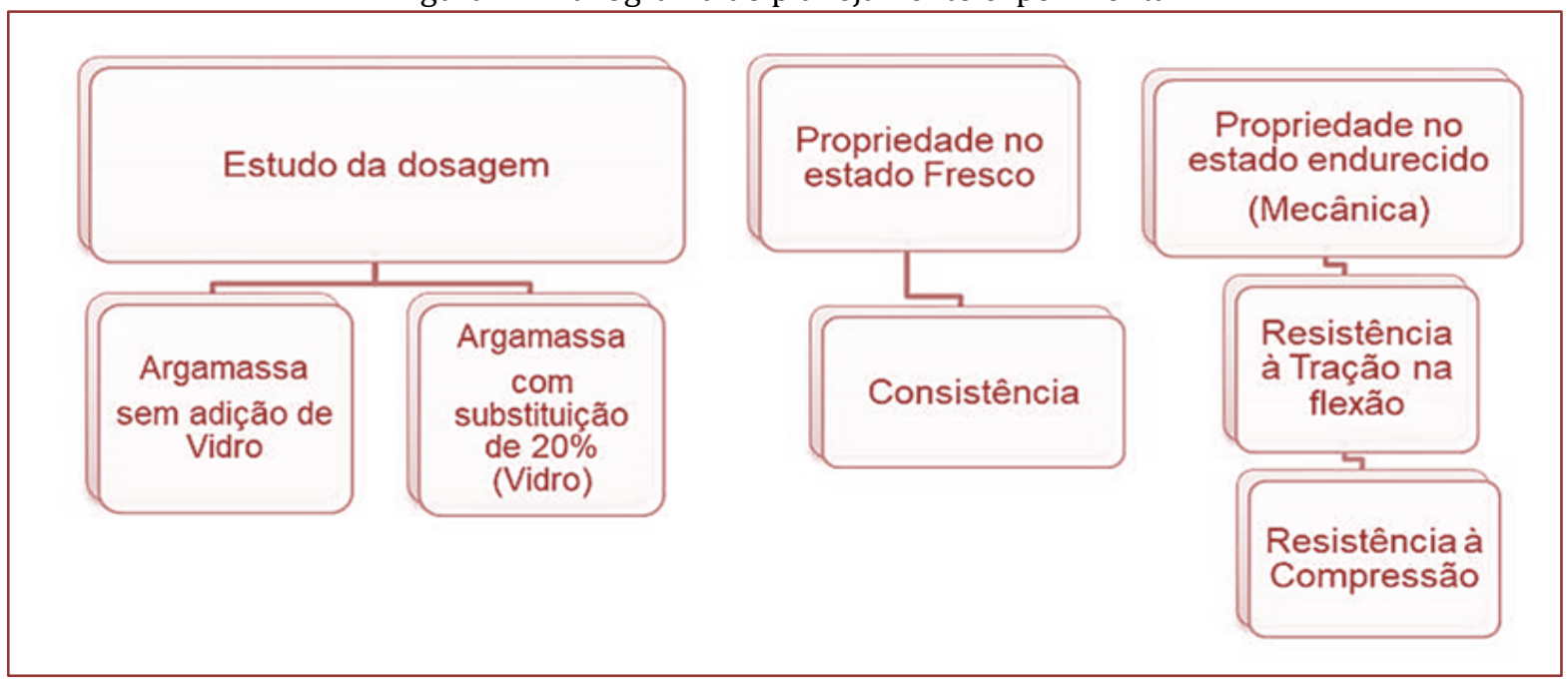

Fonte: Elaborado pelos alunos, 2019. 


\subsubsection{MATERIAIS}

\subsubsection{CIMENTO PORTLAND CP II F-32}

O cimento escolhido para a confecção das argamassas foi o CP II F-32 da marca Cauê, devido sua maior durabilidade, melhor trabalhabilidade e adensamento, suas propriedades atendem desde estruturas em concreto armado até argamassas de assentamento e revestimento. As características químicas e físicas do cimento são apresentadas nas tabelas 1 e 2 .

Tabela 1 - Composição química do cimento CPII - F - 32

\begin{tabular}{|l|c|}
\hline \multicolumn{1}{|c|}{ Composto químico } & Percentual(\%) \\
\hline Anidrido carbônico (CO2) & $\leq 5,0$ \\
\hline Óxido de magnésio (MgO) & $\leq 6,5$ \\
\hline Trióxido de enxofre (SO3) & $\leq 4,0$ \\
\hline Perda ao fogo & $\leq 6,5$ \\
\hline Resíduo insolúvel & $\leq 2,5$ \\
\hline Equivalente Alcalino & - \\
\hline
\end{tabular}

Fonte: Adaptada pelos autores por dados fornecidos pelo fabricante, 2019.

Tabela 2 - Análises físicas do cimento CPII - F - 32

\begin{tabular}{|c|c|}
\hline Característica & Índices \\
\hline Blaine $\left(\mathrm{cm}^{2} / \mathrm{g}\right)$ & $>2600$ \\
\hline Expansibilidade a frio & $\leq 5$ \\
\hline Tempo de início de pega (h:min) & $\leq 10$ \\
\hline Resistência à compressão & MPA \\
\hline 3 dias & $\geq 10$ \\
\hline 7 dias & $\geq 20$ \\
\hline 28 dias & $\geq 32$ \\
\hline
\end{tabular}

Fonte: Adaptada pelos autores por dados fornecidos pelo fabricante, 2019.

\subsection{3 ÁGUA}

A água proveniente do sistema de abastecimento da universidade federal do amazonas foi estabelecida de acordo com a NBR 15900-1 (ABNT, 2009), onde especifica os requisitos para que a água seja considerada adequada. A quantidade de água adicionada à mistura cimentícia foi definida de acordo com o traço 1:6.

\subsubsection{AREIA}

Classificada de acordo com a NBR 7211 (ABNT, 2015). A areia utilizada como agregado miúdo foi quartzosa fina, foram analisados e peneirados de acordo com a normativa vigente, onde a figura 2 mostra as peneiras utilizadas no ensaio.

Figura 2 - Peneiramento do Agregado miúdo.

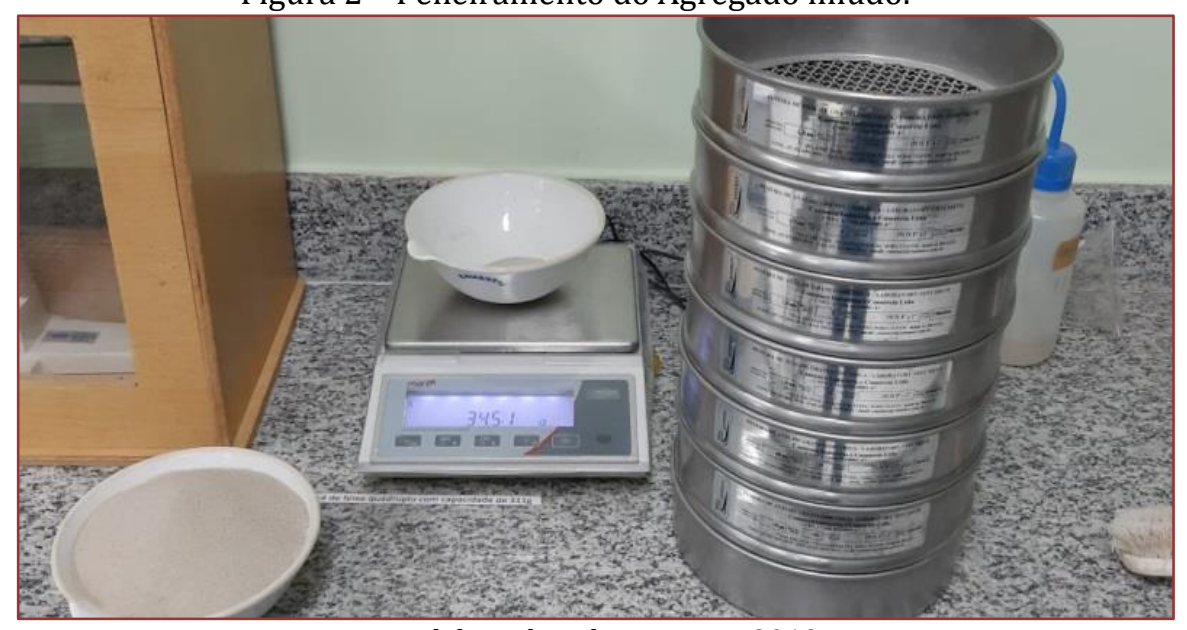

Fonte: Elaborada pelos autores, 2019. 
Os ensaios granulométricos realizados através da técnica do peneiramento seco, de acordo com a NBR NM 248 (ABNT, 2011). Foram utilizados aproximadamente $1 \mathrm{~kg}$ de agregado miúdo, por meio deste ensaio foi determinado à dimensão máxima característica e módulo de finura dos agregados, a tabela 3 mostra as massas retida e passante acumulado para determinação das dosagens.

Tabela 3 - Distribuição granulométrica da areia

\begin{tabular}{|c|c|c|c|}
\hline \multicolumn{2}{|c|}{ Peneira (Mm) } & $\begin{array}{c}\text { Massa } \\
\text { Retida } \\
\text { (g) }\end{array}$ & $\begin{array}{c}\text { Passante } \\
\text { Acumulado } \\
(\%)\end{array}$ \\
\hline 6,30 & 2,82 & & 2,82 \\
\hline 4,75 & 1,86 & & 4,68 \\
\hline 2,38 & 12,21 & & 16,89 \\
\hline 1,18 & 58,2 & & 75,09 \\
\hline 0,60 & 129,35 & & 204,44 \\
\hline 0,15 & 766,23 & & 970,67 \\
\hline \multicolumn{2}{|c|}{ Fundo } & & 9,33 \\
\hline
\end{tabular}

Fonte: Elaborado pelos autores, 2019.

\subsubsection{VIDR0}

As amostras de vidro foram obtidas na empresa Vidros Rio Ltda. localizada no Pólo Industrial da cidade de Manaus. Optou-se pela coleta em "pó sedimentado", visando minimizar os eventuais riscos de acidentes e por possuir composição de partículas próximas da areia. Os ensaios granulométricos realizados através da técnica do peneiramento seco, de acordo com a NBR NM 248 (ABNT, 2011) estando descrita na tabela 4.

Tabela 4 - Distribuição granulométrica do vidro

\begin{tabular}{|c|c|c|}
\hline \multirow{2}{*}{$\begin{array}{c}\text { Peneira (Mm) } \\
\text { Massa Retida (g) }\end{array}$} & $\begin{array}{c}\text { Passante Acumulado } \\
(\%)\end{array}$ \\
\hline 6,30 & 1,02 & 1,02 \\
\hline 4,75 & 2,29 & 3,31 \\
\hline 2,38 & 86,45 & 89,76 \\
\hline 1,18 & 544,37 & 634,13 \\
\hline 0,60 & 121,97 & 756,1 \\
\hline 0,15 & 160,91 & 917,01 \\
\hline Fundo & 82,99 & 1000 \\
\hline \multicolumn{2}{|c|}{ Fonte: Elaborada pelos autores, 2019.} \\
\hline
\end{tabular}

A massa específica foi determinada pelo ensaio realizado por PAIVA (2009), para o segmento do ensaio foi utilizado o mesmo tipo de vidro com sua massa específica $2.323,66 \mathrm{~kg} / \mathrm{m}^{3}$.

\subsubsection{SUPERPLASTIFICANTE}

Visando a obtenção de uma mesma consistência e relação água/cimento, se faz necessário o uso de superplastificante de terceira geração Glenium 51 da BASF, com propriedades descritas na tabela 5.

Tabela 5 - Uso do Superplastificante de 3o geração Glenium 51 da BASF.

\begin{tabular}{|c|c|c|c|c|c|c|}
\multicolumn{2}{c}{ Função } & \multicolumn{2}{c}{ Base Química } & \multicolumn{2}{c}{ Aspecto } & \multicolumn{2}{c}{ Cor } & \multicolumn{2}{c}{$\begin{array}{c}\text { Massa } \\
\text { Específica }\end{array}$} & Sólidos & $\begin{array}{c}\text { Tempo Médio } \\
\text { de Reação }\end{array}$ \\
\hline $\begin{array}{c}\text { Superplastificante de } \\
\text { 3o Geração }\end{array}$ & Policarboxilatos & Líquido Viscoso & Bege & $1,072 \mathrm{~g} / \mathrm{cm}^{3}$ & 31,2 & $8 \mathrm{~min}$ \\
\hline
\end{tabular}

Fonte: Adaptado de dados fornecidos por PAIVA (2009). 


\subsection{MÉTODOS}

\subsubsection{ESTUDO DE DOSAGEM E PREPARAÇÃO DA ARGAMASSA}

Estudos realizados com aplicação de vidros em argamassas demonstraram a utilização de traços experimentais adotados neste estudo. SHI et al. (2005), PAIVA et al. (2009) e SANTOS (2016) , por exemplo encontraram resultados satisfatório no desempenho de argamassas com até $20 \%$ de substituição do agregado miúdo.

As argamassas foram produzidas com o traço 1:6 com substituição de $20 \%$ do agregado miúdo por resíduo de vidro temperado, além da argamassa de referência com $0 \%$ de substituição. Para definição do ensaio, aplicaram-se as indicações baseados na NBR 13281 (ABNT, 2018), onde a mesma especifica todos os requisitos exigíveis para argamassa de assentamento e revestimento de paredes e tetos. Os traços e as dosagens da argamassa estão descritos na tabela 6, o consumo em metros cúbicos.

Tabela 6 - Quantidade de materiais em $\mathrm{m}^{3}$.

\begin{tabular}{|c|c|c|c|c|c|}
\hline \multirow{2}{*}{ Mistura } & \multicolumn{4}{c}{ Consumo Kg/m $/ \mathrm{m}^{3}$ de argamassa } & \multicolumn{2}{c|}{$\begin{array}{c}\text { SP (em relação a } \\
\text { massa do }\end{array}$} \\
\hline REFERÊNCIA & 181,34 & 1088,03 & 1454,81 & 145,07 & $0,1 \%$ \\
\hline VIDRO & 294,32 & 1418,10 & 312,37 & 235,46 & $0,1 \%$ \\
\hline
\end{tabular}

Fonte: Autoria própria, 2019.

As argamassas foram confeccionadas em misturador mecânico, segundo as orientações da NBR 7215 (ABNT, 2019). Possuindo motor com duas velocidades, alimentação: $220 \mathrm{~V}-60 \mathrm{HZ}$. A figura 3 mostra o equipamento utilizado. Inicialmente foram acrescentado a água e o cimento, movimentando o misturador na velocidade lenta por 20 segundos, para a formação da pasta. Ainda com o misturador ligado foram acrescentados os agregados miúdos e depois homogeneizados, também com velocidades de 20 segundos. Misturou-se todo material na velocidade lenta até completar um minuto.

Após um minuto aumentou-se a velocidade e manteve-se até 4 minutos, em seguida limparam-se as laterais com uma espátula com lâmina de 200 milímetros de comprimento e 25 milímetros de largura, com bordas retas e cabo de madeira, deixou-se em repouso por 2 minutos, feito isto retornou a ligar em velocidade rápida até atingir 2 minutos, assim finalizando a etapa de preparo no total de 8 minutos.

Figura 3 - Misturador Mecânico utilizado na homogeneização da mistura.

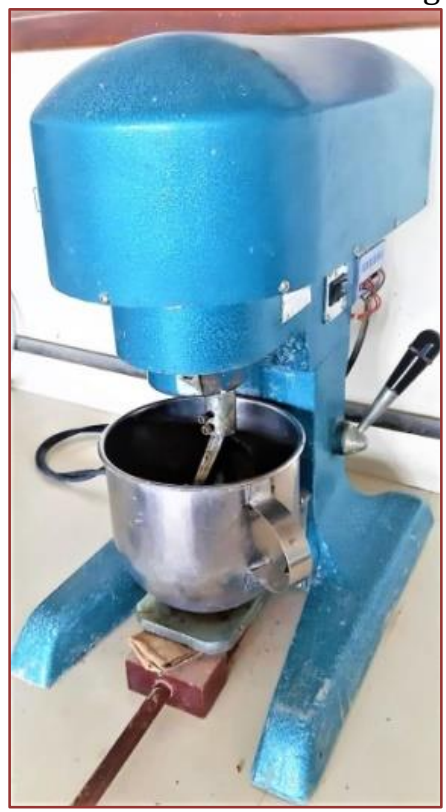

Fonte: Autoria Própria, 2019. 


\subsubsection{DETERMINAÇÃO DE ÍNDICE DE CONSISTÊNCIA}

Para determinação do índice de consistência (figura 4), utilizaram os aparelhos, de acordo com a NBR 7215 (ABNT, 2019), o índice de consistência é o medidor principal para definir a trabalhabilidade e resistência da argamassa, pelo ensaio de mesa de consistência (flow table) detalhado e normatizado pela NBR 13276 (ABNT, 2016).

Figura 4 - Golpes Com o Soquete e rasamento do molde.

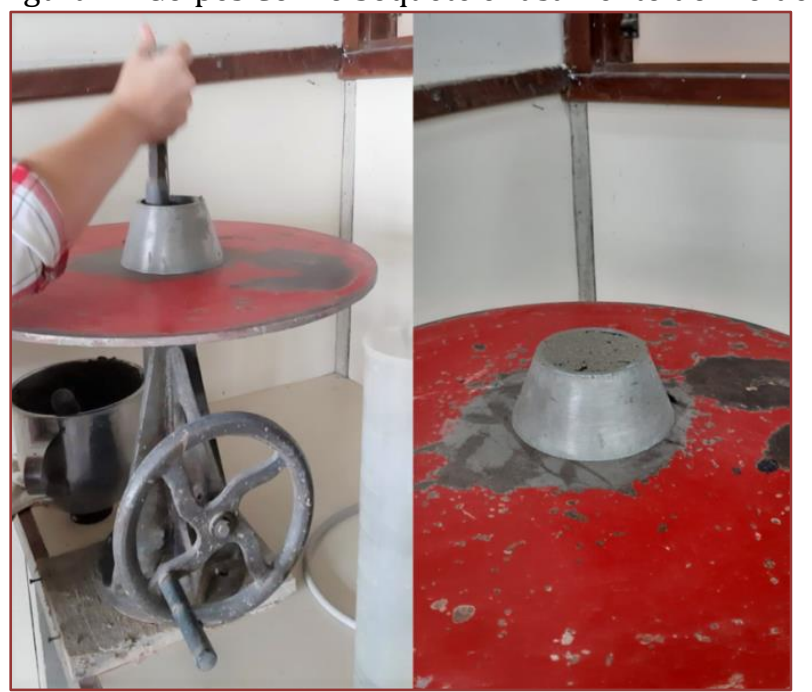

Fonte: Elaborada pelos autores, 2019.

\subsubsection{PROPRIEDADES NO ESTADO ENDURECIDO (MECÂNICA)}

Para este ensaio foram confeccionadas primas apresentados na figura 5, para determinação da resistência mecânica da argamassa, conforme a NBR 13279 (ABNT, 2018).

Figura 5 - Corpos de provas para ensaio no estado endurecido.

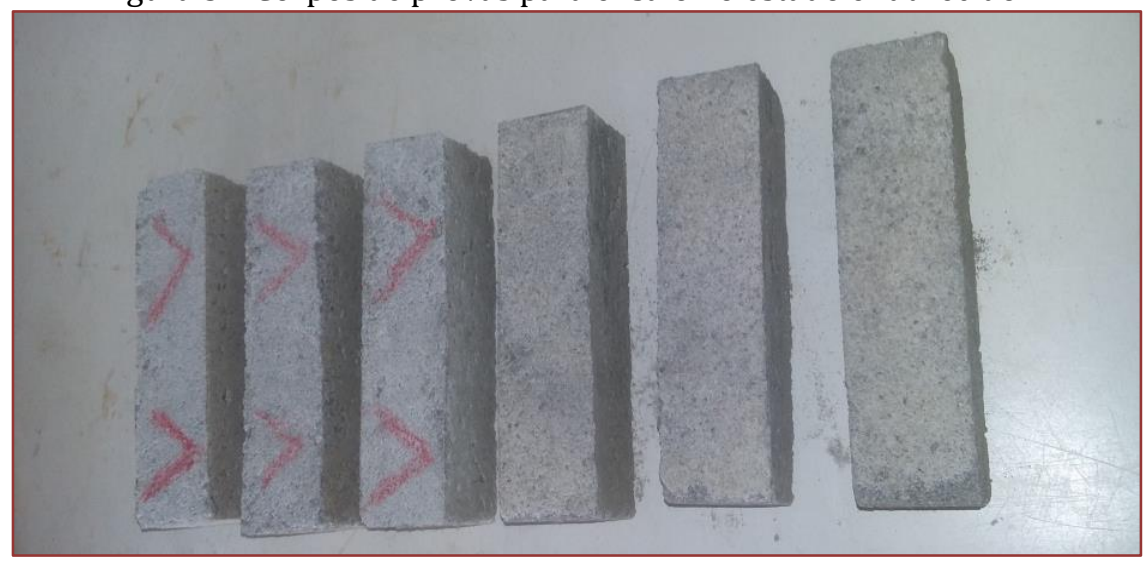

Fonte: Elaborada pelos autores, 2019

\subsubsection{RESISTÊNCIA À TRAÇÃO NA FLEXÃO}

Inicialmente Moldaram-se três corpos-de-prova prismáticos, conforme figura 6, com argamassa recémpreparada, a NBR 13279 (ABNT, 2018) descreve todo processo de ensaio para esta etapa. 
Figura 6 - Aplicação da argamassa no corpo de prova prismático.

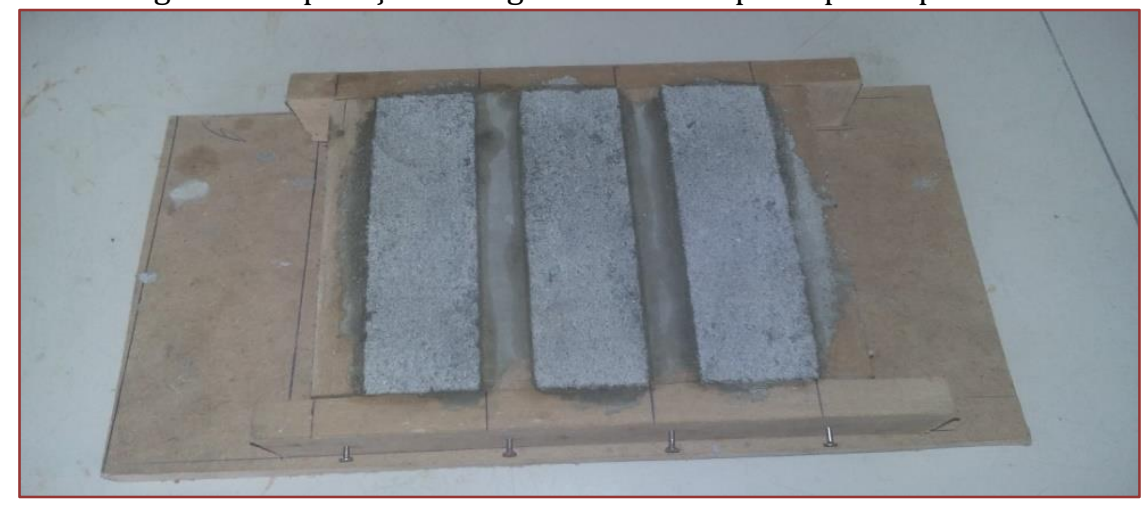

Fonte: Elaborada pelos autores, 2019.

De acordo com a mesma norma vigente, realizaram-se os ensaios de ruptura do corpo-de-prova, apresentadas na figura 7, a resistência à tração na flexão é calculada segundo a equação.

$$
R f=\frac{1,5 F f L}{40^{3}} \quad(02)
$$

Figura 7 - Ensaios de Resistência à Tração na Flexão.

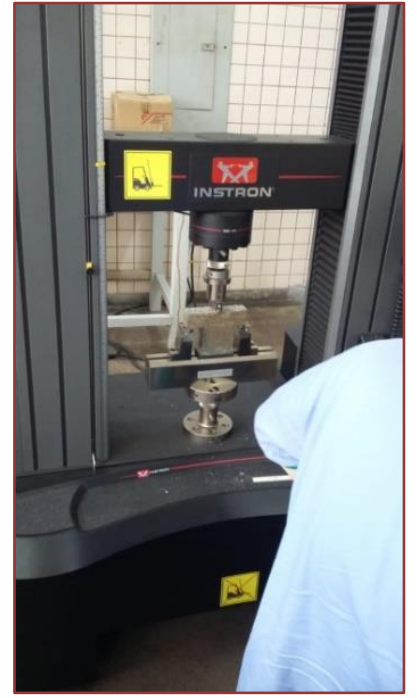

Fonte: Elaborada pelos autores, 2019.

\subsubsection{RESISTÊNCIA À COMPRESSÃO AXIAL}

O Teste de resistência à compressão geralmente dá uma visão geral da qualidade da argamassa ou concreto, porque a força está diretamente relacionada à estrutura da pasta de cimento hidratada. Conforme a NBR 13279 (ABNT, 2018) foram adotados os mesmos processos para ensaio até a ruptura do corpo-de-prova, apresentada na figura 8, feito isto a resistência à compressão é calculada segundo a equação.

$$
R \mathrm{c}=\frac{F \mathrm{c}}{1600}
$$


Figura 8 - Ensaio de Resistência à compressão axial.

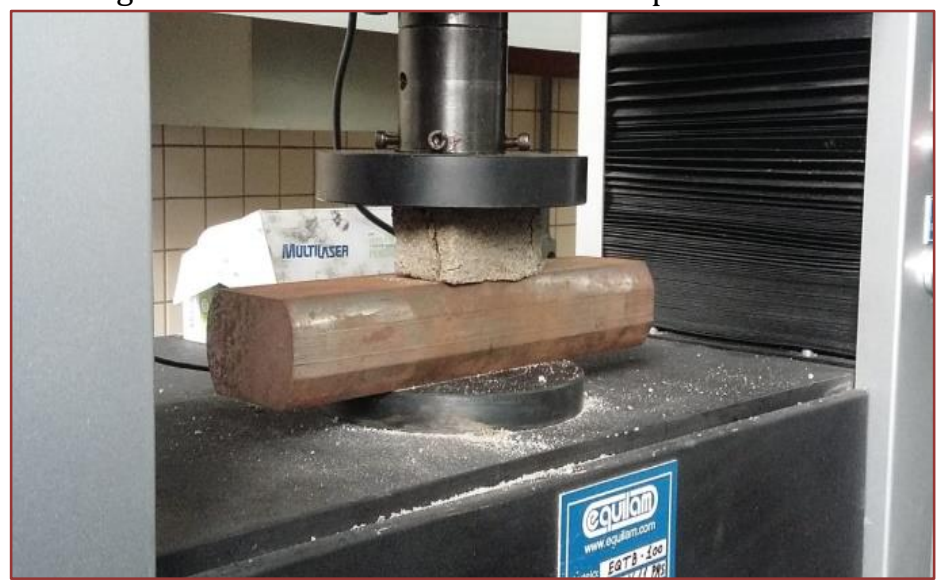

Fonte: Elaborada pelos autores, 2019

\section{RESULTADOS E DISCUSSÕES}

Neste capítulo serão apresentados e discutidos os resultados obtidos no programa experimental. Serão apresentados por meio da média aritmética de cada amostra, seguida de desvio padrão correspondente. Para análise de dados utilizou-se o método da ANOVA por meio do software ORANGE®.

\subsection{DISTRIBUIÇÕES GRANULOMÉTRICAS}

Através das distribuições granulométricas (Gráficos 1 e 2), foi possível comparar e identificar que o resíduo de vidro apresentaram partículas maiores que a do agregado miúdo, utilizado nesta pesquisa. Como resultado das distribuições ao longo dos ensaios, observou-se uma uniformidade das partículas, reduzindo os índices de vazios presentes nos corpos de provas. Desta forma podem atuar como efeito fíler, preenchendo os espaços deixados pelas partículas, proporcionando maior densidade para a matriz, enfatizando a NBR 7211 (ABNT, 2019), que diz respeito à espessura da areia, considerada fina.

Entretanto observa-se que pelo fato do vidro possuir grãos maiores, interferiu no aumento da resistência, visto que ao fato do agregado miúdo ser menor fez com que ele preenchesse os índices de vazios predominantes na argamassa, considerando que não é o objetivo do trabalho classificar a reação existente nas partículas adequadas para determinado tipo de ensaio.

Gráfico 1 - Tamanho das Partículas da Areia

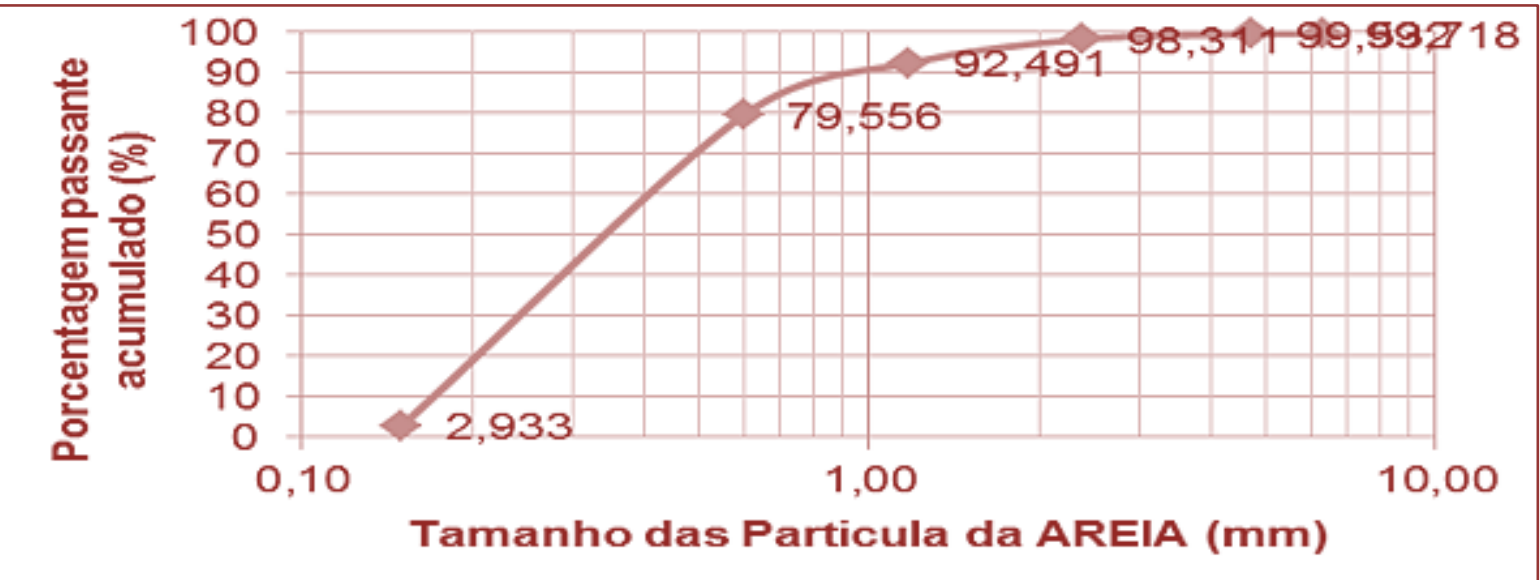

Fonte: Elaborado pelos autores, 2019.

Com relação ao tempo de cura dos corpos de prova, houve uma absorção maior de água nos prismas de referência, pelo fato da areia absorver mais água que o resíduo de vidro. A dosagem executada apresentou um ótimo desempenho em relação a outros trabalhos pelos autores (MEYER E XI,1999; SHI e ZHENG, 
2007; TOPÇU CAMBAZ, 2007 ; POLEY, 2001) que também realizaram como substituição tanto do agregado miúdo como do cimento.

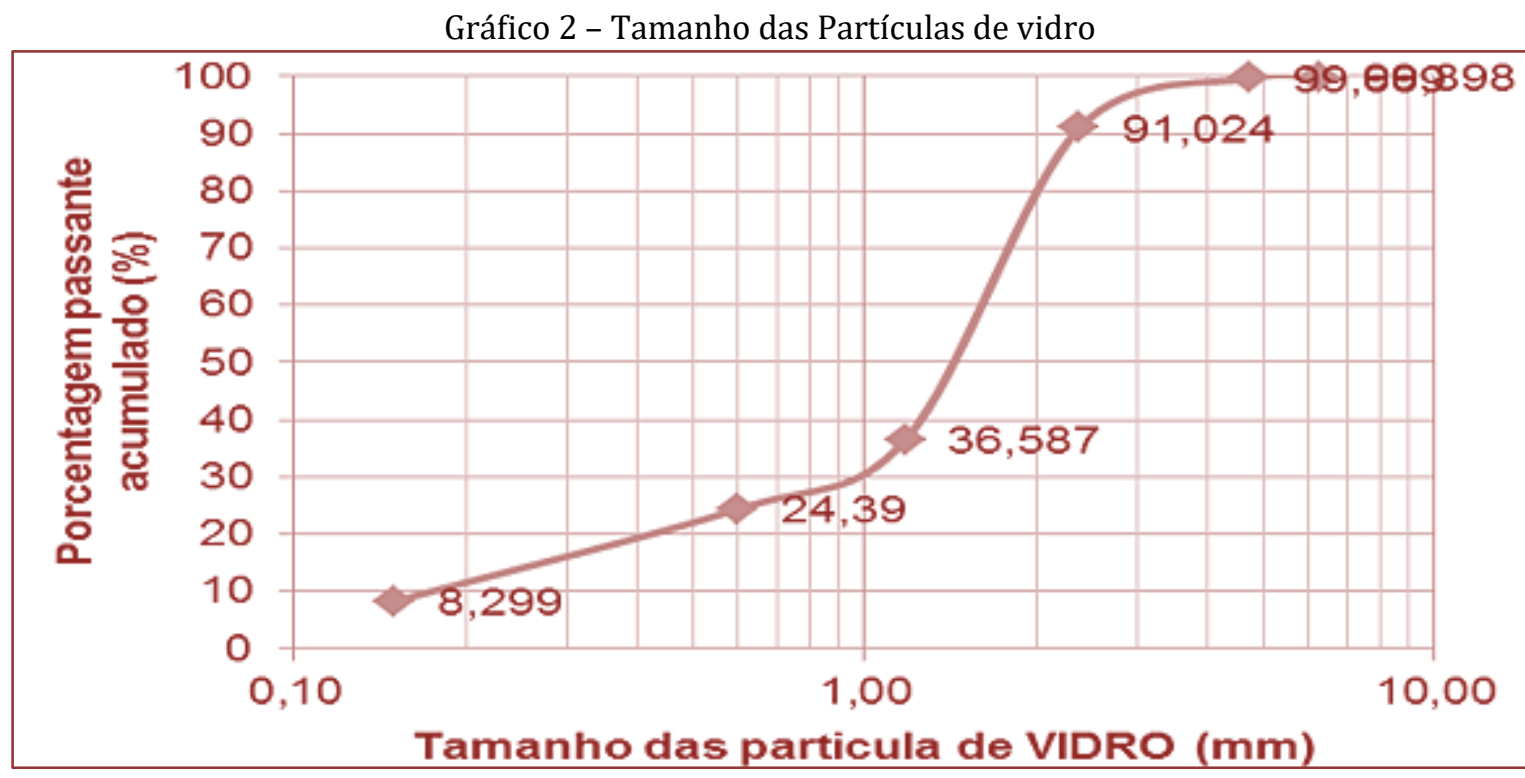

Fonte: Elaborado pelos autores, 2019.

\subsection{1 ÍNDICE DE CONSISTÊNCIA}

Foi possível efetuar o ensaio de consistência, verificando um ótimo resultado da trabalhabilidade e desempenho dos corpos de prova. A Figura 9 apresenta o espalhamento da argamassa, na qual não foram observadas segregação e exsudação, estando dentro do padrão que especifica um valor adequado de acordo com a NBR 13276 (ABNT, 2016).

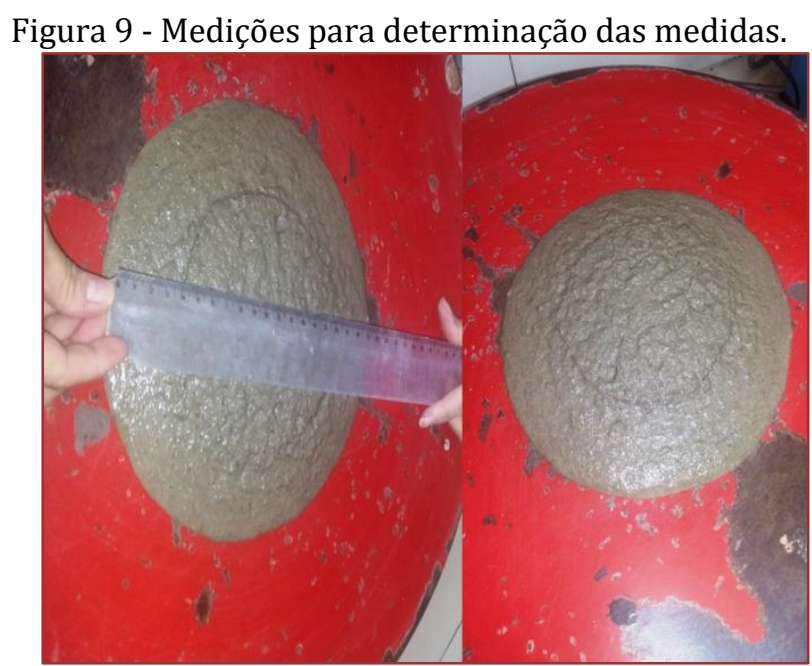

Fonte: Elaborada pelos autores, 2019.

A tabela 7 indica o índice de consistência, conforme descrita, a consistência foi mantida constante e variou-se pouco quando comparado ao traço de referência, ressaltando que o vidro não absorve a mesma quantidade de água que a areia. 
Tabela 7 - Resultados de índice de consistência.

\begin{tabular}{|c|c|c|}
\hline \multicolumn{1}{|c|}{ Traço } & a/c & Consistência $(\mathrm{cm})$ \\
\hline 1:6 Referência & 0,8 & 22,5 \\
\hline 1:6 20\% vidro & 0,8 & 21,5 \\
\hline
\end{tabular}

Fonte: Autoria própria, 2019.

0 teor de aditivo superplastificante nas misturas também influencia diretamente nos valores obtidos dos ensaios no estado fluido. No entanto foi necessário um teor de superplastificante de 1,5 gramas, para obter um espalhamento adequado, visto que esse aditivo tem a função de melhorar a trabalhabilidade da argamassa.

\subsubsection{RESISTÊNCIA À TRAÇÃO NA FLEXÃO}

A média dos ensaios de resistência à tração aos 14 dias e o fator de eficiência de corpos de prova da argamassa de referência e com teores de substituição parcial do agregado miúdo por resíduo de vidro temperado, estão apresentados na tabela 8.

Tabela 8 - Resultado de resistência à tração na flexão

\begin{tabular}{|c|c|}
\hline Traço & Resistência à tração na flexão $(\mathrm{MPa})$ \\
\hline 1:6 Referência & 1,71 \\
\hline 1:6 Referência & 1,55 \\
\hline 1:6 Referência & 0,33 \\
\hline $1: 620 \%$ vidro & 1,82 \\
\hline $1: 620 \%$ vidro & 1,78 \\
\hline $1: 620 \%$ vidro & 1,91 \\
\hline
\end{tabular}

Fonte: Elaborada pelos autores, 2019.

As argamassas com substituição do agregado miúdo, por resíduo de vidro temperado, em geral, obtiveram resultados de resistência superior à argamassa de referência. Entretanto, foram realizadas análises estatísticas, ainda assim não apresentou diferenças estatísticas. Dentre os tratamentos investigados, as argamassas com substituição de 20\% apresentaram maior eficiência, este estudo inferiu em comparações a outros autores que realizaram parâmetros de pesquisas próximas.

Os resultados obtidos nos ensaios de resistência à tração na flexão foram submetidos à análise de variância (ANOVA) para nível de significância, onde identificam evidências de valor, a figura 10 apresenta o desvio padrão dos resultados encontrados com traços de 1:6 das argamassas de referência e com 20\% de substituição do agregado miúdo por resíduo de vidro temperado.

Figura 10 - Resistência à Tração na Flexão.

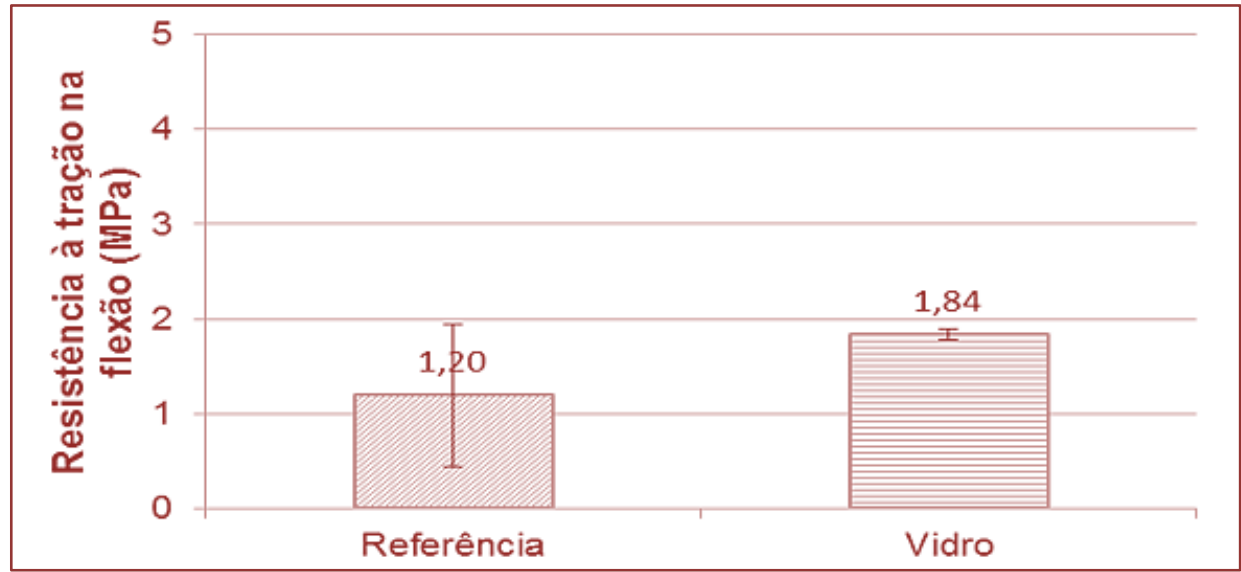

Fonte: Elaborada pelos autores,, 2019. 
De acordo com a ANOVA os resultados não apresentaram diferença significativa ao nível de confiança de 95\% (ver ANOVA no Apêndice A). Visto que se observa um ganho constante da resistência. Espera-se que em idades avançadas para estudos posteriores, as argamassas contendo substituição de resíduo de vidro atinjam resistências à tração superiores as deste estudo.

\subsubsection{RESISTÊNCIA MECÂNICA À COMPRESSÃO AXIAL}

De acordo com (ROSSA JÚNIOR, 2009; Paiva, 2009; SANTOS, 2016) a resistência à compressão e deformação devido aos esforços são fatores que interferem no desempenho de uma alvenaria, desta forma a tabela 9 mostra os resultados obtidos nos ensaios de resistência à compressão, baseados com métodos utilizados na NBR 13279 (ABNT, 2018) aos 14 dias de idade, visto que com essa idade quando se trata de revestimento já pode ser aplicado qualquer outro tipo de acabamento para finalização da estrutura, seguida do desvio padrão referente a cada tipo de argamassa, assim descrita na figura 11.

Tabela 9 - Resultado de resistência mecânica à compressão.

\begin{tabular}{|c|c|}
\hline Traço & Resistência à Compressão $(\mathrm{MPa})$ \\
\hline 1:6 Referência & 12,13 \\
\hline $1: 6$ Referência & 10,86 \\
\hline $1: 6$ Referência & 11,37 \\
\hline $1: 620 \%$ vidro & 13,10 \\
\hline $1: 620 \%$ vidro & 9,62 \\
\hline $1: 620 \%$ vidro & 12,31 \\
\hline
\end{tabular}

Fonte: Elaborada pelos autores, 2019.

Na idade de 14 dias, observou-se que as duas dosagens de argamassa obtiveram resistências equivalentes, considerando que não houve vibração antes dos ensaios de compressão, ainda assim não impacta na sua aplicação, como também atende às especificações de resistência mínima para revestimento.

Os resultados obtidos nos ensaios de resistência à compressão foram submetidos à análise de variância (ANOVA), segundo PAIVA (2009) a argamassa de revestimento com agregados reciclados pode a resistência mecânica se manter ou se mostrar superior que a referência, esse acréscimo pode ser atribuído à superfície irregular e porosa das partículas do resíduo, que aumenta a aderência com a pasta de cimento.

Figura 11 - Resistência à compressão axial.

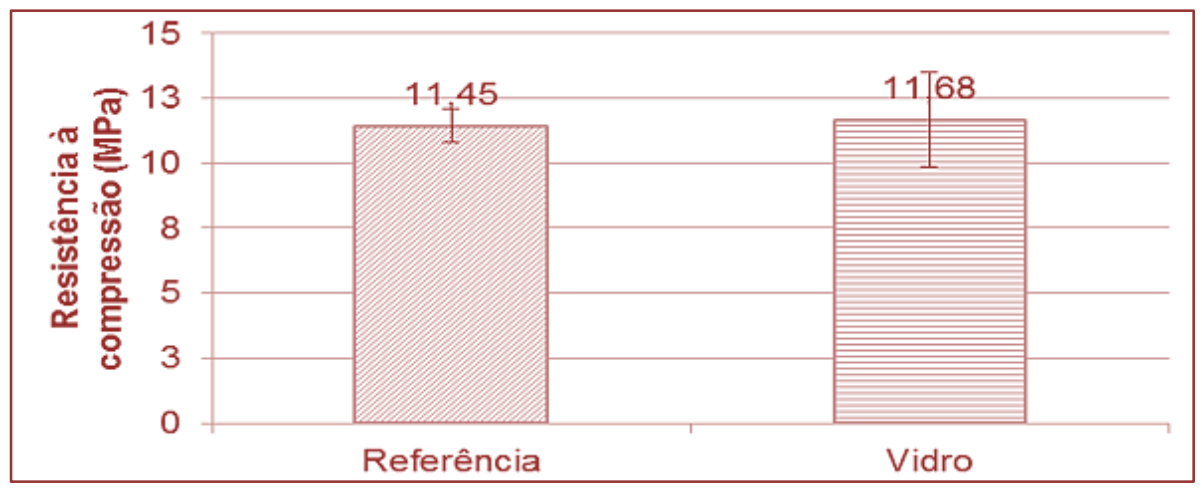

Fonte: Autoria própria, 2019.

Verifica-se também que os resultados de resistência mecânica à compressão, de um modo geral, apresentam uma tendência de aumentar seu valor conforme a utilização do resíduo com o tempo de cura das amostras. Inicialmente, pode-se correlacionar esse comportamento com a variação na quantidade de água as misturas, já que a argamassa de referência foi a que necessitou de maior quantidade de água, bem como a espessura das partículas dos agregados utilizados na dosagem das misturas.

Estudos indicam ainda que, com o mantimento da relação água/cimento, o aumento de resistência de misturas com resíduos ainda são mais notórios, podendo ultrapassar mais de $50 \%$ de resistência da referência, levando em consideração que os resíduos absorvem certa quantidade de água livre, 
melhorando a ligação do cimento com os agregados (SHI \& ZHENG 2007). De acordo com a ANOVA os resultados não apresentam diferenças significativas ao nível de confiança de 95\% (ver ANOVA no apêndice $A$ ).

\section{CONCLUSÃO}

A partir dos resultados de distribuição granulométrica obtida, considerando viável, pode-se concluir que apesar do vidro possuir partículas maiores que a areia, fez com eles se agrupassem melhorando a trabalhabilidade na consistência e indicou um aumento de resistência à tração e à compressão. Neste ensaio foi possível observar que não houve empecilho para que o vidro não pudesse ser utilizado como substituição de $20 \%$ do agregado natural por resíduo de vidro temperado. Na idade de 14 dias, observouse que as duas dosagens de argamassa obtiveram resistências equivalentes, considerando que não houve vibração antes dos ensaios de compressão, ainda assim não impacta na sua aplicação, como também atende às especificações de resistência mínima para revestimento.

Sobre os ensaios de resistências à tração e compressão dos corpos de prova estabelecidos pela NBR 13279 (ABNT, 2018) e classificado pela análise de variância da ANOVA com determinação do desvio padrão, destacou-se satisfatório e dentro dos padrões exigíveis pela análise de variância.

Desta forma pode-se concluir que o resíduo de vidro temperado proveniente da empresa Vidro Rios LTDA., localizada no Polo Industrial da cidade de Manaus, pode ser utilizado em substituições parciais de agregados naturais com percentual de $20 \%$ do volume da areia. Conclui-se que a utilização de resíduo de vidro é uma alternativa tecnicamente viável, uma vez que os resultados de traços de referência e de substituição resultaram valores próximos.

É importante ressaltar que a viabilidade econômica para essa utilização em argamassas e concretos demandam outros estudos mais abrangentes, uma vez que o resíduo de vidro como um material processado para a indústria da construção civil geraria um custo elevado. Porém é fato que há ganhos ambientais quanto à utilização do resíduo de vidro temperado em matrizes cimentícias.

\section{REFERÊNCIAS}

[1] ASSOCIAÇÃO TÉCNICA BRASILEIRA DAS INDÚSTRIAS AUTOMÁTICAS DE VIDRO - ABIVIDRO. Anuário Abividro 2008. Disponível em: <www.abividro.org.br. >. Acesso em: Março, 2019.

[2] ASSOCIAÇÃO BRASILEIRA DE EMPRESAS DE LIMPEZA PÚBLICA E RESÍdUOS ESPECIAIS - ABRELPE . Panorama dos Resíduos Sólidos no Brasil. 2017.

[3]__ASSOCIAÇÃO BRASILEIRA DE NORMAS TÉCNICAS. ABNT NBR 7211 Areia normal para ensaio de cimento Especificações. 4 páginas. Rio de Janeiro, 2019.

[4] _ _ASSOCIAÇÃO BRASILEIRA DE NORMAS TÉCNICAS. ABNT NBR 7215: Cimento Portland - determinação da resistência à compressão - método de ensaio, 8 páginas. Rio de Janeiro, 2019.

[5]__ASSOCIAÇÃO BRASILEIRA DE NORMAS TÉCNICAS. ABNT NBR 13276: Argamassa para assentamento e revestimento de paredes e tetos - Preparo da mistura e determinação do índice de consistência. 3 páginas. Rio de Janeiro, 2016.

[6]__ASSOCIAÇÃO BRASILEIRA DE NORMAS TÉCNICAS. ABNT NBR 13279: Argamassa para assentamento e revestimento de paredes e tetos - Determinação da resistência à tração na flexão e à compressão, 13 páginas. Rio de Janeiro, 2018.

[7] _ ASSOCIAÇÃO BRASILEIRA DE NORMAS TÉCNICAS - ABNT NBR 13281- Argamassa para assentamento e revestimento de paredes e tetos - Requisitos, 7 páginas. Rio de Janeiro, 2018.

[8] _ _ASSOCIAÇÃO BRASILEIRA DE NORMAS TÉCNICAS. ABNT NBR NM 248: Agregados - Determinação da composição granulométrica. 6 páginas. Rio de Janeiro 2011.

[9] MALTA, J. O. Dosagem de concretos produzidos com agregado miúdo reciclado de resíduos de construção e demolição. Dissertação. UFBA - Universidade Federal da Bahia, 2012.

[10] MEHTA, K.; MONTEIRO, P. J. M. Concrete: Microstructure, Properties and Materials. McGraw-Hill, New York, 2006.

[11] Meyer, Y. Xi, J. Mater. in Civil Eng. Evaluation of physical and mechanical properties of concretes produced with ground waste glass as fine aggregate. ASCE 11, 2 (1999). 
[12] PAIVA, O. A. Resíduo Industrial de vidro moído em argamassa de cimento Portland. 2009. 208 f. Dissertação (Mestrado em Engenharia Civil) - Universidade Federal do Amazonas, Manaus, 2009.

[13] ROSSA JUNIOR, J. Adição de escória de alto forno em argamassa colante tipo AC-I. Dissertação. UFPR Universidade Federal do Paraná, 2009.

[14] SANTOS, Diogo. Influência de resíduo de vidro nas propriedades de uma argamassa colante. Dissertação (Mestrado em Engenharia Civil) -- Universidade Estadual do Norte Fluminense Darcy Ribeiro. Centro de Ciência e Tecnologia. Laboratório de Engenharia Civil. Campos dos Goytacazes, 2016. 135p.

[15] SHAO Y, THIBAUT L, SHYLESH M \& DAMIAN R. Studies on concrete containing ground waste glass. Cement and Concrete Research, 2000. p. 91-100.

[16] SHI, C.; ZHENG, K. A. Review on the use of waste glasses in the production of cement and concret. Resources, Conservation and Recycling, v. 52, 2007. p. 234247.

[17] TOPÇU, I.; CANBAZ, M. Properties of concrete containing waste glass. Cement and Concrete Research, v. 34, 2004.pg. 267-274.

[18] POLLEY, C.; CRAMER, S. M.; CRUZ, R. V. Potential for using waste glass in portland cement concrete. Journal of Materials in Civil Engineering, v. 10, n. 4, p. 210-219, nov.2001.

[19] SHAO,Y. LEFORT, T. MORAS, S. RODRIGUEZ, D. Studies on concrete containing ground waste glass. Cement and Concrete Research, v. 30, n. 1, p. 91-100, jan.2000.

[20] SHI,C.; ZENG, K. A review on the use of waste glasses in the production of cement and concrete. Cement and concrete Research, v.52, n . 2, p. $234-247$, dec. 2007. 


\section{ANEXOS}

ANEXO A

Anova Argamassa de Revestimento

Resistência à tração na flexão prismas

\begin{tabular}{|c|c|c|}
\hline \multicolumn{1}{|c|}{$\operatorname{Ff}(\mathrm{N})$} & Média Resistência à Tração na flexão $(\mathrm{MPa})$ \\
\hline 1:6 Referência & 913,90 & 1,71 \\
\hline 1:6 Referência & 824,36 & 1,55 \\
\hline 1:6 Referência & 176,55 & 0,33 \\
\hline $1: 6$ Vidro & 971,66 & 1,82 \\
\hline $1: 6$ Vidro & 950,87 & 1,78 \\
\hline $1: 6$ Vidro & 1016,43 & 1,91 \\
\hline
\end{tabular}

\begin{tabular}{|c|c|c|c|c|c|c|}
\hline \multicolumn{7}{|c|}{ Tabela Anova Flexão } \\
\hline Fonte da variação & SQ & Gl & MQ & F & Valor-P & F crítico \\
\hline Entre grupos & 0,614572 & 1 & 0,614572 & 2,144764 & 0,216912 & 7,708647 \\
\hline Dentro dos grupos & 1,146182 & 4 & 0,286545 & & & \\
\hline Total & 1,760754 & 5 & & & & \\
\hline
\end{tabular}

Tabela de Resistência à Compressão Prismas

\begin{tabular}{|c|c|c|}
\hline & $\mathrm{Fc}(\mathrm{KN})$ & $\begin{array}{c}\text { Média Resistência à Compressão } \\
(\mathrm{MPa})\end{array}$ \\
\hline 1:6 Referência & 19,41 & 12,13 \\
\hline 1:6 Referência & 17,39 & 10,86 \\
\hline 1:6 Referência & 18,21 & 11,37 \\
\hline 1:6 Vidro & 20,96 & 13,10 \\
\hline 1:6 Vidro & 15,405 & 9,62 \\
\hline 1:6 Vidro & 19,725 & 12,31 \\
\hline
\end{tabular}

\begin{tabular}{|c|c|c|c|c|c|c|}
\hline \multicolumn{7}{c}{ Tabela Anova Compressão } \\
$\begin{array}{c}\text { Fonte da } \\
\text { variação }\end{array}$ & SQ & Gl & MQ & F & Valor-P & F crítico \\
\hline $\begin{array}{c}\text { Entre grupos } \\
\text { Dentro dos } \\
\text { grupos }\end{array}$ & 3789992,47 & 1 & 3789992,47 & 5375039,045 & 0,020768 & 7,70864742 \\
\hline Total & 2,82043903 & 4 & 0,70510976 & & & \\
\hline
\end{tabular}




\section{Capítulo 9}

\section{Georeferenciamento: proposta de mapeamento de resíduos de construção e demolição na cidade de Manaus-AM}

Duílio Wendell Rodrigues dos Reis

Fabiana Rocha Pinto

Luciane Farias Ribas

Sara Santarém

Elizandro Aparecido Rocha dos Santos

Resumo: A Lei Federal 10.267 de 28 de agosto de 2001, que versa sobre o Imóvel rural, seus limites, características e confrontações, por meio de memorial descritivo, assinado por profissional habilitado, com a devida ART, contendo as coordenadas dos vértices, se apresenta com a necessidade de utilização do georreferenciamento, que passa a ser uma constante dada as diferentes alterações nas portarias relacionadas as obras. 0 georreferenciamento é uma técnica aprimorada de descrição dos imóveis, contribuindo para o controle, tanto de cadastro destes, como dos direitos reais a eles relativos. Ademias, o objetivo do georreferenciamento de imóveis é a localização específica de um bem individualizado no globo terrestre. Georreferenciar uma casa significa obter as coordenadas geográficas precisas dela, consistindo em delinear seus limites, formando um polígono. A proposta da Gestão Diferenciada dos Resíduos de Construção e Demolição pressupõe, na medida em que é da competência das municipalidades, a definição da destinação dos resíduos sólidos urbanos, uma ação indutora do poder público, de forma que, mesmo que a alteração da destinação seja iniciada com investimentos públicos, permita-se a evolução do processo com investimentos privados que cuidem de canalizar os produtos para o consumo nas próprias atividades construtivas geradoras dos resíduos, sendo o Sistema de Informações Geográficas (SIG), uma ferramenta primordial para subsidiar essa proposta. No entanto, poderá ser feito a utilização de Drones, Aeronave Remotamente Pilotada, para mensuração e cubagem de resíduos. Este Sistema permite, de maneira concisa e técnica, a comparação de materiais que podem ser reutilizados ou descartados de maneira correta. Desta forma, poderá ser expandido seu uso na construção civil na cidade com eficácia.

Palavras-chave: SIG, resíduos, pontos de referenciamentos, mapas, construção civil. 


\section{INTRODUÇÃO}

A construção civil é uma indústria produtiva que tem um papel considerável na economia do país e do mundo, desenvolvendo e criando múltiplos empregos e renda, sendo fundamental para economia brasileira, em especial o Estado do Amazonas. Observa-se que essa área apresenta inúmeros gargalos, dado principalmente por obras irregulares, ocasionando problemas de insalubridade, danos aos patrimônios adjacentes e ao meio ambiente. Uma das ferramentas para prevenir estes danos é o georreferenciamento.

Dentre vários métodos de georreferenciamento, o SIG (Sistema de Informações Geográficas) ou GIS é um dos mais eficazes. No entanto, pode se utilizar Drones, ARP (Aeronave Remotamente Pilotada) para mensuração e cubagem de resíduos. Este Sistema permite, de maneira efetiva e técnica, a comparação de materiais que podem ser reutilizados ou descartados de maneira correta, evitando gastos desnecessários.

Portanto este trabalho pretende contribuir avaliando o uso do sistema de informações geográficas (GIS) no gerenciamento de resíduos de construção e demolição (RCD), por coleta de dados em bases científicas, buscando os motivos de aplicação dessa tecnologia e limitações no gerenciamento de resíduos.

\section{REFERENCIAL TEÓRICO}

\subsection{GEORREFERENCIAMENTO}

Georreferenciamento é um processo que permite determinar a exata posição geográfica de um imóvel e sua área por meio de um mapeamento que referencia os vértices de seu perímetro ao sistema geodésico brasileiro. Assim, passa a ser possível saber exatamente, a localização de uma propriedade dentro de qualquer território.

Esta técnica consiste em tornar as coordenadas conhecidas num dado sistema de referência adotado pelo país e tem sido muito difundida nos dias atuais, devido à necessidade de se obter delimitação real de uma determinada área sem correr os riscos de sobreposição. Nesse contexto, o GPS Geodésico e Estações Totais são, na atualidade, os instrumentos mais eficientes para a coleta de informações espacializadas pontuais, lineares e poligonais. 0 georreferenciamento é uma técnica aprimorada de descrição dos imóveis, que contribui para o controle tanto de cadastro destes como dos direitos reais a eles relativos, consistindo em delinear seus limites formando um polígono.

Georreferenciamento é uma técnica adotada pelo INCRA (Instituto Nacional de Colonização e Reforma Agrária) como uma forma de padronizar a identificação de imóvel rural. Ocorre por meio de um processo de reconhecimento das coordenadas geográficas do local, a partir da utilização de mapas ou imagens. 0 processo pode ser feito por meio do levantamento topográfico para definir as características referentes à dimensão e localização da propriedade. Pelo processo de georreferenciamento cada imóvel tem definido quais são os seus limites, características e confrontação. Essas definições são feitas por meio da descrição das coordenadas dos vértices limitantes referenciadas no Sistema Geodésico Brasileiro.

A principal finalidade do georreferenciamento é o levantamento das características do imóvel. No entanto, para que essa determinação seja feita de forma padronizada, adotou-se uma metodologia oficial, exigida para todos os proprietários de imóveis rurais, por meio do CAR (Cadastro Ambiental Rural). O INCRA determina que qualquer imóvel rural, seja ele público ou privado, deve ser georreferenciado, sendo obrigatório para as propriedades de mais de 100 ha $^{-1}$. Primeiramente, é preciso a atuação de um profissional ou empresa que execute serviços de elaboração do material necessário para apresentar ao Instituto Nacional de Colonização e Reforma Agrária (INCRA) a fim de receber certificação.

Para receber a certificação do INCRA, a documentação deve obedecer aos regulamentos constantes da Lei $10.267 / 01$. 0 documento é extremamente importante, pois qualquer alteração de área ou de titularidade para ser efetivada deve ter o certificado, que corresponde à planta georreferenciada da propriedade. A terceira etapa é declarar o imóvel junto ao Cartório de Registro de Imóveis.

Georreferenciar uma imagem ou mapa é tornar suas coordenadas conhecidas num dado sistema de referência. Este processo inicia-se com a obtenção das coordenadas (pertencentes ao sistema no qual se planeja georreferenciar) de pontos da imagem ou do mapa a serem georreferenciados, conhecidos como Pontos de Controle, locais que oferecem uma feição física perfeitamente identificável, tais como intersecções de estradas e de rios, represas, pistas de aeroportos, edifícios proeminentes, topos de montanha, dentre outros. A obtenção das coordenadas dos Pontos de Controle pode ser realizada em campo a partir de levantamentos topográficos, GPS - Global Positioning System (EPUSP, 2006) 
O decreto 4.449 de 2002 que oficializou a lei 5.868 de 1972 acarretou na exigência do georreferenciamento de imóveis rurais, definindo, ainda, que todo imóvel rural deve ser georreferenciado em até dez anos, dependendo do tamanho da propriedade.

O georreferenciamento estabelece a posição de feições a partir de premissas técnicas impostas por órgãos, leis, empresas etc., enquanto que, o geoprocessamento consiste em associar esses dados espaciais a informações recolhidas e em seguida disponibilizar de análises de território. Nota-se a diferença desses segmentos da Geociências, com diferentes finalidades, porém promovendo inúmeras informações complementares e relevantes para diferentes áreas.

O geoprocessamento, uma das tecnologias diretamente ligadas ao SIG, é uma potente ferramenta que auxilia em diversas atividades, principalmente em trabalhos de Cartografia, visto que utiliza técnicas matemáticas e computacionais, tais como os Sistemas de Informação Geográfica (GIS), o Sensoriamento Remoto (SR) e o Sistema de Posicionamento Global (GPS), para o tratamento de informações e dados geográficos que podem resultar na produção de mapas, cartogramas, gráficos e sistematizações em geral.

Os dois processos, georreferenciamento e geoprocessamento, podem se misturar caso seja necessário utilizar o resultado de um geoprocessamento para configurar ou informar algum fato sobre uma área a ser georreferenciada.

O conhecimento da realidade física permite a gestão eficiente do território. A definição correta dos limites, dos confrontantes e da forma de utilização de uma parcela de solo fornece, às autoridades responsáveis pelo cadastro e pelo registro de terras, as informações necessárias para o conhecimento preciso do território. Porém, esses benefícios não se restringem somente às instituições ligadas diretamente à gestão territorial, mas se estendem à sociedade como um todo. Dados corretos geram segurança para o setor financeiro e bancário, para as seguradoras e, em última instância, para as pessoas que compram, vendem, dividem ou unificam imóveis.

Antes da norma de georreferenciamento de imóveis rurais, a delimitação de terras era feita com base em informações geralmente imprecisas sobre estradas, rios, árvores etc. Mesmo assim, há necessidade de revisões, ajustando à nova realidade brasileira. A sociedade como um todo é a maior beneficiária de um sistema de gestão territorial que integre de forma eficaz o cadastro e o registro de imóveis. Esse sistema protege os proprietários, torna clara a definição dos limites dos imóveis, garante segurança quanto a procedimentos jurídicos, regulariza a matrícula e as certidões das propriedades, cria condições de acesso a instrumentos de política pública, facilita transações financeiras e, mais importante, gera valorização de bens.

Por meio do conhecimento da malha fundiária do País, o Estado controla a ocupação irregular de terras, melhora a tributação, combate ao desmatamento, evita a sobreposição de propriedades, direciona políticas públicas, desenvolve ações de regularização fundiária, identifica terras devolutas, elimina focos de grilagem de terras e integra os cartórios de registro público às instituições responsáveis pelo controle de terras. Um imóvel irregular é apenas uma parcela de terra, com valor bastante depreciado. Por outro lado, um imóvel devidamente matriculado possibilita o acesso ao crédito, já que pode ser oferecido em garantia pelo pagamento de dívidas. Com acesso a financiamentos, o proprietário adquire insumos e a produção do imóvel aumenta, gerando crescimento econômico no País.

Na atualidade do Brasil e do mundo, estão sendo utilizados para execução de georreferenciamento, vários tipos de equipamentos de ponta, especificamente GPS geodésico, que tem precisão exigida pelo órgão competente para regularização de determinada área de acordo com a Lei Federal 10.267/2001 vinculava o georreferenciamento a ato normativo a ser expedido pelo INCRA.

Atualmente utiliza-se equipamentos como o VANT (Veículo Aéreo Não Tripulado), também chamado de ARP (Aeronave Remotamente Pilotada), equipamento que tem todas as propriedades de um GPS geodésico, porém sua utilização tem mais precisão e trabalhabilidade, é mais avançada, sobrevoando determinada área e fotografa calculando vértices, volumes e áreas. A ARP utiliza posições via satélite, possibilitando a análise de imagens aéreas. Popularmente conhecido como drone, esse equipamento é operado por controle remoto ou de forma autônoma, por meio de softwares embarcados em computadores ou tablet's. 0 controlador traça previamente um trajeto e soltar o drone, que segue à risca a pré-determinação.

O GPS GEODÉSICO tem como especificações técnicas, Placa Notável OEM 729 de 555 canais, avançada detecção e suavização de interfaces, taxa de atualização de $100 \mathrm{~Hz}$, tempo de inicialização RTK (Real Time Kinematic) típica de $10 \mathrm{seg}$ (linha de base $\leq 20 \mathrm{~km}$ ), Confiabilidade RTK de 99,9\%, possui comando e leds integrados para informação, além de avisos sonoros, memória interna de 8 GB e capaz de expandir para 
até 32 GB de memória. Sensor de inclinação com correção automática de inclinação de até $30^{\circ}$.

0 equipamento mede $156 \mathrm{~mm}$ de diâmetro x $76 \mathrm{~mm}$ de altura, é resistente a poeira e água IP67 (IEC60529), resistente a quedas de até $2 \mathrm{~m}$, sobre o bastão. Possui uma bateria interna e removível, de 2,2 V e $6.800 \mathrm{mAh}$, com autonomia superior a $13 \mathrm{~h}$, utilizando suas baterias simultâneas. Possui rádio interno e capaz de utilizar rádio externo, bluetooth 2.1 + EDR Classe 2, Wifi IEEE 802.11 b/g/n e módulo 4G LTE. Acompanha acessórios que são receptores base que capta sinais via satélite por um de terminado tempo, dependendo do tipo de levantamento executado em campo. Juntamente com receptor rover que tem a função de rastrear determinada área pelo operador conectado ao Receptor Base.

A Estação Total tem como especificações técnicas, precisão, velocidade de observação e o posicionamento da Estação Robótica Focus 35, controlando de forma horizontal e vertical os motores, eliminando a necessidade de bloqueio de movimentos tradicionais. 0 Focus 35 inclui um sensor de rastreamento, utilizando a tecnologia de rastreamento LockNGo FastTrack. Assim o instrumento pode ser bloqueado constantemente no prisma. É composto pelo software de campo Survey Pro, com interface Windows CE fácil de navegar, intuitiva e sensível ao toque.

É possível que um único profissional realize os levantamentos topográficos com alta precisão através das comunicações robóticas estabelecidas, controlando as funções da Focus 35 a partir da mira conforme o movimento no local de trabalho. 0 instrumento remoto pode então ser dirigido para o operador robótico usando a posição GPS e uma pesquisa subsequente é realizada rapidamente para recuperar o alvo no receptor robótico. Tecnologia esta que faz com que haja redução significativa de desperdício de tempo, aprimorando sua eficiência no trabalho de campo. É um equipamento fácil de usar, econômico e resistente, ideal para levantamento e dados topográficos.

\subsection{GERENCIAMENTO DOS RESÍDUOS DA CONSTRUÇÃO CIVIL}

A indústria da construção é um dos maiores contribuintes para os resíduos (Sapuay, 2016). Os resíduos de construção e demolição (CDW) foram responsáveis por 30 e 40\%, respectivamente, do total de resíduos sólidos em todo o mundo (Jin et al., 2019), sendo 20\% no Japão (Lu et al., 2017), 36\% na União Europeia (Xu et al., 2019) e até 67\% nos Estados Unidos (Lopez Ruiz et al., 2020) .

Com a rápida urbanização e renovação urbana nos últimos anos, estimou-se que aproximadamente 2,4 bilhões de CDW eram gerados anualmente na China (Wang et al., 2019a). Em Shenzhen, como exemplo, 459 planos de unidades de renovação urbana foram anunciados de 2009 a 2016 (UPLRCSM, 2016). Do mesmo modo, a geração anual de CDW em Shenzhen alcançaria 7,7 milhões de $\mathrm{m}^{3}$ em média de 2016 a 2020 (excluindo o solo escavado) (Li et al., 2019). 0 gerenciamento da CDW está gradualmente evoluindo para um problema social e tem sido examinado extensivamente (Yuan e Shen, 2011). 0 aterro sanitário é a prática atual para a maioria dos CDW inertes na China (Ding et al., 2018). No entanto, o descarte de CDW em aterros sanitários não pode atender a requisitos ecologicamente corretos e é considerado a pior opção (Cherubini et al., 2009).

O aterro sanitário de CDW não apenas ocupa recursos valiosos da terra, mas também apresenta ameaças potenciais ao solo, à água e ao ar circundante (Li et al., 2017a; Wang et al., 2019b). Várias economias desenvolvidas promoveram a reciclagem de CDW em vez de aterro. Por exemplo, a taxa de recuperação de CDW é superior a 90\% no Japão, Coréia do Sul, Alemanha e Holanda (Comissão Europeia, 2015; Yuan e Wang, 2017).

Muitos estudiosos avaliaram os impactos ambientais do processo de manuseio de CDW. Alguns desses, compararam o impacto ambiental de diferentes estratégias de gerenciamento de CDW (Marzouk e Azab, 2014; Ortiz et al., 2010; Simion et al., 2013) enquanto outros examinaram as produções de agregado natural (NA) e agregado reciclado (AR) (Biswas, 2014; Butera et al., 2015; Marinkovic et al., 2010). No entanto, concluíram com base em um caso específico do local (Bovea e Powell, 2016). Além disso, pouco esforço foi dedicado para avaliar o impacto ambiental da reciclagem móvel de CDW (Blengini e Garbarino, 2010).

Em grandes metrópoles com alta densidade populacional, como Shenzhen, a reciclagem móvel está ganhando popularidade porque reduz a exigência de transporte de CDW e ocupação de terras a longo prazo, mas que ainda é necessário a avliação da vantagem da reciclagem móvel no desempenho ambiental. Considerando essa lacuna de pesquisa mencionada, úteis para o governo municipal gerenciar melhor a reciclagem de CDW. 
Um dos maiores contribuintes para os resíduos é a Indústria de construção. 0 gerenciamento da construção e demolição de resíduos, gradualmente está evoluindo para um problema social e extensivamente tem sido examinado. A prática atual para maioria dos CDW é o aterro sanitário. No entanto é considerado a pior opção como descarte e não pode atender a requisitos ecologicamente corretos.

Aterro sanitário de construção e demolição apresenta recursos valioso, porém aponta ameaças potenciais ao solo, ar e água em envolvimento. Tratando-se de economias desenvolvidas, foram promovidas reciclagens de CDW superior a 90 \% no Japão, Coréia do Sul, Alemanha e Holanda.

Com a exigência de transporte de construção de demolição, a reciclagem móvel ganha popularidade. Porém sua vantagem precisa ser avaliada em função da análise de quantitativo de impacto ambiental. Com isso, serão reduzidos a dependência do contexto e terá ampliação do horizonte de análise. Assim, os resultados poderão fornecer informações úteis para governo municipal trazendo melhor gerenciamento na reciclagem de construção e demolição.

O CDW em larga escala leva inevitavelmente ao desperdício de recursos da terra e à poluição das águas subterrâneas e do ar, o que representa uma ameaça significativa ao meio ambiente. Comparada com o aterro, a reciclagem é a melhor maneira de descartar o CDW dado pelo melhor desempenho ambiental. (Ding et al., 2018). No entanto sugeriu-se que há impacto de várias estratégias de gestão de resíduos nos recursos, consumo de energia e emissões atmosféricas (Bovea e Powell, 2016; Ghisellini et al., 2018).

A avaliação do ciclo de vida (ACV) tem sido cada vez mais usada para auxiliar nessas avaliações. Os estudos que focaram na avaliação do gerenciamento de CDW usando ACV ainda eram limitados (Laurent et al., 2014). No entanto, outros estudos descrevem o ciclo de vida dos edifícios, incluindo seu fim de vida (Bovea e Powell, 2016) mencionando que os esforços consideráveis se concentraram na comparação do impacto ambiental de várias estratégias de gerenciamento de CDW.

Kucukvar et al. (2014) desenvolveram um modelo de avaliação do ciclo de vida híbrido, rastreando os impactos de três estratégias de gerenciamento de resíduos: reciclagem, aterro e incineração. Seu estudo constatou que a reciclagem de materiais de construção proporcionou um impacto ambiental mais positivo do que as outras duas abordagens. Penteado e Rosado (2016a) compararam os impactos do aterro e reciclagem de pequenos e grandes geradores de CDW e concluíram que a reciclagem teve menos impacto adverso.

Hossain et al. (2017) conduziram um estudo de caso para avaliar e comparar os impactos ambientais de diferentes sistemas de classificação de CDW, e um considerável benefício ambiental líquido foi observado através de um sistema de classificação no local devido ao maior potencial de reciclagem. Dahlbo et al. (2015) constataram que a reciclagem de resíduos normalmente gerava maiores benefícios ambientais que a recuperação de energia, com poucas exceções.

Simion et al. (2013) empregaram a Pegada Ecológica (EF) como um novo indicador e metodologia para avaliar a sustentabilidade ambiental em diferentes cenários e concluíram que o cenário mais apropriado para o gerenciamento de CDW era sua reciclagem com o menor FE. Além disso, um número menor de estudos comparou os impactos ambientais de NA e AR. Por exemplo, Hossain et al. (2016) descobriram pela LCA que a AR produzida a partir de CDW, seja grossa ou fina, obteria melhores benefícios ambientais em comparação com NA.

Faleschini et al. (2016) concluíram que a AR poderia desempenhar um papel importante para alcançar as metas de sustentabilidade para a indústria da construção. Através do seu uso, os recursos terrestres existentes podem ser preservados, o que está de acordo com os requisitos da Comissão Europeia. Rosado et al. (2017) relataram que a produção de AR era preferível à de materiais naturais para as categorias de impacto de inorgânicos respiratórios, ecotoxicidade terrestre, ocupação do solo, aquecimento global e energia não renovável usando uma avaliação do ciclo de vida atribuicional.

Marinkovic et al. (2010) descobriram que os impactos ambientais do concreto agregado reciclado podem ser iguais ou até menores do que os impactos do concreto agregado natural em uma situação específica com o método de Avaliação de Impacto do Ciclo de Vida.

Resultado de Serres et al. (2016), sugeriram que as amostras recicladas apresentavam bom comportamento ambiental, mesmo que os materiais reciclados (areia e agregados) envolvessem operações diferentes. Lopez et al. (2016) demonstraram o uso efetivo de agregados reciclados da CDW para produzir meios-fios de concreto, com um desempenho bastante bom nas emissões e economia de energia. Esses estudos revelaram o benefício ambiental da reciclagem de CDW sob vários aspectos, usando 
a abordagem da ACV. No entanto, a maioria desses estudos realizou a avaliação de impacto ambiental por meio de apenas um estudo de caso. Essa abordagem tem forte dependência da conclusão no contexto específico do caso investigado.

Rara é a atenção dada ao impacto ambiental do processo de reciclagem móvel. Com a ajuda da instalação de reciclagem móvel, o DW pode ser tratado no local e, portanto, reduzir a distância do frete. 0 desempenho ambiental da reciclagem móvel será realizado usando a ACV com base em vários estudos de caso mencionado anteriormente já o CDM é usado quando o meio ambiente é ameaçado inevitavelmente em larga escala, o CDW leva ao desperdício de recursos da terra e à poluição das águas subterrâneas e do ar.

A reciclagem comparada com aterro é a melhor alternativa para descartar o CDW em função do seu desempenho ambiental. Estudos concluído por estudiosos mostram que algumas estratégias impactam na gestão de resíduos nos recursos, consumo de energia e emissões atmosféricas. A técnica de avaliação do ciclo de vida (AVC), tornou-se cada vez mais usada para auxiliar nessas avaliações. Consideravelmente baseado em estudos, esforços se concentraram na comparação do impacto ambiental de várias estratégias de gerenciamento de construção e demolição.

Foi desenvolvido um modelo de avaliação do ciclo de vida híbrido por Kucukvar et al. (2014), rastreando os impactos de três estratégias de gerenciamento de resíduos: reciclagem, aterro e incineração. Com nesse estudo, foi contatado que a reciclagem de materiais de construção proporcionou um impacto ambiental positivamente acima que as outras abordagens. Foi comparado por Penteado e Rosado (2016), os impactos de aterro e reciclagem de pequenos e grandes geradores de construção e demolição, concluíram que reciclagem teve menos impacto adverso.

Constatado por Dahlbo et al (2015), que a reciclagem de resíduos normalmente causava benefícios ambientais maiores que a recuperação de energia com poucas exceções. Já Simion et al (2013), a Pegada Ecológica como um novo indicador e metodologia para avaliação da sustentabilidade ambiental, chegando a conclusão que o melhor a ser implantado para gerenciamento de construção e demolição, seria a reciclagem.

Relatado por Rosado et al (2017), que a produção do AR era preferível à de materiais naturais usando o ciclo de vida atribuicional para as categorias de impacto de inorgânicos respiratórios, ecotoxicidade terrestre, ocupação do solo, aquecimento global e energia não renovável.

Descoberto por Marinkovic et al (2010), que os impactos ambientais do concreto agregado reciclado podem ser menores ou iguais do que os impactos do concreto agregado natural para utilização do método de avaliação de impacto do ciclo de vida em uma situação específica.

Sugerido por Serres et al. (2016), as amostras recicladas apresentavam bom comportamento ambiental, mesmo que os materiais reciclados areia e agregados envolvessem operações diferentes. Com a Avaliação de Impacto do Ciclo de Vida, foi revelado através de estudos o benefício ambiental da reciclagem de construção e demolição. No entanto, por meio de apenas um estudo de caso, foi realizado a avaliação de impacto ambiental.

0 volume elevado de resíduos de construção, associado à escassez de espaço nos aterros, incentivou pesquisadores e profissionais a pensar em soluções alternativas e sustentáveis, como reutilização e reciclagem. Altas capacidades de reciclagem de resíduos de construção e demolição (C\&DW), permitem taxas de reutilização superiores a 80\%, foram alcançadas na Alemanha, Dinamarca e Holanda (Euro-stat e Union Européenne, 2015; Morata e Sandoval, 2012). Os países em desenvolvimento, no entanto, ainda ficam para trás na reciclagem e reutilização de C\&DW (Duan et al., 2019). Entre as barreiras para classificar e processar a C\&DW está o fato de que os edifícios têm vida útil longa e vários proprietários com atitudes diferentes em relação à reciclagem.

Além do próprio edifício, a ausência de instalações de processamento com capacidades adequadas e tecnologias de reciclagem estabelecidas pode representar uma barreira. 0 mercado de agregados reciclados também está subdesenvolvido em muitos países (Huang et al., 2018). Finalmente, incentivos legais e econômicos e monitoramento adequado são raros e, portanto, obstruem gravemente a gestão eficiente da C\&DW (Silva et al., 2017). De fato, o comportamento de um contratado no gerenciamento de C\&DW é impulsionado pela viabilidade econômica do processo primeiro e pela presença de uma supervisão governamental em segundo (Wu et al., 2017).

O principal objetivo deste estudo é fornecer uma ferramenta de apoio à decisão economicamente viável e ambientalmente amigável para a gestão da C\&DW, especialmente nos países em desenvolvimento. Essa 
ferramenta está estruturada em torno da reabilitação de pedreiras em instalações de processamento, uma abordagem atraente que reduz a objeção pública resultante da síndrome do "não no meu quintal".

Embora as pedreiras forneçam um conjunto inicial de locais potenciais de classificação e reciclagem, são necessárias considerações adicionais para garantir um sistema econômico e eficiente em termos ambientais de instalações de reciclagem.

Estudos anteriores implementaram modelos de Sistemas de Informações Geográficas (GIS) ou modelos matemáticos para resolver o problema de seleção de local de instalação. No entanto, esses modelos não foram responsáveis por toda a cadeia de valor ou resultaram em áreas nas quais foram necessárias análises adicionais específicas do local.

Tais estudos frequentemente se concentravam na limitação dos efeitos ambientais devido às emissões, enquanto negligenciam a influência das características da terra na localização das instalações. Em contraste, o presente trabalho combina métodos de modelagem geoespacial e matemática para obter um conjunto único de locais de processamento com a menor objeção pública e governamental possível.

A parte geoespacial dessa estratégia usa uma análise multicritério automatizada para selecionar de um conjunto de pedreiras as que podem ser reabilitadas em instalações de recuperação de materiais e aterros sanitários. As entradas do modelo e as medidas adotadas podem ser facilmente modificadas para refletir as condições em qualquer localidade. Buscam minimizar os danos ambientais de acordo com as preferências dos acionistas e com os regulamentos existentes. A parte de modelagem matemática deste estudo é um modelo baseado em otimização que delineia o conjunto de pedreiras adequado para uso ao considerar toda a cadeia de suprimentos de agregados reciclados.

O modelo matemático traça a maximização dos lucros ao longo da vida útil das instalações. Como resultado do modelo é uma estimativa do lucro total ou perda total do sistema de gerenciamento de resíduos proposto. Evidentemente, a precisão dos resultados depende da precisão da entrada fornecida ao modelo.

Enormes quantidades de entulhos são geradas através da Indústria de construção, com uma composição diversificada nos vários estágios da construção do escoramento e acabamento. 0 volume de resíduos de construção associado à escassez de espaços nos aterros, trouxe incentivo para profissionais e pesquisadores a darem soluções alternativas e sustentáveis como reutilização e reciclagem.

Com base nas pesquisas de Morata e Sandoval, 2012 (Euro-stat e Union Européenne) capacidades altas de reciclagem de resíduos de construção e demolição que permitem taxas de reutilização superior a $80 \%$, foram alcançadas na Alemanha, Dinamarca e Holanda. No entanto, Duan et al, (2019) afirma que ainda existem países que ficam para trás na reciclagem e reutilização de construção e demolição.

Para classificação e processamento dos resíduos de construção e demolição, está o fato de que os edifícios têm vida útil longa e vários proprietários com atitudes diferentes em relação à reciclagem. Além do edifício, a ausência de instalações de processamento com capacidades adequadas e tecnologias de reciclagem estabelecidas pode representar uma barreira. Huan et al (2018), afirma que o mercado de agregados e reciclados também está subdesenvolvido em muitos países.

Segundo Wu et al (2017), o comportamento de um contratado no gerenciamento de construção e demolição é impulsionado pela viabilidade econômica do primeiro processo e pela presença de uma supervisão governamental. 0 objetivo principal deste estudo é fornecer uma ferramenta de apoio à decisão economicamente viável e ambientalmente amigável para o gerenciamento de construção e demolição principalmente nos países em desenvolvimento.

Essa ferramenta está estruturada em torno da reabilitação de pedreiras em instalações de processamento, uma abordagem que atrai e reduz a objeção pública resultante da síndrome do "não no meu quintal". Apesar de as pedreiras fornecerem um conjunto inicial de locais potenciais de classificação e reciclagem, são necessárias considerações adicionais para utilização de um sistema econômico e eficiente em termos de instalações de reciclagem.

Estudos implementaram Sistemas de Informações Geográficas (GIS) ou modelos matemáticos para dar solução ao problema de seleção de local de instalação. Porém, esses modelos não foram responsáveis por toda a cadeia de valor e resultaram em áreas nas quais foram necessárias análises específicas in loco.

Estudos frequentemente concentravam-se na limitação dos efeitos ambientais devido às emissões enquanto negligenciam a influência das características da terra na localização das instalações. Através de análises espaciais e matemática para obtenção de um conjunto único de locais de processamento com a 
menor objeção pública e governamental.

A análise espacial dessa estratégia utiliza um multicritério automatizado para seleção de um conjunto de pereiras que podem ser reabilitadas em instalações de recuperação de materiais e aterros sanitários. Tais medidas podem ser facilmente modificadas para refletir as condições em qualquer localidade, tendo como objetivo minimizar danos ambientais de acordo com as preferências dos acionistas e com os regulamentos existentes.

O modelo matemático tem como objetivo maximizar os lucros ao longo da vida útil das instalações. 0 resultado é uma estimativa de lucro total ou perda total do sistema de gerenciamento de resíduos proposto. Consequentemente a precisão é fundamental para os resultados da precisão da entrada fornecida ao modelo.

Ao analisar quantitativamente o impacto ambiental da reciclagem móvel de resíduos de demolição (DW), examinando vários projetos de demolição vários casos reduzirão a dependência do contexto específico do projeto e ampliarão o horizonte de análise.

\section{O uso de GIS no gerenciamento dos Resíduos da Construção Civil}

Sendo necessário para o ambiente operacional o software GIS é consideravelmente mais baixo que o do BIM e BD. Por outro lado, o modelo baseado em SIG com dados abrangentes pode ser facilmente aplicado em outras áreas (Paz et al., 2018; Robinson e Kapo, 2004; Seror e Portnov, 2018). Essa tecnologia pode ser facilmente aplicada a outros estudos de casos. Podendo ser facilmente promovido.

Diversos pesquisadores adotaram a tecnologia GIS, uma ferramenta poderosa para armazenamento de dados geográficos, análise e construção de modelos (EPA, 2014). Para possuir vantagens o SIG é usado na coleta, armazenamento, integração, processamento, análise e apresentação de dados e possui uma forma espacial para auxiliar os pesquisadores em seus estudos.

Ooshaksaraie e Mardookhpour (2011) usaram o GIS para exibir a melhor localização das áreas de armazenamento de resíduos e como uma ferramenta de suporte para analisar as relações espaciais no gerenciamento de resíduos de C\&D. Wu et al. (2016) ilustraram que o SIG é uma ferramenta adequada que pode gerenciar a direção do fluxo do fluxo de resíduos de demolição com dimensões espaciais e temporais.

Para analisar a relação entre diversos elemento pode-se usar o SIG, os dados do SIG têm sido utilizados pelos pesquisadores para gerar resultados de diversas formas. Wu et al. (2016) estabeleceram um modelo baseado em SIG. Os mesmos importaram todas as informações coletadas no ArcGIS ou seja, software GIS, com o intuito de ajudar os pesquisadores a prever e avaliar os resíduos de demolição. A abordagem GIS pode favorecer várias formas de expressão, como mapas, tabelas, figuras e animações de simulação, para produzir um resultado geral para a pesquisa (Wu et al., 2016).

A literatura após uma revisão indica que o SIG é uma ferramenta poderosa para analisar a relação espacial. Dessa forma, pesquisadores usaram o SIG para identificar e exibir locais de resíduos ilegais, instruções de fluxo espacial de resíduos, área de armazenamento de resíduos, posição de carga e local da planta de reciclagem.

Com o seguinte pensamento, Ooshaksaraie e Mardookhpour (2011) estabeleceram um sistema baseado em SIG, com uma melhor exibição na localização visual da área de armazenamento de resíduos. Li et al (2005) exibiram a posição de precisão das cargas de material de construção em um mapa GIS.

Seror e Portnov (2018) mapearam todos os sites ilegais de C\&D e áreas de risco elevado em Haifa em mapa GIS. Blengini e Garbarino (2010) ilustram que a cadeia de reciclagem de resíduos de C\&D afeta positivamente a energia e o meio ambiente usando GIS integrado com avaliadores do ciclo de vida.

Sendo um total de 89 dados de fábricas de reciclagem de resíduos C\&D com informações de posição foram importados para o software GIS e exibidos em um mapa GIS. Ding et al. (2018) processo integrado de hierarquia analítica e tecnologias GIS para analisar a melhor localização de aterros sanitários de construção. Com isso, Madi e Srour (2019) localizaram instalações de reciclagem adequadas pelo SIG com intuito de minimizar os custos ambientais e econômicos em um cenário de guerra.

Proposto o conceito de SIG 4D por Tanikawa e Hashimoto (2009) num estudo sobre estoques de material em áreas urbanas. Seguindo a metodologia 4D GIS onde é baseada na tradicional tecnologia 3D GIS com uma dimensão de tempo adicional; o primeiro pode coletar, armazenar, analisar e exibir variação espacial de entidades (Wang et al., 2019). Miatto et al. (2019) utilizaram 4D GIS como forma de estudo para o volume de armazenamento de material de construção e o fluxo espacial de resíduos dinâmico de 1902 a 2007 em Pádua, Itália. 
Tomando como base o trabalho anterior, os mesmos apresentaram uma previsão de potencial de resíduos das atividades de demolição. Por outro lado, um modelo GD 4D foi desenvolvido por Wang et al. (2019) para analisar o processo de metabolismo do material. Sendo aplicado por eles um estudo de caso modelo em Shenzhen, cidade com rápida renovação urbana. Com isso os fluxos de resíduos de C\&D foram analisados.

O modelo proposto de 4D pode produzir claramente o status quo e as futuras tendências da coleta e transporte de resíduos de C\&D. Além disso, o referido modelo ajuda a planejar aterros sanitários da C\&D waste, sendo ele, um método emergente em GIS na gestão de resíduos de C\&D. A atenção adicional será dada a essa disciplina no futuro devido à sua superioridade na análise do fluxo dinâmico de resíduos de C\&D tendo uma dimensão de tempo adicional, com foco especial nas áreas de rápida renovação urbana.

\section{METODOLOGIA}

Para elaboração do trabalho foi realizado pesquisas em artigos científicos pelo método de pesquisa qualitativa, caracterizada por considerar a existência de uma relação dinâmica entre o mundo real e o sujeito, utilizando para tanto o método indutivo (ROBSON, 2000 apud SILVA, 2012, p. 22), respondendo a questões muito particulares.

O meio de investigação foi bibliográfico (JOAN, 207L), que usa o emprego de conhecimentos a partir do uso predominante de levantamento de referência e normas. Nesta pesquisa, foram utilizados bancos de dados como referencial bibliográfico de artigos publicados e normatizados buscando objetivar e embasar esse trabalho. Ainda Vergara (2000), diz que a pesquisa bibliográfica é desenvolvida a partir de material já elaborado, principalmente, constituído, de livros e artigos científicos e é de suma importante para o levantamento de informações básicas sobre os aspectos direta e indiretamente ligados à temática.

A partir das análises de solução adotada na literatura, foi desenvolvido um fluxograma que representasse a estrutura do trabalho (Figura 01).

Figura 1: Fluxograma

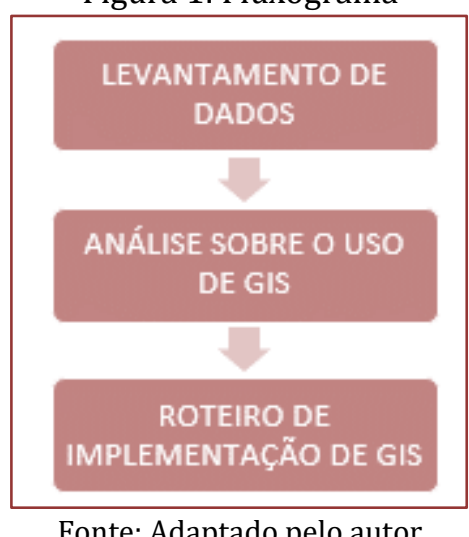

Fonte: Adaptado pelo autor

\subsection{LEVANTAMENTO DE DADOS}

Para fornecer uma compreensão abrangente das aplicações atuais da tecnologia GIS no gerenciamento de resíduos de C\&D, realizou-se uma pesquisa em um dos bancos de dados indexados mais conceituados do mundo o ScienceDirect (http://www-sciencedirect.ez2. periodicos.capes.gov.br/).

A base cientifica contêm numerosos periódicos revisados por pares em todo o mundo e têm alta qualidade (Wu et al., 2014). A pesquisa foi realizada com a palavra chave "C\&D waste and geographic information system", em português sistema de informações geográficas e resíduos de RCD. Aplicando os filtros para um período de publicações de 2020 a 2015 (correspondente aos últimos 5 anos) e para artigos de pesquisa.

Isso resultou em um total de 12.778 resultados, como apresentado na Figura 2. 
Figura 2: Coleta de dados.

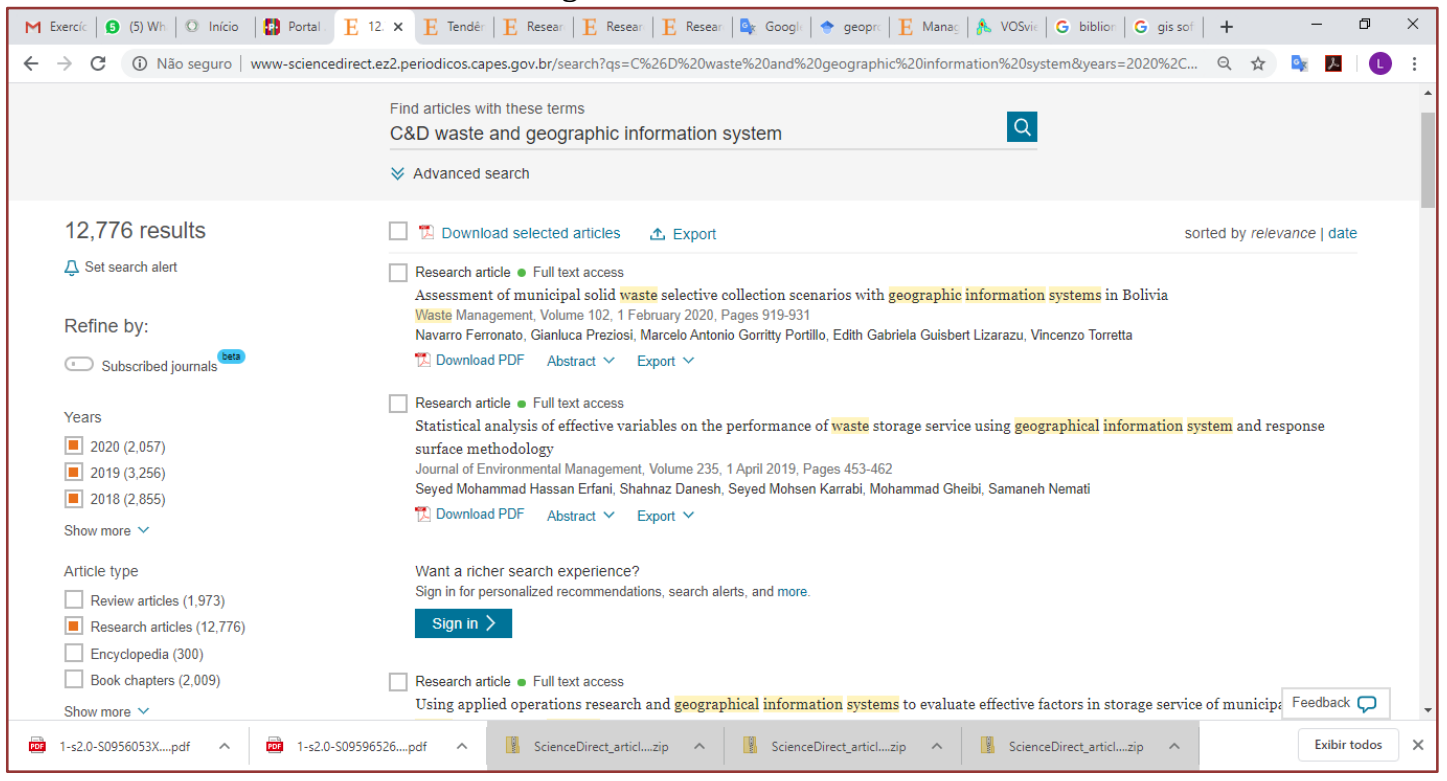

Fonte: acesso em Engineering Village.

\subsection{ANÁLISE SOBRE O USO DE GIS}

Na análise dos artigos foram identificadas e relacionadas informações quanto às motivações para o uso do GIS no gerenciamento de RCD. Foram ainda levantados dados sobre os resultados da aplicação de GIS no gerenciamento de RCD. As informações foram analisadas considerando as particularidades locais onde foram aplicadas. Também foram avaliados os recursos utilizados necessários para a aplicação de GIS no gerenciamento de RCD.

Entretanto, um total de 89 dados de fábricas de reciclagem de resíduos C\&D com informações de posição foram importados para o software GIS e exibidos em um mapa GIS (Ding et al. 2018). Esse processo integrado de hierarquia analítica e tecnologias GIS serve para analisar a melhor localização de aterros sanitários de construção. Com isso, Madi e Srour (2019) localizaram instalações de reciclagem adequadas pelo SIG com intuito de minimizar os custos ambientais e econômicos em um cenário de guerra.

O conceito de SIG 4D por Tanikawa e Hashimoto (2009) enfoca o estudo sobre estoques de material em áreas urbanas. Seguindo a metodologia 4D GIS onde é baseada na tradicional tecnologia 3D GIS com uma dimensão de tempo adicional onde pode coletar, armazenar, analisar e exibir variação espacial de entidades (Wang et al., 2019). Miatto et al. (2019) utilizaram 4D GIS como forma de estudo para o volume de armazenamento de material de construção e o fluxo espacial de resíduos dinâmico de 1902 a 2007 em Pádua, uma cidade Italiana.

Os autores ainda citam apresentaram uma previsão de potencial de resíduos das atividades de demolição. Por outro lado, o modelo GD 4D foi desenvolvido por Wang et al. (2019), para analisar o processo de metabolismo do material, aplicado por eles em um estudo de caso do modelo Shenzhen, que cita a cidade com rápida renovação urbana, analisando os fluxos de resíduos de C\&D.

\section{Roteiro De Implementação De Gis Em Georreferenciamento De Rcd}

Como contribuição, a disseminação do uso de tecnologia no gerenciamento de RCD, nesta fase o estudo propõe um roteiro de implementação da tecnologia. No roteiro foi utilizado o software de GIS de acesso livre mais utilizado, com a finalidade de viabilizar o uso da tecnologia. Todavia, foram identificadas e relacionadas a limitações identificadas nos artigos pesquisados. No roteiro as limitações identificadas foram avaliadas e propostas para evitá-las foram apresentadas. 


\section{Motivação para o uso de GIS no gerenciamento de resíduos}

A crescente urbanização e ocupação desordenada do solo além de aumentar a quantidade de resíduos de demolição e construção torna a escolha de locais adequados ainda mais difícil. Para os autores Huanyu Wu et al. (2016) é importante quantificar, caracterizar e mapear o fluxo dos resíduos gerados para estabelecer medidas de gerenciamento desses resíduos. 0 uso de GIS para estes autores ajuda no levantamento desses parâmetros para o gerenciamento de resíduos de demolição e construção.

Uma vez que esses resíduos não podem ser descartados em aterros sanitários, ou seja não podem ser absorvidos pela natureza, necessitam ser processados. Para o processamento há a necessidade de um local adequado que possibilite tanto a estruturação de uma usina de reciclagem como a logística do transporte desse resíduo. Outra preocupação é quanto aos impactos dessa usina no local. Nadine et al. (2019) buscaram com a tecnologia GIS avaliar pedreiras como possíveis áreas de instalações de processamento de RCD.

Para mitigar os problemas ambientais que a quantidade de RCD gerado causa nos centros urbanos, um estudo da viabilidade do processamento desses resíduos como agregados pode ser uma alternativa. Blengini e Garbarino (2010) analisaram as implicações energéticas e ambientais da cadeia de reciclagem de RCD no norte da Itália, utilizando GIS e ACV (Análise do Ciclo de Vida) para mapear a reciclagem de RCD.

Por mais que as usinas de reciclagem sejam a solução mais apropriada tanto para a gestão do resíduo processado, quanto para a viabilidade econômica da reciclagem de RCD, as usinas móveis despertaram interesse por serem uma das soluções menos citadas em estudos sobre processamento de resíduos. Essa falta de dados sobre a viabilidade econômica dessa solução motivou o estudo de Jingru Li et al (2020). Os autores avaliaram o impacto e os benefícios ambientais associados à reciclagem móvel de resíduos de demolição.

\section{Como usar GIS no gerenciamento de resíduos}

Segundo EPA (2014) “O método GIS poderia lidar com coleta, armazenamento, integração, processamento, análise e apresentá-lo na forma espacial”. Contudo, pode-se identificar, correlacionar e analisar as relações espaciais entre os elementos, permitindo que os formuladores de políticas conduzam análises abrangentes, apresentem tendências visualizadas de desenvolvimento e resultados do projeto, baseado em diversas fontes de informação. Além disso, Malczewski (2004) reforça que este software ajuda a formular os objetivos de planejamento de longo prazo.

No método GIS a construção é digitalizada e georreferenciada sendo considerada uma unidade básica chamada de "Features". Nessa etapa são definidos os limites da construção para o cálculo do volume de resíduo que a construção pode gerar. Para isso é necessário gerar um banco de dados de resíduos com informações no modelo "ER model", que descreve dados e aspectos do resíduo definindo entidades e atributos. Assim, são estabelecidas relações entre essas entidades e as chaves primárias e secundárias, as quais contém características dos resíduos.

Utilizando o módulo ArcMap do ArcGis, Huanyu Wu et al. (2016) geraram resultados, importando banco de dados dos resíduos de acordo com o tipo de construção e estabelecendo uma relação entre as entidades do banco de dados, como: o tipo e a quantidade de resíduo gerado pela construção, o tempo de demolição, o potencial de reciclagem e a capacidade da área de armazenamento.

O uso da tecnologia GIS também permite contribuir para análise de viabilidade econômica e de impacto na instalação de usinas de reciclagem de RCD. Nadine et al. (2019) utilizaram coordenadas geográficas para mapear áreas com potencial para instalação de usina de reciclagem.

Associado a um programa de modelagem da cadeia de gerenciamento de resíduo o GIS contribuiu para avaliar a adequação ambiental de pedreiras para instalação de usinas de reciclagem. 0 modelo simulou um lucro de U\$125 milhões com 20 anos de funcionamento dessas instalações. 0 estudo aponta que 148 pedreiras estão aptas para funcionarem como usinas de reciclagem de acordo com os critérios ambientais.

Para avaliar as implicações energéticas e ambientais da cadeia de reciclagem de RCD o GIS pode ser utilizado juntamente com o método de avaliação do ciclo de vida ACV de acordo com a ISO 14040 (2006) e 14044 (2006). Os dados georreferenciados de usina de reciclagem forma usados para identificar e quantificar distâncias de entregas de agregados reciclados. 
O GIS associado a metodologia LCA (Life Cycle Assessment) provou que as distâncias dos transportes dos agregados reciclados devem aumentar de duas a três vezes antes que os impactos induzidos superem os impactos evitados. Sendo que esses impactos evitados foram maiores que os impactos induzidos o que prova a eco eficiência da cadeia de reciclagem. De forma semelhante Jingru Li et al (2020), utilizaram GIS e a metodologia LCA para avaliar os impactos ambientais e os benefícios associados ao uso de recicladoras móveis. 0 GIS foi usado para determinar de forma precisa as distâncias entre a obra de demolição onde a recicladora móvel estava instalada e os locais de armazenamento dos agregados reciclados.

O impacto ambiental total e os benefícios da reciclagem móvel foram de 0,42 RMB / tonelada (cerca de US \$ 0,06 / tonelada) e 2,6454 RMB / tonelada (cerca de US \$ 0,38 / tonelada), em média, respectivamente.

0 valor médio do impacto ambiental nas etapas de transporte, pré-tratamento, trituração e peneiramento, eliminação de resíduos e entrega de agregados reciclados foi de 0,11 (cerca de US \$0,02 / tonelada), 0,04 (cerca de US \$ 0,01 / tonelada), 0,16 (cerca de US \$ 0,02 / tonelada), 0,10 (cerca de US \$ 0,02 / tonelada) e $0,13 \mathrm{RMB} /$ tonelada (cerca de US \$0,02 / tonelada), respectivamente.

O potencial de aquecimento global (GWP) e a ocupação do solo (OA) foram os principais contribuintes para o impacto ambiental total.

\subsection{PROPOSTA}

Com base no projeto elaborado, indica-se que sejam criados locais adequados para o descarte de resíduos da construção civil. A proposta da Gestão Diferenciada dos RCD pressupõe, na medida em que é da competência das municipalidades a definição da destinação dos resíduos sólidos urbanos, uma ação indutora do poder público, de forma que, mesmo que a alteração da destinação seja iniciada com investimentos públicos, permita a evolução do processo com investimentos privados que cuidem de canalizar os produtos para o consumo nas próprias atividades construtivas geradoras dos resíduos. Será esta a forma de, pela Gestão Diferenciada, avançar na perspectiva do "fechamento do ciclo" para os materiais utilizados nas atividades construtivas, tal como meta já definida nos países da Comunidade Européia (IVBR, [1995]).

Para utilização do GIS na disposição de resíduos de construção e demolição em obras irregulares na cidade de Manaus-AM, propõem-se uma varredura de campo, bem como levantamento in loco para obtenção de dados que serão analisados através da utilização da técnica de georreferenciamento. Técnica essa, utilizada através de capitação de dados dos lotes, já cadastrados pelo IBGE (Instituto Brasileiro de Geografia e Estatística), para que de maneira objetiva e esclarecida, tais informações se entrelacem com precisão.

Podemos citar campos para obtenção de dados dos lotes já oferecidos pelo IBGE como: Códigos de Endereços Postais (CEP), poligonais de bairros, poligonais de conjuntos etc. Visto essas informações obtidas pelo IBGE, elaborou-se uma tabela de banco de dados, juntamente com coordenadas geográficas apuradas através de coordenadas geodésicas com utilização capturada através de datum atual, cujo o nome vem do latim no plural data, que define-se o plano meridional central da terra, bem como Sirgas 2000 (Sistema de Referências Geocêntricos para as Américas) que substituiu o antigo SAD 69, no ano de 2005.

Essas obras informando coordenadas com pontos precisos, capturados por equipamentos gabaritados e profissionais devidamente habilitados responsáveis pela obra, para tal aplicação da atividade e análise de sala técnica, com finalidade de cálculo de volume gerado pela obra $\left(\mathrm{m}^{3}\right)$ juntamente com a destinação dos resíduos de construção e demolição.

Ponto primordial para influência da destinação dos resíduos seriam as centrais de triagem de coleta seletiva, aterro, madeira das escoras, formas de vigas e pilares para produção de carvão, pallet etc. Será necessário atrelar à um ponto da obra, que ao clicar nesse ponto, venha obter informações como: tipo de resíduos, se é madeira, lajota com cimento, bloco cerâmico com cimento, aço e todos os materiais de construção e demolição.

Após detectar os materiais, via análises espaciais, pode-se apontar a central de triagem mais próxima para entrega dos resíduos e traçar uma rota de transporte por meio de pesquisa com coordenadas do ponto da obra. Assim, será reduzido custo com transporte dando mais agilidade na saída de material de RCD. Quantitativo do material transportado pelo caminhão com GPS para rastreamento da rota, evitando desvios que vierem a causar perdas com relação a custos (R\$). 
O SIG (Sistema de Informações Geográficas) ou GIS, será o subsídio para a realização do levantamento. No entanto, poderá ser feito a utilização de Drones, ARP (Aeronave Remotamente Pilotada) para mensuração e cubagem de resíduos. Com isso causará facilidade juntamente com precisão da cubagem dos resíduos de construção e demolição de obras irregulares na cidade de Manaus-AM.

\section{RESULTADOS E DISCUSSÕES}

\subsection{ANÁLISE DE BIBLIOMETRIA}

A análise dos artigos selecionados na base de dados Science Direct, resultou em 15 artigos dos quais quatro abordavam o uso da tecnologia GIS. Porém, dos 15 artigos que usavam a tecnologia, apenas uma utilizavam para o gerenciamento de resíduos de construção. Diante deste resultado foi necessário realizar uma nova busca em outra base de dados, a Engineering Village. A estratégia de busca utilizada foi "GIS" e "CDW". Na Figura 03 está apresentada o resultado da busca na qual pode ser observado que apenas 6 artigos foram encontrados.

Figura 0315: Resultado da busca na base de dados Engineering Village

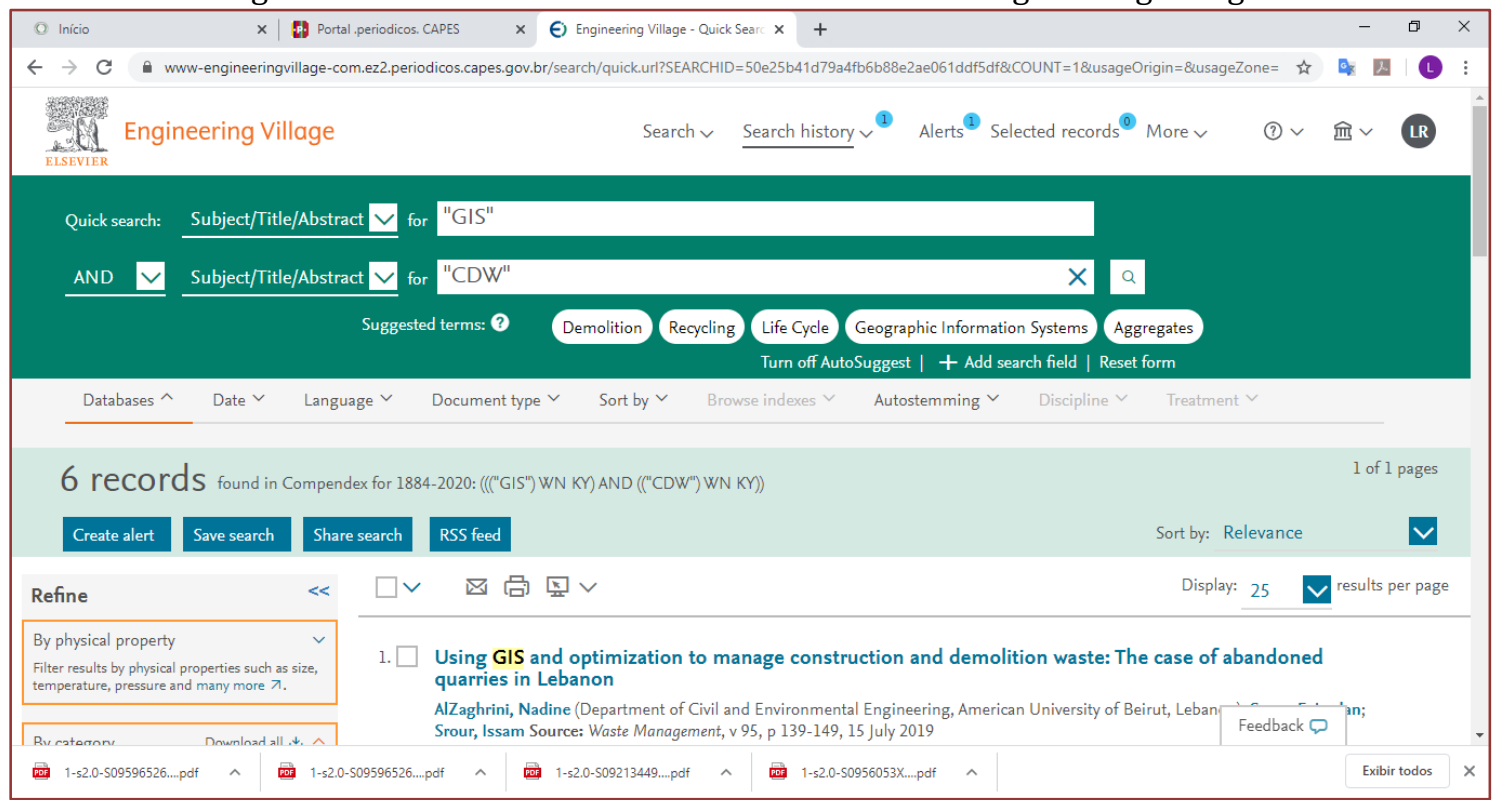

Fonte: Engineering Village.

0 resultado demonstra que as publicações são ainda muito incipientes e apresentam um intervalo longo entre as publicações. A primeira publicação foi em 2010 com dois artigos, a segunda publicação em 2012, e novamente em 2019 e 2020 sendo uma publicação por ano. Das seis publicações encontradas nesta base, apenas três utilizavam a tecnologia GIS para gerenciamento de resíduos de construção e demolição no período dos últimos cinco anos. Portanto, o total de artigos utilizados neste estudo da utilização de GIS no gerenciamento RCD foram quatro.

\section{CONCLUSÃo}

As considerações que se faz com o projeto implantado, é a aquisição da facilidade e praticidade para o trabalho de campo, sendo uma das condições responsivas a precisão da parte técnica. Ademais pode-se obter melhores resultados para os resíduos da construção e demolição, através do mapeamento de obras irregulares, oferecendo amparo para legalização e organização para o plano diretor da cidade de ManausAM, além da eficácia dos projetos de construção civil, apresentando novas informações acerca da reutilização dos materiais descartados.

Considera-se ainda, o sistema de informações geográficas como uma ferramenta que traz a comodidade ao cliente e principalmente ao profissional que estará na ponta da linha atuando em suas atividades. Tal 
sistema pode ser apresentado como projeto para geração de empregos e renda na sociedade, despertando interesses das autoridades que venha a causar resultados benéficos, culminando na continuidade do processo, estando aberta para melhorias e aprimoramento, enquanto a aplicação nas obras.

\section{REFERÊNCIAS}

[1] Al Zaghrini, Nadine Usando SIG e otimização para gerenciar construção e demolição resíduos: o caso de pedreiras abandonadas no Líbano. F. Jordan Srour Issam Srour. Departamento de Engenharia Civil e Ambiental, Universidade Americana de Beirute, Líbano. Departamento de Tecnologia da Informação e Gerenciamento de Operações, Lebanese American University, Líbano, 2019.

[2] ANDREA, Gian. Recursos e gestão de resíduos em Turim (Itália): o papel dos agregados reciclados no mix de oferta sustentável a DISPEA - Departamento de Sistemas de Produção e Economia Empresarial, Politecnico di Torino, Corso Duca degli Abruzzi 24, 10129 Turim, Itália; b CNR-IGAG: Instituto de Geologia Ambiental e Geoengenharia, Corso Duca degli Abruzzi 24, 10129 Turim, Itália; c Departamento de Desenvolvimento Sustentável e Meio Ambiente, Provincia di Torino, Corso Inghilterra 7/9, 10138 Turim, Itália, 2010.

[3] BLENGINI. Recursos e gestão de resíduos em Turim (Itália): o papel dos agregados reciclados no mix de oferta sustentável a DISPEA - Departamento de Sistemas de Produção e Economia Empresarial, Politecnico di Torino, Corso Duca degli Abruzzi 24, 10129 Turim, Itália; b CNR-IGAG: Instituto de Geologia Ambiental e Geoengenharia, Corso Duca degli Abruzzi 24, 10129 Turim, Itália; c Departamento de Desenvolvimento Sustentável e Meio Ambiente, Provincia di Torino, Corso Inghilterra 7/9, 10138 Turim, Itália, 2010.

[4] DUAN, Huabo. Uma abordagem inovadora para gerenciar resíduos de demolição via GIS (sistema de informação geográfica): um estudo de caso na cidade de Shenzhen, China a Escola de Engenharia Civil, Universidade de Shenzhen, Shenzhen 518060, China. Escola de Arquitetura e Ambiente Construído, Centro de Empreendedorismo, Comercialização e Inovação (ECIC), Universidade de Adelaide, Adelaide 5005, Austrália, 2016.

[5] GARBARINO. Recursos e gestão de resíduos em Turim (Itália): o papel dos agregados reciclados no mix de oferta sustentável a DISPEA - Departamento de Sistemas de Produção e Economia Empresarial, Politecnico di Torino, Corso Duca degli Abruzzi 24, 10129 Turim, Itália; b CNR-IGAG: Instituto de Geologia Ambiental e Geoengenharia, Corso Duca degli Abruzzi 24, 10129 Turim, Itália; c Departamento de Desenvolvimento Sustentável e Meio Ambiente, Provincia di Torino, Corso Inghilterra 7/9, 10138 Turim, Itália, 2010.

[6] GUO, Hong. Avaliação do impacto ambiental da reciclagem móvel de demolição resíduos em a Faculdade de Engenharia Civil e de Transportes, Universidade de Shenzhen, Shenzhen, 518060, China. Construção de Internet e Centro de Pesquisa BIM, Universidade de Shenzhen, Shenzhen, 518060, China c Escola de Arquitetura e Ambiente Construído, Universidade de Adelaide, Adelaide, 5005, Austrália d Centro de Empreendedorismo, Comercialização e Inovação (ECIC), Universidade de Adelaide, Adelaide, 5005, Austrália, 2016.

[7] HUANG, Wenke. Uma abordagem inovadora para gerenciar resíduos de demolição via GIS (sistema de informação geográfica): um estudo de caso na cidade de Shenzhen, China a Escola de Engenharia Civil, Universidade de Shenzhen, Shenzhen 518060, China. Escola de Arquitetura e Ambiente Construído, Centro de Empreendedorismo, Comercialização e Inovação (ECIC), Universidade de Adelaide, Adelaide 5005, Austrália, 2016.

[8] HUANYU, WU. Uma abordagem inovadora para gerenciar resíduos de demolição via GIS (sistema de informação geográfica): um estudo de caso na cidade de Shenzhen, China a Escola de Engenharia Civil, Universidade de Shenzhen, Shenzhen 518060, China b Escola de Arquitetura e Ambiente Construído, Centro de Empreendedorismo, Comercialização e Inovação (ECIC), Universidade de Adelaide, Adelaide 5005, Austrália, 2016.

$$
\text { ISO } 14040 \text { (2006) e } 14044 \text { (2006). }
$$

[10] LI, Jingru. Avaliação do impacto ambiental da reciclagem móvel de demolição resíduos em a Faculdade de Engenharia Civil e de Transportes, Universidade de Shenzhen, Shenzhen, 518060, China. Construção de Internet e Centro de Pesquisa BIM, Universidade de Shenzhen, Shenzhen, 518060, China c Escola de Arquitetura e Ambiente Construído, Universidade de Adelaide, Adelaide, 5005, Austrália d Centro de Empreendedorismo, Comercialização e Inovação (ECIC), Universidade de Adelaide, Adelaide, 5005, Austrália.

[11] LIANG, Junlong. Avaliação do impacto ambiental da reciclagem móvel de demolição resíduos em a Faculdade de Engenharia Civil e de Transportes, Universidade de Shenzhen, Shenzhen, 518060, China. Construção de Internet e Centro de Pesquisa BIM, Universidade de Shenzhen, Shenzhen, 518060, China c Escola de Arquitetura e Ambiente Construído, Universidade de Adelaide, Adelaide, 5005, Austrália d Centro de Empreendedorismo, Comercialização e Inovação (ECIC), Universidade de Adelaide, Adelaide, 5005, Austrália, 2016.

[12] Ouyang. Uma abordagem inovadora para gerenciar resíduos de demolição via GIS (sistema de informação geográfica): um estudo de caso na cidade de Shenzhen, China. Escola de Engenharia Civil, Universidade de Shenzhen, Shenzhen 518060, China. Escola de Arquitetura e Ambiente Construído, Centro de Empreendedorismo, Comercialização e Inovação (ECIC), Universidade de Adelaide, Adelaide 5005, Austrália, 2016. 
Engenharia Civil e de Transportes, Universidade de Shenzhen, Shenzhen, 518060, China. Construção de Internet e Centro de Pesquisa BIM, Universidade de Shenzhen, Shenzhen, 518060, China c Escola de Arquitetura e Ambiente Construído, Universidade de Adelaide, Adelaide, 5005, Austrália d Centro de Empreendedorismo, Comercialização e Inovação (ECIC), Universidade de Adelaide, Adelaide, 5005, Austrália, 2016.

[14] WANG, Jiayuan. Uma abordagem inovadora para gerenciar resíduos de demolição via GIS (sistema de informação geográfica): um estudo de caso na cidade de Shenzhen, China a Escola de Engenharia Civil, Universidade de Shenzhen, Shenzhen 518060, China. Escola de Arquitetura e Ambiente Construído, Centro de Empreendedorismo, Comercialização e Inovação (ECIC), Universidade de Adelaide, Adelaide 5005, Austrália, 2016.

[15] ZUO, Jian. Avaliação do impacto ambiental da reciclagem móvel de demolição resíduos em a Faculdade de Engenharia Civil e de Transportes, Universidade de Shenzhen, Shenzhen, 518060, China. Construção de Internet e Centro de Pesquisa BIM, Universidade de Shenzhen, Shenzhen, 518060, China c Escola de Arquitetura e Ambiente Construído, Universidade de Adelaide, Adelaide, 5005, Austrália d Centro de Empreendedorismo, Comercialização e Inovação (ECIC), Universidade de Adelaide, Adelaide, 5005, Austrália, 2016. 


\section{Capítulo 10}

\section{Análise de riscos em imóveis entorno de obras inacabadas: Um estudo de caso na cidade de Manaus- $A M$}

Matheus Souza de Oliveira

Adriana Souza de Oliveira

Luciane Farias Ribas

Sara Santarém

Resumo: Este artigo científico tem como objetivo, analisar os principais riscos que as obras inacabadas dos edifícios do residencial Vernier (localizado no bairro Adrianópolis da cidade de Manaus-AM), ocasiona aos imóveis adjacentes. Para atender a esta proposta, fez-se necessário identificar os principais fatores que acarretam ao embargo ou abandono de obras em geral, verificar a área entorno das obras inacabadas pesquisadas, suas concentrações de residências, comércios, etc. e comparar os riscos do estado atual da construção, apontados pelos moradores e comerciantes locais, com os riscos evidenciados pela literatura vigente. A metodologia consiste em um estudo de caso, utilizando a pesquisa exploratória como meio de coleta de dados, através da aplicação de entrevistas estruturadas com os responsáveis pelos estabelecimentos, referente aos riscos que a obra abandonada e inacabada, ocasiona aos seus respectivos imóveis. Os resultados obtidos nesta pesquisa indicam que os principais riscos identificados com significativos percentuais, conforme o ponto de vista dos responsáveis pelos imóveis, são: ocupação irregular de invasores na construção abandonada; esconderijo para criminosos e usuários de drogas; criadouro e proliferação de pragas; acúmulo de lixo, entulho e dejetos no terreno espalhando mal odor e aumento da vegetação do terreno, gerando transtornos diários e insatisfação da população, além de ocupar um espaço urbano que poderia ser usado como residência, comércio, ou indústria, contribuindo para a sociedade e agregando valor naquela localidade.

Palavras-chave: obras inacabadas, riscos, edifícios. 


\section{INTRODUÇÃO}

Nos últimos 20 anos, o índice de obras inacabadas no Brasil tem aumentado drasticamente. No que se refere as obras públicas, os atrasos e abandono das mesmas está vinculado a questões como má administração e planejamento, contudo, não são unicamente fatores internos como a gestão, que prejudicam uma construção.

Há também fatores externos como: impedimento ambiental, abandono da empresa contratada, restrições financeiras e orçamentárias, motivos técnicos, paralização por fins de segurança do trabalho, pendências quanto a titularidade do terreno, casos de desapropriação, entre outros (FERREIRA; FERREIRA; BRITO, 2017).

Os dados estatísticos e as pesquisas científicas sobre possíveis impactos que essas obras inacabadas, ocasionam para as residências e comércios em seu entorno, são sucintos e escassos. Embora sua importância acadêmica e social seja significativa, pois podem revelar os perigos e transtornos diários que tais imóveis sofrem devido a negligência com o abandono dessas obras.

De acordo com a CBIC (2018) a carência nas atividades de fiscalização e controle das entidades governamentais sob obras abandonadas, desconsideram as várias adversidades geradas por área, pois atuam de modo redundante em relação a legalidade operacional.

Obras abandonadas, podem gerar casos tanto patógenos (criadouros e proliferação de mosquitos e roedores), como insegurança para os moradores quanto aos riscos de desmoronamento, também podem servir como esconderijo para criminosos, usuários de drogas ou até mesmo como ocupação irregular de invasores.

Com o tempo essas situações podem se agravar e prejudicar as residências e estabelecimentos em seu entorno, contribuindo também para uma poluição visual da área, e proporcionando uma sensação de insegurança para quem trafega próximo a área da construção inacabada, além da desvalorização dos imóveis e os riscos de endemias, afetando a grande densidade populacional naquela localidade.

A presente situação de construções incompletas e abandonadas, assim como seus eventuais riscos para a sociedade, possibilitou a execução deste estudo de caso, para investigar a seguinte questão: Quais são os principais riscos que as obras inacabadas do edifício residencial Vernier, ocasionam aos imóveis adjacentes?

O objetivo deste artigo será, analisar os principais riscos que as obras inacabadas do edifício residencial Vernier (localizado no bairro Adrianópolis da cidade de Manaus-AM), ocasiona aos imóveis adjacentes. E para alcançar este objetivo especificamos os seguintes critérios: Identificar os principais fatores que acarretam ao embargo ou abandono de obras em geral; Verificar a área entorno da obra inacabada pesquisada e suas concentrações de residências, comércios e etc.; Comparar os riscos do estado atual da construção, apontados pelos moradores e comerciantes locais, com os riscos evidenciados pela literatura vigente.

Ferreira, Ferreira e Brito (2017), define obras inacabadas como uma obra em andamento, contudo ainda não integralizada que por justificativas financeiras, judiciais ou embargos, tornaram seu prosseguimento transitoriamente inerte. Uma obra abandonada está associada a uma paralização de prazo considerável o suficiente, constatando que a construção já perdeu seu papel ou que encontrar-se em estado de degeneração.

Construções abandonadas, são espaços abertos em áreas urbanas e (normalmente) inocupadas, tornandose um local perigoso quanto a perspectiva das pessoas que circulam nestas localidades, e são poucos os que se arriscam a explora-los. Geralmente elas são evitadas por quem trafega em seus arredores, apesar de se referirem a estes espaços com recordações e expectativas para seu futuro, mas que em nada suprime atualmente (BRITO-HENRIQUES; CAVACO; LABASTIDA, 2019).

Tanto obras de caráter público quanto privado apresentam determinados fatores, por exemplo: o extenso período de realização, os altos gastos financeiros, o ambiente desvantajoso e diversas áreas de serviços do mercado com diferentes encargos nas atividades complexas da construção, o que torna a obra, um local com alto nível de risco (BELTRÃO, 2017). 


\section{FUNDAMENTAÇÃO TEÓRICA}

\subsection{OBRAS PÚBLICAS E PRIVADAS INACABADAS}

O campo da construção civil é uma área em que se incide grandes transações financeiras, que são necessárias para concretização de uma diversidade de obras, sejam elas de pequeno ou grande porte. Consequentemente, devido à grande responsabilidade a ser aplicada, esse setor torna-se um dos mais sujeitos a riscos, decorrente de um grupo de razões distintas (ALTE, 2017).

A construção civil executa obras de natureza pública e privada. A diferença entre uma e outra está no fator da gestão, onde as obras privadas são empreendidas integralmente por dirigentes de empresas particulares, sem a intervenção de governantes e políticos, como também não necessitam adotar planos de projeto governamental, tornando-as mais independentes neste seguimento do que obras públicas, tendo em vista na maior parte dos casos a geração de lucro (BELTRÃO, 2017).

Geralmente, elas podem caracterizar-se inacabadas por conta de abandonos consequentes de superfaturamento, fraudações e desvios de materiais ou até mesmo defeitos de projeto ou de má execução.

Já as obras públicas, segundo o mesmo autor, são realizadas em total harmonia com os princípios adotados pelo governo em questão, tornando-as exclusivamente associadas aos projetos governamentais, e financiadas com dinheiro público que são apurados pela arrecadação de impostos e taxas, cobradas da população.

O Tribunal de Contas da União - TCU (2013), define as obras públicas como sendo quaisquer construções, reformas, recuperações ou melhorias, que foram financiadas e realizadas pelo Poder Público, para servirem a população de forma direta ou indiretamente.

Para tanto, o mesmo órgão público compreende que as obras públicas incompletas, são as que não estão aptas para iniciar suas atividades, seja por falta de acabamento estrutural que impede sua função, ou por não ter um alvará de funcionamento.

Portanto, nas obras públicas a atuação da política é sempre empregue de forma muito intensiva fazendo com que o orçamento, o encaminhamento das dotações e os procedimentos exigidos, estejam em absoluta sincronia com as pretensões do governo atuante. Dessa forma, a gestão das obras públicas pode ser efetuada.

\subsection{PRINCIPAIS CAUSAS NA INTERRUPCÃO DAS OBRAS}

O Brasil apresenta muitas situações de obras não finalizadas, pode-se abordar desde rodovias que fazem conexão com outros estados, mas que não dão suporte total a motoristas que trafegam nela, assim como os centros esportivos com acabamentos pendentes por falta de verba do governo, ou aeroportos inativos por questões de alterações em projetos e atos de corrupção na administração (OLIVEIRA, 2016).

Segundo Coutinho e Santos (2019), diariamente a sociedade acompanha através das mídias, redes sociais e outras formas de transmitir comunicação, episódios de escândalos envolvendo atos de corrupção, alguns comumente relacionados a eventos anteriores que afetam a população até os dias atuais, e ainda estabelecem muitos debates políticos, crises econômicas, financeiras.

Situações desta natureza desequilibram o processo de desenvolvimento do mundo globalizado. Conforme os anos se passam, somos capazes de testemunhar que as modificações dos centros urbanos em desenvolvimento no decorrer da história das cidades, produziram uma grande quantidade de estruturas não finalizadas e em estado de abandono.

$\mathrm{Na}$ época atual, as pessoas contam com mais tecnologia e edificações modernas, mas ainda se deparam com antigas construções abandonadas, dessa forma as sociedades do passado acabam deixando imóveis no qual podem vir a se tornar tanto uma herança cultural, quanto um transtorno social (MACEDO, 2019).

A execução de uma obra de um edifício residencial em determinada área da cidade, pode ocasionar vários impactos positivos ao passo que atrai um grupo populacional, estimulando assim, um processo por mudanças em relação a infraestrutura local (SANTOS, 2018).

Entretanto, no caso de haver a probabilidade da não solidificação da obra, como no caso do residencial Vernier, a mesma dará origem a algo prejudicial, causando inúmeros problemas e impossibilitando que a área ocupada possa ser aproveitada para outras finalidades. 
O mesmo autor citado anteriormente, ressalta que as obras em deterioração podem implicar na questão da saúde pública, uma vez que abandonadas por longo tempo e sem a devida manutenção, tornando essas áreas uma espécie de berço para endemias, contribuindo para a proliferação de insetos venenosos e animais peçonhentos.

A relação da corrupção na administração com empreendimentos não finalizados é um assunto que tem ganhado mais visibilidade. A corrupção tem se manifestado desde os tempos arcaicos, visto que é motivo de diversos debates entre a população, pois esse termo se relaciona com o fato de as pessoas testemunharem frequentemente episódios que envolvam improbidade e deslealdade comumente sendo praticados por entidades governamentais nas suas incumbências (OLIVEIRA, 2016).

Portugal (2017) esclarece que apesar das despesas públicas gastas com construções sejam disponibilizadas para consulta no portal do governo federal, as técnicas referentes a fiscalização do andamento das obras não aparentam demonstrar a segurança e a prevenção da corrupção na gestão, nem aos interesses governamentais quanto a execução desses planejamentos, que em alguns momentos, são estipulados em benefício de interesses políticos.

Segundo Garcia (2016) em novembro de 2016 foi estabelecida a Comissão especial de obras inacabadas (CEOI), com o propósito de realizar uma análise baseada em levantamentos das obras inacabadas e abandonadas em todo o Brasil. Esta comissão atuou no período de tempo de um ano, com o propósito de reconhecer as obras, criando uma lista, para então investigar as causas por trás da não finalização dessas obras e os possíveis responsáveis por suas paralizações.

\subsection{ANÁLISE DE RISCOS EM OBRAS}

Risco é um termo que sempre esteve presente na sociedade, estabelecendo uma série de fatores negativos. Conforme o dicionário da língua portuguesa, o conceito de risco, abrange a viabilidade ou possibilidade de um perigo. Cada propósito ou decisão que vir a ser tomada, envolve implicações, isto é, encontra-se um risco aplicado na perspectiva de um acontecimento desfavorável (ALTE, 2017).

Isso significa que, por mais determinada que a circunstância executada se apresente nos padrões estabelecidos de segurança, essa por vez pode acarretar em um desenvolvimento futuro de riscos, no entanto, para eliminar o risco bastaria que fosse verificada as diversas ocasiões de exposição ao perigo a longo prazo, evitando assim tais perigos e contratempos (LEINFELDER, 2016).

Conforme uma determinada área é explorada para realização de um estudo de caso, a análise de riscos pode gerar múltiplos objetivos, e conforme seu objetivo, ou o meio em que se encontra, uma análise da área de riscos pode ser constituída de diversas formas.

Por exemplo, é possível classificar como fator de risco para moradores e suas respectivas residências: a falta de um saneamento básico, ocupações de imóveis em solos acidentados, obras abandonadas e perto de igarapés, ou qualquer construção que apresente irregularidade na sua ocupação. (ALVES; KUHNEN; CRUZ, 2019).

Sempre que um fenômeno desastroso atingir uma área vulnerável ou um grupo de indivíduos, é natural que danos e prejuízos sejam assunto de debate entre a população. Os danos se relacionam as perdas humanas, tendo como base, a quantidade de sujeitos afetados, a perda de bens matérias associados ao imóvel destruído e prejuízos ambientais que estão relacionados ao solo e aos recursos hídricos (PRANDEL et al., 2019).

A ligação existente entre os principais danos, instabilidade e perigo é onde institui-se o risco, sendo ele definido como a possibilidade da ocorrência de uma ameaça, onde a mesma possa vir a prejudicar os indivíduos presentes, acarretando impactos negativos.

Por essa razão, segundo Leinfelder (2016) em um certo evento imprevisto na análise de riscos, presume que, se tal evento aconteça, deve-se averiguar com base no ponto de vista das pessoas e nos registros históricos. Dessa forma podemos dizer que o termo analisar, refere-se à investigação e estudo de um determinado objeto de forma meticulosa e com riqueza de detalhes. 


\subsection{CONSEQUÊNCIAS DA INTERRUPÇÃO DAS OBRAS}

No decorrer dos anos a dengue se transformou em um grande problema na questão da saúde pública, pois sua adaptação ao clima quente e úmido, especialmente em países com climas tropicais, produzem condições propícias para a multiplicação do mosquito que transmite essa doença, e o mesmo está cada vez mais ocupando espaço urbano (FLÔR, 2015).

De acordo com Leal (2016) apud Carmo e Neto (2017), existe uma elevação epidêmica ocorrendo no Brasil, no presente momento relacionado ao mosquito Aedes Aegypti, responsável pela transmissão da Dengue, Zika e Chikungunya, e este inseto continuará com a propagação dessas doenças, se não for tomada as devidas medidas com base nas análises do Departamento de Vigilância de Doenças Transmissíveis do Ministério da Saúde.

Com base no ponto de vista deste mesmo autor, as grandes edificações abandonadas que apresentarem áreas externas propensas ao acúmulo de água parada, acabam por tornar-se pontos de proliferação de mosquitos e criadouro de pragas, podendo agravar-se devido à falta de fiscalização e o acesso restrito as essas obras, por parte de seus proprietários.

De acordo com os autores Carmo e Neto (2017), uma das peculiaridades que uma construção abandonada apresenta é a não conservação apropriada de sua parte estrutural. A carência de reparos regulares em um edifício pode tornar a obra suscetível a danos, no que se refere a sua estrutura, podendo ocasionar altos riscos a moradias entorno de sua área, levando em conta seu risco de desmoronamento, tal construção necessitará da verba pública para seu cuidado.

Com relação aos riscos presentes na ação de uma ocupação irregular em um imóvel inacabado, os autores Anitelli e Tramontano (2016) esclarecem que o motivo mais comum que estimula a população mais pobre a realizar ocupações em edifícios abandonados, se dá exatamente pelo fato de o imóvel estar abandonado.

De outra maneira, o que dá mais ênfase a essa atitude são situações em que o proprietário do empreendimento não realiza os procedimentos e determinações estabelecidos por lei, na obra. Coincidentemente essas ocupações impulsionam a intervenção dos poderes públicos a tomar partido a respeito do assunto. Contudo, o que aparentemente se demonstra no argumento dos representantes públicos é uma contraposição em relação ao ponto de vista dos indivíduos mais pobres (ANITELLI; TRAMONTANO, 2016).

Já os autores Filho e Rivelini (2016), esclarecem que em relação ao código civil, as empresas responsáveis pelas construções de suas obras, sejam elas públicas ou privadas, devem atribuir uma garantia de segurança e solidez por no mínimo cinco anos, visto que, o que realmente se sucede é uma desconsideração por intermédio da administração pública em requerer os serviços das construtoras, que assumem a obrigação da executar as obras no período de tempo limite, ocasionando obras mal planejadas e sem qualidade.

\subsection{IMPACTO DAS OBRAS INACABADAS NA CIDADE DE MANAUS}

Em Manaus é possível encontrar diversas construções em situação de abandono apenas visitando algumas zonas da cidade, como no caso das áreas no centro da cidade, onde se encontram obras não finalizadas em que, na maioria das vezes, partiram de execuções por iniciativas privadas, e com algumas dessas obras servindo de abrigo para mais de 100 pessoas (JUNIOR, 2019).

Existem grandes edificações inacabadas situadas a partir do bairro Adrianópolis, conforme demonstrado na Figura 4. Onde são encontrados além do edifício Residencial Vernier (objeto de estudo da pesquisa), situado no ponto 1 destacado em vermelho no mapa, outros três empreendimentos inacabados:

0 residencial Ville Dijon, no ponto 2, situado próximo ao conjunto Abílio Nery, no qual encontram-se dois prédios em estado de abandono. No ponto 3 uma edificação com quatro andares, no Loteamento Vila Americana, que permanece parado a mais de trinta anos. E no ponto 4 uma obra abandonada de cinco andares, na Vila Municipal Operária (SCHMIDT, 2013). 


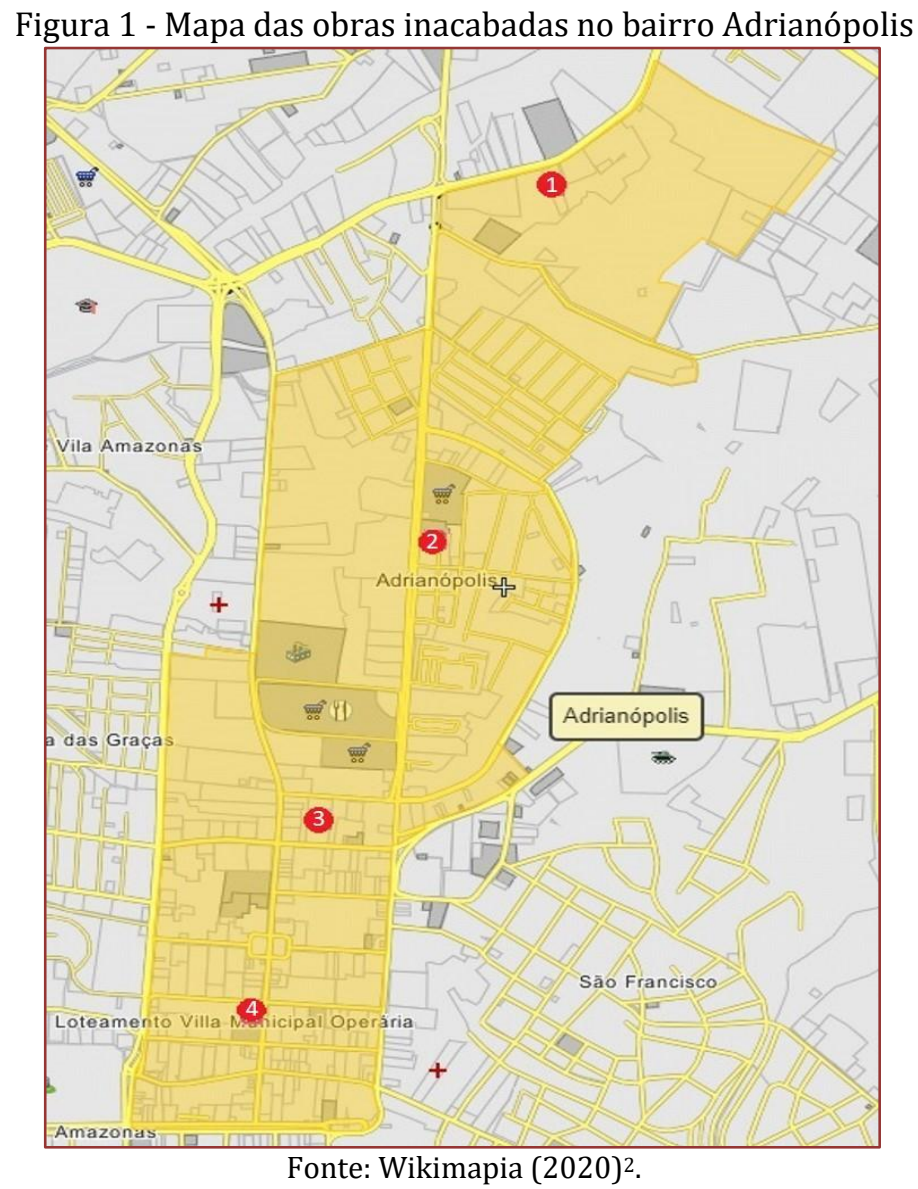

De acordo com o código de obras e edificações do município de Manaus, o abandono de construções por motivos instituídos dentro da lei $003 / 2014$, artigo 41, podem ocasionar punições sujeitas de multas com valores correspondentes a $\mathrm{R} \$ 1.089,50$ sendo equivalente a 10 UFMs (valor da Unidade Fiscal do Município) aplicadas pelo Poder Executivo municipal. (MANAUS, 2014)

0 valor de 1 UFM será de $\mathrm{R} \$ 108,95$ cuja classificação entrou em vigor em 2020 com base no decreto $\mathrm{N}^{\circ}$ 4705 de 2019. (MANAUS, 2019).

\subsection{1 ÓRGÃO FISCALIZADOR DE OBRAS ABANDONADAS}

O Instituto Municipal de Planejamento Urbano - IMPLURB, é o órgão responsável pela realização da fiscalização e intimação de prédios e propriedades em condições de abandono na cidade de Manaus. A sua criação teve o propósito de dar o prosseguimento às atribuições e competências da antiga Empresa Municipal de Urbanização (URBAM), revogada pelo decreto no. 6.744, de 14 de abril de 2003 (SOUZA, 2017).

O IMPLURB atua mediante aos seus principais objetivos sendo eles, o progresso urbano da cidade, no que se refere a estruturação, ordenação da ocupação do solo e a padronização em relação à utilização dos espaços urbanos, apresentados na Lei no. 687 de 13 de dezembro de 2002 (IMPLURB, 2002).

O IMPLURB se tornou oficialmente o órgão executivo na cidade de Manaus no ano de 2009, começando a exercer o gerenciamento no Sistema Municipal de Planejamento Urbano e a estabelecer políticas de gestão e progresso urbano, a partir do Plano Diretor Urbano Ambiental de Manaus (IMPLURB, 2020).

De acordo com Márcio Alexandre, assessor jurídico do IMPLURB, os proprietários de obras inacabadas possuem a responsabilidade de cuidar de suas propriedades, para garantir a prevenção de acidentes e conservar a saúde da população nas redondezas da obra. Ele afirma que a maior dificuldade em relação a essas obras é a identificação do dono encarregado da construção.

\footnotetext{
2 Disponível em: <https://wikimapia.org/> Acesso em mai. 2020.
} 
O IMPLURB intervém em obras abandonadas efetuando intimações através de denúncias feitas pela população ou por um agente fiscalizador da instituição, para ser feita a análise do terreno e os impactos que a obra causará aos estabelecimentos ao seu redor.

O proprietário é notificado e recebe uma advertência para realizar a limpeza do terreno e seu fechamento com um período de tempo determinado pelo IMPLURB, sendo o dono da obra passível de multa pelo não cumprimento do prazo estipulado.

\subsection{A FALIDA ENCOL E SUA LIGAÇÃO COM RESIDENCIAL VERNIER}

A Encol foi uma empresa Brasileira estabelecida em 1961, atuando na área da construção civil pelo seu fundador, o engenheiro Pedro Paulo de Souza, na capital de Goiás, sendo uma das maiores construtoras do ramo imobiliário no Brasil. 0 seu processo de falência iniciou na metade da década de 90 , por dificuldades administrativas motivadas pela gestão insegura da diretoria, declarando sua falência definitiva em 1999 (DANGOT, 2017).

Segundo o autor, a eventual falência da construtora gerou uma grande repercussão na mídia com o levantamento da dúvida, sobre o modo que o mercado imobiliário atuava de forma geral, investigando os empréstimos concedidos pelas organizações financeiras para as instituições dirigentes, assim como sua proteção jurídica.

Esses fatores geraram uma desconfiança por partes dos consumidores, que pretendiam investir em unidades autônomas, pois não tinham garantia de segurança do imóvel. 0 acontecimento ocorrido na Encol gerou muitos prejuízos, que se prorrogaram até os dias atuais.

Estabilizada em 66 cidades do Brasil e expandida em outros países, a Encol contava com a mão de obra de 23 mil funcionários e executou a construção de aproximadamente 100 mil habitações. Com sua falência decretada em 1999, a empresa gerou um prejuízo estimado em $\mathrm{R} \$ 2,025$ bilhões, e dezenas de empreendimentos inacabados deixados para seus 42 mil adquirentes. (OLIVEIRA, 2016).

O advogado Hamilton Quirino Câmara explica em seu livro, integrando o caso da Encol que parcelava o pagamento dos credores em até 5 anos, condição essa que fazia a empresa bancar suas próprias vendas, pois o valor total desembolsado para execução de imóveis não tinha retorno na conclusão do apartamento (CÂMARA apud, OLIVEIRA, 2016).

Entre os edifícios abandonados da Encol encontrasse o residencial Vernier, situado na avenida Efigênio Salles do bairro Adrianópolis, Zona Centro sul de Manaus.

A obra era um empreendimento realizado pela antiga Encol, e baseava-se na construção de dois edifícios de 11 pavimentos, com quatro moradias em cada andar, sendo o primeiro para estacionamento de veículos, somando assim, um conjunto de 40 apartamentos em cada edifício, com 80 unidades no total (IMPLURB, 2020).

Porém a obra abandonada encontra-se atualmente com apenas um edifício de 11 andares inacabado e o segundo edifício ao seu lado, com apenas três andares levantados, sem alvenaria executada.

\subsubsection{MEDIDAS LEGISLATIVAS DE PROTEÇÃO E GARANTIAS}

Com as edificações abandonadas provenientes da empresa Encol, o mercado imobiliário sofreu uma grande transformação na sua área legislativa, criando assim planos para impossibilitar que os prejuízos como os provenientes da Encol, transcorram no decorrer dos anos. Dessa forma foi desenvolvida a medida provisória n. 2.221 em setembro de 2001, e logo após estabeleceu-se o Patrimônio de afetação em agosto de 2004 (EYNG; PEIXOTO, 2016).

A medida provisória é composta por três segmentos, sendo o primeiro para habilitar como patrimônio de afetação, uma incorporação imobiliária, o segundo sobre a forma que o patrimônio de afetação se estabeleceria no empreendimento, e o terceiro segmento se tratava das utilidades da afetação, nesse caso seriam as ações que os compradores recorreriam, se porventura as atividades da obra fossem interrompidas excedendo os trinta dias, ou pela ocorrência de falência da incorporadora (DOTTA, 2018). 
Os autores Eyng e Peixoto (2016) esclarecem que o patrimônio de afetação é um tipo de mecanismo judiciário cuja a responsabilidade é conceber ligações contratuais, possibilitando uma distinção patrimonial e formando assim, um compromisso com a incorporadora além de prevenir um eventual descumprimento das atribuições jurídicas propostas no andamento do empreendimento, a fim de obter uma melhor relação entre o incorporador do negócio e seus adquirentes.

Consequentemente, a afetação engloba todo agrupamento patrimonial em que se constitui a incorporação imobiliária, estabelecendo uma separação de direitos e deveres a um determinado empreendimento para que se tenha menos riscos, do início ao término da obra para seus compradores. Este método faz com que cada obra executada pela incorporadora tenham um investimento individual, não havendo nenhuma ligação com as outras unidades que estiverem em andamento (GUERINI; MARCHESE; VIEIRA, 2019).

É evidente que o patrimônio de afetação proporciona diversos benefícios aos adquirentes do imóvel, no entanto, escolher um empreendimento com a afetação aderida não estabelece uma total segurança para o adquirente no decorrer da obra, isso porque a afetação gera restrições a serem seguidas no planejamento do imóvel, dispondo do orçamento com base no valor ajustado para compra da unidade, mas diminuindo consideravelmente o risco do empreendimento (DOTTA, 2018).

\section{METODOLOGIA}

\subsection{CARACTERIZAÇÃO DA PESQUISA}

A metodologia adotada deu-se, inicialmente, por meio de pesquisas bibliográficas, utilizando artigos científicos, livros, monografias, dissertações, teses, documentos oficiais e sites confiáveis, para constituir a base teórica necessária ao tema proposto, elucidando todos os aspectos que o envolvem, e desenvolvendo os objetivos específicos, estipulados anteriormente.

Segundo Gil (2017) quanto aos objetivos, trata-se de uma pesquisa exploratória, que visa elucidar casos específicos, mantendo certa flexibilidade quanto ao seu planejamento e execução em campo, seja esta através da aplicação de questionários, entrevistas ou como uma observação sistematizada.

Conforme o mesmo autor elucida, quanto aos procedimentos metodológicos, optou-se por um estudo de caso, cuja classificação é a mais adequada para a resolução desta pesquisa, pois envolve análise detalhada de um ou poucos objetos físicos ou sociais, como pessoas, grupos ou instituições, permitindo um conhecimento preciso acerca do que se propôs a investigar cientificamente.

A pesquisa seguiu três etapas de execução, a primeira etapa consiste em levantamento da localização da construção inacabada, que compõe o presente estudo de caso, assim como a seleção da amostra dos estabelecimentos em seu entorno, para aplicação das entrevistas.

A segunda etapa trata-se da aplicação do questionário em campo, com todos (se possível), os responsáveis dos imóveis selecionados, com o objetivo de coletar dados quantitativos e as informações dos riscos em potencial que afetam seus estabelecimentos.

E a terceira etapa corresponde a tabulação dos dados e formulação de gráficos, para posterior análise e interpretação dos resultados de pesquisa, assim como atingir o objetivo geral estabelecido inicialmente, concluindo o presente estudo.

\subsection{POPULAÇÃO E AMOSTRA}

A população da pesquisa, são todos os estabelecimentos (comerciais, industrias ou moradias) em um raio de 100 metros de distância, inclusos na circunferência da Figura 1 a seguir, totalizando aproximadamente 45 estabelecimentos, entorno da obra inacabada e em estado de abandono, intitulada como Edifício Residencial Vernier.

Localizado na Avenida Efigênio Salles, bairro Adrianópolis, zona centro-sul da cidade de Manaus, sob as seguintes coordenadas geográficas: latitude $3^{0} 5^{\prime} 22^{\prime \prime}$, longitude $60^{\circ} 0^{\prime} 22^{\prime \prime} \mathrm{W}$. Esta obra foi selecionada, do mesmo modo que a população pesquisada, por critério de acessibilidade. 
Figura 1 - Localização da população entorno dos edifícios

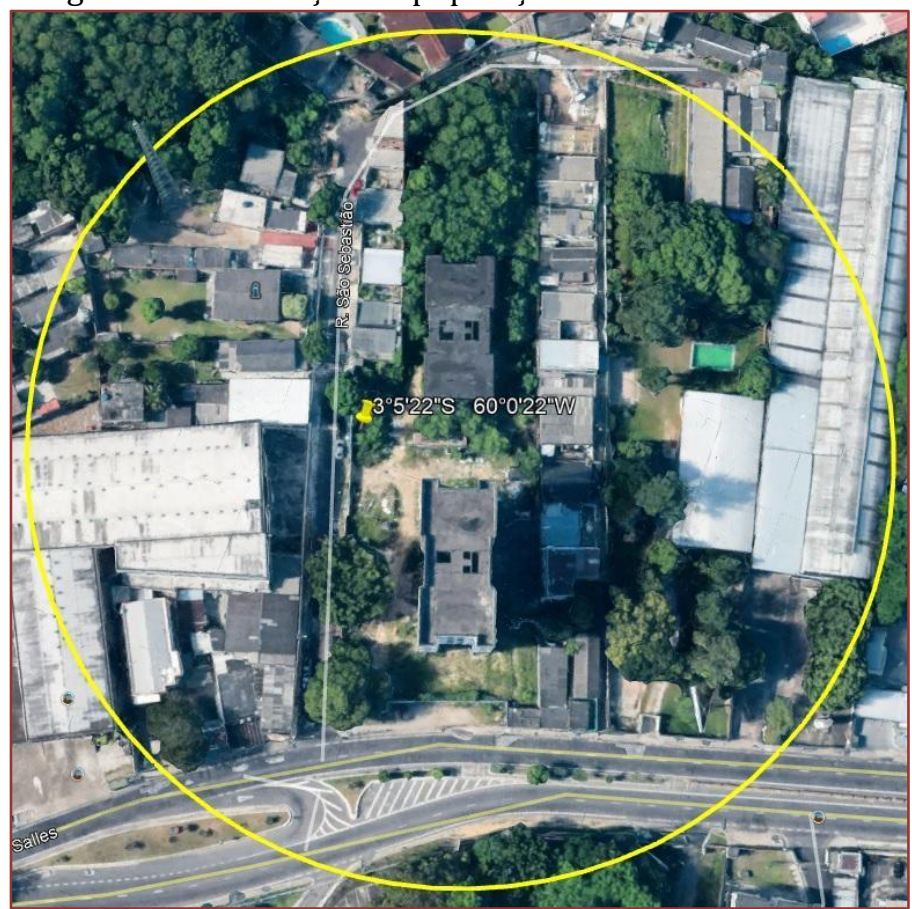

Fonte: Google Earth (2020)3.

A amostra equivale a $56 \%(n=45)$ da população formada, selecionadas por critério de proximidade com os dois edifícios inacabados e, portanto, deduz-se que são os estabelecimentos mais afetados pelo abandono da obra. Segue abaixo, na Figura 2, um croqui do quarteirão, com os dois edifícios inacabados, representados no centro da imagem e destacados pela cor cinza, assim como os demais estabelecimentos selecionados e devidamente identificados, conforme a localização real dos mesmos:

Figura 2 - Croqui de localização

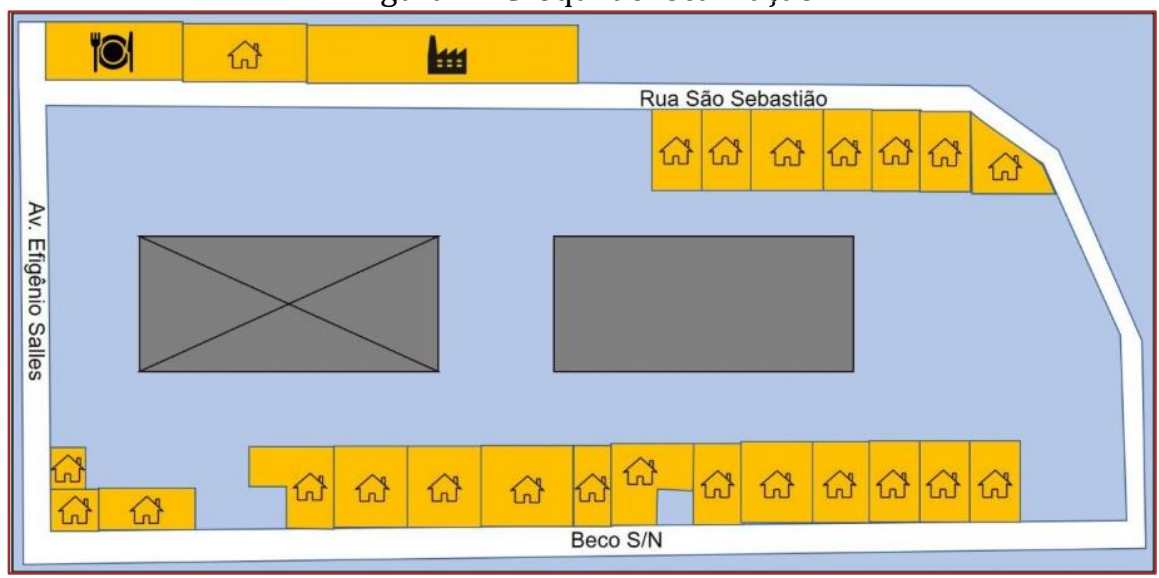

Fonte: Autoria Própria (2020)

\subsection{CRITÉRIOS DE INCLUSÃO E EXCLUSÃO}

Como critério de inclusão da pesquisa, dentre os diversos estabelecimentos próximos do edifício residencial Vernier (população), foram selecionados 25 imóveis (amostra), considerando que estes são os principais afetados devido a maior proximidade com os edifícios inacabados. A realização da entrevista será com um morador por cada imóvel, presente no momento da entrevista, na faixa etária acima dos 18 anos.

\footnotetext{
${ }^{3}$ Disponível em: <https://earth.google.com/web/> Acesso em mai. 2020.
} 
Em caso de comércios ou indústrias inclusos na pesquisa de campo, a entrevista será aplicada a algum colaborador presente no estabelecimento, que tenha acima de um ano de vivência no local, desempenhando seu ofício, e com o consentimento prévio do proprietário do imóvel.

Como critério de exclusão da pesquisa, durante este processo não será coletado informações pessoais dos entrevistados ou dados de identificação dos imóveis, visto que tais perguntas são impertinentes ao objetivo da pesquisa, e podem causar estranheza, desconfiança, interferências em suas decisões, ou até mesmo recursar-se a responder as perguntas e dispensar o entrevistador.

\subsection{INSTRUMENTO DE COLETA}

0 instrumento de coleta estruturado deu-se em forma de questionário contendo 06 perguntas com abordagem quantitativa-descritiva, elaboradas pelo autor desta pesquisa. São perguntas fechadas com alternativas fixas de respostas, para ser aplicadas como forma de roteiro em uma entrevista com os responsáveis pelos imóveis da amostra selecionada.

\subsection{PROCEDIMENTOS DA COLETA}

O período adotado para coleta de dados (entrevistas), referente aos riscos que a obra inacabada (residencial Vernier) ocasiona aos estabelecimentos em seu entorno, foi na quinta-feira do dia 04 de junho de 2020, entre as 15:00hrs e 17:00hrs da tarde, participando de forma voluntária cerca de $60 \%(n=15)$ dos estabelecimentos selecionados na amostra da pesquisa.

Dessa maneira deu-se os processos metodológicos necessários a fim de levantar os resultados específicos, conforme questionário de perguntas no roteiro das entrevistas para análise, demostradas através de gráficos, com suas respectivas interpretações descritas no próximo capítulo desta pesquisa, intitulado como: resultados e discussão.

\section{RESULTADOS E DISCUSSÃO}

A entrevista foi realizada presencialmente no quarteirão do residencial Vernier, com os responsáveis pelos imóveis localizados entorno das obras inacabadas, cuja amostra integrava 25 imóveis. Deste total, somente $60 \%(n=15)$ participaram, devido a outra parcela de responsáveis não estar presente no momento da entrevista.

As perguntas foram conduzidas de forma imparcial pelo entrevistador, e respondidas voluntariamente pelos entrevistados que expuseram suas opiniões sem interferência. Com as repostas obtidas através do questionário estruturado, foi produzido os gráficos, a seguir, com suas respectivas análises interpretativas, que compõe os resultados da pesquisa.

A primeira questão da entrevista aborda há quanto tempo eles residem ou trabalham no imóvel, e foi identificado (conforme ilustra o gráfico 1), que $72 \%(n=11)$ dos entrevistados residem a 20 anos ou mais naquele local, e alguns destes relataram acompanhar desde o início das construções dos 2 edifícios nos anos 90, os últimos movimentos dos funcionários na obra do residencial, assim como seu completo abandono por anos, até a data atual.

Tal observação sob a trajetória das obras ao longo do tempo é válida, pois os edifícios estão com as obras paralisadas há 21 anos, visto que, a construtora Encol teve sua falência decretada em 16 de março de 1999, sendo considerada na época a maior construtora do país, com 11 projetos em andamento na cidade de Manaus, deixando 31 edifícios inacabados, e dentre estes os 2 edifícios do residencial Vernier, e aproximadamente mil clientes desamparados (NETO, 1999). 
Gráfico 1 - Tempo em que os entrevistados residem ou trabalham no imóvel

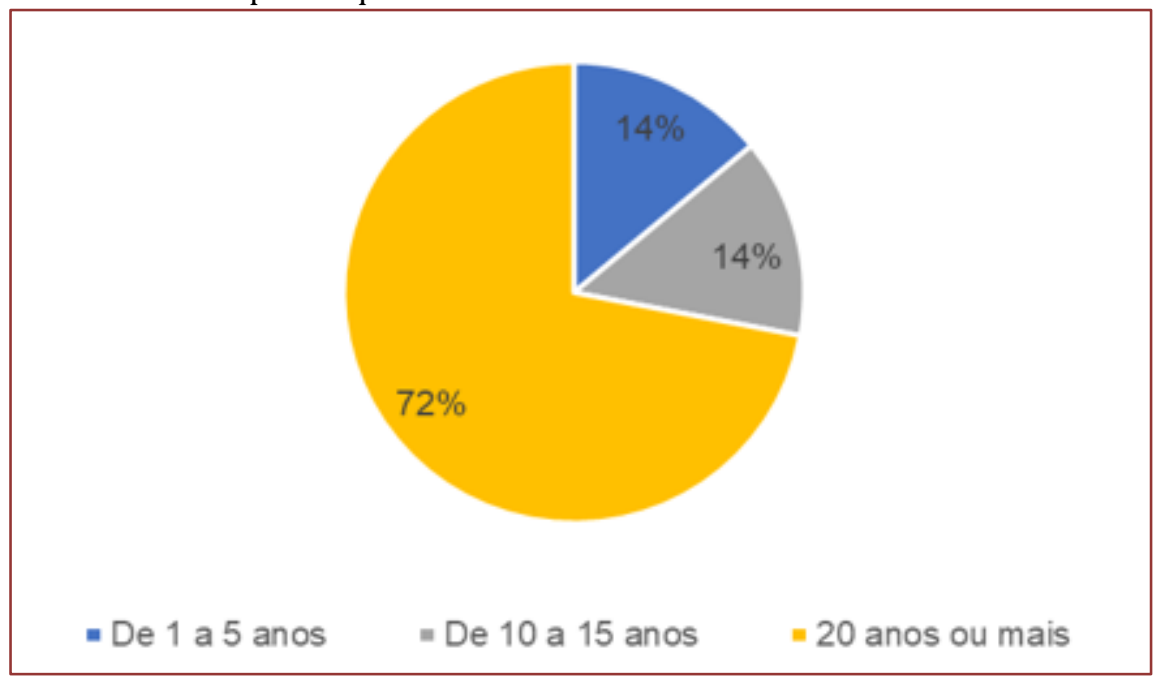

Fonte: Autoria Própria (2020).

De acordo com os dados coletados, somente $14 \%(n=2)$ dos entrevistados residem entre 10 e 15 anos, os outros $14 \%(\mathrm{n}=2)$ moram ou trabalham entre 1 a 5 anos no imóvel, nenhum dos entrevistados $(\mathrm{n}=0)$ indicou residir ou trabalhar entre 5 a 10 anos naquele local, portanto este dado não consta no gráfico acima apresentado.

Grande parte dos entrevistados demostraram propriedade em relatar suas percepções acerca de todos os desdobramentos da construtora Encol e suas obras abandonadas.

A questão 2 da entrevista, é composta pelo grau de satisfação em relação as condições atuais das obras do residencial Vernier, dispondo como alternativas de respostas: ótimo, bom, regular, ruim ou péssimo. Os resultados compõem o gráfico 2 , a seguir:

Gráfico 2 - Grau de satisfação sobre as condições atuais das obras

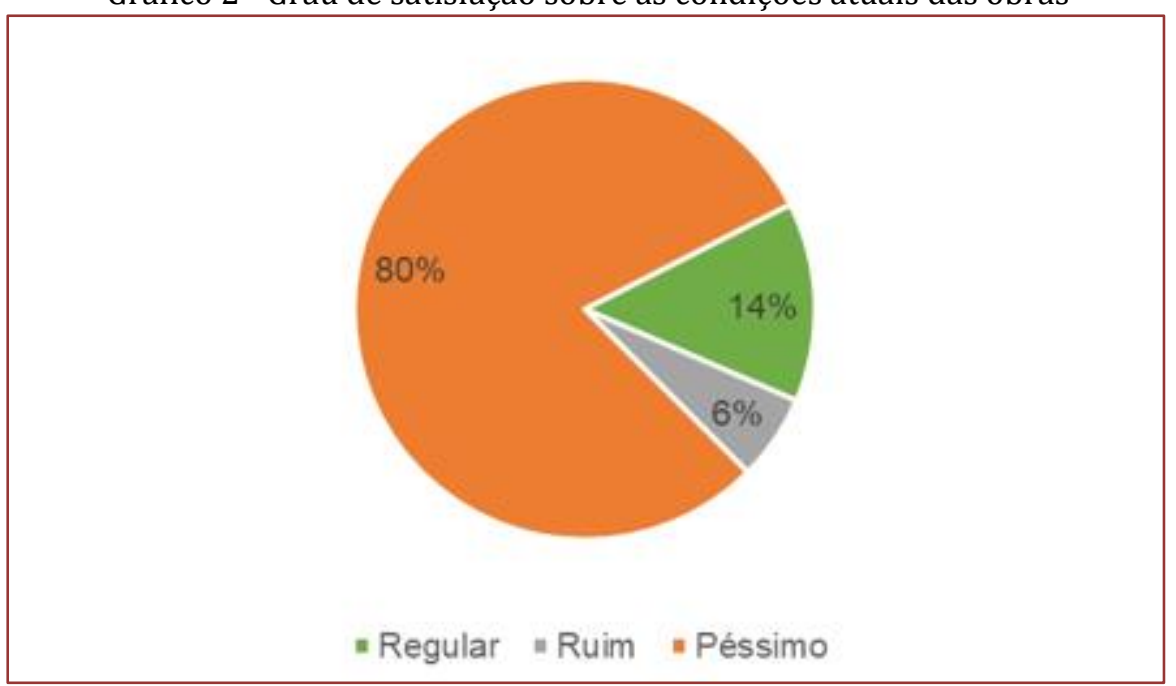

Fonte: Autoria Própria (2020).

Quanto ao grau de satisfação, 80\% (n=12), dos entrevistados consideram que as condições atuais do residencial Vernier estão péssimas, $14 \%(n=2)$ as consideram como regular e somente $6 \%(n=1)$ dos entrevistados a consideram ruim. Nenhum dos entrevistados $(n=0)$ consideram as condições atuais das obras como bom ou ótimo, portanto, essas alternativas não constam no gráfico acima apresentado.

Observou-se que a insatisfação expressiva dos entrevistados é atribuída diretamente a falta de manutenção devida no terreno do residencial Vernier, conservando um mato alto que cobre os muros, e árvores com raízes que invadem os imóveis, provocando rachaduras nas paredes das residências. 
Na terceira questão da entrevista afirma-se que as obras do residencial Vernier estão abandonadas a um longo período de tempo, e atribui como opções de resposta, concordar com um sim, ou discordar da afirmação com um não.

Da mesma forma a questão 4 indaga se os edifícios inacabados do residencial Vernier, ocasionam algum tipo de prejuízo ao imóvel do entrevistado, contendo as mesmas opções de resposta da questão anterior (sim ou não).

O posterior gráfico 3 corresponde a tais respostas, tanto da terceira como da quarta questão, pois coincidentemente, as duas obtiveram a mesma porcentagem de respostas, em suas respectivas alternativas.

Gráfico 3 - Opinião quanto ao abandono e prejuízos gerados pelas obras

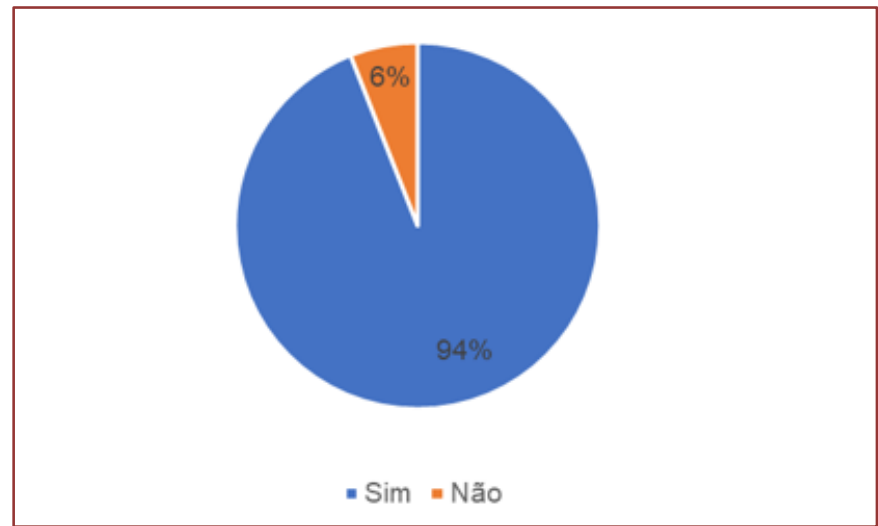

Fonte: Autoria Própria (2020).

Conforme o gráfico acima representa visualmente a opinião dos entrevistados, expressivos 94\% (n=14) concordaram com a alternativa "sim", enfatizando que as obras inacabadas do residencial Vernier estão realmente abandonadas a um longo período de tempo.

Esta mesma porcentagem de entrevistados, afirma que estas obras ocasionam algum tipo de prejuízo ao seu imóvel. E somente 6\% $(n=1)$ dos entrevistados discordaram destas duas considerações, com a alternativa "não".

A questão 5, cuja análise é essencial para os resultados dessa pesquisa, corresponde aos principais fatores de riscos em potencial, que afetam o imóvel do entrevistado, em relação as obras abandonadas do residencial Vernier, e por consequência, foram selecionados os 9 fatores de riscos mais comuns na literatura vigente, pertinentes a construções abandonadas, que estão descritas nas opções de respostas, conforme exibe o gráfico 4 , a seguir:

Gráfico 4 - Os principais fatores de riscos que afetam o imóvel

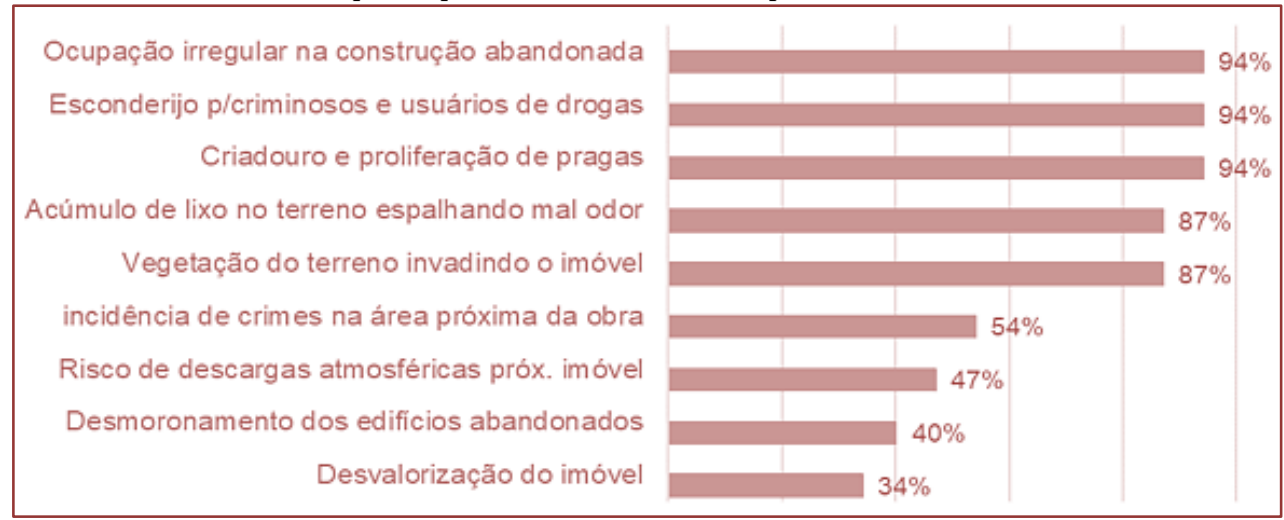

Fonte: Autoria Própria (2020). 
Os riscos que obtiveram 94\% $(n=14)$ de confirmação dos entrevistados como fator real e presente no cotidiano daquele local, correspondem a: ocupação irregular de invasores na construção abandonada; esconderijo para criminosos e usuários de drogas; criadouro e proliferação de pragas (como mosquitos, roedores, animais peçonhentos e etc.).

Segundo os entrevistados, casos de moradores clandestinos nos edifícios inacabados são recorrentes, constantemente denunciados e despejados pela força tática policial.

De acordo com a avaliação do Programa das Nações Unidas para o Desenvolvimento (2013) apud Carmo e Neto (2017), o Brasil apresenta um alto índice de roubos com 527,2 casos a cada 100.000 indivíduos, fazendo com que o país fique em terceiro lugar nesta proporção com base nos 18 países estudados da américa latina.

Edifícios abandonados ou áreas localizadas em setores urbanos sem ocupação oferecem uma enorme vantagem para estes dados no Brasil, visto que nestes cenários de inexistência da segurança e ocupações inapropriadas, estão espalhadas em diversas áreas, possibilitando fácil acesso aos desocupados e favorecendo a criminalização nas ruas.

Houve também relatos de foragidos da justiça encontrados e apreendidos no local, e sempre surgem novos casos, pois o local possui fácil acesso, também é possível encontrar eletrodomésticos, colchão e utensílios de cozinha espalhados pelo terreno do local, em estado de deterioração.

0 acúmulo de lixo, entulho e dejetos no terreno espalhando mal odor, igualmente ao aumento da vegetação do terreno que transpõe os muros invadindo as residências, calçadas e vias públicas, atinge $87 \%(\mathrm{n}=13)$ dos imóveis entrevistados.

As condições atuais das edificações em relação aos impactos ambientais, estão totalmente contra as normas propostas pelo plano diretor de Manaus, em especifico na lei complementar $\mathrm{n}^{0} 2$, de 16 de janeiro de 2014, art. 72, referente aos regulamentos para as regras de uso e apropriação do solo ressaltando no item VI "o controle das atividades e dos empreendimentos potencialmente poluidores e degradadores do ambiente, que provoquem risco à segurança ou incômodo à vida urbana” (MANAUS, 2014).

Com base em Martins et al. (2019), o descarte de materiais inapropriados a céu aberto pode ocasionar em um alastramento de diversas doenças, além de servirem como abrigo mosquitos, baratas e roedores contribuindo para a poluição do solo e do lençol freático por consequência de resíduos do lixo que possam produzir chorume.

Alguns moradores disseram que periodicamente fazem uma arrecadação em dinheiro para pagar os custos de um profissional que corte a vegetação alta no perímetro interno do residencial Vernier próximo do muro, que está tão alta onde mal consegue-se visualizar o segundo edifício inacabado com 3 andares. A Figura 3 abaixo, ilustra bem este cenário.

0 muro especificado anteriormente, também é fruto da colaboração financeira dos moradores, eles se organizaram para arrecadar fundos para a construção do muro com o propósito de diminuir a frequência de criminosos e invasores além de proteger a região dos fundos de seus imóveis.

Figura 4 - Vista aérea do segundo edifício do residencial Vernier

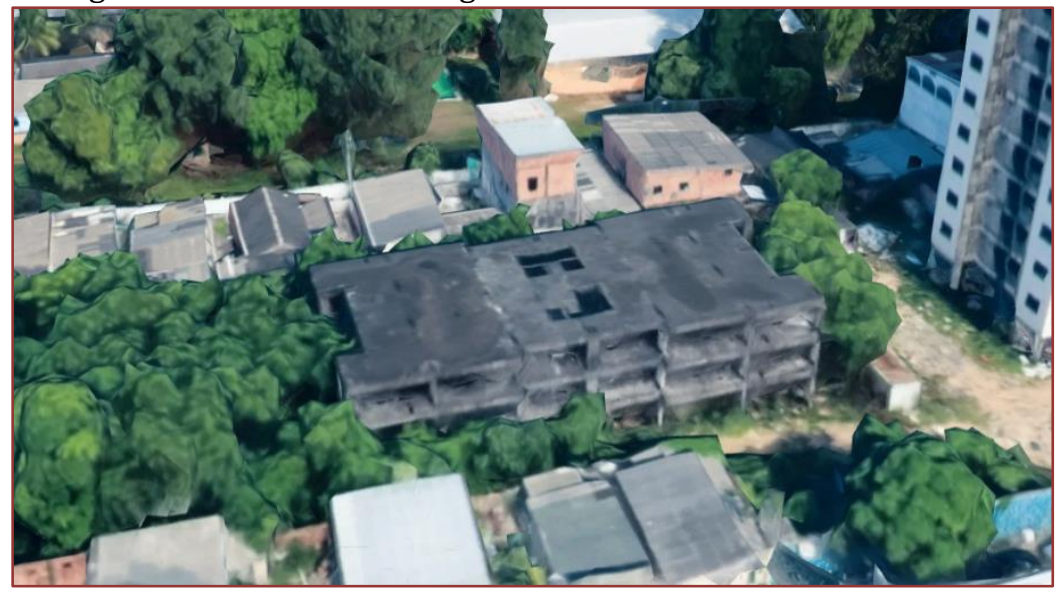

Fonte: Google Earth $(2020)^{4}$.

4 Disponível em: <https://earth.google.com/web/> Acesso em mai. 2020. 
No que corresponde ao aumento na taxa de incidência de furtos e assaltos na área próxima da obra, 54\% $(n=8)$ dos entrevistados asseguraram que este fator de risco perdura, e causa insegurança a uma parcela dos moradores, outros discordam e acreditam que devido a movimentação da avenida Efigênio Salles, e o patrulhamento ocasional da polícia, raramente isto ocorre.

Os riscos de descargas atmosféricas (raios) próximo do imóvel, foi considerado por 47\% (n=7) dos entrevistados, devido ao primeiro edifício com 11 andares não possuir um sistema de proteção contra essas descargas atmosféricas (SPDA). E prédios, assim como qualquer estrutura alta, atrai este tipo de fenômeno natural.

Marinho (2018) esclarece que, ainda que tenhamos um vasto conhecimento e tecnologias a nossa disposição, as descargas atmosféricas são eventos imprevisíveis, não podendo ser controlado, sendo necessário a utilização de procedimentos que sejam capazes de minimizar ou restringir os seus impactos a

sociedade.

Em vista disso, um método muito conveniente utilizado também como instrumento de pesquisa e estudos voltados para aprimorar seu desempenho nestes eventos, são os chamados sistemas de proteção contra descargas atmosféricas (SPDA). Este sistema tem o potencial de oferecer segurança as construções e aos indivíduos que trafegam nas aéreas urbanas, podendo evitar riscos de incêndios aos imóveis, explosões e demais impactos provocados pelas descargas elétricas (MARINHO, 2018).

0 perigo de desmoronamento dos edifícios em cima dos imóveis, conforme visão dos responsáveis que foram entrevistados, somente $40 \%(n=6)$ temem este acontecimento, os outros responsáveis alegam que o edifício foi construído utilizando concreto usinado, assim possuindo resistência a intempéries por um longo período de tempo.

Os engenheiros responsáveis por essas construções abandonadas, podem ser acusados e penalizados criminalmente na ocorrência do desabamento de um destes edifícios, pois trata-se de uma contravenção em não adotar providências diante do estado de perigo que a obra inacabada venha oferecer atentando contra a vida dos moradores, suas integridades físicas e seus patrimônios. (KRUBNIKI; PEREIRA, 2019).

No que tange a desvalorização dos imóveis próximos ao residencial, 34\% (n=5) dos entrevistados supõem que sim, ocorreu tal perda de valor dos seus imóveis no mercado imobiliário, no entanto, os demais declararam que devido à proximidade dos imóveis com a principal avenida do bairro Adrianópolis, a obra em nada afeta seu valor imobiliário.

Gráfico 5 - 0 imóvel é próprio ou alugado para o entrevistado

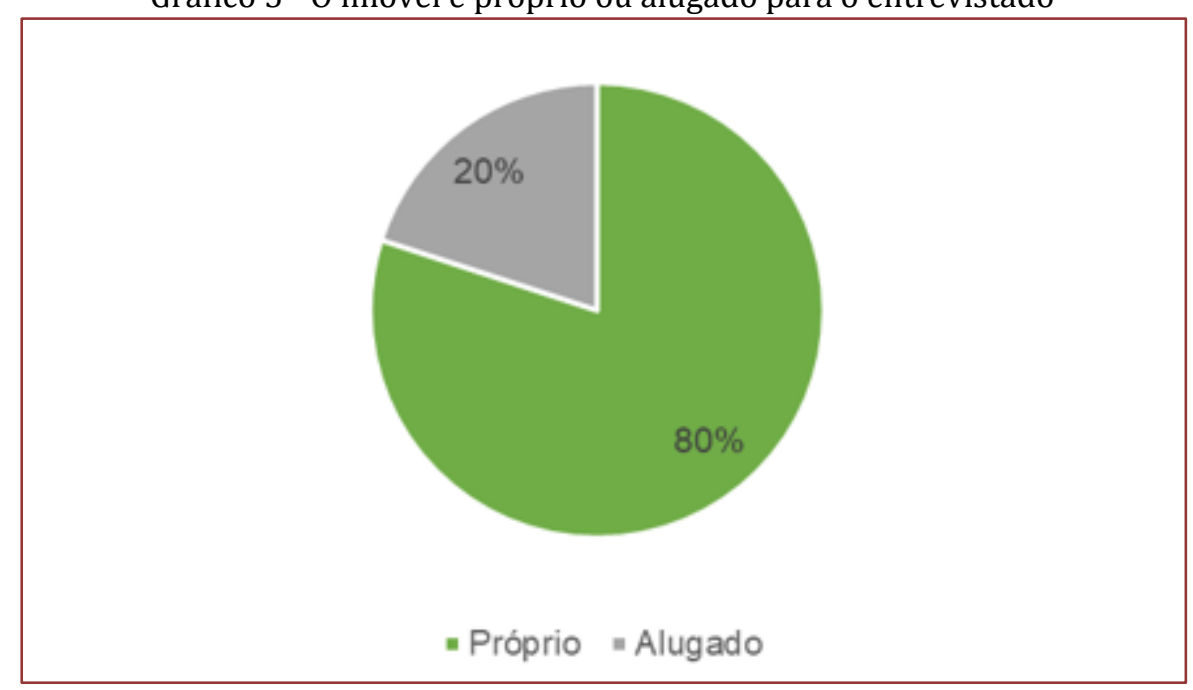

Fonte: Autoria Própria (2020)

Segundo o gráfico acima, o imóvel é de total propriedade para $80 \%(n=12)$ dos moradores entrevistados, enquanto $20 \%(n=3)$ alugam os imóveis daquela localidade.

Quanto aos principais danos ambientais, sociais, econômicos e de segurança verificados por Guimarães et al. (2012), comumente encontrados em obras abandonadas, que impactam o bem estar da população e dos estabelecimentos em seu entorno, estão: a ocupação irregular de moradores; local propício para tráfico de 
drogas e prostituição; vegetação densa na área externa; acúmulo de água parada; criadouro de animais peçonhentos e vetores de doenças; acúmulo de resíduos; falta de iluminação nas vias próximas e perigo de desabamento da construção inacabada.

O comparativo destes riscos comuns, citados anteriormente, com os riscos identificados na presente pesquisa, se encontram na tabela 1 a seguir, ordenados por riscos associados.

Tabela 1 - Comparativo dos riscos da literatura com os riscos da pesquisa

\begin{tabular}{|c|c|c|}
\hline Riscos associados & Riscos da literatura vigente & Riscos da pesquisa. \\
\hline Água, animais e vegetação & $\begin{array}{l}\text { - Vegetação densa na área } \\
\text { externa; } \\
\text { - Acúmulo de água parada; } \\
\text { - } \quad \text { Criadouro de animais } \\
\text { peçonhentos e vetores de doenças. }\end{array}$ & $\begin{array}{l}\text { Vegetação do terreno } \\
\text { invadindo calçadas e vias públicas; } \\
\text { Criadouro e proliferação de } \\
\text { pragas (mosquitos, roedores e etc.). }\end{array}$ \\
\hline Uso do solo e resíduos & $\begin{array}{l}\text { Acúmulo de resíduos; } \\
\text { Ocupação irregular de } \\
\text { moradores. }\end{array}$ & $\begin{array}{l}\text { Acúmulo de lixo, entulho e } \\
\text { dejetos no terreno espalhando mal } \\
\text { odor; } \\
\text { " Ocupação irregular de } \\
\text { invasores na } \\
\text { abandonada. }\end{array}$ \\
\hline $\begin{array}{l}\text { Vulnerabilidade social e desastres } \\
\text { naturais }\end{array}$ & $\begin{array}{l}\text { Local propício para tráfico } \\
\text { de drogas e prostituição; } \\
\text { Falta de iluminação nas vias } \\
\text { próximas; } \\
\text { construção inacabada. }\end{array}$ & $\begin{array}{l}\text { Esconderijo para } \\
\text { criminosos e usuários de drogas; } \\
\text { Desvalorização do imóvel; } \\
\text { Maior incidência de furtos e } \\
\text { assaltos na área próxima da obra; } \\
\text { Desmoronamento dos } \\
\text { edifícios em cima do imóvel; } \\
\text { Risco de descargas } \\
\text { atmosféricas (raios) próximo do } \\
\text { imóvel. }\end{array}$ \\
\hline
\end{tabular}

Fonte: Autoria Própria (2020).

Observa-se que em todas as questões realizadas por meio desta entrevista, as respostas apresentaram números expressivos quanto aos aspectos insatisfatórios e danosos, revelando assim, que mais da metade dos indicadores estão condizentes com a realidade apresentada naquele ambiente, contudo, na visão dos entrevistados, nem todos os fatores de riscos citados prejudicam todos os imóveis, alegando que depende da proximidade do imóvel com os edifícios, quanto mais perto, mais riscos, o que é logicamente pertinente naquelas circunstâncias.

Assim como cada construção tem suas peculiaridades, no que se refere a terreno, material utilizado e destinação de uso, seja como residência, hospital, escola, fábrica, comércio e etc. Portanto, nem todos os fatores de riscos serão cabíveis em uma obra abandonada.

\section{CONCLUSÃo}

Constatou-se através do desenvolvimento desta pesquisa que o impacto de uma obra inacabada e abandonada sobre os imóveis próximos de tal área, geram transtornos diários e insatisfação da população, além de ocupar um espaço urbano que poderia ser usado como residência, comércio, ou indústria, contribuindo para a sociedade e agregando valor naquela localidade.

Os principais riscos identificados com significativos percentuais, conforme o ponto de vista dos responsáveis pelos imóveis, entorno dos dois edifícios residenciais inacabados, são: Ocupação irregular de invasores na construção abandonada; Esconderijo para criminosos e usuários de drogas; Criadouro e proliferação de pragas; Acúmulo de lixo, entulho e dejetos no terreno espalhando mal odor e aumento da vegetação do terreno.

Os moradores adotaram medidas de caráter paliativo contra esses riscos, o que torna necessário a investigação de medidas mais eficazes a fim de sanar os riscos apresentados. Este propósito serve como uma recomendação para outro estudo de caso, pois existem poucas iniciativas científicas publicadas sobre essa temática em questão. 
Algumas providências básicas, reivindicando ações como dedetização da área, retirada da vegetação e entulho do local, foram realizadas por meio de petições públicas, mas infelizmente ainda não foram atendidas.

Houve tentativas de entrar em contato com os órgãos de fiscalização, solicitando informações detalhadas sobre a vida útil dos edifícios, quem são seus atuais proprietários ou se existe alguma possibilidade de retomada e recuperação dessas construções, mas não se obteve nenhuma resposta até a data de conclusão deste estudo.

Esta pesquisa proporcionou uma reflexão sobre lugares abandonados, visto que são comuns nos centros urbanos da cidade de Manaus. Outra questão é a importância em preservar as edificações sejam elas públicas ou privadas, como uma espécie de dever em uma sociedade moderna que zela por um ambiente seguro e saudável, caso contrário torna-se uma mazela econômica, social e ambiental.

\section{REFERÊNCIAS}

[1] ALTE, Felipe Costa de. Análise de Riscos em Obras Públicas Interrompidas. Dissertação (Mestrado em Engenharia Civil - Especialização em Construções) Faculdade de Engenharia da Universidade do Porto, Portugal, 2017.

[2] ALVES, Roberta Borghetti; KUHNEN, Ariane; CRUZ, Roberto Morais. Escala de apego à moradia em área de risco. Rio de Janeiro: Saúde Debate, vol. 43, n. especial, p. 137-151, dez. 2019.

[3] ANITELLE, Felipe. TRAMONTANO, Marcelo. Abandonados por uns, ocupados por outros: Edifícios de apartamentos no centro paulistano. Revista Brasileira de Estudos Urbanos Regionais. Vol. 18, n. 1, p.77-91, jan./abr. 2016.

[4] BELTRÃO, Leandro Modesto Prates. Priorização de Riscos de Obras Públicas por Meio do Processo de Análise Hierárquica Fuzzy. Dissertação (Mestrado em Engenharia Civil - Especialização em Estruturas e Construção Civil) Faculdade de Tecnologia da Universidade de Brasília, Distrito Federal, 2017.

[5] BRITO-HENRIQUES, Eduardo. CAVACO, Cristina. LABASTIDA, Marta. Ruínas e Terrenos Vagos: Explorações, Reflexões e Especulações. Lisboa-PT: Centro de estudos Geográficos da Universidade de Lisboa, 2019.

[6] CARMO, Luane Susan Bueno; NETO, Tomaz de Aquino Lopes. Recuperação em Obras Abandonadas. Dissertação (Bacharel em Engenharia Civil). UniEvangelica, Goiás, 2017.

[7] CBIC - Câmara Brasileira da Industria da Construção. Impacto Econômico e Social da Paralisação das Obras Públicas. Brasília-DF: COP, abril. 2018.

[8] COUTINHO, Francisco Pereira. SANTOS, Ruth. ATAS do I Curso Sobre o Combate a Corrupção na Contratação Pública. Lisboa-PT: CEDIS, Centro de I\&D sobre direito e sociedade. Maio, 2019.

[9] DANGOT, Samantha. A Compra e Venda e a Permuta na Incorporação Imobiliária (estudo de caso). Dissertação (Mestrado em Direito). Fundação Getúlio Vargas, São Paulo, 2017.

[10] DOTTA, Júlia. O Patrimônio de Afetação na Recuperação Judicial. Monografia (Bacharel em Ciências Jurídicas e Sociais - Departamento de Direito Privado e Processo Civil, Universidade Federal do Rio Grande do Sul), Porto alegre, 2018.

[11] EYNG, Carlos Eduardo; PEIXOTO, Fabiano Hartmann. Patrimônio de Afetação: Segurança na Aquisição de Imóveis Incorporados. Revista de Direito da Cidade. Vol. 08, n. 1, p.93-111, Jan. 2016.

[12] FERREIRA, Ana Carla dos Santos Anunciação; FERREIRA, Bianca dos Santos Anunciação; BRITO, Renata da Silva. Obras públicas Inacabadas: as principais causas que resultam em desperdício de dinheiro público. Universidade Federal Fluminense, Rio de Janeiro, 2017.

[13] FILHO, Osmar Xavier de Barros; RIVELINI, Adrieli Renata Barriquelo. Vícios Construtivos em Obras Públicas: um estudo de caso em 27 obras. Revista UNINGÁ review (online). Vol. 28, n. 2, p.16-23. Out/Dez. 2016.

[14] FLÔR, Cristiano dos Santos. O Enfrentamento da Dengue como Foco da Saúde em um Município do Interior do RS. Especialização em Gestão de Organização Publica em Saúde Palmeiras das missões, 2015.

[15] GARCIA, Gustavo. Há 22 mil obras inacabadas no Brasil, diz presidente de comissão do Senado. 2016. Disponível em: <http://g1.globo.com/politica/noticia/2016/11/ha-22-mil-obras-inacabadas-no-brasil-dizpresidente-de-comissao-do-senado.html> Acesso em: 26 março 2020.

[16] GIL, Antônio Carlos. Como Elaborar Projetos de Pesquisa. 6. Ed. São Paulo: Editora Atlas S.A. 2017.

[17] GUERINI, Eduardo; MARCHESE, Augusto; VIEIRA, Ricardo Stanziola. Efetivação das Políticas Públicas de Habitação com Base no Patrimônio de Afetação: Análise da incidência do Instituto nos Registros de Imóveis no Caso Emblemático do Balneário Camboriú/SC. Int. Públ. - IP, Belo Horizonte, ano 21, n.118, p.151-186. nov./dez. 2019. 
[18] GUIMARÃES, Solange T. de Lima. et al. Gestão de Áreas de Riscos e Desastres Ambientais. Rio Claro: IGCE/UNESP/RIO CLARO, 2012.

[19] IMPLURB, Instituto Municipal de Planejamento Urbano. Lei Ordinária N ${ }^{0} 687$ de 13 de Dezembro de 2002. Disponível em: <https://leismunicipais.com.br/a/am/m/manaus/lei-ordinaria/2002/68/687/lei-ordinaria-n-6872002-cria-o-instituto-municipal-de-planejamento-urbano-implurb-e-da-outras-providencias $>$. Acesso em: 13 junho 2020.

[20] IMPLURB, Instituto Municipal de Planejamento Urbano. Sobre a IMPLURB: Nossa História. Disponível em: <http://implurb.manaus.am.gov.br>. Acesso em: 18 abril 2020.

[21] JUNIOR, Waldick. Fantasmas de Concreto: prédios abandonados assombram Manaus há 20 anos. 2019. Disponível em: <https://d.emtempo.com.br/amazonas/183151/fantasmas-de-concreto-predios-abandonadosassombram-manaus-ha-20-anos> Acesso em: 09 maio 2020.

[22] KRUBNIKI, Monique. PEREIRA, Elias. A responsabilidade Civil e Criminal do Profissional de Engenharia Civil. Revista de Engenharia e Tecnologia. Vol. 11, n. 4, Dez. 2019.

[23] LEINFELDER, Robson Rodrigues. Análise de Riscos para Redução dos Riscos de Segurança em uma Pedreira Paulista. Dissertação (Mestrado de Ciências em Engenharia de Minas e Petróleo), Escola Politécnica da Universidade de São Paulo, São Paulo, 2016.

[24] MACEDO, Wesley. Lugares Abandonados. Revista ARA 7 Pyau Horizontes Extremos: Desafios ou Fronteiras. Vol. 7, n. 7, p.153-170, 2019.

[25] MANAUS, Código de Obras e Edificações do Município de. Lei Complementar $\mathrm{N}^{0}$ 3, de 16 de Janeiro de 2014. Disponível em: <https://leismunicipais.com.br/a2/codigo-de-obras-manaus-am>. Acesso em: 13 junho 2020.

[26] MANAUS, Norma Municipal de. Decreto $\mathrm{N}^{0}$ 4705, de 18 de Dezembro de 2019. Disponível em: <https://www.normasbrasil.com.br/norma/decreto-4705-2019-manaus_387642.html>. Acesso em: 13 junho 2020.

[27] MANAUS, Plano Diretor Urbano e Ambiental do Município de. Lei Complementar $\mathrm{N}^{0}$ 2, de 16 de Janeiro de 2014. Disponível em: <https://leismunicipais.com.br/plano-diretor-manaus-am>. Acesso em: 13 junho 2020.

[28] MARINHO, Danilo Lopes Morais. Avaliação de Risco de um Sistema de Proteção Contra Descargas Atmosféricas. Monografia (Bacharel em Engenharia Elétrica - Centro Universitário de Brasília, Faculdade de Tecnologia e Ciências Sociais Aplicadas - FATECS) Brasília, 2018.

[29] MARTINS, Mayra Fernandes et al. Descarte Inadequado de Lixo e seu Impacto no Meio Ambiente e na Saúde da Comunidade. Anais do IV Colóquio Estadual de Pesquisa Multidisciplinar. II Congresso Nacional de Pesquisa Multidisciplinar, 2019.

[30] NETO, Severino. Clientes da Encol ainda esperam. Jornal do Commercio. Manaus, 27 de agosto de 1999. Disponível em: <http://memoria.bn.br/pdf/170054/per170054_1999_37908.pdf> Acesso em: 10 junho 2020.

[31] OLIVEIRA, Thiago Déo. Improbidade administrativa e seus efeitos nos casos de desvio de recursos públicos nas obras inacabadas e contratadas pelo poder público. Monografia (Bacharel em Direito - Centro Universitário Tabosa de Almeida, Universidade particular em Caruaru, Pernambuco), Caruaru, 2016.

[32] PORTUGAL, Marco Antônio. Corrupção em Obras Públicas: Uma análise dos procedimentos licitatórios no papel de combate à corrupção. Dissertação (Mestrado em Administração - Centro Universitário FEI), São Paulo, 2017.

[33] PRANDEL, Jéssica Aparecida et al. Redução de Riscos de Desastre: Métodos e Práticas. Ponta Grossa (PR): Atena Editora, 2019.

[34] SANTOS, Lidiane Rebouças. O impacto das Obras Habitacionais Inacabadas Village Itaipu, nos Imóveis do Jd. São Paulo em Cambé - PR. Bauru: Ciência Geográfica. vol. XXII. n.1, p.141-151, jan./dez. 2018.

[35] SCHMIDT, Stefanie. Prédios abandonados e falta de regulamentação municipal gera descontrole na cobrança do IPTU. 2013. Disponível em: <https://www.acritica.com/channels/manaus/news/predios-abandonados-e-falta-deregulamentacao-municipal-gera-descontrole-na-cobranca-do-iptu> Acesso em: 22 maio 2020.

[36] SOUZA, Glaucia Cunha. A Qualidade do Atendimento ao Público: um estudo de caso no Instituto Municipal de Planejamento Urbano - IMPLURB/Prefeitura Municipal de Manaus. Dissertação (Mestrado em Engenharia da Produção - Universidade Federal do Amazonas), Manaus, 2017.

[37] TCU - Tribunal de Contas da União. Obras Públicas: recomendações básicas para a contratação e fiscalização de obras públicas. 3. ed. Brasília: SecobEdif, 2013. 
